


Dalia Jaqueline Santa Cruz-Vera

Bióloga-microbióloga de la Universidad Pedro Ruiz Gallo, Lambayeque-Perú. Máster en Ciencias del Matrimonio y la Familia por el Instituto Giovanni Paolo II, de la Pontificia Università Lateranense. Máster en Bioética de la Università Sacro Cuore en Roma. Actualmente es docente y coordinadora del área de Ética y Bioética del Departamento de Humanidades de la Universidad Católica de Colombia.djsantacruz@ucatolica.edu.co https://orcid.org/0000-0001-7365-154X la premisa: "el éxito de una misión no está en formularla, sino en vivirla". 


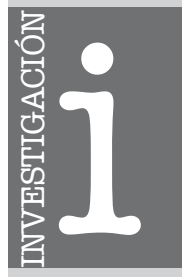

\section{Persona y felicidad \\ Aportes desde la educación, la filosofia, la historia, la ética, la política, el derecho y la bioética}

Dalia Jaqueline Santa Cruz-Vera

(COMPILADORA) 
Martin-Fiorino, Víctor

Persona y felicidad. Aportes desde la educación, la filosofía, la historia, la ética, la política, el derecho y la bioética / Víctor Martin Fiorino y otros catorce: compilado por Dalia Jaqueline Santa Cruz-Vera

212 páginas; $17 \times 24 \mathrm{~cm}$. - (Colección Maestros, no; 5)

ISBN: 978-958-5133-66-2 (impreso)

978-958-5133-67-9 (digital)

I.Título II. Serie III. Ospina-Hernández, Carlos Arturo IV. Cadavid-Claussen, María Victoria V. Ramírez-Orozco, Sandra Ligia VI Nossa-Ramos, Diana Constanza VII. Ferrari- Francesco, VIII Muñoz- Buitrago, Darwin Arturo IX. Guarín-Ramírez, Édgar Antonio X. Romero-Sierra, María Cristina XI. Castaño-Bedoya, Alejandro XII. Reyes-Velandia, Viviana XIII. Camelo-Cárdenas, Lina María XIV. González-Cabrera, Claudia Karolina XV. Rodríguez-Paz, Camila Ivanna XVI. Poveda-Sandoval, Sonia Vanessa XVII. Santa Cruz-Vera, Dalia Jaqueline (comp.)

1. Felicidad 2. Emociones

Dewey 152.42 ed 21

Proceso de arbitraje

$1^{\text {ra }}$ evaluación: 13 de septiembre de 2020

$2^{\mathrm{da}}$ evaluación: 23 de octubre de 2020

( ) Universidad Católica de Colombia

(c) Dalia Jaqueline Santa Cruz-Vera (comp.)

(c) Víctor Martin-Fiorino

- Carlos Arturo Ospina Hernández

- María Victoria Cadavid-Claussen

(0) Sandra Ligia Ramírez-Orozco

- Diana Constanza Nossa-Ramos

(0) Francesco Ferrari

( ) Darwin Arturo Muñoz Buitrago

- Édgar Antonio Guarín-Ramírez

- María Cristina Romero-Sierra

( ) Alejandro Castaño Bedoya

( ) Viviana Reyes Velandia

o Lina María Camelo Cárdenas

- Claudia Karolina González Cabrera

- Camila Ivanna Rodríguez Paz

(c) Sonia Vanessa Poveda Sandoval

\section{Dirección editorial}

Stella Valbuena García

\section{Coordinación editorial}

María Paula Godoy Casasbuenas

Corrección de estilo

Alejandra Muñoz

Diseño de pauta

Juanita Isaza Merchán

\section{Diagramación}

Andrés Mauricio Enciso Betancourt

\section{Publicación digital}

Hipertexto Ltda.

www.hipertexto.com.co
Primera edición, Bogotá, D. C.

Abril de 2021

\section{Impreso}

Santa Cruz-Vera, D. J. (Comp.). (2021). Personay felicidad. Aportes desde la educación, la filosofía, la historia, la ética, la política, el derecho y la bioética. Editorial Universidad Católica de Colombia.

\section{Digital}

Santa Cruz-Vera, D. J. (Comp.). (2021). Persona y felicidad. Aportes desde la educación, la filosofía, la historia, la ética, la política, el derecho y la bioética. Editorial Universidad Católica de Colombia. https://doi.org/10.14718/9789585133679.2021

\section{Departamento de Humanidades \\ Diagonal 47 \# 15-50 \\ Sede El Claustro \\ humanidades@ucatolica.edu.co}

\section{Editorial}

Av. Caracas \# 46-72, piso 5

editorial@ucatolica.edu.co

www.ucatolica.edu.co

Todos los derechos reservados. Esta publicación no puede ser reproducida ni total ni parcialmente o transmitida por un sistema de recuperación de información, en ninguna forma ni por ningún medio, sin el permiso previo del editor.

Hecho el depósito legal

o Derechos reservados

Licencia Creative Commons Atribución-CompartirIgual 4.0 Internacional (CC BY-SA 4.0)

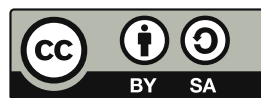




\section{DePARTAMENTO DE HuMANIDAdES}

Grupo de investigación

Philosophia Personae

Línea de investigación Antropología filosófica

Educación, ética y política

Proyecto de investigación

Proyecto integrador. La persona humana y sus manifestaciones 



\section{Resumen}

El libro recoge una colección de artículos producto de investigaciones adelantadas por docentes del Departamento de Humanidades y cuyo centro temático es la relación entre las personas y la felicidad. Cada capítulo brinda respuestas desde un ámbito específico disciplinar, a través de una metodología cualitativa, al problema antropológico y ético de la consecución de la felicidad o la realización humana personal. Desde la educación y la ética se plantea la transición de unas humanidades informativas a otras performativas, que integren formación moral y valores sobrenaturales, que aboguen por la empatía y la solidaridad como camino humano de felicidad. A partir de las claves antropológicas de Leonardo Polo se presenta a la persona como ser capaz de dotar de sentido su modo de estar en el mundo, más allá de la propia satisfacción felicitaria, pues ella misma es un sentido personal capaz de manifestarse en la tarea esperanzada. Así mismo, desde la antropología personalista se estudia la felicidad como proyecto de vida, pasando de la conflictividad hacia la espiritualidad y proponiendo decantadas transformaciones político-educativas. En el ámbito de las ciencias históricas se analiza el uso de los conceptos de persona y felicidad en el Magisterio de Juan XXIII subrayando las perspectivas sugeridas por el Papa y recogidas por los pontífices sucesivos. Desde el derecho se analiza la relación entre justicia y felicidad, aplicada al llamado "derecho a morir dignamente"; y desde la bioética 
se plantean reflexiones sobre procreación y felicidad a partir del debate actual sobre la maternidad subrogada.

Palabras clave: justicia y felicidad, realización personal, derecho a morir dignamente, maternidad subrogada, magisterio pontificio, antropología trascendental, ética y educación. 


\section{Summary}

The book includes a collection of articles resulting from research carried out by teachers of the Department of Humanities and whose thematic center is the relationship between people and happiness. Each chapter provides answers from a specific disciplinary field, through a qualitative methodology, the anthropological and ethical problem of achievement of happiness or personal human fulfillment.

From education and ethics, the transition from some informative humanities to other performative ones is proposed, which integrate moral formation and values that advocate empathy and solidarity as a human path to happiness.

From the anthropological keys of Leonardo Polo, the person can give meaning to their presence in the world, beyond the satisfaction of happiness itself, since human beings has a personal sense capable of manifesting themselves in the hopeful task. Likewise, from the personalistic anthropology, happiness is studied as a life project, moving from the conflict towards spirituality and proposing chose political educational transformations.

In the field of historical sciences, the use of the concepts of person and happiness in the Magisterium of John XXIII underlines the perspectives suggested by the Pope and collected by successive pontiffs. From the law, the relationship is analyzed between justice and happiness, applied to the so-called "right to die 
with dignity"; and from the bioethics, reflections on procreation and happiness are raised based on the current debate on surrogacy.

Keywords: Justice and happiness, personal fulfillment, right to die with dignity, surrogate motherhood, pontifical magisterium, transcendental anthropology, ethics and education. 


\section{Contenido}

Prólogo. Dos tesoros en riesgo ................................................................................ 11

Edwin de Jesús Horta Vásquez

Presentación .15

Víctor Martin Fiorino, Dalia Santa Cruz-Vera

1

Ethos y gracia en la educación de los jóvenes .17

Carlos Arturo Ospina-Hernández

\section{2}

Persona y sentido: la tarea esperanzada más allá de la felicidad. Una propuesta desde la Antropología Trascendental de Leonardo Polo 41 María Victoria Cadavid-Claussen

\section{3}

Felicidad, empatía y solidaridad personal frente al trauma sociocultural de la pandemia en Italia 73

Sandra Ligia Ramírez-Orozco

\section{4}

Persona y felicidad en el Magisterio de Juan XXIII (1958-1963) 97

Francesco Ferrari

\section{5}

Persona, convivencia y felicidad. Condiciones ético-políticas

y educativas para la construcción de la felicidad. 125

Víctor Martin-Fiorino, Darwin Muñoz-Buitrago

\section{6}

Justicia y felicidad: un análisis de su relación desde el denominado "derecho a morir dignamente" 151

Édgar Antonio Guarín Ramírez María Cristina Romero-Sierra 


\section{7}

Felicidad y procreación. Reflexiones sobre la maternidad subrogada y la infertilidad........

Viviana Reyes-Velandia, Lina María Camelo-Cárdenas, Claudia Karolina González-Cabrera, Camila Ivanna Rodríguez-Paz, Sonia Vanessa Poveda-Sandoval, Diana Constanza NossaRamos, Alejandro Castaño-Bedoya 


\section{Prólogo \\ Dos tesoros en riesgo}

EDWIN DE JESÚS HORTA VÁSQUEZ*

Por encargo de la doctora Dalia Santa Cruz-Vera, coordinadora del Área de Ética y Bioética de Humanidades de la Universidad Católica de Colombia, me ha correspondido la honrosa tarea de presentar esta colección de artículos que contienen los resultados de investigaciones adelantadas por profesores de la Unidad Académica de Humanidades de nuestra universidad.

El centro temático de esta producción es la persona humana, que es precisamente también el centro de la misión de la Universidad Católica de Colombia.

Esta publicación no es, estoy seguro, puramente una coincidencia sino el fruto de una tensión entrañable, de una fuerza interior de carácter espiritual que se respira en el ambiente de la universidad y se percibe, también y tal vez con mayor evidencia, desde fuera, a juzgar por los resultados de todos los procesos de evaluación para acreditar en alta calidad sus programas y la institución misma, procesos adelantados por la universidad ante los respectivos pares académicos designados por el Gobierno nacional; evaluaciones en las cuales nuestra misión siempre ha ocupado un lugar de primera fila y ha sido reconocida expresamente por autoridades académicas tanto nacionales como internacionales. No es tampoco un esfuerzo solo de unas pocas personas, es más bien el producto de un miramiento amoroso por parte de la providencia a un puñado de intelectuales

\footnotetext{
* Vicerrector Jurídico de la Universidad Católica de Colombia.
} 
que se han "arriesgado" a proclamar al mundo que la realidad de Dios no es ajena ni puede excluirse de ser estudiada por la razón humana, con el rigor intelectual que debe cruzar todos los campos del conocimiento, sobre todo el de la educación superior.

El conocimiento científico se va desplazando cada vez con más fuerza hacia las franjas del dato técnico y el dato útil, paralelamente se observa una especie de engrosamiento de lo humano del hombre y un consecuente debilitamiento de su ser personal. Es por ello que en nuestra cultura actual no es difícil apreciar una especie de espejismo sobre la persona; el impacto de ese fenómeno es el oscurecimiento de la realidad personal como dueña y responsable por sí y de sí misma, desplazándola a lo puramente humano en tanto biológico y sensible, mientras se le absolutiza la libertad, como si esta fuera el fundamento de toda realidad y cuya legitimidad de ejercicio solo le será reconocida si dicha libertad, y solo si, se encuentra en el marco de lo políticamente establecido.

En las condiciones descritas la posibilidad de felicidad ni siquiera llega a ser tal, y es precisamente por ello que la obra de nuestros profesores constituye un verdadero planteamiento para la ciencia y la intelectualidad de hoy.

Las investigaciones del presente libro plantean interrogantes sobre la persona y la felicidad, cuestiones que son verdaderas columnas de fundamentación de la existencia humana y en torno a ellas se recorren distintas perspectivas sobre el bien moral y la beatitud. Sobre el sí mismo en tanto expectante de lo trascendente en el contexto del profesor polo. Sobre los sentimientos humanos del cariño y la empatía de quien comparte la misma realidad con quien sufre o se alegra. Por la vía de la doctrina católica una exposición en el marco de la antropología del Concilio Vaticano Segundo, hasta llegar a proponer de una manera decantada y ya madura, que las propuestas acerca de la persona humana y la felicidad exigen la revisión de nuestras actuales condiciones políticas y educativas.

Cuestiones realmente difíciles, pero que son a la vez una convocatoria necesaria para los pensadores de la humanidad. Convocatoria necesaria porque al mundo de hoy parece interesarle poco y muy poco saber de la vida espiritual. Y difícil, 
porque el sustituto a la felicidad que se le ofrece a la convaleciente espiritualidad humana de hoy parece estar circunscrita al mundo de lo político y métricamente administrada por las legislaciones que van desde el aborto hasta la eutanasia; temas estos últimos que también están desarrollados responsablemente y sobre fundamentos, pruebas y argumentos a disposición de las razones, objeciones y consideraciones del lector.

Instituciones tales como la educación, la familia, la autoridad, la paz, el perdón, la justicia, el bien, la verdad, los hijos, la vida, la muerte, la paternidad, la maternidad, la belleza y el orden son todas ellas predicables exclusivamente de la persona humana que reclaman hoy su significado y espacio real en el mundo de la interioridad y la intimidad de la persona que las contiene y que enmarcan su felicidad.

Invito a los autores de la obra a continuar avanzando en la restauración de estas realidades espirituales sobre estatutos epistemológicos rigurosos, como lo han hecho hasta hoy, pues constituyen expresiones de la libertad humana y de todas ellas pende la felicidad.

Los lectores les agradecerán; sus contradictores se interrogarán. Dios estará feliz porque su tesoro más preciado es la persona humana y la felicidad de ella su mayor deseo. 



\title{
Presentación
}

\author{
VÍctor Martin FIORINO* \\ Dalia Santa CRUZ-Vera**
}

Este libro es producto del trabajo académico de un grupo de docentes e investigadores del Departamento de Humanidades, vinculados a las líneas Antropología Filosófica y Ética, Educación y Política del grupo de investigación Philosophia Personae, actualmente reconocido en Colciencias.

El macroproyecto de investigación La persona humana y sus manifestaciones es el punto de partida de los resultados que se reúnen en el presente texto bajo el título: Persona y felicidad. Aportes desde la educación, la filosofía, la historia, la ética, la política, el derecho y la bioética. Cada capítulo busca dar respuesta, desde un específico ámbito disciplinar, y a través de una metodología cualitativa, documental, hermenéutica y crítica, al problema antropológico y ético de la consecución de la felicidad o realización humana personal.

La pregunta general de investigación que dirigió estos aportes fue la de la relación entre persona y felicidad, vista desde las múltiples dimensiones de la realidad humana personal: icómo poder ser felices en sociedades marcadas por la falta de hospitalidad, por una "tecnología sin alma" y por el poder, en que la persona no es visible o es considerada un simple producto cultural?

* Director del grupo de investigación Philosophia Personae.

** Coordinadora del Área de Ética y Bioética, compiladora de publicaciones del Departamento de Humanidades de la Universidad Católica de Colombia 
Se les pidió a los autores que en la introducción de cada capítulo señalaran el problema y los objetivos de su investigación, en relación directa con el tema común: persona humana y felicidad. Que indicaran, así mismo, las principales fuentes, autores o corrientes filosóficas desde las que partiría su investigación, la metodología específica a desarrollar y el ámbito de la vida humana al que contribuiría, de manera significativa, los resultados obtenidos.

En su conjunto, de modo articulado y coherente, cada artículo, analiza en profundidad las diferentes causas en torno a las cuales gira, hoy por hoy, la felicidad y la realización humana personal.

De ahí que el presente libro se constituya en un valioso aporte a las diferentes áreas del conocimiento: la educación (Ethos y gracia en la educación de los jóvenes); la historia de la Iglesia (Persona y felicidad en el magisterio de Juan XXIII); la antropología filosófica (Persona y sentido: la tarea esperanzada más allá de la felicidad. Una propuesta desde la antropología de Leonardo Polo); la ética (Felicidad, empatía y solidaridad personal frente al trauma sociocultural de la pandemia); la política (Persona, convivencia y felicidad. Condiciones ético-políticas y educativas para la construcción de felicidad); el derecho (Justicia y felicidad: un análisis de su relación desde el denominado "derecho a morir dignamente"), y la bioética (Felicidad y procreación. Reflexiones sobre la maternidad subrogada y la infertilidad).

Las cuestiones planteadas profundizan en los ámbitos descritos, toman posición y aportan argumentos para su análisis, dejando abiertas perspectivas de investigación para ahondar en los temas tratados. 


\section{1 \\ Ethos y gracia en la educación de los jóvenes}

Carlos Arturo Ospina-HernÁNDeZ*

\section{Resumen}

El presente escrito se centra en el concepto de ethos como el aspecto central que le da sentido y contenido al compromiso de la educación y en especial la educación católica, en la medida en que dicho concepto gira en torno a la experiencia compartida que le da contenido al concepto de encuentro. En la base del ethos cristiano se encuentra la experiencia del encuentro, sobre la cual se construye el cristianismo como encuentro con Cristo y donde halla un lugar importante el concepto de gracia. De ese encuentro inicial deriva el encuentro interhumano que tiene lugar en la educación, centrado en la construcción de un nosotros sobre el cual se asienta la experiencia educativa que, en el caso de la educación católica, recoge el desafío de la espiritualidad y de la integralidad de la formación humana. Este trabajo es derivado de los resultados de la investigación Relación entre capital psicológico y capital ético aplicado a los valores corporativos de la Universidad Católica de Colombia (Ospina Hernández y Delgado Abella, 2019).

Palabras clave: ética, conciencia, educación, gracia, jóvenes.

\footnotetext{
* Docente investigador y subdirector del Departamento de Humanidades de la Universidad Católica de Colombia, miembro de número de la Academia de Historia Eclesiástica de Bogotá y de la Academia Caldense de Historia. caospina@ucatolica.edu.co https://orcid.org/0000-0002-8578-5227
} 


\section{Introducción}

Para abordar el tema del ethos desde la doctrina social católica es necesario destacar que esta apunta a una interacción ética entre la conciencia y el intelecto, de la que puede resultar un desarrollo realmente humano de la persona, con la fuerza del amor y de la gracia que vence al mal con el bien y abre la conciencia del ser humano a relaciones recíprocas de libertad y responsabilidad.

En esa línea, el Instrumentum Laboris del Sínodo sobre la Juventud (2018) plantea la necesidad de una sólida formación ética y espiritual de los jóvenes, de lo cual se desprende que les corresponde a las instituciones educativas asumir un compromiso con ese postulado y orientar una ética capaz de abrir las mentes de los jóvenes al papel de la gracia. En el centro de este compromiso está la labor de unir a los postulados de la recta razón, el reconocimiento de la actuación de Dios en la humanidad, para, de ese modo, llevar a cabo el plan divino que conduce a la posibilidad y a la realización de una convivencia al servicio de la civilización del amor.

El propósito del presente trabajo es promover un nuevo horizonte en el proceso educativo de las universidades católicas, destinado a reivindicar el compromiso socialmente radical de las bienaventuranzas en dirección a una fe robusta, un generoso desprendimiento, una mansedumbre a toda prueba, un alma pacífica y misericordiosa, aunados a una sed y un hambre de justicia, que contribuyan eficazmente al trinomio persona, compasión y felicidad. Para ello, el camino escogido es el de una investigación hermenéutica sobre los conceptos y el contenido vivencial del ethos y la gracia.

El resultado que se busca es el de fundamentar el tránsito por un camino que va desde unas humanidades informativas hacia unas humanidades realmente performativas, capaces de educar a una persona cuya vida esté centrada en la compasión y la felicidad iluminadas, en un recorrido de plenitud, por el ethos y la gracia, como instancias que se constituyen en referentes para la educación católica concebida como experiencia de encuentro. 


\section{La evolución de la ética y la ética sin Dios}

En su obra Jesús de Nazareth (2018), el papa emérito Benedicto XVI, al analizar la parábola del fariseo y el publicano, enseñaba cómo el uno encarna la mentalidad ethos y el otro, a través del arrepentimiento y la apertura a la salvación, la mentalidad gracia; el uno tiene en cuenta la ley y su ególatra observancia, el otro a Dios, el perdón y la misericordia, derivadas en una verdadera y sólida ética, construida sobre verdad del amor y la compasión para con el prójimo.

Esta premisa resulta verdaderamente importante frente a los pensadores que proponen una ética sin Dios. Más allá de las características y limitaciones que pueden señalarse en las diferentes elaboraciones racionalistas de la ética que, situadas en la tradición del Iluminismo, excluyen toda referencia a Dios, o en las éticas que se construyen "etsi Deus non daretur", "como si Dios no existiese", según ya lo expresaba Hugo Grocio en el siglo XVII. Hay que señalar que estas elaboraciones desembocan en no pocas contradicciones que afectan al concepto mismo de la ética, tal como sucede en las derivaciones del subjetivismo ético y del utilitarismo, según lo expresado de modo claro en la crítica de Karol Wojtyla al enfoque utilitarista (Wojtyla, 2008).

Aunque en buena medida la evolución de la ética está signada por la centralidad del concepto de justicia, que el pensamiento filosófico clásico de Platón y Aristóteles colocaba en su base (Macintyre, 1994; Garcés y Giraldo, 2014), el cristianismo introdujo, desde sus inicios, el amor y la compasión como base del comportamiento moral, marcando con ello una inflexión decisiva. Ello ha sido recogido en la historia del pensamiento filosófico y teológico cristiano y en la doctrina social de la Iglesia y resumido en importantes documentos sobre las bases de la moral cristiana (Comisión Teológica Internacional, 1988). Sus repercusiones en el campo de los compromisos de la educación católica son sin duda de gran importancia.

Sin entrar en esta sede, en el amplio debate contemporáneo sobre las consecuencias de una ética sin Dios, cabe mencionar que, en muchas de sus expresiones, 
esta es conducida a ser una expresión ideológica o un juicio subjetivo sobre la acción humana, lo que termina por reducir la norma moral a ser la expresión de determinados condicionamientos sociales o bien de emociones y sentimientos en relación con los problemas de la convivencia.

En el contexto de la educación católica, el Instrumentum Laboris del Sínodo sobre la Juventud (2018) planteaba el problema de una ética y una espiritualidad sólidas en la formación de los jóvenes, cuyos resultados son decisivos para caracterizar la noción de encuentro, en sus bases como encuentro con Cristo y en sus implicaciones para la construcción de un "nosotros" capaz de darle profundidad al ethos educativo abierto a su finalidad de promover la unión y la fraternidad entre los hombres.

En tal sentido, san Agustín de Hipona describía los frutos de esa educación en el orden temporal: "iImaginemos un ejército constituido por soldados como los forma la doctrina de Jesucristo: gobernadores, maridos, esposas, padres, hijos, maestros, siervos, reyes, jueces, contribuyentes, cobradores de impuestos como los quiere la doctrina cristiana!" (De Hipona, 1913, p. 15). Por otra parte, en relación con el papel de la Iglesia hace el siguiente elogio de la misma: "Unís no solo en sociedad, sino en especie de fraternidad, los ciudadanos a las ciudadanas, las naciones a las naciones, y los hombres entre sí, por el recuerdo de sus primeros padres" (De Moribus Ecclesiae, como se citó en Wolin, 2004, p. 118).

\section{La comprensión de la gracia desde una hermenéutica de la obra de arte}

La hermenéutica de las obras de arte puede abrir valiosas vías de enriquecimiento y comprensión del sentido de la gracia, procedimiento con el cual es posible igualmente iluminar aspectos importantes a tener en cuenta en una educación centrada en el desarrollo de la espiritualidad de los jóvenes. Cabe, en tal sentido, realizar una aproximación hermenéutica al cuadro de La anunciación de Fra Angélico, que reposa en el Museo de El Prado de Madrid (2020). Esta composición representa la escena del arcángel san Gabriel saludando a la Virgen María 
con las palabras narradas en el Evangelio de san Lucas: "iAlégrate, llena eres de gracia, el Señor está contigo!” (Lucas 1: 28). El cuadro también representa en el lado izquierdo la escena de Adán y Eva siendo expulsados del Paraíso y un ángel, encargado de custodiarlo con una espada de fuego, para que no puedan volver a entrar en tan maravilloso lugar.

Las dos escenas que Fra Angélico presenta al espectador representan la caída y la redención, las figuras de la serpiente victoriosa y la serpiente aplastada pueden ser vistas en una lectura que integra historia y mensaje, como las del engaño asumido por Adán y Eva, quienes obraron en desobediencia y desamor, que los lleva hacia la expulsión, la vergüenza y la tristeza de una humanidad destinada al pecado, la enfermedad y la muerte.

La hermenéutica de la obra de arte contribuye a reforzar la convergencia de perspectivas estéticas y éticas que permiten acercarse a la riqueza del acto de aceptación humana de la voluntad divina, desde la humildad, el reconocimiento de la propia limitación y la reconstrucción de la confianza que puede abrir a lo que está más allá del entendimiento humano y que escapa a su comprensión. Todo ello tiene importantes consecuencias para una educación que apunte al desarrollo de una espiritualidad dadora de sentido y, así centro del proyecto educativo rehumanizador.

El contenido de la Escritura representado en el cuadro de Fra Angélico indica que la redención es asumida con alegría y plenitud de la gracia por la Virgen María, que, no pretendiendo ser como Dios, se siente perturbaba en su humildad y en su amor por la declaración del ángel. Este, según el texto de san Lucas, la tranquiliza diciéndole: "No temas María, porque has hallado gracia delante de Dios" (Lucas, l: 30). Para luego transmitirle el gran anuncio:

Concebirás y darás a luz un hijo, a quien pondrás el nombre de Jesús. Él será grande, será llamado hijo del altísimo, y el Señor Dios le dará el trono de su hijo David. Él reinará para siempre sobre los descendientes de Jacob, y su reino no tendrá fin. (Lucas l: 31-33) 
En la fuerza expresiva de la pintura es posible ver a María que, ratificando su virginidad, su humildad y su obediente disposición ante la voluntad divina, pregunta: “¿Cómo ocurrirá, si yo no conozco varón?” (Lucas l: 34). El ángel le respondió:

El Espíritu Santo vendrá sobre ti y el poder del Altísimo te cubrirá con su sombra; por eso el que ha de nacer será santo y se le llamará Hijo de Dios. Mira, también Isabel, tu pariente, ha concebido un hijo en su vejez y este es ya el sexto mes de la que se decía que era estéril, porque no hay nada imposible para Dios.

La respuesta de María: "He aquí la esclava del Señor; hágase en mí según tu palabra" es el signo de la gracia de Dios.

En la composición pictórica, el fiat de María, análogo al de Dios Padre cuando crea el universo, da origen a la encarnación del verbo. Fra Angélico lo representa en un potente y dorado rayo de luz, que se desprende del ángulo superior izquierdo del cuadro con las manos de Dios Padre, en una inclinación diagonal que alberga en sus haces finales al Divino Espíritu Santo, representado por una paloma, para finalmente llegar hasta María, quien ha generado un octavo día de la creación, volviendo a unir el cielo con la tierra al entregar su amor, su carne y su sangre al Verbo Eterno y Encarnado.

El resultado de la fuerza expresiva de la composición es una gran escena de reconciliación de Dios con la humanidad y de la humanidad con Dios. La tragedia del pecado, la enfermedad y la muerte, representada a la izquierda del cuadro, es superada por la plenitud de la alegría, el amor y la vida que ha prodigado a la humanidad la llena de gracia. Gracia que ha dado origen al octavo día de la creación con la encarnación de Dios en María, como persona humana y divina al mismo tiempo.

Otros detalles no menos significativos aparecen en la pintura: el intercambio de miradas entre san Gabriel y la Virgen, que evocan la pureza de las aguas cristalinas y la apacible y luminosa presencia de Dios en sus espíritus sin mancha. El gesto de sus manos abrazadas en el pecho, como signo de su unión con la divinidad, la guarda del corazón y su pureza espiritual embebida de la presencia de Dios. Sus trajes encarnados en su tonalidad, adornados con franjas doradas, el manto 
azul lapislázuli de la Virgen forrado de verdor. La figura de Dios Padre esculpida en el dintel de los arcos, el interior austero de la habitación que se vislumbra adentro.

Todo se conjuga armónicamente con la grandeza de la escena originada en la humildad de una creatura liberada del determinismo de la naturaleza desordenada, por quienes estaban destinados a enseñorearla, dada su dignidad espiritual de creaturas hechas a imagen y semejanza de Dios. María, exenta de toda culpa y siempre menesterosa de la divinidad, enseñoreada de la naturaleza, logra reconciliarla con el Creador mediante el prodigio de la encarnación.

Su manto azul es el cielo; el forro de su manto, la naturaleza; el libro que reposa en la rodilla derecha de la Virgen, por su parte, contiene el texto bíblico en los caracteres hebreos de la profecía de Isaías: "una virgen dará a luz". Dando un sentido de totalidad a la representación pictórica, el sello del Padre Eterno entre los arcos le confiere un aire palaciego a la escena, todo lo cual, junto a la figura de la golondrina posada en lo alto de la columna, reitera esa reconciliación entre el Creador y la naturaleza.

\section{Hermenéutica estética, inteligencia y gracia: repercusiones para la educación}

En el marco del pensamiento acerca de una educación católica que integre todas las dimensiones de la persona en un aprendizaje rehumanizador que arranca desde la razón abierta a la trascendencia y conduce, a través del ejercicio del amor y la compasión, a la plenitud de la verdadera felicidad, es valioso destacar los aportes de quienes, como Fra Angélico, representan magistralmente el mensaje cristiano de la reconciliación.

Guidorino di Pietro da Mugello, era el nombre secular de Fra Angélico, fraile dominico que realizó La anunciación en oro y temple sobre tabla, con colores elaborados a partir de piedras preciosas, pintándola a lo largo de diez años, entre 1425 y 1436. 
Acerca del valor de su arte, el pensador católico Plinio Correa de Oliveira afirmaba que Fra Angélico fue a la pintura lo que Santo Tomás de Aquino a la teología (Correa de Oliveira, 2005). Por su parte, Miguel Ángel, según lo refiere Dubreton (1961), comentaba de las obras de arte de Fra Angélico que parecía que le dieran permiso de entrar en el Paraíso para realizar sus pinturas.

Realmente a Fra Angélico siempre se le designó como el beato Angélico con mucha antecedencia a su beatificación, que fue decretada por Juan Pablo II en 1982. Giorgio Vasari, por su parte, en su libro Vida de los mejores, pintores, escultores y arquitectos, se refiere a él como Fra Giovanni Angélico, poseedor de un "raro y perfecto talento" y menciona que "nunca levantó el pincel sin decir una oración ni pintó el crucifijo sin que las lágrimas resbalaran por sus mejillas" (Vasari, 1550). Esto significa que supo convertir cada pincelada en una oración y logró transmitir una visión beatífica en cada una de sus obras, donde la levedad de sus personajes los hace ver como exonerados de la ley de la gravedad, exentos de caer y dirigidos a elevarse.

Todos concuerdan en que la Anunciación fue el punto de encuentro entre el Antiguo y el Nuevo Testamento. El momento en que la llena de gracia pronuncia el "hágase" que significó el Dios hecho hombre análogo al hágase de Dios en la creación del universo y del hombre.

Se hace evidente así en la historia de la humanidad la era de la redención mediante la cual, por obra de la gracia de Dios, se rescata la naturaleza caída. En tal sentido, cabe afirmar que en la hermenéutica de la obra de Fra Angélico vemos representada la gracia en todo su esplendor.

Para responder a la pregunta iqué es la gracia? Y avanzar en la reflexión sobre sus repercusiones en la educación, cabe referir que, en su obra Revolución y contrarevolución, Correa de Oliveira (1978) afirma:

El papel de la gracia consiste exactamente en iluminar la inteligencia, en robustecer la voluntad y en templar la sensibilidad de manera que se vuelvan hacia el bien. De suerte que el alma lucra inconmensurablemente con la vida sobrenatural, que la eleva por encima de las miserias de la naturaleza caída y del propio nivel de la naturaleza humana. (p. 112) 
En relación con la capacidad de la gracia de permitir al hombre elevarse por encima del nivel de lo humano y reconciliarse con el Creador, las Sagradas Escrituras hacen referencia a ella como un don de origen divino, lo que en el Nuevo Testamento alcanza una idea más plena entendiéndola como vida sobrenatural, participación creada de la vida increada de Dios, irradiación permanente del misterio de la encarnación en el escenario donde se ha operado el misterio de la redención. Como bien lo enseña san Pablo:

[...] cuando alguno sin hacer las obras exteriores o de la ley, con creer a aquel que justifica al impío, se le reputa su fe por justicia; es este un don gratuito, según el beneplácito de la gracia de Dios. (Romanos 4: 5)

Según san Agustín, como consecuencia del pecado original, el hombre, dada su inclinación al mal, puede pecar en algún momento de su vida. En estas consideraciones recuerda la Epístola de san Pablo a los Romanos: "Por cuanto no hago el bien que quiero; antes bien hago el mal que no quiero" (Romanos 7: 19). Piensa san Agustín que, sin el auxilio de la gracia, se cae en el pecado (San Agustín, 1913). También que la gracia es obra del Espíritu Santo (San Agustín, 1981). El misterio del encuentro del amor de Dios y el obrar humano origina un modelo relacional de una gran riqueza antropológica, que eleva la dignidad humana, al reconocer la condición del hombre como ser capaz de un nosotros con Dios, gracias al pleno ejercicio de su libertad, que lo hace capaz de un fiat análogo al de la Virgen María en el momento de la encarnación. Como bien lo dice san Pablo: "Porque el Señor es Espíritu y donde está el Espíritu del Señor, allí hay libertad" (2. e Corintios 3: 17).

Según el modo en que se realiza la gracia en los hombres, si bien el bautizado padece las consecuencias del pecado original, goza en esta vida de la gracia de Dios, con lo cual se robustece la esperanza de la vida eterna, donde se verá cara a cara con Dios y le será imposible pecar. Como camino para ello, la Iglesia comunica la gracia de Dios mediante la oración, los sacramentos y el obrar conforme a los mandamientos. 
El Concilio de Trento (López de Ayala, 1847, pp. XIII-XIV) dice que los pecadores están dispuestos a ser justificados, cuando, movidos y auxiliados por la gracia, creen en la palabra divina, se vuelven libremente a Dios, creen en la verdad de la revelación y lo que ha prometido y son justificados por la gracia que Dios obtenida por la redención de Jesucristo, y reconociéndose pecadores, temerosos de la justicia divina, recurren a la misericordia, se abren a la esperanza y confían en el favor de Dios obtenido por Jesucristo, comenzando a amarle como fuente de toda justicia.

Acerca de la gracia, por otra parte, la declaración conjunta entre católicos y luteranos de 1999 sobre la doctrina de la justificación, en la sección 38 a 43 afirma:

Según la interpretación católica, las buenas obras, posibilitadas por obra y gracia del Espíritu Santo, contribuyen a crecer en gracia para que la justicia de Dios sea preservada y se ahonde la comunión en Cristo. Cuando los católicos afirman el carácter "meritorio" de las buenas obras, por ello entienden que, conforme al testimonio bíblico, se les promete una recompensa en el cielo. Su intención no es cuestionar la índole de esas obras en cuanto don, ni mucho menos negar que la justificación siempre es un don inmerecido de la gracia, sino poner el énfasis en la responsabilidad del ser humano por sus actos.

Continúa el texto de la declaración indicando igualmente que:

Los luteranos también sustentan el concepto de preservar la gracia y de crecer en gracia y fe, haciendo hincapié en que la justicia en cuanto ser aceptado por Dios y compartir la justicia de Cristo es siempre completa. Asimismo, declaran que puede haber crecimiento por su incidencia en la vida cristiana. Cuando consideran que las buenas obras del cristiano son frutos y señales de la justificación y no de los propios "méritos", también entienden por ello que, conforme al Nuevo Testamento, la vida eterna es una "recompensa" inmerecida en el sentido del cumplimiento de la promesa de Dios al creyente.

Resaltando los puntos concordantes, el texto afirma que:

Nuestro consenso respecto a los postulados fundamentales de la doctrina de la justificación debe llegar a influir en la vida y el magisterio de nuestras iglesias. Allí se comprobará. Al respecto, subsisten cuestiones de mayor o menor importancia que requieren ulterior aclaración, entre ellas, temas tales como: La relación entre la Palabra de Dios y la doctrina de la iglesia, eclesiología, autoridad en la iglesia, ministerio, los sacramentos y la relación entre justificación y ética social. Estamos convencidos de que el consenso que hemos alcanzado sienta sólidas bases para esta aclaración. Las iglesias luteranas y la 
Iglesia Católica Romana seguirán bregando juntas por profundizar esta interpretación común de la justificación y hacerla fructificar en la vida y el magisterio de las iglesias. (Curia Pontificial Romana, 1999, pp. 6-7)

Esa declaración confirma el papel de la gracia de Dios en las buenas obras y el sentido del mérito para quienes las practican en esta vida y en la otra, al igual que el reconocimiento de que en Cristo está la justificación. En el consenso logrado, sin embargo, quedó pendiente el tema de la relación entre justificación y ética social, que el catolicismo enfoca desde el compromiso radicalmente social y cristológico expresado en las bienaventuranzas.

\section{Aportes de la Iglesia católica a la formación ética y de la gracia}

El Catecismo de la Iglesia católica compendio (Iglesia Católica, 2005) define en el numeral 422 la justificación de que es "la obra más excelente del amor de Dios"; "que borra nuestros pecados"; "nos hace justos y santos"; "por medio de la gracia del Espíritu Santo"; "que la pasión de Cristo nos ha merecido y se nos ha dado en el bautismo"; "con la justificación comienza la libre respuesta del hombre, esto es, la fe en Cristo y la colaboración con la gracia del Espíritu Santo". Y acto seguido, en el numeral 423, la gracia se justifica como "don gratuito de Dios"; "que nos hace partícipes de su vida trinitaria y capaces de obrar por amor a Él”; "deificante porque nos santifica y nos diviniza"; "sobrenatural porque depende enteramente de la iniciativa gratuita de Dios"; "supera la capacidad de la inteligencia y de las fuerzas del hombre"; "escapa a nuestra experiencia”.

Por otra parte, en el numeral 424 enseña qué tipos de gracia existen: además de la habitual, actuales, sacramentales, especiales o carismas, entre ellas "las gracias de estado, que acompañan al ejercicio de los ministerios eclesiales y de las responsabilidades de la vida". En el numeral 425 responde a la relación que hay entre la gracia y la libertad del hombre, afirmando que "la gracia previene, prepara y suscita la libre respuesta del hombre, responde a las profundas aspiraciones de la libertad humana, la invita a cooperar y la conduce a la perfección". En el numeral 
426 dice que el "mérito es lo que da derecho a la recompensa por una obra buena"; "mediante la unión a la caridad de Cristo, fuente de nuestros méritos ante Dios"; "deben ser atribuidos primero a la gracia de Dios y después a la libre voluntad del hombre". En el numeral 427 se ocupa de la pregunta por los bienes que podemos merecer que son "las gracias útiles para santificarnos, la gloria eterna, bienes temporales según el designio de Dios"; "nadie puede merecer la primera gracia que está en el origen de la conversión y la justificación”.

Stein (2002), en su ensayo sobre La naturaleza, la gracia y la libertad, explica desde la fenomenología cómo se da el señorío de las almas, cuando gozan de la libertad propia de los hijos de Dios, se abren a la acción de la gracia y no permiten que los impulsos naturales los dominen y les impidan el ejercicio de su vocación al amor: “... el espíritu de la luz, el Espíritu Santo, obra en el alma de la que toma posesión una transformación de sus reacciones naturales” (Stein, 2002, p. 82).

En relación con un ethos sin Dios, ello deja en evidencia el grave engaño del moralismo que pretende que el hombre se rija por comportamientos según los dictámenes de la naturaleza desordenada, en lugar de liberarse de ella mediante la gracia y la unión amorosa con Dios para someter esa naturaleza a la voluntad de su creador. Se presenta aquí la indicación acerca de cómo debe darse la superación de la tensión entre el ethos moralista y la gracia vivificante, llamada a renovar la faz de la tierra y el rostro de la humanidad. Las consecuencias de ello llevan a destacar el compromiso de una educación católica, más allá de los meros formalismos moralistas cerrados al papel vivificador de la gracia.

A Dios no le interesa el comportamiento sino el corazón, donde reside toda la realidad humana. Jesús enseña una conversión radical del corazón y unidos a Él vivimos en presencia del Creador y somos hijos de Dios. Sobre ello expresa Stein que:

hay actos espirituales y estados anímicos que son las formas específicas de su vida en cada momento: amor, misericordia, perdón, beatitud, paz... El espíritu de la luz es por su esencia propia plenitud rebosante, riqueza perfectísima que nunca mengua... De hecho, es indudable que en el "renacimiento" su individualidad no es expulsada por el espíritu de la luz, sino que se desposa con él y de ese modo experimenta verdaderamente un 'nuevo nacimiento'. (Stein, 2002, pp. 83-84) 
En el libro de Job (Biblia de Jerusalén, 2020), Dios se refiere a los nacientes astros que lo adoraban o hijos de Dios que conformaban el universo angélico. En este sentido, quien asume esta categoría, al igual que el ángel, hace de su voluntad una con la de Dios, que es la libertad misma porque está liberado de la esclavitud de los impulsos naturales. Mira el universo desde los ojos del Creador y en Él lo reconoce y lo ama sin dejarse arrastrar por su egoísmo, o lo que es peor por el odio o el olvido de aquello que debe ser amado.

El cultivo de la persona, que tiene uno de sus espacios privilegiados en el encuentro educativo, está regido por la libertad humana. En tal sentido, el mejor servicio que podemos hacer a Dios es no oponernos a su gracia, así el espíritu obrará libremente en dirección al bien con entera disponibilidad. La gran tragedia del alma humana es el obrar con oposición o rechazo a la gracia (Meis, 2014). Por su parte, según lo señala Stein (2002):

La esfera de la libertad es, en consecuencia, la libertad misma en la que nos acogemos y en la que somos movidos por la graciosa libertad de Dios; y "cuando la inunda el alma, esta se llena con lo que le es enteramente adecuado y con lo único que le es adecuado". (p. 39)

Stein, además, introduce la libertad entre el reino de la naturaleza y el de la gracia (Bello, 2013). El alma humana opta por uno o por otro y con esta elección se une o rechaza la voluntad de Dios cambiándola por un fruto envenenado. De acuerdo con el sacrificio o la conservación de su libertad que le permita afirmarse como lo que en realidad es: hijo de Dios (Medina Delgadillo, 2019), o pseudodios, la persona marcará su vida en función de un ethos sin la gracia o una gracia que lo ordenará desde el amor a un verdadero ethos donde reinan el servicio, la compasión y la felicidad. Esta articulación es la que da sentido a la educación basada en los principios de la doctrina social de la Iglesia católica, como camino para llegar a ser plenamente persona.

\section{Del ethos sin la gracia al ethos cristiano: la tarea educativa}

En la realidad de un mundo secularizado, con visiones de rechazo a toda relación de la conducta moral con sus fundamentos religiosos, para un análisis de la con- 
cepción de un ethos sin la gracia es interesante tomar en consideración la hermenéutica de Benedicto XVI sobre la parábola del publicano y el fariseo (Benedicto XVI, 2007, pp. 88-89), mencionada al comienzo del presente trabajo.

Al explicar cómo el reino de Dios es Jesús de Nazareth en quien actúa y reina mediante el amor que "llega hasta el extremo" (Juan 13: 1), hasta la cruz, dice que se aclara la tensión entre ethos y gracia al dar el paso de un extremo personalismo al llamado a una nueva familia. Al reflexionar sobre las bienaventuranzas, se puede ver cómo se unen la libertad de la ley, el don de la gracia, la "mayor justicia" exigida por Jesús a los discípulos y la "sobreabundancia" de justicia, frente a la de los fariseos y los escribas (Mateo 5: 20). En tal sentido, examina cómo el fariseo y el publicano oran en el templo de modo diferente (Lucas 18: 9-14).

El fariseo se alaba a sí mismo y cree alabar a Dios. El publicano se reconoce pecador y sin ocultar su culpa pide gracia: se trata de dos maneras de estar delante de Dios y de sí mismo. El uno esta prendado de sus obras, más que de una relación con Dios. El otro está claramente relacionado con Dios, tiene necesidad de Él y de la bondad, pide misericordia y esto lo hará misericordioso como Dios. Necesita del perdón y estará en condición de otorgarlo a los otros. La gracia que pide no lo exime del ethos, pero sí lo capacita para hacer el bien. No niega el ethos, lo libera de la estrechez del moralismo y lo orienta a una relación amorosa, la relación con Dios.

Benedicto XVI también ha afirmado que los santos son los verdaderos intérpretes de la Sagrada Escritura porque la han puesto en práctica en su vida (Benedicto XVI, 2007, p. 106), Refiriéndose a san Juan Pablo II, Benedicto XVI (2020), en la Carta al Episcopado Polaco, formula apreciaciones de las que se puede deducir que el ethos y la gracia se conjugan en la proclamación de la misericordia, centro de "la unidad interna del mensaje de Juan Pablo II y las intenciones fundamentales del papa Francisco". También considera que:

Contra lo que a veces oímos, Juan Pablo II no es un rigorista en moral. Al mostrar la importancia esencial de la misericordia de Dios nos da la oportunidad de aceptar las exigencias morales que se imponen a las personas, aunque el hombre nunca pueda 
cumplirlas plenamente. Nuestros esfuerzos morales se hacen a la luz de la misericordia de Dios, que resulta ser un poder curativo para nuestra debilidad. (Benedicto XVI, 2020)

Con referencia al título de "magno" reconocido por muchos a san Juan Pablo II, comenta que "la palabra 'santo' indica la esfera de Dios y la palabra 'magno', la dimensión humana”. La Iglesia reconoce la santidad por las virtudes heroicas de una persona y el milagro de Dios. Ambos criterios están estrechamente vinculados.

Porque la noción de "virtud heroica" no significa una hazaña olímpica, sino que en y a través de una persona se hace visible algo que no tiene su fuente en ella, sino que es lo que la acción de Dios revela en y a través de ella. No se trata de una competencia moral, sino de renunciar a la propia grandeza. Se trata de que el hombre permita a Dios actuar dentro de sí mismo y así hacer visible la acción y el poder de Dios a través de él. (Benedicto XVI, 2020)

El comentario hizo memoria, por otra parte, de que los dos papas llamados "Magno", León I (s. v) y Gregorio I (ss. VI-VII), salvaron a Roma, no con la fuerza de las armas sino con la fe y la persuasión, de dos ejércitos que amenazaban asolarla: el de Atila, el primero, y el de los lombardos, el segundo. La fuerza de Dios se manifestó también en Juan Pablo II en 1989, con el derrumbe del comunismo en Europa: "no hay duda de que la fe del Papa fue un elemento importante".

Sobre el hecho de que le sea concedido o no el título de magno a san Juan Pablo II, añade:

Lo cierto es que en Juan Pablo II, el poder y la bondad de Dios se han hecho evidentes para todos nosotros. En un momento en que la Iglesia está sufriendo de nuevo la presión del mal, es un signo de esperanza y aliento. (Benedicto XVI, 2020)

En otro contexto, Delgadillo (2017), en un artículo sobre el pensamiento de Emmanuel Levinas (2005), deja claro que aportaba enseñanzas sobre el alcance del verdadero ethos al insistir en que no desentenderse de las cargas ajenas es ser responsable, puesto que quien así procede sale de sí mismo para reconocerse en el otro y ponerse al servicio de los demás, cuenta con ojos para ver y oídos para escuchar, no se pone en el centro, sino que sirve a los demás. Hace referencia a que Dios siendo infinito, se presenta como "huella" en el sentido de ir hacia los otros, en un anonadamiento para estar con los demás, con el prójimo. Ese encontrarse 
de Dios fuera de sí mismo como una huella en el camino hacia los demás, no significa en esa ausencia ni olvido ni muerte como lo proclama Nietzsche, sino que se hace realmente vivo y presente clamando desde las necesidades y dolores de la humanidad. El rostro del prójimo es el ubi de su mandato y un fuerte apelo a la responsabilidad. De ese modo, en el infinito se hace prójimo y llama al finito a la infinitud cuando obra de ese modo (Levinas, 1995).

En la primera parte de El humanismo del otro hombre, Levinas (2006), expresando con claridad su pensamiento, concluye que:

El Dios que ha pasado no es modelo del cual el rostro sería la imagen. Ser a la imagen de Dios no significa ser el icono de Dios, sino encontrarse en su huella. El Dios revelado de nuestra espiritualidad judeocristiana conserva todo lo infinito de su ausencia que está en el "orden" personal mismo. [...] Ir hacia él no es seguir esta huella que no es un signo. Es ir hacia los Otros que se encuentran en la huella [...]. (p. 82)

Encontrar a Dios en el prójimo es lo que da sentido a lo religioso, que se concreta cuando se da el paso de lo sagrado a lo santo (Delgadillo, 2017).

\section{El ethos cristiano: hacia unas humanidades performativas}

A partir de los diferentes ejes de análisis abordados en este trabajo se puede establecer que, desde la filosofía griega clásica, el ethos puede ser entendido como ese "modo o forma de vida, en el sentido hondo de la palabra" (Zubiri, 1950, p. 259), opuesto al pathos, referido a la naturaleza humana imperfecta, en su nivel de afectación antes del ejercicio de la libertad propia del hombre. En tal sentido, la labor de la ética es darle a ese pathos, como realidad informe derivada de la imperfección de nuestra naturaleza, una configuración acorde con su vocación a la perfección. El punto de partida para ello, desde la fe católica y el pensamiento cristiano, es, como lo indica Karol Wojtyla, la realidad de Dios: "solo Dios, el bien supremo, constituye la base inalterable y la condición irreemplazable de la moralidad" (Veritatis Splendor, 99).

Así, frente al ethos sin la gracia, frente a las éticas sin Dios, se constituye un ethos cristiano en cuyo centro se encuentra la vida moral moldeada por la fe: ello, como 
lo muestra Pérez-López (2004), "constituye un ethos, una forma de ser y estar en la vida, informada siempre por una interpretación que tiene en cuenta lo ya recibido por la vida ética y la exigencia crítica de la fe misma" (p. 31).

Más allá de las expresiones de las éticas sin Dios, del subjetivismo y del utilitarismo mencionados, la originalidad de la ética de la fe cristiana y la creatividad de la propuesta católica acerca del ethos cristiano residen en que este, "como aportación a la historia de la humanidad, no expresa el ser del hombre centrado en sí mismo sino abierto a la acción del Espíritu Santo" (Pérez-López, 2004, p. 36). Ello aparece expresado en el Catecismo de la Iglesia católica como una realidad de tipo cristológica:

Cristo es el centro y el modelo de toda la vida moral cristiana [para la] imitación y el seguimiento de Jesús como oferta realizable para todos, a través de la vivencia de las virtudes con la ayuda de la gracia, los sacramentos, la oración. (Pérez-López, 2004, p. 38)

El ethos cristiano es el eje de una educación centrada en la persona, que promueva y realice el esfuerzo de extraer, de la realidad informe de nuestra condición imperfecta, una conducta humana, esfuerzo y desafío que han de cumplirse desde la libertad y con apertura a la gracia.

Tomando en consideración que la vivencia interior del ethos cristiano exige una motivación en el amor como centro de la conducta moral para la vida en el servicio al mundo (Pérez-López, 2004), cabe preguntarse si unas humanidades que solo apunten a un ethos sin la gracia o que, en otros términos, solo informan conocimientos y carecen de espiritualidad, podrán tener un carácter performativo, es decir, transformador.

Si solamente se mueven con argumentos de razón y sin compromiso con el corazón, aspecto este último que únicamente es posible lograr por la vía de la gracia, las humanidades pueden no solo mostrarse superfluas sino aun volverse contraproducentes, en la medida en que pueden terminar en un bello e impracticable discurso que contribuiría a alimentar la posición de aquellos que las miran con prevención, considerándolas algo impracticable y propio de soñadores. 
También debe tenerse en cuenta que separar el cultivo de las humanidades de la dimensión y la presencia de la gracia es consentir en la tentación que no buscar otra cosa sino separarnos de Dios. En definitiva, según lo que se ha venido tratando, es optar por un ethos sin Dios. Abandonar las humanidades al mero discurso es tornarlas vacías e ineficaces.

Los indicadores de los bajos resultados en competencias ciudadanas, en índices de corrupción (Transparencia Colombia, 2018), en inequidad (Portafolio, 2019), individualismo y consumismo cosificante, además de violencia de género e intrafamiliar (Ministerio de Salud y Protección Social, 2018; Vicepresidencia de la República, 2020) y contra la infancia (Instituto Colombiano de Bienestar Familiar, 2018), entre incontables males, dejan en evidencia la urgencia de que, desde la inteligencia y la libertad, permitamos la acción de la gracia y el regreso de Dios a la historia (Ministerio de Salud y Protección Social, 2018).

El ya citado Instrumentum Laboris para el sínodo sobre los jóvenes, la fe y el discernimiento vocacional (Sínodo de los Obispos, 2018a) se refería en estos términos a la incertidumbre, miedo y esperanza de los jóvenes:

Los padres sinodales evidenciaron "la contingencia y fragmentación existencial" que les ocasiona "falta de seguridad" e "incertidumbre", la dispersión les "genera confusión", "la presencia de odio y violencia, miedo" y se pregunta cómo hacerlos "profetas de la esperanza" cuando en el mundo "reinan la corrupción y la injusticia”, se ven en la situación de Jeremías "iAh, Señor! iMira que no sé hablar porque soy demasiado joven!" (Jeremías l: 6). Jeremías "encuentra la paz” con la respuesta divina: "No temas delante de ellos, porque yo estoy contigo para librarte" (Jeremías l:8) (p. 78).

El documento oficial de la XV Asamblea Ordinaria del Sínodo de los Obispos denominado Los jóvenes, la fe y el discernimiento vocacional (Sínodo de los Obispos, 2018b), hace referencia a la libertad herida y redimida:

La libertad humana está marcada por las heridas del pecado personal y de la concupiscencia. Pero cuando, gracias al perdón y a la misericordia, la persona toma conciencia de 
los obstáculos que la apresan, crece en madurez y puede empeñarse con más lucidez en las decisiones definitivas de la vida. (Sínodo de los Obispos, 2018b, numeral 76)

Enseguida advierte cómo, desde "una perspectiva educativa", se debe acompañar a los jóvenes para que no se desanimen ante los errores y fracasos, "porque forman parte integrante del camino hacia una libertad más madura, consciente de la propia grandeza y debilidad" (Sínodo de los Obispos, 2018b, numeral 76). Recuerda, además, que el mal no tiene la última palabra y el gran límite que lo gobierna:

Porque tanto amó Dios al mundo, que entregó a su Hijo unigénito (Jonás 3: 16). Él nos amó hasta el final y rescató así nuestra libertad. Muriendo por nosotros en la cruz derramó su Espíritu, y “donde está el Espíritu del Señor hay libertad" (2.․ de Corintios 3: 17): una libertad nueva, pascual, que se cumple en la entrega cotidiana de sí. (Sínodo de los Obispos, 2018b, numeral 76)

Los centros educativos tienen que velar por la educación de los jóvenes, bajo esa grata perspectiva, para que comprendan como es, mediante la gracia, que brinda el amor de Dios y la libertad que prodiga el Espíritu Santo, que se puede superar y desterrar el mal. No hacerlo sería abandonarlos, en la inmadurez, a un precario ejercicio de la libertad, el error y el fracaso.

Se les debe animar a unirse con un Dios, que los llama sus amigos, en un gran "proyecto de amor", que lo "escuchen" para que conozcan su "vocación", "que es un don de gracia y alianza", el secreto más bello y valioso de la libertad, el camino hacia la felicidad (Sínodo de los Obispos, 2018b, numeral 78).

No escapa al documento la centralidad de la Eucaristía como "generadora de vida comunitaria", "formadora de la misión" que "vive por la gracia y no por las obras de sus propias manos" (Sínodo de los Obispos, 2018b, numeral 134).

Acerca de esta temática y de la necesidad de abordarla en profundidad, encontramos en las orientaciones del documento sinodal sobre la juventud una gran síntesis del pensamiento de la Iglesia sobre el ethos y la gracia. Ello constituye una hermenéutica de estos dos grandes ejes en la formación espiritual de la humanidad y particularmente de la juventud. 


\section{Conclusiones}

Este capítulo, derivado de los resultados de la investigación Relación entre capital psicológico y capital ético aplicado a los valores corporativos de la Universidad Católica de Colombia (Ospina Hernández y Delgado Abella, 2019), apunta a la conclusión de que la apertura a la gracia es esencial para que la educación y la humanidad logren sus buenos propósitos.

Dicen que las águilas pueden mirar fijamente al sol sin retirarle la vista. A san Agustín lo llamaban el águila de Hipona porque su visión no pestañeaba delante de los grandes misterios de la fe, particularmente, el del carácter trinitario de la gracia.

Fra Angélico representó en el arte lo que santo Tomás de Aquino explicitó desde la Teología, la hermenéutica de la pintura sobre la anunciación aproxima al espectador a ser un testigo de esa gran escena con precisión, lujo y delicadeza de detalles. Bien decía santo Tomás, para que exista la belleza son necesarias tres cualidades: en primer lugar, la integridad, pues las cosas inacabadas, como tales, son deformes. A seguir, la proporción armónica entre las partes. Finalmente, la claridad, pues consideramos bellas las cosas de colores claros y brillantes (Alarcón, 2019).

En la obra de Fra Angélico se vive el octavo día de la creación, obra de la gracia de Dios en María. Se aprecia el significado de la salutación del arcángel cuando la llama la plena de gracia, exenta de temor y colmada de felicidad.

Se ha podido ver, por otra parte, que en los fundamentos de la reflexión sobre la educación ética convergen la hermenéutica sobre el ethos y la gracia de Plinio Correa de Oliveira, san Pablo, san Agustín, el Concilio de Trento, el acuerdo con la Federación Luterana, el Catecismo de la Iglesia, santa Edith Stein, Levinas, Benedicto XVI, san Juan Pablo II, los padres sinodales que trabajaron en el Sínodo de la Juventud.

Lo primero que debe reivindicarse es el papel de la gracia en el buen obrar humano, que va más allá de la obra y se deriva hacia la buena persona que es aquella que 
recurre y escucha el auxilio de la gracia; que no está centrada en su egoísmo sino en hacer el bien a sus congéneres.

Lo segundo que un ethos que ignora la gracia ignora a Dios y no pasa de ser un agravante y una burla al bien y a los buenos, que pueden desesperar de unos enunciados sin carne y sin corazón, sin Dios, sin perdón y sin amor.

En tercer lugar, que cuando el ethos y la gracia se juntan, la mente se abre a Dios, a la persona, a la compasión y a la felicidad: se entra en el octavo día de la creación. En tal sentido, los fundamentos de un ethos cristiano muestran la centralidad de la figura de Cristo como modelo de todo comportamiento moral. Ello a su vez se constituye en fundamento y tarea de la educación y de unas humanidades capaces de obrar la transformación del pathos de la imperfección al ethos de una forma de ser y de estar en la vida como imitación de Cristo.

En ese luminoso escenario debe ordenarse el acto educativo a la sabiduría de las bienaventuranzas, que orientan un compromiso socialmente radical en dirección a una fe robusta, un generoso desprendimiento, una mansedumbre a toda prueba, un alma pacífica y misericordiosa, aunados a una sed y un hambre de justicia, que contribuyan eficazmente al trinomio persona, compasión y felicidad.

\section{Referencias}

Alarcón, E. (ed.) (2019). Corpus Thomisticum. Subsidia studii ab Enrique Alarcón collecta et edita Pompaelone ad Universitatis Studiorum Navarrensis aedes ab A. D. M. M. https://www.corpusthomisticum.org/

Bello, H. (2013). Claves para la comprensión del concepto de libertad en Edith Stein a partir de su obra NLG. En II Seminario Internacional de Bioética-Mujer y Corporeidad (pp. 63-79). Santiago de Chile: Universidad Fines Terrae.

Benedicto XVI. (2007). Jesús de Nazareth. Bogotá: Planeta.

Benedicto XVI. (2020, 18 de mayo). Carta al Episcopado Polaco: las palabras del Papa emérito sobre la misericordia en San Juan Pablo II. Vatican News. https://www.vaticannews.va/es/papa/news/202005/palabras-papa-emerito-sobre-misericordia-san-juan-pablo-ii.html

Comisión Teológica Internacional. (1988). La moral cristiana y sus normas. Librería Editrice Vaticana. Correa de Oliveira, P. (1978). Revolución y contra-revolución. Madrid: Fernando III El Santo. 


\section{8 - M A E S T ROS}

Ethos y gracia en la educación de los jóvenes

Correa de Oliveira, P. (2005). El beato Fra Angélico, el Santo Tomás de la pintura. Revista Dr. Plinio, 83, 26-30. https://es.arautos.org/view/show/85457-el-beato-fra-angelico-el-santo-tomas-de-la-pintura

Curia Pontifical Romana. (1999). Declaración Conjunta sobre la Justificación. http://www.vatican.va/ roman_curia/pontifical_councils/chrstuni/documents/rc_pc_chrstuni_doc_31101999_cath-luth-joint -declaration_sp.html

Datos Macro. (2018). Crece la percepción de corrupción entre los colombianos. https://datosmacro.expansion.com/estado/indice-percepcion-corrupcion/colombia

Delgadillo, J. (2017). Cuatro claves antropológicas en humanismo del otro hombre de Emmanuel Levinas. Veritas, 4-16.

Dubreton, L. (1961). La vida cotidiana en Florencia en tiempos de los Medicis. Buenos Aires: Hachette.

Garcés, L. y Giraldo. C. (2014). La justicia aristotélica. Indivisa, 14, 44-52.

Iglesia Católica. (2005). Catecismo de la Iglesia católica-compendio. http://www.vatican.va/archive/ compendium_ccc/documents/archive_2005_compendium-ccc_sp.html

Instituto Colombiano de Bienestar Familiar. (2018, 19 de octubre). ICBF atiende 68 casos diarios de violencia contra la niñez en todo el país. htps://www.icbf.gov.co/noticias/ icbf-atiende-68-casos-diarios-de-violencia-contra-la-ninez-en-todo-el-pais

Levinas, E. (1995). Alterité et transcendence (p. 88). París: Fata Morgana.

Levinas, E. (2005). Difícil libertad. Ensayos sobre el judaísmo. Buenos Aires: Lilmod.

Levinas, E. (2006). Humanismo del otro hombre. Ciudad de México: Siglo XXI.

López de Ayala, I. (1847). El sacrosanto y ecuménico Concilio de Trento. Barcelona: Imprenta Don Ramón Martín Indar.

MacIntyre, A. (1994). La justicia en Aristóteles. Barcelona: Eiunsa.

Medina Delgadillo, J. (2019). La filiación como trascendental personal. Correlatos, 109-126.

Meis, A. (2014). Edith Stein, naturaleza, libertad y gracia. El espíritu finito y su dramaticidad en el mundo. La Revista Católica, 225-234.

Ministerio de Salud. (2018). Sala situacional mujeres víctimas de violencia de género. https://www. minsalud.gov.co/sites/rid/Lists/BibliotecaDigital/RIDE/DE/PS/sala-situacion-violencia-genero.pdf

Ospina Hernández, C. A. y Delgado Abella, L. E. (2019, septiembre). Repositorio Biblioteca Universidad Católica de Colombia. https://repository.ucatolica.edu.co/bitstream/10983/23756/1/Relacion-entrecapital-psicologico-y-capital-etico-aplicado-a-UCat\%C3\%B3lica-de-C.pdf

Pérez-López, S. (2004). El ethos cristiano. Theologica, 39 (1), 29-53.

Portafolio. (2019, 12 de julio). Colombia es cada vez más desigual, asegura el DANE. https://www.portafolio.co/economia/colombia-es-cada-vez-mas-desigual-asegura-el-dane-531503 
San Agustín. (1913). De natura et gratia (Corpus Scriptorum Ecclesiasticorum Latinorum, 60). Lipsiae: Carolus Urba y Joseph Zycha. https://journals.openedition.org/criticon/2555

San Agustín. (1981). A. Trape, Sant'Agostino. Natura e Grazia 1. (Opera Omnia di Sant'Agostino, XVII, pp. 241-363). Roma: Instituto Agustinianum. http://www.misticayrazon.cl/documentos/libertad como_gracia_en_san_agustin.pdf

Secretaría General del Sínodo de los Obispos. (2018, 3-28 de octubre). Los jóvenes, la fe y el discernimiento. http://www.synod.va/content/synod2018/es/documentos/documento-final-del-sinodo-delos-obispos-sobre-los-jovenes.html

Secretaría General del Sínodo para los Obispos. (2018). Instrumentum laboris para el Sínodo sobre los jóvenes. http://www.synod.va/content/synod2018/es/documentos/instrumentum-laboris-para-elsinodo-sobre-los-jovenes-2018.html

Stein, E. (2002). Naturaleza, libertad y gracia. Vitoria: Orden Carmelita.

Vasari, G. (1550). Vidas de Giorgio Vasari. Torrentina. http://www.historia-del-arte-erotico.com/vasari/ home.htm

Vicepresidencia de la República de Colombia. (2020, 6 de abril). La violencia intrafamiliar es otra pandemia que el Estado en pleno está dispuesto a derrotar. https://mlr.vicepresidencia.gov.co/Paginas/ prensa/2020/La-violencia-intrafamiliar-es-otra-pandemia-que-el-Estado-en-pleno-esta-dispuestoa-derrotar-Vicepresidente.aspx \#:-:text=Del\%20total\%20de\%20llamadas\%20durante,procesos\%20 pertinentes $\% 20$ en $\% 20$ cada $\% 20$ caso

Wojtyla, K. (2008) Amory responsabilidad. Madrid: Palabra. 



\section{2}

\section{Persona y sentido: la tarea esperanzada más allá de la felicidad. Una propuesta desde la Antropología Trascendental de Leonardo Polo}

María Victoria Cadavid-Claussen*

\section{Resumen}

Aunque la felicidad pareciera ser el fin del hombre, se plantea aquí que más allá de la satisfacción de las tendencias humanas naturales, o de la obtención intelectiva de plurales verdades acerca de la realidad intramundana y aun de la adherencia voluntaria a bienes inmateriales, la persona busca y da su sentido personal. El aporte de nuevo conocimiento filosófico de este trabajo contribuye a esclarecer desde la antropología en qué consiste ser sentido personal capaz de dotar de sentido a la propia existencia, más allá de la consecución o no de la felicidad, mediante la tarea esperanzada durante su estar en la historia. Con un método inductivo se ahonda en la persona y su realización biográfica, a partir de algunas claves de la Antropología Trascendental de Leonardo Polo, porque su propuesta alcanza el núcleo constitutivo del ser personal como acto de nivel trascendental, a diferencia de otras propuestas antropológicas tradicionales, modernas y contemporáneas,

\footnotetext{
* Doctora en Filosofía de la Universidad de Navarra, Pamplona, España. Máster en Educación y Especialista en Desarrollo Familiar y Personal de la Universidad de la Sabana, Colombia. Docente de planta e investigadora del Departamento de Humanidades de la Universidad Católica de Colombia. Miembro del grupo de investigación Philosophie Personae del mismo departamento. mvcadavid@ucatolica.edu.co https://orcid.org/0000-0002-0882-2725
} 
más centradas en el ámbito manifestativo humano, el de la razón y la voluntad. Desde esa antropología, en este trabajo se avanza en el esclarecimiento de la pregunta por la persona y su sentido que, más allá que buscar su propia satisfacción felicitaria, es capaz de ir a más apertura íntima para dotar de sentido la tarea de existir en el mundo, de personalizarlo, e incluso, de dotar de sentido personal el sufrimiento, cuestión que comparece al margen de la felicidad. El presente estudio inductivo concluye que la persona humana es un ser de sentido capaz de dotar de su luz la realidad temporal mediante su tarea esperanzada. Con este aporte existencial ella misma se humaniza humanizando. Así, más allá del intento de encontrar la felicidad como fin de su existencia, el ser humano descubre y dota de sentido su propia realidad temporal orientado a su existencia metahistórica, en la búsqueda del sentido personal que es y que está llamado a ser.

Palabras clave: persona, sentido personal, Leonardo Polo, Antropología Trascendental.

\section{Introducción}

Este trabajo se realiza con base en la propuesta filosófica de la Antropología Trascendental de Leonardo Polo (1923-2013). Según L. Polo, en su núcleo constitutivo, el ser personal es puro intelecto en acto, amante, libre y abierto a coser con las otras personas, las divinas, las espirituales y las humanas. Estos los propone como trascendentales antropológicos. A partir de estos rasgos radicales propios de ser personal se vislumbra de momento que a la persona humana no le basta conseguir para sí misma el bien, sino coexistir libre con cada persona para conocerla y amarla, esto es, para aceptarla y donarle de sí.

Este pensador contemporáneo español presenta un método que permite conocer los distintos actos de ser, el acto de ser personal humano y el ser metafísico, así como sus respectivas manifestaciones. A este método lo denominó abandono del límite mental, y consiste en avanzar por la vía de las operaciones cognoscitivas, no del objeto pensado, hacia modos de conocer superiores que alcanzan, advierten o explican temas o realidades también superiores a las inteligidas por la razón, es de- 
cir, distintas de las conocidas por el mero conocimiento objetual propio de la abstracción o primera operación de la inteligencia. Con una de las dimensiones de este método, el ejercicio del hábito de sabiduría, se alcanza el núcleo del ser personal, del que depende la esencia o manifestación biográfica del hombre. En su esencia el hombre se manifiesta como persona, configura la sociedad y habita el mundo.

En el ser personal y sus manifestaciones se ubica esta investigación. Se propone aportar en el ámbito filosófico a una antropología de la persona y su sentido en estrecha vinculación con su existencia en el tiempo. En este estudio se avanza desde algunas claves presentadas por la propuesta de Polo, de los trascendentales antropológicos, a un nuevo conocimiento en el que se propone este núcleo radical como núcleo de sentido íntimo desde el que la persona dota el mundo mediante su tarea existencial. Con esto, se intenta dilucidar que más allá que buscar la felicidad para sí, la persona busca su sentido, a la vez que atraviesa la sociedad de su luz intelectual libre y amante mediante dones amorosos que la manifiestan. Así, la persona humana aporta a la orientación humana de la marcha de la historia y con ello también contribuye a su propio crecimiento.

Por lo pronto, interesa conocer cómo la persona dota de sentido su existencia y cuál es la dinámica de la tarea existencial mediante la que coexiste con otros y manifiesta su luz intelectual, libre y amorosa, con la que aporta a la sociedad.

Se presentará un breve contexto del marco antropológico en el que se investiga, para exponer el núcleo constitutivo del ser personal, para luego ahondar en la tarea existencial del hombre que, como ser de sentido, tiene por delante manifestarlo al estar situado temporalmente en la historia.

\section{Metodología}

La investigación es de tipo descriptivo (Hernández, Fernández y Baptista, 2006), sistémico o reunitivo (opuesto al analítico, usual en ciencias experimentales) porque en el hombre todas sus manifestaciones están interrelacionadas. Se responde en todo caso a un enfoque cualitativo apoyado en referencias bibliográficas. El estudio, según Hernández, sigue el método inductivo (Hernández, Fernández y Baptista, 2006). 
Persona y sentido: la tarea esperanzada más allá de la felicidad

Apoyado en la técnica de recopilación y análisis documental (Madé, 2006) se procede a establecer en la propuesta antropológica del autor estudiado los aportes más relevantes respecto de la persona y su sentido en la sociedad, para propiciar, más allá de la consecución de la propia felicidad, la apertura de nuevos ámbitos que el mismo Polo designa como agentes de cambio social. Según esto, se afirma aquí que la tarea del hombre iluminada por su ser personal atraviesa todo ámbito humano haciendo posible el mutuo crecimiento. Cabe indicar que el estilo propio del autor presenta en sí mismo un desafío investigativo para recabar en los múltiples aportes introducidos en varias de sus obras, pero, en consonancia con temas distintos. Eso se debe principalmente al alcance, fecundidad y profundidad de su pensamiento, así como al rigor con el que afronta su reflexión filosófica. De modo que este método resulta útil, aunque a la vez dispendioso para desvelar la consistencia de sus argumentos con relación a cuestiones específicas. Así mismo, la metodología empleada facilita también descubrir el hilo conductor de la investigación, pues al seguir el itinerario de los temas tratados por este autor se muestran otros que evidencian el juego riguroso de síntesis filosófica que él realiza. Esto permite aclarar, pero también exige acotar el complejo conocimiento de la realidad plural que el autor estudiado desvela. Esto se consigue, para el objeto de este trabajo, al seguir un itinerario centrado en la manifestación de la persona en su esencia, en el tema específico que se pretende mostrar, la tarea esperanzada.

Por otra parte, como el propósito de este estudio consiste en dilucidar la tarea esperanzada como manifestación humana del sentido personal, más allá que el afán de conseguir la propia felicidad se avanzará sobre las claves antropológicas del autor para mostrar que en ella se configura la dotación de sentido personal a la sociedad como aportes que manifiestan a la persona. No se pretende, por tanto, realizar contrastes con otros pensamientos filosóficos.

\section{Breve contexto de la propuesta antropológica trascendental}

Con el fin de resguardar el rigor filosófico en el que se apoya este estudio sobre la persona y su sentido más allá de la búsqueda de su felicidad, cabe destacar que 
la particularidad de la propuesta antropológica de Polo no trata sobre el sentido personal. Para lo referente a aclarar el núcleo personal, al que por ser intelecto nos referimos como sentido personal, se presenta este breve itinerario filosófico en el que Polo lo desvela. El avance sobre su propuesta parte de que se alcanza a la persona como acto de ser de nivel trascendental. Este "alcance" de la intimidad personal significa para Polo adentrarse en el núcleo del puro acto de ser de la persona. Con esto se pretende continuar la filosofía tradicional y resolver las cuestiones no logradas por la filosofía moderna en su intento de dar cuenta del "sujeto" o del "yo", desde la razón o la voluntad, pero no desde la persona, en una clara simetrización (Polo, 2016) con los trascendentales metafísicos, propios de los principios del ser del universo, pero sin avanzar a desvelar los antropológicos:

La filosofía de los últimos siglos se centra en el estudio del hombre entendido como sujeto. Por más que la antropología clásica sea correcta y su metafísica válida, la ampliación temática intentada en la filosofía moderna no puede ser asimilada por un pensador que admita la filosofía tradicional o que parta de ella, si no se atreve a abrir el ámbito de la antropología trascendental; en otro caso, parece existir un divorcio entre la filosofía tradicional y la moderna. (Polo, 2016, p. 39)

Es pertinente notar esta aporía, sin detenernos en ella, para entender por qué en la filosofía moderna no se alcanza el ser personal ni su sentido, por el contrario, se desdibuja.

De aquí que, el itinerario que Polo sigue amplía desde los trascendentales tradicionales a los trascendentales propios de la persona. Ese tiene su inicio en la criba que el filósofo realiza de los trascendentales descubiertos por la filosofía medieval para, al ampliarlos, alcanzar los trascendentales antropológicos. A aquellos los denomina metafísicos porque corresponden al ser del universo. Sin embargo, de ellos establece que no todos son trascendentales y que faltan otros que sí lo son; por esto, después de la criba, procede a ordenarlos y a establecer su elenco: el ser, como trascendental absoluto, y la verdad y el bien, como trascendentales relativos. En este punto, descubre que sin el acto de ser personal estos trascendentales no son posibles porque se refieren a él. De modo que resulta conveniente desvelar el ser personal y descubrir sus trascendentales antropológicos constitutivos. 
Persona y sentido: la tarea esperanzada más allá de la felicidad

Con esto también se aclaraba la distinción entre el ser antropológico, el personal, y el metafísico, el del universo. En esto consiste su "ampliación trascendental" (Polo, 2015).

Con el nuevo elenco de trascendentales este filósofo continuó los hallazgos de la filosofía aristotélico-tomista, para alcanzar el propio núcleo del ser personal más allá de sus manifestaciones esenciales, cuestión que no se había alcanzado hasta ahora: "si la metafísica permite descubrir trascendentales, al tratar del espíritu se conseguirá alcanzar otros" (Polo, 2016, p. 4l). De modo que desde la filosofía aristotélica avanza sobre el "intelecto agente como intelecto trascendental constitutivo del ser personal" (p. 138); desde la tomista, esclarece para la antropología la distinción entre la dimensión trascendental del acto de ser personal, y la esencia del hombre como ámbito manifestativo en el que la persona dispone de sus potencias espirituales, inteligencia y voluntad, para acrecentarlas, conocer, querer y aportar al mundo.

En suma, a este punto se afirma que lo propio de la persona es ser luz en su núcleo más íntimo que se manifiesta a su esencia. En su manifestación el ser humano configura la sociedad y en ella abre nuevos ámbitos como la familia, la universidad y la empresa, a los que Polo describe como las principales instituciones capaces de impulsar el auténtico cambio social más allá de las instituciones políticas. Como aquellos manifiestan al ser personal que los configura, entre ellos se conforma una simbiosis libre propicia para la humanización del mundo atravesado por la luz personal que media la tarea. Así lo expone Polo (2015): "En estas tres instituciones se concentra la energía social, pues la iniciativa humana se pone en marcha en la medida en que tales instituciones dan de sí” (p. 276).

Por lo pronto este trabajo se centra en la tarea de existir como manifestación personal mediante la que se dota a la sociedad de sentido personal. Pero, se plantea ese trasfondo de ámbitos humanos porque en ellos la persona realiza su tarea, dona sus dones amorosos y los acepta de ellos, así se sitúa temporalmente en el mundo. 
Con todo, cabe recalcar que los ámbitos sociales humanos son manifestación "esencial" de la persona constituida en su núcleo más íntimo por los trascendentales de nivel antropológico: la coexistencia libre, el conocer y amar personales que son inagotables. Por consiguiente, si la esencia es la dimensión a la que la persona deriva su luz trascendental para manifestarse y dotar de sentido su modo de estar en el mundo, también los ámbitos sociales que en ella abre, la familia, la educación, el trabajo, son susceptibles de crecimiento o de más humanización y, por tanto, son también medios para que el hombre, situado en el tiempo, alcance mayor plenitud de sentido en su vida. De modo que la capacidad de humanizar se apoya primero en el núcleo del ser personal capaz de derivar su sentido y, segundo, en esos ámbitos o itinerarios humanizadores como medios para el logro del auténtico cambio social. Y al ser capaces de coexistir entre sí estos ámbitos para humanizarse y humanizar, configuran una simbiosis positiva de intercambio mutuo de dones personales, que abiertos el uno al otro, aportan a la auténtica innovación social.

Esta dinámica humanizadora atraviesa de novedad personal las estructuras sociales, algunas de ellas vaciadas de sentido por el imperio de la tecnocracia sobre el sentido mismo de la acción humana, Según Polo (2015):

el imperio de la razón mecanizada acaba reduciendo al ser humano a elemento de estructuras impersonales. Para recuperar el ámbito de sentido de la vida hay que inyectar en esas estructuras impersonales las relaciones interpersonales, restableciendo la colaboración, organizando la cooperación humana. (p. 65)

\section{La persona humana y su sentido}

Para continuar la propuesta de la persona y su sentido se precisa conocer acerca de la radicalidad constitutiva del núcleo personal humano, tal como Polo lo descubre. Cabe por lo pronto subrayar que al "acto de ser" humano, Polo (2015) lo denomina persona. Este núcleo es por tanto trascendental. Pero para manifestarse en el mundo la persona dispone de su "esencia", a la que acrecienta por sus potencias superiores, y de su "naturaleza" corpórea. Según los trascendentales antropológicos que constituyen el ser personal se puede afirmar que el ser del hombre 
Persona y sentido: la tarea esperanzada más allá de la felicidad

es intelecto superior libre, abierto y amante: "la persona es intimidad abierta: luz intelectual, libertad trascendental, amar donal" (Polo, 2016, p. 137). Es pertinente resaltar aquí que el ser personal es luz trascendental, por tanto, capaz de atravesar cognoscente de toda realidad; por otra parte, más que el mero existir del ser cósmico, si el ser personal es apertura en acto, "el acto de ser personal, al que llamo coexistencia, intimidad" (Polo, 2015, p. 231), por lo que en realidad se trata de un coser capaz de ser con otros por lo que en su ámbito manifestativo constituye sociedad y aporta.

Como la persona es en su radicalidad un intelecto trascendental, es un conocer en acto que busca otra verdad personal superior capaz de dar respuesta a su sentido. De modo que, la persona en su búsqueda, abarca las preguntas trascendentales que abordan los temas radicales acerca de quién es, cuál es su origen y su destino, y el para qué de su existencia. Según estas cuestiones se puede describir el ser humano como un buscador de sentido. Así, al buscar, el ser humano se abre simultáneamente a la aceptación de sí mismo como "verdad personal" (Polo, 2016, p. 86) superior a las conocidas intramundanas, así como núcleo de intelecto radical constitutivo de su ser que busca su origen: "La demostración de la existencia de Dios en antropología se expresa de esta manera: si Dios no conociera al hombre, no cabría hablar de intelecto humano como coactus" (Polo, 2016, p. 148). Desde esta verdad personal que es búsqueda la persona se abre también a existir en plenitud de sentido. Sin embargo, esto no se logra solo, porque se descubre como coexistencia. Este es uno de los rasgos constitutivos del ser personal. Según Polo (2015), coexistencia designa la apertura íntima trascendental de la persona, por la que el ser personal es radicalmente capaz de ser-con-otras personas, dentro y fuera del tiempo, incluido Dios. También el ser personal se abre a existir con el cosmos, pero de un modo distinto, porque el cosmos no es persona.

Con todo, la coexistencia o coser no es el único trascendental antropológico que Polo (2015) desvela como constitutivo del ser personal, sino que como el ser es un además de apertura radical para "ser-con-otros", este coser se convierte a su vez con otros rasgos radicales que también son propios del ser personal. Estos son 
la libertad personal, el intelecto o conocer personal y el amar personal. Que se convierten significa que no caben el uno sin el otro.

La libertad personal indica la pura actividad del espíritu con la que la persona es siempre abierta al futuro, sin posibilidad de quedarse estática o cerrada en la caducidad del tiempo, sino en avance esperanzado orientado a su destinatario final. Esto denota que es el ser capaz de crecer y de saltarse el tiempo, de ser metahistórico, a su vez, capaz de atravesar de actividad libre su esencia y hasta su naturaleza corpórea:

por ser el trascendental que simplemente se alcanza, y la actividad que posee el futuro sin desfuturizarlo, la libertad trascendental se puede describir como el sentido más estricto de la novedad. Según la libertad, cada persona humana es un novum. (Polo, 2015, p. 262)

Debido a este ser novedad se afirma que el sentido personal es la inagotable actividad de luz intelectual de carácter personal capaz de derivarse al ámbito esencial o manifestativo del hombre para dotarlo de su luz amorosa.

Con todo, esa actividad personal libre no es arbitraria, sino orientada, puesto que el coser personal también es puro intelecto trascendental; por tanto, un puro conocer en acto, superior a la razón, que es potencia, no acto de ser. Como acto de ser personal tal conocer es buscador de su origen, pues se trata de un ser originario que también es personal. Así mismo, también está abierto a las otras personas. A su vez, el intelecto personal es la apertura íntima de luz o transparencia, que la acepta y la da: "la persona, a la que también llamo el núcleo del saber, es luz en la luz, es decir, la transparencia. Sin la transparencia intelectual no es posible hablar de intimidad" (Polo, 2015, p. 254).

Cabe anotar que este alcance acerca del acto de ser personal como intelecto trascendental proviene del hallazgo aristotélico del intelecto agente, pero vislumbrado como trascendental antropológico, es decir, visto el puro intelecto como ser personal íntimo que busca al ser que es su origen, que es capaz de iluminar toda realidad, que se abre a sí mismo para dar cuenta de sí, a las otras personas divinas y humanas, y al cosmos. He aquí el contraste con el hallazgo aristotélico: 
Persona y sentido: la tarea esperanzada más allá de la felicidad

"el intellectus ut co-actus es la elevación al nivel trascendental de lo que en la tradición se llama intelecto agente" (p. 254).

Esta múltiple apertura del intelecto personal denota no solo la novedad e inagotabilidad en la apertura luminosa, sino la orientación del ser personal que es luz o sentido a otra persona sin el límite del tiempo, pero también dentro de él. Esto aclara el carácter unitivo del sentido personal como luz capaz de conocer desde el tiempo a su origen fuera del tiempo, a la vez que, iluminar la acción humana dentro de él. El sentido personal, por tanto, va más allá de la mera historia, aunque esté situado temporalmente en la historia. A su vez, su estar en ella no es impersonal, sino por el contrario, la dotación de su propia luz a las realidades intramundanas.

De aquí que afirmemos la actividad iluminante del sentido personal que atraviesa todas las capas en las que manifiesta su ser. Esto es debido a que el intelecto personal es coexistencia, o pura apertura íntima, vierte su luz derivándola a todas las dimensiones que dependen de él en una "cascada" de aperturas cognoscentes por las que el ser humano se abre a toda la realidad dotándola de sentido, en cada dimensión con un método particular. Desde el propio núcleo, este sentido personal es la luz del intelecto radical, pero su plenitud la descubre al aceptar y ser aceptado por su Origen. Así mismo, el sentido personal "otorga" su luz al ámbito de sus manifestaciones humanas, o sea, a su "esencia". Tanto la búsqueda como el otorgar sentido, son actividad libre de luz en un juego de ascenso y descenso. Cabe, por tanto, subrayar que:

Solo desde la libertad personal adquiere su verdadero sentido la libertad de la esencia humana. Esta es la propuesta de Polo. Pero solo la antropología trascendental, distinta realmente de la metafísica y de la antropología como filosofía segunda, puede "alcanzar" el verdadero sentido de la libertad en todas sus dimensiones. (Polo, 2017, p. 16)

Así que desde el puro núcleo radical, el intelecto personal se abre a conocer toda realidad según el correspondiente modo de conocerla: por su "hábito de sabiduría", que alcanza a su propio ser personal, puesto que este método es el conocer lo propio de la realidad antropológica radical, "el hábito de sabiduría como 
alcanzarse sin culminación es equivalente al valor metódico del carácter de además, a la coexistencia, al intellectus ut co-actus" (Polo, 2016, p. 148). Por otro método, el "hábito de los primeros principios", se abre al ser del cosmos, pues con esta apertura cognoscente se conoce la realidad metafísica principal: "Con el hábito de los primeros principios se advierte el ser principal. Como los primeros principios son axiomas, al advertir que son extramentales se formula axiomáticamente la metafísica, lo que comporta una clara ventaja para la filosofía realista" (p. 134). A la vez, por el "hábito de la sindéresis" se abre a conocer su propia "esencia”, le deriva su luz para activarla y acrecentar sus potencias superiores, la inteligencia y la voluntad, de manera que se hagan capaces de abrirse a la realidad intramundana, como "es un hábito innato que ha de considerarse en orden a la voluntad y a la inteligencia. Por tanto, la sindéresis es el ápice de la esencia del hombre" (Polo, 2016, p. 134). Con esa apertura luminosa la persona abre su modo de realizar la existencia en el mundo. Se hace cargo de sus potencias dependientes de ella. Por consiguiente, la sindéresis es la luz cumbre del ámbito manifestativo, es propiamente el yo que ve y quiere, que las ilumina activándolas en dependencia del ser personal. Desde la sindéresis la persona se hace cargo de vincular todas sus manifestaciones. Con esto mediante sus potencias da cuenta de inteligir la pluralidad temática del mundo y adquiere verdades, así como, quiere los bienes de la realidad a los que tiende para tenerlos en forma de virtud. Así se manifiesta en la sociedad y conforma la cultura, a la vez que interactúa con la esencia del cosmos en la que habita por medio de su corporeidad.

El otro trascendental antropológico que sigue al intelecto personal es el amar personal: "el bien como trascendental en las criaturas espirituales se ha de entender como amar. El amar también está en el orden trascendental" (Polo, 2016, p. 85). Polo presenta el amar trascendental como una dualidad de aceptar y amar, siendo superior el aceptar. Esto denota la honda apertura amante del ser personal en referencia de coser íntimo y mutuo con otro ser personal. Del amar depende la estructura donal compuesta por el aceptar, el dar y el don. Los dos primeros son constitutivos del ser personal, pero el don se "inserta" en el ámbito manifestativo para poder ser dado en apertura esencial al mundo. 
Persona y sentido: la tarea esperanzada más allá de la felicidad

De las claves antropológicas expuestas proponemos que la persona como ser radical es un puro núcleo de sentido, esto es, de luz cognoscente que coes, en actividad libre y abierta, que se desborda en amar. Esto significa que el intelecto amante es luz intelectual desbordante de libertad, es pura apertura íntima, por esto, es luz que acepta al otro ser personal y luz que da.

De modo que el ser personal se abre amante como aceptar y dar personales. Según esto el acto de ser personal humano significa, por una parte, la radical apertura a la aceptación de las personas: de sí mismo, de Dios y de los demás, a su vez, implica la apertura como dar de su luz personal libre y amante concretada en los dones amorosos. Como no puede dar su propio ser sin perderlo, solo de Dios se da como don, la creatura humana es dar a través de sus dones de sentido por medio de su esencia. A ella le deriva su luz mediante la sindéresis, como ya se ha mencionado, pero antes la deriva a sus otras aperturas cognoscentes nativas superiores también ya mencionadas, a saber, la sabiduría y el hábito de los primeros principios.

Así que la luz del sentido personal se deriva a sus potencias para activarlas y acrecentarlas. En consecuencia, la persona abre el ámbito de sus manifestaciones en el mundo. Con ello, atraviesa de luz la existencia en el tiempo, en tanto que la personaliza al irrumpir en el ámbito de lo humano. Desde la inteligencia y la voluntad, suscita y constituye actos por los que se abre hacia afuera, con los demás seres humanos en la sociedad, sin perder la estrecha vinculación con la intimidad del propio núcleo de sentido personal amoroso. Por esto, afirmamos que el sentido personal que dota la vida humana es más hondo, o si se quiere, más alto, que la mera búsqueda de felicidad en el tiempo. Pues, vinculadas las acciones humanas al núcleo personal como dones de luz amorosa son por así decirlo "ascendidas" al ámbito de la intimidad personal o personalizada. De aquí que quepa su ofrecimiento al ser superior del que se deriva todo ser personal porque Él mismo es persona, como también, que cabe que el don amoroso esté por encima de la propia felicidad. De otro modo, ¿qué sentido tendría dar la vida por otros?

En consecuencia, como puro amar, la persona da sus dones amorosos como dotación de su sentido al mundo, es decir, aporta al ámbito esencial o manifestativo 
propio del encuentro con lo humano. Esto es así porque no puede dar su ser íntimo, pues dejaría de ser, por esto encauza el dar que es como dones a través de su esencia. De modo que es por medio de su esencia (inteligencia, voluntad y yo) por la que se abre a los otros que están en el tiempo para donar su sentido en derivación de su luz trascendental:

Para comprender las dimensiones sociales humanas, hay que realizar una advertencia previa: en el hombre existe una distinción real entre una dimensión que es más importante, la intimidad personal, y otra de segundo orden, manifestativo, que depende de la anterior. Pues bien, la dimensión social pertenece a este segundo plano. A ese miembro pertenecen las potencias humanas y lo social que manifestamos a través de ellas. En cambio, del primer orden es la vida íntima de cada quien, el corazón humano. (Sellés, s. f., p. 7)

En otras palabras, afirmamos que el dar íntimo del ser personal da sus dones amorosos dotados de sentido personal y acepta los de los otros. De modo que también cabe la posibilidad para el ser humano de descubrir ámbitos de intercambio de sentido personal a través de sus dones esenciales amorosos. Estos dones, por estar atravesados de luz personal, son dadores de sentido a los otros y a la cultura, como también son susceptibles de ofrecimiento al Ser Personal Originario. En suma, en la realización de su existencia biográfica, el ser personal manifiesta en todas sus dimensiones los rasgos de su luz trascendental íntima.

Por consiguiente, si la luz del sentido personal se vierte en la esencia del hombre, los dones que la persona da al manifestarse en sus acciones están transidos de su luz. Por esto también son susceptibles de ofrecimiento al Origen como dones de sentido de su vida en el tiempo. De aquí que, a la vez que la persona humana dota de sentido su propia existencia, también aporta de su sentido a la de los demás. De esta manera, se dan a la sociedad los dones esenciales de cada persona singular en un intercambio de aceptación donal. En consecuencia, en coexistencia con otros, el ser personal habita el mundo, conforma sociedad y crea cultura.

Con esta propuesta antropológica del sentido personal con base en la Antropología Trascendental de Polo consideramos que se puede contrarrestar la situación actual del hombre masificado, ya sea por las estructuras políticas o por 
Persona y sentido: la tarea esperanzada más allá de la felicidad

las económicas, o también por la irracionalidad tecnológica que se traducen en vaciamiento de sentido de su vida. Mas aún, en este vaciamiento de sentido personal en el ámbito esencial cabe la posibilidad de que también primero se haya obturado el sentido personal que deja de buscar su propio origen y destino para volcarse en lo que les inferior.

Como contrapunto del vaciamiento de luz personal en el entramado de las múltiples relaciones que se abren en la esencia del hombre, sobreviene, por una parte, el extrañamiento de sí y de los otros, por la no aceptación de sí mismo y los demás como personas, por otra, la extrañeza de habitar un mundo que parece ajeno a ser humanizado. Con esto sobreviene la angustia a causa de la soledad propia del hombre que, al olvidar quién es, se olvida también de humanizar. De modo que, procurar la transparencia interior para dotar de luz personal todos los ámbitos humanos se traduce en el desafío primordial de mantener una existencia con sentido personal:

El gran reto de la hora presente es configurar un modo de existir las personas en libertad evitando un equívoco siempre pronto a aparecer. En rigor, ser libre equivale a coexistir. La persona es el ser coexistente, no el independiente. La pretensión de independencia acaba convirtiendo al hombre en elemento de una estructura funcional anónima. El producto de la insolidaridad básica no puede ser otro que ese. La independencia termina en la masificación, es decir, en la multitud amorfa de suyo y configurada desde fuera. (Polo, 2015, p. 66)

\section{El ser esperanzado y su tarea}

El hombre no solo busca su felicidad a modo de satisfacción de sus deseos sensibles o los anhelos de su esencia o acrecentamiento inmaterial de sus potencias superiores, sino que más allá de tender al bien para adherirse a él con la consecuente felicidad que este conlleva, el ser humano es un buscador libre y aceptante-donal de su sentido, es decir, un ser esperanzado que busca ser aceptado y dar. Por tanto, aunque su existencia esté transida de sufrimiento, lo que opacaría la concepción de felicidad, su sentido no reposa en ello, sino en ser amado y amar. En ser de sentido que busca, que va a más sentido, hasta el encuentro con 
su Origen, mientras que dota de luz personal el mundo en su situación temporal en la histórica. En realidad, se trata de un ser que, como escribe Polo (2015), es "futuro no desfuturizable":

La existencia humana culmina en la correlación de nuestro ser en cuanto que está en el tiempo con un extremo suyo que lo desequilibra. El ser temporalmente equilibrado se extingue. Pero cabe un desequilibrio por exceso, que permite una apertura dirigida a la trascendencia. Trascender no es lo mismo que la intemporalidad, cognoscitiva, sino algo más, a saber, el futuro que está más allá de hacerse pasado. Lo llamaré futuro no desfuturizable. Es el destino de la libertad. (p. 7l)

Suele entenderse la felicidad como perfeccionamiento virtuoso al modo clásico. Cuando Aristóteles habla de la areté teleia (Polo, 2015) la define en relación con la felicidad, en la Política escribe: "cada uno participa de la felicidad en la medida de la virtud. La felicidad es el telos del hombre" (Aristóteles, p. 1326). Con esto no solo se trata de adherirse a lo bueno, sino de serlo a causa de sus acciones buenas, lo que es superior a la vida buena, porque se refiere a un fin: "se puede decir areté teleía porque solo en términos de virtud se puede ser feliz; cada uno es capaz de felicidad en la medida de la aretê" (Polo, 2015, p. 107). Según esta comprensión, el hombre dimensiona la relación con la felicidad a partir de que el bien elegido sea poseído.

Por su parte, Tomás de Aquino añade que la felicidad solo es completa si el bien poseído no se pierde, porque perder el bien significa perder la felicidad, por esto, hay mayor felicidad según sean más altos los bienes poseídos: "lo único que al hombre puede hacerlo feliz es el bien imperecedero, y por tanto inmaterial. El bien tiene que ser infinito, espiritual y eso es Dios" (Polo, 2018, p. 232). La concepción clásica de felicidad denota que el bien se posee:

la situación psicológica se corresponde con la posesión del bien deseado. Ese bien se desea por encima de cualquier otro o se considera suficiente. Por tanto, es claro que la noción de felicidad equivale a la de situación de equilibrio preferido. (p. 232)

Pero Polo plantea un problema ante este equilibrio preferido o deseado, a modo de comprensión de un sistema cuyo equilibrio parece ser la clave de la felicidad que busca. El problema consiste en que el mismo sistema puede estar errado, pero el 
Persona y sentido: la tarea esperanzada más allá de la felicidad

problema radical es que se trata de un sistema libre, no determinado para permanecer en el equilibrio que busca. Por esto, por una parte, afirma que la ética es capaz de regularlo. Por otra, describe así el problema:

el estado preferido por un sistema, si el sistema es libre, puede ser erróneo: eso es lo mismo que decir que la noción de felicidad depende de las mismas características del sistema. En efecto, un sistema libre no tiene en el tiempo un estado de equilibrio permanente. Es el sistema más dinámico y, por tanto, más abierto al futuro. (p. 231)

A partir de que el ser humano es un sistema libre, entra en juego la ética, porque "la ética se ocupa de reducir la inseguridad mejorando la capacidad evaluativa de las situaciones positivas de equilibrio. Esta mejora es necesaria para la consistencia del sistema libre" (p. 231).

En suma, más allá de que la felicidad se busque como un sistema de bienes equilibrado, no conviene olvidar que el hombre es libertad. Solo así se introduce correctamente en la concepción de felicidad una noción plenamente ética: la noción de bien. Por esto, cabe entender la ética sin reducciones de vertientes, sino como "una ética de bienes, de normas y de virtudes" (p. 233).

Pero, por encima de la ética, del obrar del hombre, no conviene olvidar que el buscador de sentido, más que "tener" el bien y mantener el equilibrio felicitario, sale al encuentro del sentido de su "ser"; como consecuencia, se trata de un sentido que mantiene su capacidad de dar, aun cuando en la búsqueda le sobrevengan la contradicción y el sufrimiento. Así que, aunque el deseo de felicidad parece excluir el sufrimiento, cabe reconocer que este acontece en el hombre, en ocasiones sin buscarlo, pues de este modo sería un sufrimiento inútil o inventado. Aun así, el sufrimiento real surge precisamente de la contradicción del bien deseado. Así que la felicidad entendida como un equilibrio a conseguir, lo margina, puesto que, si se sufre, no se es feliz. En consecuencia, se precisa reconocer un ser personal capaz de descubrir sentido en el sufrimiento.

Por consiguiente, afirmamos que si la felicidad, en la comprensión tradicional, depende de la consecución del bien deseado, esto solo no es suficiente para alcanzar felicidad, se requiere de la apertura radical luminosa capaz de dotar de 
sentido toda realidad vital para que ningún rescoldo de ella quede despojado de la posibilidad de ser humanizada:

no basta con que exista lo que al hombre le puede hacer feliz. Hace falta también que el hombre sea capaz de ser feliz. Son dos consideraciones coherentes: una sola no basta, no es suficiente. Es preciso que el sistema libre sea capaz de alcanzar sin oscilaciones su estado de equilibrio supremo. (p. 234)

De aquí que comparezca el buscador de sentido. En efecto, se precisa entender una apertura superior a la de las potencias inmateriales que configuran la "esencia" del hombre. Tal apertura es la del "acto de ser" personal, que no desea aquello de lo que carece, sino que, como intelecto abierto a más sentido, busca y descubre; y como es amar se desborda efusivo. De este modo es capaz de dotar con su luz libre a su existencia, incluso al sufrimiento:

El que no seamos enteramente felices no quiere decir que la felicidad no exista desde el punto de vista del bien; sin embargo, la felicidad podría no existir si yo fuese incapaz de ser feliz, pues para ser capaz de ser feliz, admitido que existe el bien supremo, es menester que yo no solo me dirija a él o me lance hacia él con el deseo, sino que cuando esté en su presencia esa conjunción sea tal que yo no pueda tener por mi parte ningún temor a desistir, a desdecirme, desprenderme o aburrirme. (p. 232)

De acuerdo con lo anterior, se puede afirmar, por un lado, que la virtud, como tener de perfección de la voluntad adherida a bienes superiores, forja un modo de aceptación de la realidad esencial, no solo del bien sino del sufrimiento del que está transida la existencia; por otro lado, que las tareas que el hombre realiza en su existencia temporal, cualquiera que ella sea, si están atravesadas de su sentido personal, es decir, si se hace de ellas un don amoroso, son también oportunidad de crecimiento interior, de humanización esencial, y aun de trascendencia. Según esto, no es cuestión solo de ser feliz sino de la capacidad de ser con y para otros amorosamente. Se trata por tanto de un juego de dones en el que el don no es mero resultado de un sistema felicitario o en equilibrio, sino que cada quien mediante sus dones esenciales se relaciona con el habitar del mundo físico, con los destinatarios inmediatos y con el destinatario final a quienes los ofrece y con las acciones que acomete para darlos: 
Persona y sentido: la tarea esperanzada más allá de la felicidad

La acción poiética no es solamente una continuación de la naturaleza del hombre, ni un mero resultado, sino que ha de referirse a destinatarios. Estos son: el universo material, al que perfecciona o deteriora; el actor, que se compromete en la acción y es afectado positiva o negativamente por ella; el beneficiario, que son otras personas humanas, para las que la acción es provechosa o nociva; Dios, que es quien encomienda al hombre el hacer, a quien puede - y debe- ser ofrecido, y juzga su valor en última instancia, aceptándolo o no. (Polo, 2015, p. 289)

Por eso, más allá de dar cuenta de su propio ser, el ser personal humano busca destinarse a su Origen, es decir, al Ser Personal del que procede como novedad radical. Pero, a su vez, él mismo es origen de las novedades teóricas y prácticas que aporta a otros destinatarios. En la dualidad de destinarse y destinar dones radica el sentido con el que el hombre dota su biografía. Esta nota de Polo (2015) lo aclara:

Destinarse el núcleo radical personal es trascenderse. La vida está radicada, el vivir no es ya el ser de los vivientes, sino que hay algo más radical y real que el vivir en acto, aunque esto no significa abolir el radical clásico, sino que lo profundiza. Trascenderse, que es característico de la persona como sujeto de actos, como la radicación de la vida no en una sustancia o en una naturaleza, también abarca la dimensión productiva. La vida como despliegue activo de capacidades es ahora la efusión de la radicalidad personal creada y, por tanto, en tanto que creada, estrictamente nueva. Esa novedad es mucho más radical, más nueva. (p. 227)

En suma, se muestra aquí que desde su intimidad radical el ser que es novedad se vuelca para manifestarse en su esencia. Así que el ser humano, en tanto que buscador de sentido, es otorgante de su luz amante hasta atravesar el plexo de ámbitos esenciales a los que se abre durante su existencia en el tiempo, para aportar hacia afuera sus dones amorosos que dependen del respaldo del ser personal amante. Esta dependencia evidencia la radicalidad del núcleo personal como acto de ser del que se deriva toda acción humana. No se confunde así la acción voluntaria libre con la libertad trascendental constitutiva del ser personal, ni tampoco la luz intelectual de nivel trascendental con la intelectiva propia de la razón: "la persona es raíz y fin de las demás dimensiones humanas, lo cual indica que no se 
puede arrojar suficiente sentido humano sobre las menores a menos que se alcance suficiente luz personal sobre la superior" (Sellés, 2007, p. 5).

Por esto se puede afirmar que el ser personal es pura novedad esperanzada en acto que, a más aceptación de más sentido personal, mientras está insertado en la historia, más dota de sentido su tarea esencial y con ello, dota de novedad su propia existencia y al mundo: "con lo cual llegaríamos a una conclusión: que la libertad es efectivamente una capacidad de autodeterminación” (Polo, 2015, p. 263).

En definitiva, el ser humano es un ser personal esperanzado porque es futuro que no se desfuturiza, es decir, capaz de destinarse al Sentido Originario, en relación amorosa por la que dota su vida temporal de sentido a modo de tarea esperanzada. Así contrarresta el vacío existencial de una vida sin propósito personal. Incluso, se descubre el sentido de su existencia en la historia a la que aporta dones mediante su trabajo, puesto que en él cabe descubrirse como dador de sentido:

El sentido del trabajo es distinto cuando el hombre se acepta como hijo y cuando rechaza esa condición. Para el que se sabe hijo, el trabajo es una tarea siempre referida a una encomienda a la que responde al tratar de realizarse como hombre (se desarrolla en el seno de la virtud de la piedad). Para el que rehúsa su condición filial, el trabajo es la colmación de un interno vacío: atribuye al trabajo el valor de una autorrealización como puro resultado. (Polo, 2015, p. 457)

Por esta tarea esperanzada, dotada de propósito personal, la persona humaniza el mundo en cada uno de los ámbitos en los que se manifiesta en sociedad. Con todo, esta actividad humanizadora implica por lo menos dos cosas: una, superar el paradigma del optimismo ingenuo, así como conjurar el pesimismo; y otra, regirse por la ética personal.

Por lo pronto, respecto del optimismo, cabe aclarar dos posibilidades, el que mueve a abrirse a más realidad o el que paraliza. Así lo explica Polo (2015):

Me parece que es inglesa aquella irónica sentencia que dice: "El optimista es el que sostiene que vivimos en el mejor de los mundos posibles; el pesimista es el que se lo cree". Según esto, hay dos tipos de optimistas. El primero admite que este es el mejor mundo posible: es el "optimista cándido" (Voltaire). El segundo es el optimista no cándido; 
Persona y sentido: la tarea esperanzada más allá de la felicidad

aquel que mantiene la tesis contraria: "no estamos en el mejor de los mundos posibles, y, por tanto, podemos mejorar". (p. 366)

De modo que el optimismo que dispone a ir a más mejora humana responde a una actitud libre que manifiesta al ser esperanzado abierto al futuro, puesto que no cabe esperanza sin optimismo que mueve a la tarea:

La primera dimensión de la esperanza es el optimismo. La esperanza lleva en sí optimismo; y también, al revés, el único optimismo legítimo es el que mora en ella. El pesimismo encierra y paraliza. En cambio, el hombre esperanzado camina hacia lo mejor, sale del ensimismamiento y se pone en tarea; sale de sí, ex-siste, precisamente porque su aportación prolonga su intimidad. Por su parte, un optimismo sin esperanza es trivial y enajenado. (Polo, 2015, p. 238)

Por lo anterior cabe afirmar acerca del ser esperanzado que no busca saciarse, sino amar. En consecuencia, su búsqueda no es de algo, sino de alguien; no es para tener, sino para ser aceptado y dar. No se trata de una búsqueda de felicidad que pueda frustrarse, sino de la pura actividad de luz amante abierta al futuro que supera la historia. Se supera así el deseo de satisfacción por el de donación. En esto radica ser sentido personal volcado libremente en coser:

El optimismo de la esperanza es precisamente el del ser insatisfecho. La esperanza implica insatisfacción, y en eso radica su peculiar optimismo, que es el auténtico. Un optimismo satisfecho es tan ridículo como dormirse en los laureles, y como no va seguido de algo mejor se marchita. Seguramente, todos hemos tenido la experiencia del esfuerzo hacia una meta. Una vez alcanzada, el que pretende instalarse en ella nota enseguida la desgana, un cierto disgusto. El optimismo del hombre que vive en esperanza es insatisfecho porque nunca se reduce al presente. (Polo, 2015, p. 238)

En efecto, el optimismo muestra una dualidad de la esperanza que se manifiesta: por un lado, en el ser que se destina a un sentido personal superior; por otro, en el ser que es capaz de realizar la tarea esperanzada. Lo primero, destinarse, es orientación libre del propio acto de ser; lo segundo, la tarea, es la respuesta libre aportante del ser personal a través de su esencia. Por consiguiente, en ningún caso se trata de un ser estático, sino por el contrario, del ser que es pura actividad, es decir, del acto ser personal, capaz de superar el tiempo y de transformar el mundo: 
El optimismo ante la situación presente es superficial y precario: es el optimismo del instalado; no el de quien está en tarea y en destinación, sino del satisfecho: un optimismo vacío de promesas, alienado en lo inerte. Como ya he dicho, el satisfecho es el que considera que es bastante lo que ha hecho (satisfacere) y, por tanto, descarta el mejorar, la novedad de la aportación. (Polo, 2015, p. 238)

En suma, se puede afirmar que el optimista activo es quien dota de sentido porque se dedica a la tarea de transformar la realidad temporal para mejorarla, porque "existir y estar en la esperanza es lo mismo. Sistere-extra, estar en la salida, implica abandonar justamente la inmovilidad” (Polo, 2015, p. 238).

En consecuencia, el ser esperanzado es agente de cambio porque humaniza el mundo al dotarlo de su luz mediante su tarea esperanzada, dotada de su sentido personal. Así también el mundo se abre más allá del presente, así se concreta el futuro desde ya para optar por una visión posible de un mundo más humano, pero esto implica abrirse más allá de sí, del aquí y del ahora, "de modo que la esperanza está integrada por un optimismo referido al futuro. Incluye un ponerse a prueba: salir de la situación presente en busca de otra. En suma, el que vive en esperanza afirma que estamos en un mundo mejorable" (p. 238).

De lo anterior cabe destacar que al optimismo se suma la tarea esperanzada. Es una de las dos vertientes de la esperanza por las que el ser humano se sitúa en la historia según su capacidad donal. Esta mirada es antropológica, no analítica, puesto que, "la entera 'estructura' de la esperanza se obtiene no del análisis de la noción, sino de su integración en el hombre, es decir, atendiendo a las dimensiones humanas que concurren en el existir según la esperanza" (Polo, 2015, p. 251). Así que la esperanza es constitutiva de la persona puesto que él es futuro que no se desfuturiza, debido a la pura actividad íntima o libertad que es y por la que se orienta a su destinatario final. Pero también, la esperanza se concreta en la esencia del hombre como optimismo aportante a la tarea. Por consiguiente, la esperanza atraviesa toda actividad humana en la que se ve el aporte personal como don: fundar familia, educación, trabajo, productividad, conformar cultura y el 
intercambio social. Con esto, los tres pilares de sentido se hacen posibles en la sociedad.

En definitiva, se puede comprender la novedad de cada quien desde sus aportes en la historia, o también comprender el significado de estas como manifestación singular del sentido personal. De este modo, se puede afirmar la novedad del sentido personal, como luz "atravesante" de toda realidad humana, que la transforma en una mayor posibilidad de humanización, así evita su caducidad, o más bien, la supera. En consecuencia, no se queda la persona humana presa del pasado: sino que es siempre un ser que va a más.

La persona irrumpe en la historia como la novedad más estricta, y en la medida en que la libertad es algo más que dominio de actos, la libertad es ahora personal (Polo, 2015, p. 228).

Con todo, en la tarea esperanzada cabe la pregunta del para quién se realiza la existencia, en esto radica realizarla en esperanza, puesto que como no cabe tarea sin riesgos ni recursos, vale la pena orientarla a un sentido superior por quien superar los desafíos. Así que la tarea no es posible sin que exista el "para quién" del logro, y aún más, implica a quien la ha encomendado realizar. Todos estos rasgos manifiestan la apertura luminosa en reciprocidad de aceptación y donación amante del sentido personal, el de cada quien en singular, que, como luz iluminante de lo esencial, en ella descubre, acepta y da a modo de aportación.

Se recalca a este punto que sin el aporte singular humano en la tarea esta no sería real ni esperanzada, sino vaciada de sentido personal; en consecuencia, no cabría el futuro para el hombre, entendido como una situación libre de progreso humanizado, sino una situación inventada o incluso fatalizada por su deshumanización paralizada en el presente: “esta esperanza falsificada - por quedar hueca del otorgamiento humano, de la actividad donante del hombre- es justamente lo que se llama utopía" (Polo, 2015, p. 241).

En suma, es importante subrayar hasta aquí, para la mejor comprensión del sentido personal que permea la tarea de existir, que en la situación temporal el hombre 
realiza su tarea y la dota o no de sentido según sea la calidad de su aporte como don amoroso de esperanza. Acorde con esto, el ser personal es capaz de ascender lo temporal orientándolo a su origen como posibilidad de ofrecimiento fuera del tiempo, pues él mismo no es del tiempo, sino puro sobrar de luz trascendental. De este modo, el ser personal "engarza" su realidad trascendental como acto de ser, con la realidad temporal en la que realiza su existencia:

El hombre solo puede salir en el tiempo del tiempo mediante la esperanza, que no es un mero aguardar - llegará lo que tenga que llegar orientado intratemporalmente- . Por el contrario, la esperanza enlaza con el extremo del tiempo: es un "sobrar" que el tiempo no gasta. (Polo, 2015, p. 71)

De aceptarse lo anterior, se puede afirmar que el ser personal es "dar" capaz de vincularse a su origen fuera del tiempo; por esto se "enlaza" con el extremo del tiempo, aunque desde él se vuelva dentro del tiempo al ámbito en el que realiza su tarea esperanzada. Se sitúa así entre ambos, entre el encuentro con su Origen motivo de su esperanza, y la realización de su propia biografía con la que teje su itinerario de dotación de sentido humano dentro de la historia:

El hombre es en el tiempo, pero en él se abre más allá. La cuestión no es si hay más realidad que la temporal, porque para ello basta el pensamiento - la presencia-, sino la posibilidad de que el hombre se abra en el tiempo al extremo del tiempo que no está en él, de manera que esa apertura no sea un mero seguir siendo en el tiempo, sino una culminación no acontecida y, por tanto, que supere la interpretación del tiempo como telar del ser. (Polo, 2015, p. 7l)

\section{El enlace del sentido personal con la ética}

En este punto interesa resaltar, acerca del tema de este estudio en relación con la persona, su sentido y la tarea esperanzada que, si por un lado el ser personal enlaza con su origen en su intimidad, por otro, enlaza con la historia por la ética. Así, sus dones se atraviesan de sentido personal dotados de amor que contiene la justicia. Debido a este modo de respaldar sus acciones, el ser personal se abre desde dentro de su propio núcleo de luz mediante el ámbito potencial para configurar sus acciones a modo de dones. Cabe retomar, que el conocimiento acerca de los actos humanos lo ilumina la sindéresis, como el modo de conocer de la persona 
para hacerse cargo de su existencia en el tiempo, lo que configura el ámbito del despliegue de la esencia del hombre, es decir, de su manifestación en la historia o de su realización biográfica, regida por la ética. De modo que la activación de la inteligencia y de la voluntad se origina en la actividad intelectual y amante del núcleo personal que se vierte hacia sus manifestaciones potenciales. Así, las acciones que el ser humano acomete se rigen por la propia condición de ser sentido personal, de aquí su estrecha vinculación ética; por esto, “es necesario formular la ética como una ciencia acerca del hombre" (Polo, 2018, p. 230).

De acuerdo con esto, el conocimiento ético resulta tan cercano al "dentro" personal que, por esto, se da la intrínseca inmediación del ser que cada "quien" es en el modo de actuar voluntario. El respaldo del núcleo personal, del intelecto amante que se es, reafirma la calidad amorosa donal de la acción voluntaria libre. A su vez, al ejercer su querer voluntario en actos amorosos, el ser humano se humaniza, crece por dentro. Así lo expone Polo:

El hombre es un ser complejo y unitario, abierto hacia afuera y desde dentro, que retorna a su intimidad y se trasciende: en este ir y venir se forma ise forja! Nada hay en él que se pueda considerar neutral desde el punto de vista ético, porque ninguna regla anónima, simplemente racionalizada, es capaz de explicar ese coexistir que integra lo externo en lo interno y otorga lo interior a lo exterior, de acuerdo con el cual se forja, como digo, lo humano. (Polo, 2018, p. 71)

Por consiguiente, de las acciones humanas se destaca que en tanto que estén dotadas de verdad y de amor, están atravesadas de sentido personal y, por tanto, son éticas. De modo que no cabe escisión entre lo que le es propio al ser personal, su ser constitutivo como intelecto amante, y lo que manifiesta en sus acciones. Así mismo, el hacer ético responde al modo humano de estar de la persona en el mundo. En consecuencia, ninguna acción humana está al margen de la ética:

Enfocamos la ética como la dimensión intrínseca del ser humano dinámicamente considerado, entonces se evita la superficialización o parcialización de lo ético: esa alternancia u oscilación entre lo que es ético y lo que no lo es. Necesitamos un estudio de la ética que dé razón del actuar humano, que nos haga ver de qué manera surge una legalidad, una regularidad que tiene que ver con lo más elemental y lo más profundo del ser humano, y con su ascender las escaleras del ser. La ética es la ciencia antropológica 
que siempre hay que tener en cuenta, aquella de la que no se puede prescindir o dejar en suspenso. Una ciencia sin la cual el hombre se hace ininteligible, se deshumaniza. (Polo, 2018, p. 143)

Según la complejidad de ámbitos que la persona abre en la esencia y a los que dota de su sentido, vale la pena detenerse para escrutar de forma breve la índole de las acciones humanas. El ser humano actúa eligiendo medios que quiere como bienes; este querer el bien es el acto propio de la voluntad, pero antes, el bien como medio es mostrado por la inteligencia; esto coincide con los actos de la razón práctica. De esto se esclarece que según sea el actuar ético del hombre se abre un plexo de medios en los que es posible humanizar y humanizarse. Esta interacción recíproca entre el ser que se humaniza y el humanizar su aportación, establece la cohesión social. Por esto, cabe afirmar que

la consistencia de la sociedad civil es la ética. Esto se vislumbra, pero aún de modo prematuro. La ética, como la valoración, es intrínseca al hombre como ciudadano. Aparece, no como un invento o una revelación, sino como una dimensión constitutiva del hombre. (Polo, 2015, p. 72)

Ahora bien, tomamos de Polo que el plexo es una red de ámbitos de lo humano en el nivel esencial que se interconectan. Aportamos aquí que el enlace de unos con otros se concreta en la donación mutua de sentidos personales a modo de dones amorosos lo que ilumina el plexo y lo hace fecundo para creer. Así, aunque el ámbito de las manifestaciones intramundanas es complejo, su interrelación se hace también posible, según se orienten los medios al fin, que es el ser humano, y según se organicen los medios entre sí, hacia ese fin. Acerca de estos se puede aclarar lo siguiente:

Tomás de Aquino habla de los medios como partes. El medio total es justamente todos los medios, lo que no significa un amontonamiento, sino una organización. Sin la organización horizontal de los medios, se estropea la relación de los medios con el fin superior. Aislar los medios es una equivocación. (Polo, 2015, p. 433)

Acorde con esto, interesa notar en el plexo de medios, dos niveles propios de la acción, uno vertical y el otro, horizontal, que es preciso distinguir a fin de atender, por un lado, a la relación entre ellos y, por otro, a la claridad moral a la que 
Persona y sentido: la tarea esperanzada más allá de la felicidad

cada uno de ellos debe referirse. Aquí se presentan como "dos ordenaciones: la interconexiva, que requiere la interdisciplinariedad de las ciencias, y la ordenación superior, a la que debe atender la moral" (Polo, 2015, p. 234). Así mismo, si se atiende a que estas ordenaciones no son excluyentes, el plexo medial de la acción humana se amplía, es decir, dentro del marco de la dotación ética por la actividad libre de la novedad personal que la atraviesa, la acción humana se abre a la innovación: "los medios se organizan justamente porque son para el hombre, es decir, porque sirven para el fin. Pero, insisto, la ordenación vertical es difícil si no se atiende a la horizontal" (p. 234).

Ahora bien, si el orden vertical se refiere a que los medios son para el hombre, ien qué consiste el orden horizontal? Cabe atenerse a esta exposición:

Tenemos que aludir a los actos que preceden a la acción. El consilium es un acto de la razón práctica que presenta un conjunto de bienes mediales empezando a atender a su relación. Ese conjunto es variable, por lo que se ha de reorganizar. Estos actos se desarrollan con la deliberación, a la que sigue la elección; a la elección sigue el imperio; y al imperio la acción práctica. Por tanto, la organización de los medios es gradual y progresiva. (Polo, 2015, p. 234)

Por consiguiente, de aceptar que el fin de toda acción es el bien propio del ser humano, ya visto como el saberse sentido personal con la capacidad de donar de su sentido, se procede según el orden presentado de actos que llevan a la acción voluntaria. Aceptar que la acción humana es iluminada por la razón posibilita el uso de los medios según su fin: "el fin intentado ordena el plexo de los medios, y lo amplia" (Polo, 2015, p. 433). Sin este "cruce" de actos cognoscentes y volitivos no es posible establecer una jerarquía entre los medios elegidos para configurar la acción dotada de sentido y amor. Según esto cabe tener en cuenta esta afirmación: “siempre hay intención: no se actúa sin motivos" (p. 433).

En síntesis, la tarea es el medio por el que el ser esperanzado configura sus dones en la esencia humana. Por esto, el don como tarea revela al ser personal y su sentido iluminando la marcha de la historia, la orienta a su fin, al despliegue de lo humano, pues de otro modo, la fragmenta y la destruye. De manera que los dones de sentido esencial se otorgan mediante actos de la voluntad, en relación 
intrínseca con la inteligencia, por lo que se desvela el ser que es intelecto en coexistencia también en el tiempo. En consecuencia, la tarea donal está atravesada de sentido personal, es decir, de conocer, amar y libertad como trascendentales antropológicos.

Al tener esto en cuenta se descubren dos vertientes del sentido personal en la tarea esperanzada: una, el sentido con el que se dota luz amorosa y libre a la dinámica del mundo; otra, el sentido que se descubre a través de ella con la posibilidad de su ofrecimiento. Cabe, sin embargo, la posibilidad de lo contrario: si ni el fin ni el orden preceden a la acción:

El plexo de los medios se organiza de tal manera que hace imposible la intención que mira al fin, hay que decir que esa organización es incorrecta. Detener los actos voluntarios en el uso es una omisión obsesiva que paraliza el querer-más. (Polo, 2015, p. 434)

En definitiva, de vaciarse de ética, la acción humana no impulsa la dinámica libre de la sociedad por la que se humaniza, sino que, por el contrario, la paraliza, o aún peor, la deshumaniza. En consecuencia, la acción humana volcada solo en lo útil o productivo del resultado no contribuye a mantener los ámbitos sociales abiertos por el hombre como agentes de sentido personal.

\section{Discusión}

Según lo expuesto se puede afirmar, a partir de las claves identificadas en la antropología de Polo para aclarar el tema en discusión, se propone una antropología que entiende el sentido personal como radicalidad. Se presenta así, por una parte, que la actitud esperanzada es propia del buscador que es y da sentido personal a la existencia humana en el tiempo; por otra, que la esperanza aplicada a la tarea existencial contribuye a configurar y humanizar los ámbitos humanos que se erigen como agentes capaces de dotar de sentido humano a la sociedad. Una y otra dimensión de la esperanza, tanto la propia del acto de ser que lo abre al futuro, como la que se manifiesta en la acción esencial para perfeccionarla, constituyen los aspectos relevantes del mejoramiento ético de la sociedad. Según esto, la actitud del ser humano coincide con la del optimista auténtico, porque "considera 
Persona y sentido: la tarea esperanzada más allá de la felicidad

que los problemas son retos y que las soluciones dadas no son suficientes: los retos reclaman la capacidad de innovar" (Polo, 2015, p. 33).

De manera que la humanización de estos ámbitos se enraíza en la acción humana que humaniza el mundo porque lo abre a más sentido. Con esto, la acción del hombre manifiesta el intelecto libre y amante que es. Sin embargo, el hombre puede retraerse a lo inferior para actuar solo según la mera tendencia, como si no se tratara de un espíritu libre a cargo de habitar el mundo haciendo cultura:

El mundo humano solo existe si es activado. La activación es el empleo de la acción humana: si la acción humana lo desasiste, el mundo se desvanece. El hombre tiene que ejercer su acción respecto del plexo para darle existencia, pero si se reduce a ello, queda atrapado por su mundo. Por tanto, lo primero que tiene que asegurar la organización del mundo es la conservación de la libertad personal respecto de él y en él; el hombre no puede agotarse en su uso del mundo. Desde este punto de vista, el hombre es un ser histórico. El mundo humano es susceptible de cambios. (Polo, 2015, p. 325)

Lo contrario del progreso vinculado a la personalización de los ámbitos humanos consiste en decaer en un proceso de regresión humana en la que no cabe considerar el ser humano como proyecto. Esta condición radical del ser personal como proyecto que realiza tarea existencial abre el mundo al futuro.

Por esto se precisa subrayar en esta discusión el embate de la adversidad en la existencia del hombre en la historia. Interesa por esto el enlace entre el conocimiento por el que la persona se hace a la compleja realidad humana en su situación histórica, con la capacidad de dotarla con su luz mediante la realización de su tarea esperanzada, es decir, se presenta al hombre como ser personal capaz de afrontar la adversidad y superarla; esto, si el hombre no se olvida de quién es, persona, y de cuál es su origen y su destino, desde lo que es capaz de dotar de sentido su existencia:

El destino del hombre podría ser la catástrofe, debido a la incomprensión de la complejidad creciente del mundo: esa posibilidad está abierta. Sin embargo, también está abierta la contraria. En la historia han sucedido grandes calamidades que la humanidad ha aguantado y no le han impedido reanudar su marcha. Hoy percibimos el riesgo de 
deshumanización de forma muy aparatosa: pero la línea positiva está clara. (Polo, 2015, p. 326)

Esto lleva a considerar como parte de la discusión la calidad del aporte humano, puesto que, según sea la densidad de sentido personal amoroso con el que se dota el aporte humano, se proyecta o no un mundo más o menos humano. De aquí la importancia del carácter esperanzado de la tarea existencial:

Lo más característico del ser humano es que puede ir a mejor y también a peor. Se puede ir hacia un mundo más humano y también hacia un mundo menos humano. Aceptar esta última tesis es lo propio del optimista auténtico; se nos brinda la posibilidad de mejorar. (Polo, 2015, p. 364)

En síntesis, se trata de una propuesta antropológica en la que cabe alcanzar el propio sentido personal, así como atravesar de sentido la existencia del hombre en el mundo, porque en ella el espíritu libre se abre al futuro:

El signo de nuestro existir, su destino, o como se le quiera llamar, es el reforzamiento de la dignidad de la persona. La evolución es como una preparación para la aparición del ser espiritual. El ser espiritual produce un mundo, y ahí es donde juega su batalla. (Polo, 2015, p. 325)

\section{Conclusiones}

En este trabajo se ha presentado a la persona humana como acto ser de sentido capaz de abrir con su tarea existencial la sociedad y dotarla de su luz amorosa. De momento se concluye lo siguiente.

En primer lugar, la Antropología Trascendental de Polo (2015) contribuye a ahondar en la comprensión del ser humano hasta alcanzar lo constitutivo de su ser en los trascendentales antropológicos, es decir, ser un intelecto de nivel trascendental, coexistente, libre y amante. En segundo lugar, a partir de sus aportes se continúa la investigación con este estudio sobre la persona y su sentido que propone entender la persona humana como un núcleo de sentido inagotable que busca más sentido personal a la vez que lo da. Por consiguiente, más allá de su anhelo de felicidad, la persona es un esperanzado, abierto al futuro. Si lo propio del ser humano es su radicalidad como persona, así también, en su existencia en 
el tiempo realiza su proyecto humanizador mediante su tarea esperanzada, como don amoroso, con el que dota de sentido la sociedad. Con ello también aporta carácter humanizante a la marcha de la historia. En tercer lugar, la ética se constituye en el cauce humanizador mediante el cual el sentido personal se concreta en las acciones voluntarias. Por una parte, la ética cohesiona la sociedad, por otra, la preserva de la posibilidad de deshumanizarse.

Por tanto, más allá que buscar la felicidad, el ser humano busca el sentido de su ser en el encuentro con otros sentidos personales. Así mismo, el ser humano busca dotar de sentido personal su estar temporal en el mundo, porque, aunque la existencia humana esté transida de sufrimiento, y así, ante el mundo la felicidad no resulte del todo alcanzable, su búsqueda de sentido sí se concreta en la aceptación de la verdad personal que es y en el dar de su luz a través de sus actos verdaderos y amorosos con los que ilumina la historia. De este modo, la persona humana manifiesta en su biografía el amar del que proviene y del que ella misma es capaz. Esta es la radical consistencia del sentido personal que como acto de ser nutre la tarea esperanzada y, tal vez, sea también el modo como en la existencia humana tenga cabida la anhelada felicidad.

\section{Referencias}

Aristóteles. Libro primero: origen del estado y la sociedad.

Hernández, R., Fernández, C. y Baptista, P. (2006). Fundamentos de metodología de la investigación (3. a ed.). McGraw-Hill.

Madé, N. (2006). Metodología de la investigación (p. 69). Ciudad de México: Editora Mac Graw Hill.

Polo, L. (2015). Filosofía y economía. En Obras Completas, serie A, vol. XXV. Pamplona: Eunsa.

Polo, L. (2015). La originalidad de la concepción cristiana de la existencia. En Obras Completas, serie A, vol., XIII. Pamplona: Eunsa.

Polo, L. (2015). Persona humana y su crecimiento. En Obras Completas, serie A, vol., XIII. Pamplona: Eunsa.

Polo, L. (2015). Antropología trascendental. En Obras Completas, serie A, vol., XV. Pamplona: Eunsa.

Polo, L. (2015). Quién es el hombre. En Obras Completas, serie A, vol. X. Pamplona: Eunsa.

Polo, L. (2016). Presente y futuro del hombre. En Obras Completas, serie A, vol. X. Pamplona: Eunsa.

Polo, L. (2017). Persona y libertad. En Obras Completas, serie A, vol. XIX. Pamplona: Eunsa. 
Polo, L. (2017). Escritos menores (1991-2000). En Obras Completas, serie A, vol., XVI. Pamplona: Eunsa.

Polo, L. (2018). Antropología de la acción directiva. En Obras Completas, serie A, vol., XVIII. Pamplona: Eunsa.

Polo, L. (2018). Ayudar a crecer. En Obras Completas, serie A, vol. XVIII. Pamplona: Eunsa.

Polo, L. (2018). Ética: hacia una versión moderna de los temas clásicos. En Obras Completas, serie A, vol. XI, Pamplona: Eunsa.

Polo, L. (2019). El hombre en la historia. En Obras Completas, serie A, vol. XVIII. Pamplona: Eunsa.

Sellés, J. F. (2007). Antropología para inconformes. Madrid: Rialp.

Sellés, J. F. (2013). Los tres agentes del cambio en la sociedad civil: familia, universidad y empresa. Madrid: Eunsa. 



\section{3 \\ Felicidad, empatía y solidaridad personal frente al trauma sociocultural de la pandemia en Italia*}

\section{SANDRA Ligia RAMÍREZ-OROZCO**}

La felicidad es como una mariposa, cuanto más la persigues, más te eludirá. Pero si vuelves tu atención a otras cosas, vendrá y suavemente se posará en tu hombro.

Henry David Thoreau

\section{Resumen}

La aparición en 2020 del coronavirus, enfermedad infectocontagiosa, generó una pandemia, marcada por un antes y un después para el mundo actual. Es una enfermedad que no excluye a nadie y representa un desafío para la comunidad global similar al de una guerra armada, pero con un enemigo invisible que genera angustia, ansiedad, incertidumbre y desesperación.

Italia, país europeo golpeado de forma sorpresiva y abrupta por este virus sufre, como describe Alexander (2016), un trauma sociocultural, este significa aprender lecciones importantes para la esfera civil, una de ellas es vivir y sentir la solidaridad como lo describe Alexander (2006) a través de la manifestación de los

\footnotetext{
* El siguiente escrito es producto del proceso de investigación para el Doctorado en Sociología, Teoría e Historia de las Instituciones de la Universidad de Salerno (Italia).

** Docente investigadora del Departamento de Humanidades de la Universidad Católica de Colombia. Grupo de investigación Philosophia Personae. Abogada, magíster en Ciencia Política, doctoranda en Sociología, Teoría e Historia de las Instituciones, Università Degli Studi di Salerno. slramirez@ucatolica.edu.co https://orcid.org/0000-0003-2953-878X
} 
valores de las personas y los apoyos institucionales que le permitan a la comunidad compartir entre sí las experiencias traumáticas de la pandemia.

Este estudio se desarrolla dentro de un enfoque interpretativo y analítico, lo cual le da un carácter cualitativo a la investigación. Las técnicas de recolección de la información se obtienen a través de testimonios, fichas de estudio documental y la revisión de las experiencias vivenciales desde diferentes escenarios de la esfera civil.

El objetivo propuesto con esta investigación, que a la vez hace parte de una vivencia personal, es la búsqueda de elementos comunes experienciales que acerquen a la comunidad entre sí de forma empática, la interacción con el otro y sentirse como el otro para así reconstruirse colectivamente. Es así que los procesos de reconstrucción individual y colectiva deben estar permeados por la solidaridad personal y comunitaria, enfocados de forma objetiva para trabajar sobre la conciencia social y las estrategias gubernamentales que generen un ambiente de felicidad y armonía.

Palabras claves: trauma sociocultural, pandemia, solidaridad personal, empatía, felicidad.

\section{Introducción}

El año 2020 marca la historia de la humanidad por la vivencia colectiva de una pandemia viral desconocida llamada coronavirus, que lleva a los gobiernos afectados, a nivel global, a tomar decisiones sin precedentes para enfrentar a este enemigo invisible. Los tiempos que se están viviendo son muy difíciles ya que se debe aprender a ver la vida de una forma diferente y relacionarse ya no será igual.

\section{Antecedentes}

Se hizo un rastreo bibliográfico y documental de investigaciones sobre las consecuencias que deja el trauma sociocultural de la pandemia COVID-19 en países como Italia. El origen del virus se da en la ciudad de Wuhan en China a finales de 2019; en un principio no se le dio la importancia que merecía y se pensó que no 
pasaría de ser una enfermedad viral estacional local, que no trascendería fronteras. A mediados de febrero de 2020 Italia, con más de 60 millones de habitantes según datos de Anagrafe y con un estilo de vida muy coloquial y fraternal, se vio inmersa en una expansión sin precedentes de este virus en la zona norte.

Italia padeció durante tres meses una pesadilla similar a las experiencias vividas durante las dos guerras mundiales, el país no estaba preparado para que un enemigo invisible atacara sin piedad a sus ciudadanos y comenzara una escalada absurda de contagios y muertes diarias, lo cual dejó a uno de los sistemas de salud más robustos de Europa sin argumentos para controlar una pandemia como la del COVID-19.

La definición de pandemia es reciente, a las enfermedades infectocontagiosas masivas como el coronavirus se les conocía como peste, el Diccionario de la lengua española (2014) define la peste como "enfermedad contagiosa y grave que causa gran mortandad". Desde la antigüedad, la humanidad sufre del flagelo de este tipo de enfermedades misteriosas que atacan de forma inesperada con resultados muy graves de contagios masivos y un número significativo de muertos.

El mismo diccionario define pandemia como "una enfermedad epidémica que se extiende a muchos países o que ataca a casi todos los individuos de una localidad o región". La Organización Mundial de la Salud (OMS) (2010) establece que "una pandemia de gripe es cuando surge un nuevo virus gripal que se propaga por el mundo y la mayoría de las personas no tienen inmunidad contra él".

La historia de las pandemias más significativas por su número de muertos para la humanidad como la describe Tomasi (2020) se remonta a la primera de la que se tiene conocimiento en Grecia en el año 430 a. C. a 426 a. C. con 250.000 muertos y se conoció como peste de Atenas; esta enfermedad se dio en un momento muy difícil ya que se estaba librando la batalla entre Atenas y Esparta por el control del Mediterráneo. La peste de Atenas era desconocida para la época y los médicos no podían hacer nada y morían al tener contacto con sus pacientes, se piensa que se asemejaba a la fiebre tifoidea. 
Luego y en diferentes lugares del mundo se dieron otras 19, entre las que se pueden resaltar la peste negra o bubónica que se originó en Asia Central en el año 1347 con 200 millones de muertos, la más grave hasta la actualidad.

La peste negra se mantuvo vigente hasta 1837 y el foco de contagio eran las pulgas que habitaban en las ratas y de allí las picaduras de las pulgas a los humanos; se considera que se expandió en continentes como Europa en los barcos mercantes. Es importante tener en cuenta que en la Edad Media y hasta mediados del siglo xx las ratas fueron una plaga difícil de controlar y para la época de esta pandemia abundaban (Tomasi, 2020).

En consecuencia, durante siglos la peste negra o bubónica fue una de las enfermedades más temidas, por su alto nivel de contagio y las pocas posibilidades de sobrevivencia para la época.

La segunda peste más mortífera después de la peste negra fue la de la viruela en 1520 con 56 millones de muertos, se considera que durante los procesos de conquista y colonización se importó la enfermedad de Europa a América y se calcula que el 90\% de la población nativa de América murió por esta dolencia. Por último, la pandemia más reciente y significativa por el número de víctimas es la gripe española entre 1918 y 1919 con 50 millones de muertos (Tomasi, 2020).

La gripe española se da durante la Primera Guerra Mundial como consecuencia del virus letal de la gripe, con sistemas de salud débiles y sin medicamentos adecuados para combatirla. Todas las pandemias vividas por la historia de la humanidad han sido de gran trascendencia y devastadoras por sus consecuencias, pues han atacado a un número importante de la población. Los gobiernos se debaten entre salvaguardar la vida de los ciudadanos y proteger los sistemas económicos que se ven golpeados por la emergencia sanitaria, esto repercute directamente en la inestabilidad social y económica de los países afectados.

En un pensamiento general se creía que este tipo de pandemias expansivas a nivel global habían quedado en el pasado, se confiaba en los avances de la ciencia 
y la tecnología de la actualidad, se pensaba que el mundo estaba preparado para enfrentar cualquier tipo de enfermedad infectocontagiosa y controlarla a tiempo, sin mayores consecuencias para la humanidad.

Lamentablemente, la historia reciente de la humanidad no es así y la aparición sorpresiva del COVID-19 nos dio una lección de humildad y reflexión a todos, incluso, el director de la OMS, Tedros Adhanom (2020), afirmó que los científicos, asombrados ante lo desconocido de esta enfermedad, su capacidad de rápido contagio y las muertes que ha implicado, advierten que pueden venir más pandemias iguales o más agresivas que esta, un interesante cambio en la visión científica de este fenómeno.

\section{Aportes y contexto}

Esta investigación hace un aporte sociológico y político al estudio del fenómeno personal y social de la pandemia COVID-19, que deja como consecuencia un trauma sociocultural que altera de forma significativa el estado de felicidad personal y de bienestar social para la esfera civil. La investigación se ubica en el entorno de la vivencia personal y convivencia social en su etapa más crítica en Salerno (Italia) de febrero a junio de 2020.

Es así como el acercamiento a la realidad de las experiencias vivenciales de la pandemia en Italia permite reflexionar sobre la importancia de la empatía desde el "yo" (persona), de forma que se proyecte a la solidaridad del "nosotros" (comunidad) y se genere la reconstrucción sociocultural de la esfera civil en conjunto.

Sobre la base de estos elementos queda claro que valores como la empatía y la solidaridad, tanto en sus niveles personales como comunitarios, no se dan en el mismo grado en todos los grupos sociales. A través del desarrollo de la investigación se pudo determinar que para sentirse en comunidad y reconstruir colectivamente desde adentro la esfera civil, influyen varios factores como son la cultura, la educación, la religión y la economía. 


\section{Metodología}

Esta investigación se desarrolló dentro de un enfoque interpretativo y analítico, lo cual le da un carácter cualitativo a la investigación. Se usó la recolección de datos enfocada en el descubrimiento e indagación del por qué y el cómo, de modo que se le diera prioridad a la interpretación cualitativa. Se escogió esta ruta debido a que se buscó encontrar sentido a los fenómenos según los significados otorgados por las personas involucradas en la investigación, también se anexa bibliografía complementaria tomando como autores de base Taylor y Bogdan (1989).

Las técnicas de recolección de la información se obtuvieron a través de rastreo bibliográfico, testimonios, fichas de estudio documental y la revisión de las experiencias vivenciales desde diferentes escenarios de la esfera civil italiana.

La información documental se obtuvo en instituciones seleccionadas de carácter público y privado, instituciones ubicadas en Roma como el Dipartamento de Protezione Civile a través de sus reportes diarios y la Presidenza del Governo del Consiglio dei Ministri con los informes oficiales emitidos por el Gobierno; y en Milán el Istituto di Ricerche Farmacologiche Mario Negri mediante los reportes de su director científico Giuseppe Remuzzi.

La metodología utilizada en esta investigación permitió el reconocimiento de elementos comunes experienciales de la comunidad durante la pandemia como son la soledad, el abandono, el miedo, el temor, la angustia, la ansiedad y la incertidumbre. Elementos que unidos entre sí ponen de manifiesto el trauma sociocultural que sufre la esfera civil durante la vivencia exponencial a esta enfermedad COVID-19, esto sin tener certeza de qué futuro positivo se puede construir.

La metodología se desarrolló partiendo del análisis del problema que representa el trauma sociocultural que deja la pandemia COVID-19 en la comunidad, de esta forma se pudo llegar a la consecución del objetivo de encontrar respuestas a elementos comunes de convivencia como la empatía y la solidaridad personal para reconstruir la esfera civil de forma conjunta. Y, finalmente, como resultado alcan- 
zar entre todos la armonía y bienestar común como componentes importantes de la felicidad personal.

\section{Resultados}

\section{Desarrollo de la pandemia en Italia}

Los primeros casos en Italia surgen a partir de una pareja de turistas chinos, su contagio fue confirmado el 30 de enero por el Instituto Lazzaro Spallanzani de Roma, posteriormente fueron hospitalizados y aislados hasta el 26 de febrero y debido a esto Italia bloqueó el 30 de enero todos los vuelos hacia China por 90 días.

El Gobierno nombró al jefe de Protección Civil, Angelo Borrelli, como comisionado especial de la emergencia. Se creó un comité técnico científico para orientar y guiar las medidas de prevención y control de la epidemia. Las primeras medidas establecieron el cierre de las áreas más afectadas en el norte del país (Lombardía, Emilia Romagna y Véneto) el 23 de febrero, luego, el cierre de las instituciones educativas y las actividades comerciales no esenciales; para el 10 de marzo el Ministerio de Salud y del Interior ordenó la cuarentena obligatoria nacional hasta el 25 marzo, luego hubo varias prórrogas consecutivas desde el 3 de abril, 13 de abril y 4 de mayo hasta el 18 mayo ante la gravedad de la expansión de la enfermedad declarada pandemia por la oms el 11 de marzo.

Al comienzo de la pandemia se sintió un abandono total por parte de la Unión Europea (UE) y se cuestionó dónde está el concepto de comunidad y solidaridad, principios rectores con los que fue fundada esta entidad geopolítica. Italia y España, los países más afectados por la pandemia, se unieron para luchar por un sentido más empático y solidario ante la dura y rígida posición de Alemania y Holanda para brindar ayudas económicas por parte de la UE a los países más vulnerables y necesitados.

Italia inició su fase 2 de reapertura en un intento gradual de normalizar la vida de sus ciudadanos el 18 de mayo de 2020, levantó poco a poco las medidas restrictivas 
para que los ciudadanos de forma responsable y consciente aprendieran a convivir con el virus y la economía del país se pudiera reactivar.

La gestión de la fase 2 de la pandemia en Italia se activó con un sistema de monitoreo específico, regido por el decreto del Ministerio de Salud del 30 de abril de sobre datos epidemiológicos y sobre la capacidad de respuesta de los servicios regionales de salud. El monitoreo lo lleva a cabo la sala de control establecida por el Ministerio de Salud, el Instituto Superior de Salud y cada una de las regiones.

La fase 3 inició el 3 de junio de 2020 y buscaba encontrar una propuesta de reconstrucción socioemocional, económica y política para la esfera civil italiana, esta pandemia se vive como una guerra con un enemigo invisible. En julio de 2020 Italia intenta recomenzar y reconstruirse poco a poco con el temor de que en cualquier momento el virus vuelva a atacar. Las estrategias y los métodos para este renacer todavía no son claros y existe confusión sobre lo que se debe hacer y lo que no. El primer ministro, Giuseppe Conte, fue citado ante la Fiscalía el 12 de junio de 2020 para dar explicación sobre las medidas tomadas para el manejo de la pandemia y exponer las estrategias que se tienen previstas para la reconstrucción de la "posguerra biológica" como algunos la han llamado, es decir, dar cuenta de hacia donde se van a encaminar las propuestas y esfuerzos del Estado.

La llamada fase 3 de reapertura y recomenzar la "vida normal" se vive en Italia de forma gradual, sin embargo, surge la gran preocupación de que, al reabrir el turismo extranjero como una de las principales fuentes de ingreso económico en Italia, el virus regrese y aparezca un rebrote. Cada día el Gobierno intenta controlar la pandemia que por ahora es estacionaria, pero se sabe que en cualquier momento podría regresar y el temor aumenta cada día.

\section{El trauma sociocultural de la pandemia en Italia}

Italia se enfrenta al COVID-19, el Gobierno y los científicos tienen el reto de diseñar y coordinar las estrategias que permitan superar esta catástrofe. 
El trauma sociocultural que deja la pandemia del COVID-19 compromete a los miembros de la colectividad de forma responsable y moral para determinar sus relaciones y apoyarse de forma solidaria y proactiva frente a la adversidad.

Un trauma cultural se produce cuando los miembros de una colectividad sienten que han sido sometidos a un acontecimiento horrendo que deja marcas indelebles en la consciencia colectiva, marcando sus memorias para siempre y cambiando su identidad futura de manera fundamental e irrevocable (Alexander, 2016, p. 193).

La vivencia actual de la pandemia del coronavirus a nivel mundial lleva a que las sociedades afectadas deban repensarse en sus relaciones sociales, de esta forma, pueden encontrar solidariamente los elementos vivenciales comunes que den las posibilidades de una reconstrucción socioemocional y económica a la esfera civil del trauma sociocultural. Las personas necesitan sentir de nuevo tranquilidad, bienestar, alegría y seguridad que sin duda conllevan al estado de felicidad ideal para todo ser humano.

\section{La empatía y la solidaridad personal de frente al trauma sociocultural}

La empatía como capacidad humana que lleva moral y solidariamente a comprender lo que el otro vive y siente, sin discriminaciones, humillaciones y ventajas, será un punto clave en este mundo tan heterogéneo para encontrar rasgos comunes que permitan la reconstrucción socioemocional, que al lograrse se verá reflejada en el bienestar común.

La empatía hoy recobra gran importancia a nivel global para enfrentar el trauma sociocultural que dejará la pandemia del COVID-19, dicha capacidad humana hace referencia al nosotros, no se puede hablar en plural si no hay ese acercamiento real a las vivencias del otro. La empatía genera solidaridad personal, la necesidad de ayudar y preocuparse porque el otro pueda estar bien.

El profesor y psicólogo Howard Gardner (1995) considera la empatía una forma de inteligencia emocional: le da el nombre de inteligencia interpersonal, ya que a través de ella se da la interacción social de forma efectiva y armoniosa, con 
respeto y cooperación para progresar no solo desde lo individual sino en relación con los otros, y no contra o por encima de los demás.

Esta pandemia produce una necesidad urgente de interacción social afectiva y armoniosa entre todos los individuos de la comunidad, así como colectivo se podrá encontrar las rutas comunes de reconstrucción socioemocional, económica y política que serán necesarias para mitigar los efectos propios de las pandemias, esto con el objetivo de que las consecuencias no sean más traumáticas para la esfera civil.

Edith Stein (1916), filósofa polaca que vivió de primera mano como enfermera durante la Primera Guerra Mundial el significado del dolor, el sufrimiento y la muerte, escribe su tesis doctoral en 1916 tomando como referencia de sus propias vivencias el problema de la empatía, que describe como:

[...] por la empatía puedo vivir los valores y descubrir los estratos correspondientes a mi persona, que no han tenido todavía la ocasión de ser desvelados por lo que he experimentado de forma original. Quien no haya visto el peligro de encerrarse en sí mismo, puede mediante la situación del otro por la empatía, darse cuenta de que él mismo es cobarde o valiente. Sin embargo, esto que contradice mi propia estructura de las experiencias, no lo puedo "llenar", pero puedo representármelo de forma vacía, abstracta. (p. 14l)

Sentirse empático de frente a un panorama tan inquietante y desconocido no es fácil, esta pandemia puede tener dos efectos dependiendo de los mensajes que cada país dé a sus ciudadanos y las decisiones de los medios de comunicación que manejan un poder importante de llegar a tantas personas. Por una parte, las personas pueden sentir la necesidad de ser solidarios y pensar en qué vive y siente el otro para ayudarle a que su pena, angustia y dolor sean llevaderos o, por el contrario, sentir la necesidad de estar solo, preocuparse por su entorno más cercano y que cada uno se defienda como pueda, lo que sería una actitud egoísta, pero muy común con este tipo de enfermedades.

En la medida en que los grupos identifican las causas del trauma y asumen su propia responsabilidad moral, los miembros de las colectividades definen sus relaciones de solidaridad para que les permitan, e incluso obliguen, a compartir el sufrimiento de otros. 
¿Es el sufrimiento de los otros también el nuestro? Al pensar que así podría ser, las sociedades amplían el círculo del "nosotros". Cuando se expande este círculo se pueden lograr reparaciones extraordinarias en las redes institucionales y legales de la sociedad (Alexander, 2016, p. 193).

Hoy no se puede desconocer la importancia social de la construcción colectiva del trauma sobre eventos de alto impacto para la comunidad, los testimonios que deja la pandemia del COVID-19 referenciados al sufrimiento, dolor, angustia, desesperanza, pobreza y muerte son una evidencia del arduo trabajo conjunto desde el "nosotros" que debe realizar la comunidad para superar esta adversidad común.

El papa Francisco, en entrevista con el vaticanista Doménico Agasso, del diario La Stampa habla sobre los efectos de la pandemia:

Aquí se llora y se sufre, todos. Solo podemos salir de esta situación juntos, como humanidad entera. Por lo tanto, debemos mirar al otro con un espíritu de solidaridad. Este momento debe ser vivido "con penitencia, compasión y esperanza". Con humildad, porque muchas veces olvidamos que en la vida hay "zonas oscuras", momentos sombríos. Creemos que solo pueden ocurrirle a alguien más. En cambio, este tiempo es oscuro para todos, nadie está excluido. Está marcado por el dolor y las sombras que han entrado en nuestra casa. Es una situación diferente a las que hemos vivido. También porque nadie puede permitirse el lujo de estar tranquilo, todos comparten estos días difíciles. (Papa Francisco, 20 de marzo de 2020)

La reflexión del papa Francisco invita a la solidaridad frente a un evento desafortunado de salud pública para la humanidad. La pandemia del coronavirus es un sufrimiento común para todos que debe dar sentido de responsabilidad ética y moral frente a quienes más lo necesitan, no se puede abandonar a los que están solos y mueren sin el consuelo de sus familiares. El papa habla de la necesidad de tener una mano para sostener tu mano, de un gesto final de acompañamiento. Ya no habrá "el otro" sino que será el "nosotros".

Hay sociedades en las que la solidaridad personal y la compasión funcionan mejor que en otras, porque están arraigadas fuertemente dentro de la cultura, como es el caso de los países escandinavos. Su modelo de esfera civil privilegia altamen- 
te el bienestar social y es fundamental que la esfera civil en conjunto esté bien y se sienta feliz. Como son países con un bajo índice de pobreza y de catástrofes, cuando se presenta un evento desafortunado la sociedad en conjunto se une para solucionarlo. Países como Myanmar, Estados Unidos y Australia, que han sufrido varias catástrofes naturales, han fortalecido la solidaridad personal y comunitaria, la empatía y la compasión.

Por el contrario, en los países de la UE y de América Latina, en general, no predomina la solidaridad personal y la empatía frente a eventos de una magnitud catastrófica como la del COVID-19; la investigación permitió reconocer que en la mayoría de estos países hay un rasgo cultural determinado por el egoísmo, son pocos los que sienten que deben ayudar al otro, si no tienen un vínculo directo.

Así, la falta de solidaridad personal y compasión hacia los otros quedó reflejada en Italia el día antes de decretar la cuarentena obligatoria nacional, un grupo de personas inconscientes e irresponsables por el temor de quedar atrapadas en las declaradas zonas rojas del norte, donde se ubicó el epicentro de la pandemia, decidieron escapar en la noche, en trenes, autos y autobuses de Lombardía hacia el sur de Italia, donde el virus todavía no había llegado a muchas regiones.

A partir de la persona se construye el progreso y desarrollo de la sociedad, sin embargo, en vista de una población numerosa que se encuentra afectada por la pandemia ise puede llegar a consolidar una esfera civil sana y próspera? Las medidas de bloqueo en Italia han permitido efectivamente el control de la infección por COVID-19 en el territorio nacional, incluso en un contexto de transmisión persistente generalizada del virus con una incidencia muy diferente en las 21 regiones, según la información obtenida de la Presidenza del Governo di Consiglio dei Ministri (2020).

Ahora, hay que esperar si las nuevas medidas de reapertura funcionan y los ciudadanos tienen la consciencia social de los cuidados personales y colectivos que se deben tener para evitar rebrotes de la pandemia. 


\section{Felicidad y resiliencia}

De modo que el objetivo común frente a la situación actual se debe enfocar en superar el trauma sociocultural que dejará la pandemia y así entre todos, de forma solidaria, encontrar un estado de bienestar sostenible que lleve de forma real y posible a sentir que la felicidad es posible.

Según el Diccionario de la lengua española (2020), felicidad es un "estado de grata satisfacción espiritual y física". Huxley (1932), en su obra Un mundo feliz da una visión sorprendente de lo que hoy día es la humanidad y el significado de ser feliz, describe cómo los dioses del consumo y la comodidad se han apoderado del sentido de la existencia y los valores humanos de solidaridad y comunidad se han perdido.

Huxley describió visionariamente hace más de ochenta años el mundo que se ha venido construyendo sobre las bases del materialismo y el consumismo, la dictadura universal con apariencia de democracia y la soledad como eje fundamental para estandarizar a la humanidad y facilitar el trabajo a los dirigentes.

Es así como la esfera civil en conjunto debe hacer una reflexión desde adentro y darse cuenta de que la felicidad no puede ser construida sobre la base de valores efímeros y vanos como son los incentivados por las sociedades de consumo, en los que prevalece la necesidad de materializar vivencias y comodidades sin importar cómo pueden afectar a otros. El COVID-19 exige una toma real de consciencia frente a esta amenaza y no se puede seguir viviendo como si la felicidad se hallara en el tener y no el ser.

A continuación, Boris Cyrulnik, psiquiatra francés, padre de la resiliencia, en entrevista con la psicóloga Edith Sánchez el 5 de junio de 2020, manifestó que "la época actual puede ser el preámbulo de una revolución de costumbres y valores”.

Los acontecimientos de 2020 han llevado a la humanidad a que encare directamente la idea de la muerte y a que experimente en su sentido más genuino. Todo esto supone una alteración radical de lo que se llama "normalidad" y pese a que se busca que todo vuelva a la normalidad cuanto antes, lo sucedido dejará huellas que no se van a borrar. 
Felicidad, empatía y solidaridad personal frente al trauma sociocultural de la pandemia en Italia

Pero después de cada crisis hay cambios culturales. Luego, vistos en perspectiva, los consideramos inevitables, aunque ahora lo que nos llega es confusión y desconcierto (Cyrulnik, 5 de junio de 2020).

Cyrulnik (2020) manifiesta en la entrevista que la modernidad ha hecho muy vulnerable a la humanidad. Sin embargo, se piensa lo contrario, la sensación que prevalece en los últimos tiempos es opuesta, en el sentido de que la evolución de la ciencia y la tecnología y los sistemas sociales hicieron creer a la humanidad invulnerable. No se puede negar que la modernidad ha mejorado las condiciones materiales y la calidad de vida, pero a su vez ha generado situaciones que la humanidad no está en condiciones de controlar.

En otro aparte de la entrevista el autor afirma:

Si una catástrofe provoca un caudal elevado de desgracia, es más probable que tras ella se produzca una gran revolución. A diferencia de otros analistas. Boris Cyrulnik piensa que las restricciones impuestas en varios países del mundo, durante los últimos meses, son un código prohibitivo que tranquiliza. Se trata de un código de supervivencia: debes hacer esto, o no debes hacer aquello para tener mayores probabilidades de sobrevivir. Aunque se trata de restricciones, estas reducen la ansiedad que provoca el peligro. (Cyrulnik, 5 de junio de 2020)

Cyrulnik concluye que lo desconocido y peligroso provoca en el ser humano una especie de agonía emocional. Por eso después de catástrofes como la del COVID-19 se deben hacer procesos de evaluación para establecer las causas y así impedir que estos eventos traumáticos vuelvan a ocurrir y para eso son necesarios los cambios más radicales en la medida en que las situaciones sean más devastadoras y lo que vive la humanidad lleve a transformaciones fundamentales.

La resiliencia como potencia humana para enfrentar la adversidad se dará poco a poco para quienes tomen la decisión personal de luchar contra el fantasma del coronavirus y decidan superarlo de forma positiva para reencontrarse con la felicidad. La humanidad está viviendo una catástrofe incomprensible que deja muchos interrogantes y pocas respuestas asertivas hasta ahora, el coronavirus es una enfermedad desconocida que genera muchas incertidumbres y enfrentarla de forma resiliente y positiva tomará su tiempo. 
La investigación cumplió con el objetivo de identificar los elementos comunes experienciales que acerquen a la comunidad entre sí de forma empática para reconstruirse colectivamente y se propone el diseño de talleres y conferencias resilientes virtuales, y cuando sea posible, presenciales, para desarrollar las capacidades de un trabajo colaborativo con miras a compartir y mejorar las experiencias y prácticas entre los diferentes integrantes de la esfera civil. En la bibliografía se anexan referencias para profundizar sobre este tema con autores como Cyrulnik (2008), Manciux (2010) y Evans y Reid (2016).

Es primordial tener cuidado con la infodemia (exceso de información sin control) que está afectando a tantos ciudadanos mentalmente a nivel global por la saturación de noticias sobre el coronavirus, en Italia uno de los países más afectados, el daño emocional ha sido grande para muchas personas, ya que desde el comienzo de la cuarentena en febrero de 2020 se dedicaron a ver y buscar noticias sobre el COVID-19 con la necesidad de saberlo todo, sin embargo, no siempre las noticias de algunos medios son objetivas y veraces.

Como lo afirma el sociólogo norteamericano RifKin (2000), en la nueva era el mundo entraría en una etapa de sobresaturación informativa, donde aparecerían muchas verdades imposibles de discernir. El manejo de los datos informativos tiene un riesgo incalculable, ya que pueden ser utilizados como un virus para satisfacer los intereses de ciertos grupos de poder.

Es así como dos décadas después, Rifkin estaba en lo cierto y su teoría sobrepasó la realidad. La vivencia actual de la pandemia COVID-19 deja como evidencia que el inadecuado manejo de la información puede ser más peligroso que el virus en sí.

\section{Análisis de resultados}

Culturalmente, a países como Italia y España les ha sido más difícil manejar la pandemia por su rutina social, que es coloquial y fraternal, por el contrario, a países como Alemania, Holanda y Polonia, donde sus interacciones cotidianas son más frías y distantes, esto les ha permitido obtener mejores resultados frente al manejo del COVID-19. Además, son países culturalmente más disciplinados y 
estrictos que Italia y España frente a las medidas restrictivas (Wanda Punzi, 13 de abril de 2020, comunicación personal).

Como lo afirma Lauro Rinaldi, guía turístico de 55 años en la costa amalfitana:

Soy un padre de familia que velo junto con mi esposa por el bienestar nuestro y de dos hijos que tenemos terminando estudios universitarios. Esta pandemia no ha sido fácil, durante meses el trabajo paró y ahora nada es lo mismo, después de lo que se vivió en el norte, da mucho temor que en cualquier momento llegue el contagio y uno no se dé cuenta y luego se agrave y muera. (L. Rinaldi, comunicación personal, 28 de mayo de 2020)

En consecuencia, en el día a día, la mayoría de los ciudadanos no se sienten tranquilos y tienen un gran temor de actuar como si la enfermedad ya fuera cuestión del pasado. Los científicos que asesoran al Gobierno italiano previeron que el virus regresaría en el otoño, la afirmación la hacen sobre la conclusión de que Italia está recibiendo extranjeros en el verano, la diferencia radica en que ahora el COVID-19 tendría características diferentes a las del círculo de los primeros meses del año y el clima de otoño y de invierno son un catalizador para este tipo de virus.

Sin dudar, la OMs (2020) afirmó en un informe de prensa que ningún país puede bajar la guardia y pensar que el virus ya está controlado, la circulación masiva de personas en las calles y lugares de concentración como iglesias, mercados, colegios, universidades, transporte público, cinemas, hará que el virus recircule de nuevo. Para controlarlo de forma segura serían necesarias cuarentenas estrictas prolongadas, cerrar las fronteras por tiempo indefinido, lo cual no es posible por los efectos emocionales y económicos.

Es así que hoy en día Italia registra una evolución positiva del control del virus en todo el país; el Departamento de Protección Civil, entidad pública encargada del control sanitario de la pandemia, informó que para el 15 de julio de 2020 la tasa de contagios y muertes tendía a la baja, lo que hacía a la pandemia estacionaria.

En todo caso, el virus siguió su expansión a otros países de Europa. En un esfuerzo de reivindicar su posición, la UE ofreció algunos apoyos económicos y sociales 
Figura 1. Evolución del virus desde el primer caso registrado hasta 2020

\begin{tabular}{|c|c|c|}
\hline Fecha & Cantidad de contagios & Fallecimientos \\
\hline 10 de febrero de 2020 & 2 & 0 \\
\hline 28 de febrero de 2020 & 650 & 17 \\
\hline 10 de marzo de 2020 & 15.000 & 1.016 \\
\hline 28 de marzo de 2020 & 74.000 & 7.500 \\
\hline 10 de abril de 2020 & 143.626 & 18.200 \\
\hline 25 de abril de 2020 & 195.351 & 26.384 \\
\hline 10 de mayo de 2020 & 219.070 & 30.560 \\
\hline 25 de mayo de 2020 & 230.158 & 32.877 \\
\hline 16 de junio de 2020 & 237.290 & 34.733 \\
\hline 20 de julio de 2020 & 244.624 & 35.058 \\
\hline
\end{tabular}

Fuente: elaborada por Sandra Ligia Ramírez Orozco con la información del Departamento de Protección Civil en Roma (2020)

a países como Italia, pero en definitiva los más de 60 millones de italianos, según datos de Anagrafe, saben que la reconstrucción del trauma sociocultural que deja el COVID-19 depende de la esfera civil en conjunto.

En un informe de prensa (junio de 2020) la OMS sugiere a la comunidad internacional - ante la imposibilidad de una vacuna que cumpla las condiciones de sanidad a corto plazo - unirse para luchar contra este virus invisible de forma conjunta, solidaria y armónica, pues el objetivo es educar a los ciudadanos de forma responsable para que aprendan a convivir con el enemigo invisible que representa esta enfermedad.

No obstante, el domingo 19 de julio de 2020 Italia logró el récord positivo de solo 3 fallecidos y 219 nuevos contagiados de coronavirus en 24 horas. Las alarmas están encendidas porque con la llegada del verano el comportamiento social, en particular de los jóvenes, es cada día más tranquilo y se están dejando de seguir las medidas preventivas para evitar rebrotes.

El 17 de julio de 2020, Tedros Adhanom, hizo un llamado urgente a la comunidad internacional para unirse solidariamente y combatir el virus, que está colapsan- 
do a nivel global los sistemas de salud y las economías, con un saldo de vidas perdidas de 606.173 hasta julio de 2020. Es necesaria la solidaridad global para encontrar una vacuna que controle esta enfermedad.

El profesor Massimo Andreoli, director de Enfermedades Infecciosas en la Universidad de Tor Vergata de Roma, en conversación para el diario El Clarín de Argentina, afirma:

Las internaciones prosiguen y hay camas de terapia intensiva de nuevo ocupadas. El virus es el mismo, lo que pasa es que aprendimos mucho a curar a los enfermos. Además, los internados ahora son más jóvenes porque violan las medidas de seguridad. Tenemos que resistir seis meses más, el peligro de una recaída es enorme. La estrategia italiana es seguir profundizando la lucha contra los nuevos brotes que se presentan todos los días y aumentar los controles de identificación de nuevos contagiados y de aislamiento rígido. (Andreoli, 20 de julio de 2020)

Existe una preocupación entre los científicos y el Gobierno italiano de que, en agosto de 2020, cuando aumente la afluencia turística por el verano, los contagios se incrementaran. El baile y los centros de reunión para consumir licor son ahora un desafío para el Gobierno, ya que los jóvenes quieren juntarse y bailar de noche, aunque esté prohibido.

Un impacto tan fuerte como el generado por el coronavirus a nivel global solo es comparable al de una guerra en la que se contraponen y contrastan los sentimientos, la toma de consciencia frente al peligro real de perder la vida y el deseo de sobrevivir.

Anallisa Albano, profesora de primaria de 45 años, manifiesta:

Soy una mujer soltera, no tengo hijos, adoro a los niños. Ha sido muy difícil no poder tener contacto personal todos estos meses, estoy acostumbrada a ser muy cariñosa con ellos y a compartir sus vivencias escolares. Me siento sola, como abandonada, las clases virtuales no son lo mismo y menos con los pequeños, ellos se cansan rápido y quieren hacer otras cosas. A veces me pregunto, así como las guerras han afectado el comportamiento humano, la forma de ver y sentir la vida, cómo afectará esta pandemia a los niños y jóvenes de hoy. (Comunicación personal, 28 de mayo de 2020) 
Sin duda, lo que se conocía hasta hoy como la forma cotidiana de vivir, estudiar, trabajar, divertirse, relacionarse con otros, cambió de forma abrupta y parece que por un largo tiempo. Entonces muchos ciudadanos se preguntan "iahora cómo será mi vida?", muchas personas no conciben su existencia sin relacionarse de forma presencial con otras personas y compartir constantemente diferentes espacios sociales.

Rogelio Morelli, de 24 años, estudiante universitario de comunicación, señaló:

Para mí esta experiencia de la pandemia es muy difícil, porque la vida cambió en todos los sentidos. No soy feliz, porque no puedo salir con tranquilidad a compartir con los amigos, dejé de ver a la novia durante meses, entender que se debe ser responsables con nuestra familia para no contagiar a nadie en caso de ser asintomático, salir y ver tu ciudad desierta, tal vez como lo vivieron nuestros antepasados en las guerras, sentir que no eres libre y pensar que el futuro es muy incierto, ni los expertos saben qué puede pasar. (Comunicación personal, 11 de abril de 2020)

Los jóvenes se sienten confundidos y con pocas posibilidades de construir una vida feliz, se enfrentan a una serie de incertidumbres porque no saben qué les depara el futuro cercano, qué posibilidades de estudio y trabajo reales tienen, el temor de conformar una familia y tener hijos en un mundo tan convulsionado. El encierro forzoso con esas ansias y el deseo de la juventud de salir a vivir y explorar nuevas experiencias y aventuras como sinónimo de juventud, ¿dónde quedan? Ahora la aventura se puede tomar como sinónimo de irresponsabilidad.

De acuerdo con los resultados de esta investigación surge un interrogante: ise podría argumentar que la humanidad es responsable de la aparición del COVID-19? Por la forma en que se abusa del medio ambiente, el cambio climático ha sido una clara consecuencia de esto, la relación que se tiene con los otros seres vivos de la naturaleza como la caza de animales silvestres no aptos para el consumo humano. Hasta la fecha no hay una respuesta concreta sobre la responsabilidad directa o indirecta de esta enfermedad. Lo cierto es que mientras se establece el origen del virus, es necesario enfrentarlo y aprender las lecciones y experiencias 
vividas para poder controlar de forma efectiva y a tiempo próximas pandemias en el futuro.

Una invasión abrupta e inesperada como ha sido este virus en Italia a partir del 20 de febrero de 2020 y que hoy en día, según informe del Departamento de Protección Civil (2020), con más de 244.624 contagiados y más de 35.058 muertos, obliga a la esfera civil a cambiar sus dinámicas relacionales y la manera de llevar la vida en el día a día.

Al contrastar la situación de Italia con la de Colombia frente a la pandemia, se puede decir que Italia es un país del primer mundo con un sistema de salud público robusto, un sistema de seguridad social que protege a toda la población, el Estado está en capacidad de brindar un subsidio de renta básica a los más vulnerables para que puedan sobrevivir dignamente a la falta de alimentación, vivienda y empleo. Es miembro de la UE, lo que le da la posibilidad de acceder a varios beneficios comunitarios.

Colombia, por su parte, es un país sin un sistema de salud robusto, un sistema de salud que no es público, una corrupción desmedida en todos los escenarios de la esfera civil que hace preocupantes las consecuencias socioemocionales y económicas, por la desigualdad y la falta de oportunidades que son evidentes para llevar una buena calidad de vida y bienestar después de la pandemia.

\section{Conclusiones}

Luego de vivir de cerca lo que ha significado para Italia el trauma sociocultural de la pandemia en 2020, con estelas de angustia, temor, desesperanza, desempleo y pobreza, se puede concluir que una adversidad como esta marca a la esfera civil en todos sus ámbitos, lo que hace fundamental una reflexión desde el "yo" para acercarse al dolor del otro y juntos entender desde el "nosotros" lo que ha significado este dolor y sufrimiento a nivel individual y social.

En consecuencia, la experiencia vivencial, la comparación de los testimonios, la información documental y oficial del Estado italiano, hacen que la investigación 
continúe en proceso, ya que el fenómeno social objeto de estudio continúa vigente a nivel y no ha finalizado.

Como resultado de esta revisión quedan muchos interrogantes que exigen continuar trabajando en el tema del trauma sociocultural que está causando el COVID-19 en la comunidad internacional. Sería interesante realizar una investigación en el futuro de estudio comparativo entre Colombia e Italia sobre las consecuencias socioemocionales pospandemia para armonizar la esfera civil.

Por otra parte, la infodemia de las noticias frente a estos temas de sensibilidad social abunda y se puede generar un pánico colectivo más grave que la propia pandemia. Sirve de ejemplo, el caso de finales de abril en el sur de Italia, Nápoles, en la región de Campania, en una situación aislada unos jóvenes robaron a unos ciudadanos las bolsas de mercado porque no tenían para comer. El impacto que generó la noticia fue tan fuerte que hubo personas que sintieron un gran temor de salir a comprar los alimentos y ser atacados.

Por ello, se requiere tener cuidado en la época de la pandemia con la manera como se da la información a los ciudadanos para no generar pánico y angustia colectiva. No todos los ciudadanos por diferentes variables como edad, nivel de educación, cultura, religión, pueden comprender ciertos comportamientos atípicos causados por las circunstancias poco comunes que puede generar una enfermedad como el COVID-19.

En conclusión, la investigación con relación al trauma sociocultural que ha dejado la pandemia sobre la persona y la convivencia de la comunidad establece necesidades reales para la sociedad contemporánea de reflexionar en torno al yo. Así como la responsabilidad moral de empatía y solidaridad frente a los otros que permita brindar un espacio de felicidad y armonía después de la pandemia.

Para finalizar, es preciso resaltar que por ahora Italia siente que va por buen camino, desde finales de mayo de 2020 se considera que la pandemia es estacionaria, que difícilmente regresará, que los ciudadanos cada día son más conscientes de la pesadilla que se vivió los primeros meses del año y que nadie quiere repetir. 
Felicidad, empatía y solidaridad personal frente al trauma sociocultural de la pandemia en Italia

\section{Aunque, con un enemigo invisible como el coronavirus, no se puede predecir qué sucederá.}

\section{Referencias}

Alexander, J. (2006). The Civil Sphere. Oxford: Oxford University Press.

Alexander, J. (2016). Trauma cultural, moralidad y solidaridad. La construcción social del holocausto y otros asesinatos en masa. Revista Mexicana de Ciencias Politicas y Sociales, Nueva Época, 61 (228), 191-210.

Ancestros Italianos. (2020). Servicios demográficos. Ancestros Italianos. http://www.ancestrositalianos. com/archivos/servicios-demograficos.html

Andreali, M. (2020). A la espera de la vacuna Italia se prepara para "resistir seis meses" luchando contra el rebrote del coronavirus. El Clarín, 20 de julio. https:/www.clarin.com/mundo/italia-prepararesistir-meses-luchando-rebrote-coronavirus_0_eabZBaPu8.html

Cyrulnik, B. (2020, 5 de junio). La época actual puede ser el preámbulo de una revolución de costumbres y valores. La Mente es Maravillosa. https://lamenteesmaravillosa.com/ boris-cyrulnik-la-epoca-actual-puede-ser-el-preambulo-de-una-revolucion/

Dipartamento de Protezione Civile. (2020). Rapporti emergenza coronavirus. Protezione Civile. www. protezionecivile.gov.it

Gardner, H. (1995). Las inteligencias múltiples: la teoría en la práctica. Barcelona: Paidós.

Huxley, A. (2014). Un mundo feliz. Ciudad de México: Ediciones del Sindicato Nacional de Trabajadores del Infonavi.

Istituto di Ricerche Farmacologiche. (2020). Rapporti pandemia, notizie in evidenza en Istituto di Ricerche Farmacologiche Mario Negri. www.marionegri.it

Organización Mundial de la Salud (OMS). (2020). Informes oficiales del director Tedros Adhanom. https://www.who.int/es

Organización Mundial de la Salud (OMS). (2010). ¿Qué es una pandemia? https://www.who.int/csr/ disease/swineflu/frequently_asked_questions/pandemic/es/

Papa Francisco. (2020, 20 de marzo). Pope Francis: "Don't be afraid”. Diario La Stampa. https://www. lastampa.it/esteri/la-stampa-in-english/2020/03/20/news/pope-francis-don-t-be-afraid-1.38613776

Presidenza del Consiglio. (2020). Infome oficial en Governo italiano, presidenza del consiglio. www. governo.it

Real Academia Española. (2014). Diccionario de la lengua española. https://dle.rae.es/peste

Real Academia Española. (2020). Diccionario de la lengua española. https://dle.rae.es/pandemia?m=form

Rifkin, J. (2000). La era del acceso: la revolución de la nueva economía. Barcelona: Paidós. 
Stein, E. (2014). Il problema dell'empatia [tesis doctoral ]. Constantini, E. y Schulze, E. (trad.). Roma: Edizione Studium.

Taylor, S. J. y Bogdan, R. (1989). Introducción a los métodos cualitativos de investigación. La búsqueda de significados. Barcelona: Paidós Ibérica.

Tomasi, S. N. (2020). Historia de las pandemias mundiales y la economía. https://magatem.com.ar/historia-de-las-pandemias-mundiales-y-la-economia.pdf

\section{Bibliografía}

Alexander, J. C. (2012). Trauma: A social theory. Cambridge: Polity Press.

Alexander, J. C., Eyerman, R., Giesen, B., Smelser N. y Sztompka, P. (2004). Trauma cultural e identidad colectiva. Prensa de la Universidad de California.

Álvarez-Gayou, J. (2003). Cómo hacer investigación cualitativa: fundamentos y metodología. Ciudad de México: Paidós.

Cuervo, M. (1993). La calidad de vida: juicios de satisfacción y felicidad como indicadores actitudinales de bienestar. Revista de Psicología Social, 1 (8), 101-110.

Cyrulnik, B. (2008). Autobiografía de un espantapájaros: testimonios de resiliencia: el retorno a la vida. Barcelona: Gedisa.

Evans, B. y Reid, J. (2016). Una vida en resiliencia: el arte de vivir en peligro. Ciudad de México: Fondo de Cultura Económica.

Eyerman, R., Alexander, J. y Butler, E. (2016). Narrating trauma: On the impact off collective suffering. En Yale Cultural Sociology Series (pp. 191-212). Nueva York: Routledge.

Galeano M., M. E. (2004). Diseño de proyectos en la investigación cualitativa. Medellín: Universidad EAFIT.

Grotberg, E. (2006). La resiliencia en el mundo de hoy. Barcelona: Gedisa.

Jedlowski, P. (2000). La sociología y la memoria colectiva. En A. Rosa, G. Bellelli y D. Bakhurst (eds.), Memoria colectiva e identidad nacional (pp. 123-134). Madrid: Biblioteca Nueva.

Kristeva, J. (1991). Extranjeros para nosotros mismos. X. Gispert (trad.). Barcelona: Plaza \& Janés.

Manciaux, M. (2010). La resiliencia: resistir y rehacerse. Barcelona: Gedisa.

Mayntz, R., Holm, K. y Hübner, P. (1985). Introducción a los métodos de la sociología empírica. Madrid: Alianza.

Mercado-Martínez, F. J. (2002). Investigación cualitativa en América Latina: perspectivas críticas en salud. International Journal of Qualitative Methods, 1 (1), 1-27.

Montuschi, L. (2017). Crecimiento económico, progreso social y felicidad. Serie Documentos de Trabajo.

Nussbaum, M. (2017). Emociones políticas. Bogotá: Planeta.

Páez, D., Fernández, I. y Beristain, C. M. (2001). Catástrofes, traumas y conductas colectivas: procesos y efectos culturales. Barcelona: Universidad del País Vasco, Icaria. 


\section{$96-\mathrm{M} A \mathrm{EST}$ T R S}

Felicidad, empatía y solidaridad personal frente al trauma sociocultural de la pandemia en Italia

Papa Francisco. (2013). Carta encíclica lumen fidei, Santiago de Chile: Edición Digital Decamini Editores.

Sánchez, E. yDelgado, A. (2002). La resiliencia. Responsabilidad del sujeto y esperanza social. Cali CEIC-Rafue, Casa Editorial.

Schwalb, V. (2012). Todos somos resilientes. Buenos Aires: Paidós. 


\section{4 \\ Persona y felicidad en el Magisterio de Juan XXIII (1958-1963)}

FRANCESCO FERRARI*

Vino al mundo un hombre enviado por Dios, cuyo nombre era Juan. Este vino como testigo para testificar de la Luz, a fin de que todos creyeran por medio de él.

$(J n, I, 6-7)^{1}$

\section{Resumen}

Por medio de una metodología documental que analiza las fuentes primarias del magisterio pontificio como los textos publicados en las Acta Apostolicae Sedis, el presente trabajo busca profundizar en los conceptos de persona y felicidad en la reflexión propuesta por el Papa Juan XXIII (1958-1963).

En el pensamiento del Pontífice, el concepto de persona puede agruparse en tres grandes núcleos temáticos: la dignidad de la persona humana; los "lugares" de la formación y maduración, y las amenazas contemporáneas a la persona. La reflexión sobre la felicidad tiene un papel importante en el pensamiento de este Papa que subrayó, sobre todo, el rol de la Iglesia en el apoyo y acompañamiento

\footnotetext{
* Historiador de la Universidad de Turín, Italia y Ph. D. en Historia del Cristianismo Contemporáneo de la Universidad de Boloña, Italia. Vinculado al Departamento de Humanidades como docente de la asignatura Cultura Católica; líder del semillero Educación, Mujer y Familia y líder de la línea de investigación Educación, Ética y Política, adscrito al grupo Philosophia Personae de la Universidad Católica de Colombia. Además, docente en la Maestría en Ciencia Política de doble titulación con la Universidad de Salerno y la Universidad Católica de Colombia. fferrari@ucatolica.edu.co https://orcid.org/0000-0002-3303-0586

1 Con esta cita evangélica, el cardenal León Joseph Suenens, primado de Bélgica de 1961 a 1979 y figura clave del Concilio Vaticano II, abría un hermoso artículo escrito poco después de la muerte de Juan XXIII en el que afirmaba: "es cierto que, en su sentido literal, estas palabras hacen referencia a Juan el Bautista, el precursor del Señor. Sin embargo, ellas vienen irresistiblemente a la mente de cualquiera que piense al Papa que acaba de dejarnos: Juan XXIII de santa y venerada memoria" (Suenens, 1964, p. 429).
} 
de la natural predisposición humana a la búsqueda de la felicidad y la interconexión entre la felicidad terrenal y la celeste.

Se describe así un pensamiento que retoma el magisterio precedente, en particular, los de León XIII y Pío XII, con aspectos originales como el apoyo del Papa a las organizaciones internacionales que comparten con la Iglesia la defensa de la dignidad humana, la migración como derecho derivado de la dignidad humana y la igualdad en dignidad entre hombres y mujeres.

Finalmente, la reflexión sobre persona y felicidad de Angelo Giuseppe Roncalli confirma la capacidad del "Papa bueno" de tener juntas la tradición con la aceptación de los "signos de los tiempos", enseñando a la Iglesia una vía exigente, pero indispensable para seguir cumpliendo su misión en este comienzo de tercer milenio y dejando un importante legado recogido y ampliado en los últimos años por Francisco.

Palabras clave: Juan XXIII, magisterio pontificio, dignidad humana, progreso industrial, felicidad celeste.

\section{Introducción}

Las palabras persona y felicidad forman parte del patrimonio del pensamiento cristiano y, en particular, del magisterio pontificio que ha reflexionado sobre estos dos conceptos en múltiples direcciones a lo largo de su historia.

El primer término, persona, se encuentra en el centro del misterio cristiano de la encarnación y "es el fundamento [...] de la enseñanza social de la Iglesia" (Sigmund, 2019, p. 4). Es imposible sintetizar aquí el articulado debate histórico y teológico alrededor de este tema; sin embargo, parece oportuno resaltar un aspecto de esta reflexión: la dignidad de la persona derivada de la creación del ser humano a imagen y semejanza de Dios, siendo uno de los pilares de la doctrina social de la Iglesia ${ }^{2}$. Esta perspectiva ha sido analizada por muchas encíclicas

2 "La dignidad de la persona humana está enraizada en su creación a imagen y semejanza de Dios (artículo primero); se realiza en su vocación a la bienaventuranza divina (artículo segundo). Corresponde al ser humano llegar libremente a esta realización (artículo tercero). Por sus actos deliberados (artículo cuarto), la persona 
papales como, por ejemplo, la Humanae vitae (25 de julio de 1968) de Pablo VI; las Sollicitudo Rei socialis (30 de diciembre de 1987) y Evangelium Vitae (25 de marzo de 1995) de Juan Pablo II.

El concepto de felicidad se encuentra ya en el Nuevo Testamento, como se puede notar en el segundo capítulo del Evangelio de Lucas, cuando el nacimiento de Jesús es proclamado como la gozosa noticia que llena de alegría al mundo. Este tema se encuentra también en el Evangelio de Mateo - en particular, en el sermón de la montaña ${ }^{3}$ (Mt v, l; VII, 28) - , y ha sido el centro de numerosas investigaciones de historia y sociología de la religión (Hout y Greeley, 1972; Larrimore, 2010).

Ya san Agustín (390) decía que este discurso, y en particular las bienaventuranzas (Mt, v, 3-12), constituía "la forma definitiva de la vida cristiana" (p. 5). El Papa Francisco (2018), escribe que, representa "el carnet de identidad de los cristianos" (n.․ 63). La felicidad es el centro del magisterio de Jorge Mario Bergoglio - como se observa la exhortación apostólica Evangelii gaudium, del 24 de noviembre de 2013 - el cual le dio y sigue dándole una relevancia particular y, diría, única. Vale resaltar que el concepto de felicidad también se encuentra presente en los pontificados precedentes, como demuestra la exhortación apostólica de Pablo VI, Gaudete in Domino de 9 de mayo de 1975.

La investigación que se presenta busca analizar la línea de reflexión magisterial alrededor de los conceptos de persona y felicidad en el pontificado de Juan XXIII (28 de octubre de 1958-3 de junio de 1963) ${ }^{4}$, que, como escribía el cardenal Sue-

\footnotetext{
humana se conforma, o no se conforma, al bien prometido por Dios y atestiguado por la conciencia moral (artículo quinto). Los seres humanos se edifican a sí mismos y crecen desde el interior: hacen de toda su vida sensible y espiritual un material de su crecimiento (artículo sexto). Con la ayuda de la gracia crecen en la virtud (artículo séptimo), evitan el pecado y, si lo han cometido recurren como el hijo pródigo (cf. Lc 15, 11-31) a la misericordia de nuestro Padre del cielo (artículo octavo). Así acceden a la perfección de la caridad" (Catecismo de la Iglesia católica, 1992, n.․1700). El pensamiento católico sobre la dignidad humana está recogido en Castañeda (2002).

3 El sermón de la montaña ha sido comentado por Juan Pablo II, Homilía en la Santa Misa Para los jóvenes en Korazim (Israel) de 24 de marzo de 2000, Benedicto XVI, Ángelus de 30 de enero de 2011 y Francisco, Exhortación apostólica Gaudete et exsultate, cap. III.
}

4 Este pontificado ha sido uno de los más importantes del siglo Xx sea desde el punto de vista de la historia global, mirando a la historia de la Iglesia católica. Papa Roncalli, de hecho, fue protagonista de numerosos acontecimientos históricos entre los cuales el más importante es, seguramente, la crisis de los misiles de Cuba 
nens (1964) “abrió una nueva era para la Iglesia permitiéndole la transición del siglo XX al XXI" (p. 429).

Como se puede ver en la bibliografía anexa, este pontificado ha sido el foco de numerosas investigaciones que se han centrado sobre todo en el papel de Juan XXIII en el desarrollo del Concilio Vaticano II y en las relaciones del Pontífice con los dirigentes políticos italianos, estadounidenses y soviéticos. Desde la perspectiva del análisis del pensamiento de Angelo Giuseppe Roncalli, los historiadores han enfocado su atención en una gran variedad de aspectos ayudados por la valiosa documentación personal presente en los diarios del Papa (Coppa, 2011) y los temas más recurrentes de dichas investigaciones son las reflexiones del Papa sobre la paz y la cuestión social. La presente investigación, por ende, tiene como

(16-28 de octubre de 1962). Como reconocieron las mismas autoridades soviéticas (Redina, 1983, p. 808), el radiomensaje pronunciado por el Papa el 25 de octubre logró disminuir la tensión entre las dos superpotencias y evitar un conflicto catastrófico para todo el planeta. Juan XXIII, además, tuvo que enfrentarse con los cambios sociales impulsados por la rápida industrialización de Estados Unidos y Europa occidental e hizo salir a la Iglesia del clima de dura contraposición entre los bloques característicos de esta fase de la guerra fría. El Papa favoreció, en muchos países como, por ejemplo, Italia, un cambio en el compromiso político de los católicos que se hizo menos cercano al frente anticomunista y más atento a las necesidades de los sectores vulnerables de la población. El Papa dejó una marca profunda en la sociedad de su tiempo, primero por sus capacidades diplomáticas, que fueron reconocidas por la importante revista Time que lo nombró personaje del año 1962, y segundo, por su estilo personal empático, de trato fácil y amigable, como se denota en celebre Discurso de la luna del ll de octubre de 1962. La ternura y amabilidad de Roncalli le permitieron ganar unos conocidos apodos como "el Papa bueno" o "el párroco del mundo".

Desde el punto de vista eclesial, el pontificado de Juan XXIII, nombrado Papa a la avanzada edad de 76 años, tenía que ser de transición después del largo y muy complejo reino de Pío XII (1939-1958). Sin embargo, Angelo Giuseppe Roncalli, ya desde el comienzo de su gobierno hizo entender que quería modificar profundamente el rumbo seguido por la Iglesia hasta la fecha y el 25 de enero de 1959, a menos de tres meses de su elección, puso en marcha el más importante proceso de la historia de la Iglesia del siglo Xx representados por el Concilio Vaticano II. En la mente del Papa, la asamblea conciliar tenía que concluir las labores del Vaticano I, que no pudo terminar debido a la invasión italiana de Roma de 1870, reformar el código de derecho canónico y proveer el catolicismo con herramientas nuevas y más efectivas para acoger y guiar a las sociedades en rápido cambio. El Papa lombardo, además, escribió unas encíclicas fundamentales para el desarrollo de la Doctrina Social de la Iglesia y de la actividad pastoral de los católicos comprometidos. Con la Mater et magistra, publicada el 15 de mayo de 1961, o sea, dos años después de la toma del poder de Fidel Castro en Cuba, amplió la enseñanza social del magisterio, subrayando el valor de la persona y enfrentando los nuevos retos de la segunda posguerra como la crisis de la sociedad campesina, la descolonización y el creciente subdesarrollo de importantes áreas del planeta. Con la Pacem in terris del 11 de abril de 1963, dejó en evidencia el valor de la paz en un mundo funestado por las divisiones como la simbolizada por el muro de Berlín, cuya construcción empezó la noche entre el 12 y el 13 de agosto de 1961. Con este documento el Papa afirmó que la Iglesia no pertenecía a ninguno de los dos frentes, una declaración para nada banal en el marco de la guerra fría. A pesar de que el proceso empezado por el Papa aquel 25 de enero de 1959 no terminó como previó Roncalli y de que en la Iglesia se abrieron profundas divisiones que afectaron mucho el pontificado sucesivo de Pablo VI, nadie puede negar la fundamental relevancia del reino de Juan XXIII, recientemente reconocida también por la Iglesia del Papa Francisco que canonizó al Pontífice lombardo el 27 de abril de 2014. 
objetivo aportar nuevo conocimiento al área de la ciencia histórica contestando a la pregunta: icómo y cuándo Juan XXIII, en los documentos que forman su magisterio, emplea las palabras persona y felicidad?

El estudio que se describirá a continuación se encaja en el contexto específico de la historia del siglo xx y de la historia de la Iglesia. Se realizó utilizando la metodología documental de análisis del magisterio pontificio contemporáneo, ya empleada por Batelli (1993), Bernárdez-Cantón (1964), Blot (2010), Britto (2010), Canepa (1992), Chenaux (2016), Coppa (2003), Daniel (2011), García-Alendete (2018), La Bella (2018), Viotto (1998), y por mí, en dos trabajos precedentes (Ferrari, 2017b; 2018).

Esta metodología prevé la elección de una o más temáticas, como pueden ser, por ejemplo, la relación entre catolicismo y judaísmo o la movilidad humana. Por medio del examen de los documentos que forman parte del magisterio papal (como las cartas encíclicas, las constituciones apostólicas, las alocuciones y otros), se subraya el pensamiento de uno o más pontífices sobre los temas escogidos.

El empleo de dicha metodología tiene el doble propósito de averiguar si los conceptos de persona y felicidad constituyen aspectos relevantes del pensamiento de Juan XXIII y de constituir el comienzo de una investigación más amplia, que abarque, con las mismas premisas y herramientas metodológicas, los pontificados sucesivos, por lo menos hasta el Papa Benedicto XVI.

\section{La centralidad de la persona, sus "lugares" de formación y las amenazas contemporáneas a la dignidad humana}

En la reflexión de Juan XXIII, el uso del concepto de persona puede ser dividido en tres grandes núcleos temáticos: la centralidad y dignidad de la persona; los "lugares" y categorías sociales encargadas de su formación, y las amenazas contemporáneas a la persona.

Retomando el magisterio precedente y en particular el de León XIII (1878-1903), Pío XI (1922-1939) y Pío XII (1939-1958), el Pontífice (1963a) afirmaba que "el cen- 
tro de cada preocupación quiere ser la persona humana creada a imagen y semejanza de Dios y redimida por la preciosísima sangre de Cristo" (p. 9l). De esta creación y redención derivaba que cada hombre tenía, desde su nacimiento y hasta el último instante de su vida ${ }^{5}$, una dignidad inviolable cuyo respeto debía ser el criterio orientador de cualquier actividad humana como la familia, la escuela, la política, la economía, el arte y la prensa (Juan XXIII, 1960a) ${ }^{6}$.

Por medio de esta orientación se podía alcanzar la verdadera paz social anhelada por Dios y por la Iglesia. Según el Papa, si las instituciones y las sociedades tomaran a la persona como criterio de valor, podrían cesar las discordias sociales y construir una sociedad más justa y regida por "la verdad que ilumina todo y asegura armonioso desarrollo a la persona, dignidad a la familia y al trabajo" (Juan XXIII, 1962d, p. 404).

Esta verdad se sustenta en los principios de la Doctrina Social de la Iglesia, que fueron planteados y ampliados por el "Papa bueno" sobre todo en la encíclica Pacem in Terris de 1963. En este documento se reafirmaba que la dignidad humana era inviolable y otorgaba al ser humano derechos que nadie podía quitarle. Entre estos derechos, el Pontífice subrayaba el de ejercer la actividad económica libremente con un salario correcto y el de poseer el fruto de su trabajo.

El derecho a la propiedad privada fue expuesto por el Papa también en la encíclica Mater et magistra de 1961 en la que lo describía como:

[...] medio eficiente para garantizar la dignidad de la persona humana y el ejercicio libre de la propia misión en todos los campos de la actividad económica, y es, finalmente, un elemento de tranquilidad y de consolidación para la vida familiar, con el consiguiente aumento de paz y prosperidad en el Estado. (Juan XXIII, 196la, n. $\left.{ }^{\circ} 112\right)^{7}$

5 En la homilía por la fiesta de la purificación de la Virgen, Juan XXIII (1963b) decía que "cada persona, en cada instante de su vida, también en el momento de máximo sufrimiento, está llamada a cooperar activamente a los diseños de la Providencia" (p. 90).

6 En el mensaje a los fieles en ocasión de la Vigilia de Navidad de 1959, el Papa (1960a) recordaba que: "Si Dios amó al hombre al punto de entregar su hijo único, eso significa que el hombre le pertenece y que se debe absolutamente respetar la persona humana. Por eso la Iglesia enseña que la solución de las cuestiones sociales se realiza orientando la mirada a la persona humana" (p. 30).

7 En la Mater et magistra, el Papa no subraya solo el derecho de cada uno a la propiedad privada. Como ha notado Marianne Siegmond (2019): "el Pontífice une incesantemente los derechos con los deberes y su insistencia en el 
Otro derecho inherente a la dignidad humana era el de participar en la vida pública contribuyendo al bien común (Juan XXIII, 1963d, n.ํ26). Según el Papa (1963d), los gobernantes tenían un papel importante en relación con estos derechos y debían:

[...] de un lado, reconocer, respetar, armonizar, tutelar y promover los derechos de la persona humana; de otro, facilitar a cada ciudadano el cumplimiento de sus respectivos deberes. Tutelar el campo intangible de los derechos de la persona humana y hacerle llevadero el cumplimiento de sus deberes debe ser oficio esencial de todo poder público. (n. $\left.{ }^{\circ} 61\right)$

Este papel del Estado, según Juan XXIII (1963d), estaba apoyado y sostenido por las asociaciones y organizaciones intermedias, como partidos y sindicatos, que se describían como "instrumentos indispensables en grado sumo para defender la dignidad y libertad de la persona humana, dejando a salvo el sentido de la responsabilidad" (n. 는).

El Papa escribía que todos los seres humanos del mundo, en cuanto hijos del mismo padre celestial, gozaban de igual dignidad y por eso tenían el derecho a mudarse si las condiciones de sus países de origen no les permitían construirse una vida digna. En Pacem in Terris se encuentra así, la importante afirmación de que de la dignidad humana desciende el derecho a emigrar y Juan XXIII (1963d) recordaba que "es un deber de las autoridades públicas admitir a los extranjeros que llegan y, en cuanto lo permita el verdadero bien de su comunidad, favorecer los propósitos de quienes pretenden incorporarse a ella como nuevos miembros" (n. $\left.{ }^{\mathrm{o}} 106\right)$.

El Pontífice afirmaba, además, que el reconocimiento de la fraternidad universal de todos los seres humanos no solo les daba la misma dignidad, sino que convertía los derechos que derivaban de esta dignidad en derechos universales. Por eso, el Papa miraba con confianza y apoyaba la acción de las organizaciones interna-

derecho a la propiedad privada es un buen ejemplo. Mientras "la propiedad privada es claramente sancionada en el Evangelio", el Papa, a la vez, nota la invitación del Evangelio de Cristo a los ricos "para que conviertan sus bienes materiales en bienes espirituales entregándolos a los pobres" (Juan XXIII, 1961a, n.․121). 
cionales comprometidas en la defensa de estos derechos, primera entre estas la Organización de las Naciones Unidas (ONU) ${ }^{8}$.

Esta fraternidad universal no tenía que ver solo con las distinciones de tipo raciales, anuladas por el hecho de descender del mismo padre, sino que permitía al Papa decir que, en cuanto a la dignidad humana, hombres y mujeres tenían los mismos derechos ${ }^{9}$ aunque tuvieran funciones distintas. Al respecto, decía Juan XXIII (1961b):

El creador dio a la mujer dotes, inclinaciones y disposiciones naturales que son propias de ella [...] No distinguir esta diversidad de las respectivas funciones de hombres y mujeres y su necesaria complementariedad, significaría ponerse en contra de la naturaleza y terminaría degradando a la mujer y quitándole el verdadero fundamento de su dignidad. (pp. 611-612)

Las primeras características asociadas a la persona humana en la reflexión del Papa son, entonces, su dignidad, derivada del hecho de ser creada a imagen y semejanza de Dios, y los derechos inviolables y universales, "que no pueden renunciarse por ningún concepto" (Juan XXIII, 1963d, n. 9), procedentes de esta dignidad. Otro aspecto de la persona humana que se encuentra en el pensamiento de Juan XXIII es el hecho de que, si la dignidad humana es eterna e inmutable, la persona humana como tal, está insertada en un proceso continuo de maduración y perfeccionamiento.

La primera herramienta de desarrollo de la persona humana, según el Papa, es la constante santificación personal que se practicaba a través de la oración, de la contemplación, de la penitencia y de la ascesis, sin llegar a excesivas formas de

\footnotetext{
8 "Deseamos, pues, vehementemente que la Organización de las Naciones Unidas pueda ir acomodando cada vez mejor sus estructuras y medios a la amplitud y nobleza de sus objetivos. iOjalá llegue pronto el tiempo en que esta organización pueda garantizar con eficacia los derechos del hombre!, derechos que, por brotar inmediatamente de la dignidad de la persona humana, son universales, inviolables e inmutables" (Juan XXII, 1963d, ก. .0145$)$.

9 En la encíclica sobre la paz, el Papa (1963d) escribía: "es un hecho evidente la presencia de la mujer en la vida pública. Este fenómeno se registra con mayor rapidez en los pueblos que profesan la fe cristiana, y con más lentitud, pero siempre en gran escala, en países de tradición y civilizaciones distintas. La mujer ha adquirido una conciencia cada día más clara de su propia dignidad humana. Por ello no tolera que se la trate como una cosa inanimada o un mero instrumento; exige, por el contrario, que, tanto en el ámbito de la vida doméstica como en el de la vida pública, se le reconozcan los derechos y obligaciones propios de la persona humana" (n.ำ 41).
} 
mortificación, "que sujeten o mortifiquen la adulta personalidad de cada uno" (Juan XXIII, 1959f, p. 202). La santificación permite a la persona mantener su cercanía con Dios y es fortalecida y alimentada por la Eucaristía, que el Papa sugería, fuera un hábito frecuente de los cristianos ${ }^{10}$.

Aunada a la santificación personal, que constituía la tarea principal de cada ser humano, el Pontífice ponía su atención en cuatros "lugares" donde la persona podía crecer y fortalecerse desde un punto de vista espiritual católico: la familia, la escuela, la parroquia y los ambientes de trabajo. La familia la definía como un ambiente natural para "el desarrollo de la persona humana y providencial refugio en el que se aplacan y se endulzan las tempestades de la vida, se apagan las tentaciones de las inclinaciones indisciplinadas y se combaten los influjos de los malos ejemplos" (Juan XXIII, 1959e, p. 196).

En los colegios, los maestros estaban llamados a apoyar este esfuerzo de las familias por medio de un testimonio serio y entregado de su fuerte personalidad cristiana (Juan XXIII, 1959o, p. 705). El Pontífice (1960b) recordaba también a todos los educadores y, en particular, a los directores espirituales, la importancia de desarrollar una educación íntegra que incluyera la formación de la inteligencia, la voluntad y los afectos, y de poner en práctica una pedagogía de la vida espiritual en la que "[...] el joven adquiera conciencia de la correspondencia que existe entre las verdades que se le enseña a creer y las aspiraciones interiores que brotan de su personalidad hacia ideales de justicia, de caridad y rectitud moral" (p. 101).

La familia y los lugares de formación de la juventud eran fundamentales en el primer desarrollo de la persona y el Papa subrayó a menudo esta importancia. Sin embargo, Juan XXIII pareció, entre 1959 y 1963, enfocar más su atención en los ambientes de trabajo, vistos como los medios en donde se jugaba "el partido espiritual" más importante para la dimensión trascendente de los seres humanos

10 Precisamente, el Papa (1959d), escribía: “La Eucaristía, infundiendo en el corazón del hombre una nueva energía, el amor sobrenatural, refuerza, al mismo tiempo que encauza, y purifica el afecto humano, haciéndolo más sólido, más auténtico. Es el hombre todo, cuando en su pecho tiene a Dios, el que queda en sí mismo armonizado, robusteciéndose su personalidad, con lo que las mismas virtudes naturales se elevan de rango y son estimuladas hasta madurar el tipo ideal de hombre perfecto hecho a imagen de Dios y conformado al ejemplar de su hijo en quien el padre tiene todas sus complacencias" (p. 207). 
de la segunda mitad del siglo XX. En la fase histórica representada por los años sesenta de 1900, Estados Unidos y Europa occidental estaban viviendo un rápido proceso de crecimiento económico desencadenado por la expansión industrial que, por un lado, estaba fomentando el desarrollo urbano y la crisis de la sociedad campesina, y, por el otro, iba introduciendo enormes cambios en los estilos de vida, modificando profundamente el sentido religiosoll de las mujeres y los hombres europeos y estadounidenses.

Este cambio le interesaba mucho al Papa lombardo, el cual, además de convocar el Concilio para dar a la Iglesia mejores instrumentos para desarrollar la acción pastoral en estos contextos, reflexionó sobre los aspectos positivos y negativos, desde un punto de vista de la maduración de la persona en una perspectiva cristiana, presentes en los lugares de trabajo. Estos fueron indicados ya en 1959 como ambientes de posible perfeccionamiento moral de la persona, si se construían relaciones laborales basadas en la fraternidad y colaboración entre patrones y obreros. Reforzaba el Papa (1959n) que sin estas dos virtudes “[...] no se puede alcanzar una concepción verdaderamente cristiana del trabajo humano, por lo que eso trae a la persona del hombre redimido a una conciencia cada día más clara de su responsabilidad y, a la vez, de su propia dignidad" (pp. 821-822). Además, el "Papa bueno" (1959m), recordaba que:

[...] a todos aquellos sobre los que gravan la mayor parte de las responsabilidades en la empresa, y de los que depende algunas veces también la vida de los obreros, a que no consideren a los trabajadores solamente desde el punto de vista económico y a que no se limiten al reconocimiento de sus derechos relacionados con el justo salario, sino a que respeten además la dignidad de su persona y los miren como a hermanos.

Así, según Juan XXIII (1959m), se lograría que “al feliz desarrollo alcanzado en el nivel económico corresponda no un menor progreso en el campo de los valores morales, como lo requiere la dignidad misma del cristiano; más aún la misma dignidad humana". El Estado tenía el cargo de apoyar y recordar a los empleadores esta necesidad y, en Mater et magistra, el Papa (196la) escribía que debía vigilar, 
discreta pero constantemente, que "en los ambientes laborales no sufra mengua, ni en el cuerpo ni en el espíritu, la dignidad de la persona humana” (n.ํ2).

Mientras que muchos, también adentro de la Iglesia, miraban con miedo al declive de la sociedad rural y condenaban el consiguiente ingreso en las fábricas de miles de campesinos, fácil objetivo de la propaganda anticlerical, Juan XXIII tenía una visión problemática de la industrialización. El Papa trataba de mantener un equilibrio entre el reconocimiento de los aspectos positivos del progreso material determinado por el crecimiento manufacturero y la preocupación causada por la crisis de la sociedad campesina y la descristianización de los obreros. Según el Pontífice (196la), de hecho, el progreso favorecido por el desarrollo industrial, permitía una mejor satisfacción de los derechos relacionados con la dignidad de la persona, sobre todo:

[...] los llamados económico-sociales, los cuales atienden fundamentalmente a las exigencias de la vida humana: el cuidado de la salud, una instrucción básica más profunda y extensa, una formación profesional más completa, la vivienda, el trabajo, el descanso conveniente y una honesta recreación. (n.. 61)

La visión del Papa era compleja y espejo de los difíciles y contradictorios años en que vivía en los cuales la Iglesia y la sociedad eran sacudidas por tendencias contrapuestas y divididas entre el intento de abrirse a la novedad y la continua tentación de permanecer agarrados a la tradición. Juan XXIII, por eso, unía al reconocimiento de los aspectos positivos del progreso y a la convicción de que, como escribe Tineo (1997), "la Iglesia es joven y conserva, como siempre a lo largo de su historia, su capacidad para el cambio" (p. 153) la condena a los rasgos negativos y anticristianos de la "modernidad industrial" que peligraban la dignidad de la persona humana. Juan XXIII (1962b, p. 460) subrayaba los peligros que amenazaban los jóvenes campesinos que entraban en las grandes industrias y que, viviendo lejos de sus familias y de sus parroquias corrían el riesgo de perder su dignidad. Siguiendo este "equilibrio complejo", además, el Pontífice reconocía que en las fábricas se desarrollaban fácilmente ideologías anticristianas y por eso invitaba a los que podían, que se quedaran en el campo. El trabajo rural permanecía como valioso instrumento de santificación y elevación personal que permitía a los cam- 
pesinos luchar contra "una peligrosa mentalidad que insidiaba los valores más sagrados de la persona humana" (Juan XXIII, 1959h).

En el periodo temporal elegido para esta investigación, el Papa recordaba la crítica a los sistemas políticos que negaban la dignidad humana y ya el 25 de enero de 1959 condenó las ideologías que "imponen el sacrificio de la libertad de pensamiento, de acción cívica y social y, con especial ensañamiento, de profesar libremente su fe" ya que esto provocaba solo "miedo, violencias y anonadamiento de la persona humana” (Juan XXIII, 1959a, p. 72). En 1960 reprobó las tendencias ideológicas "exaltantes por un lado la libertad desenfrenada, por el otro la supresión de la personalidad que le quitan al trabajador su dignidad, reduciéndolo a un instrumento de lucha" (Juan XXIII, 1960c, p. 398)12 y criticó los intentos de dañar a la familia, a las minorías étnicas, a la religión y a la Iglesia. Para el Papa estos intentos destructivos eran la causa de los males de la actual sociedad (Juan XXIII, 1960a, p. 31).

Dos años después, recordó que "si del respeto a la persona se pasa a la exaltación de la personalidad y a la afirmación del personalismo, los peligros se hacen graves" (Juan XXIII, 1962e, p. 514) y desaprobó las doctrinas "partidarias del indiferentismo religioso o negadoras de Dios y del orden sobrenatural y las doctrinas que ignoran la Providencia en la historia y exaltan inconsideradamente la persona" (Juan XXIII, 1962f, p. 682).

La reflexión de Angelo Roncalli sobre el concepto de persona se enfocaba entonces alrededor de la dignidad humana, de los instrumentos y lugares de formación y maduración de la persona y de los peligros que amenazaban su correcto y cristiano desarrollo. Además de estas tres grandes categorías, hay otros casos en que el Papa empleaba la palabra persona, que es importante subrayar porque permite profundizar el conocimiento de su pontificado.

12 El Papa (1960c) seguía diciendo que estas ideologías trataban de "sembrar discordia contraponiendo las distintas categorías de la vida social y alejar las masas trabajadoras de aquel Dios que es el único protector y vengador de los humildes y que nos da la vida, el movimiento y la existencia, como si la condición de trabajadores obligue eximirse de conocerle, amarle y servirle" (p. 399). 
Juan XXIII (1962a) empleó este término para recordar cómo la persona del Papa recibía de san Pedro la autoridad de las llaves, o sea "el gobierno universal de la Iglesia” (pp. 167-168), conferida por Cristo directamente al príncipe de los apóstoles. En una sociedad que iba hacia el periodo de 1968-1969, caracterizado por una fuerte contestación de toda jerarquía, inclusive la de la institución eclesiástica, Juan XXIII usaba este concepto para confirmar que el Pontífice seguía manteniendo el máximo poder en la Iglesia, cuya autoridad se difundía a los obispos.

El segundo caso es constituido por una variante de la palabra persona que es personalidad ${ }^{13}$ y el Papa (1960e) escribía que la fe en la Virgen representaba el "elemento básico de la cultura y el dato fundamental de la personalidad" (p. 981) latinoamericana. El tercer caso tenía que ver con Estados Unidos, de tal modo que, en uno de los últimos discursos antes de fallecer, el Pontífice (1963c) se alegró con un grupo de peregrinos de este país, comentando que la legislación estadounidense "desciende de los principios de la moral cristiana y cada día tiene un contenido más correspondiente a la dignidad de la persona humana” (p. 329).

\section{La felicidad terrenal y el gozo celestial en el pensamiento de Juan XXIII}

La reflexión sobre el concepto de felicidad constituye otro de los aspectos característicos de todo el pensamiento de Angelo Roncalli y la atención a este tema se encuentra ya en sus cartas juveniles como demuestra el Decálogo de la serenidad ${ }^{14}$.

13 En el marco del pensamiento católico el concepto de personalidad del ser humano indica: "aquello de lo que tiene conocimiento bajo el concepto del 'yo'. Es esa entidad, sustancial, permanente, unitaria, que es el sujeto de todos los estados y actos que constituyen su vida completa" (Enciclopedia católica en línea).

14 Muy joven, Roncalli escribió este decálogo constituido por diez consejos para conseguir la felicidad terrena y eterna. El decálogo, citado por Martín Descalzo (s. f.), reporta. "1. Solo por hoy trataré de vivir exclusivamente al día, sin querer resolver los problemas de mi vida todos de una vez; 2. Solo por hoy tendré el máximo cuidado de mi aspecto: cortés en mis maneras, no criticaré a nadie y no pretenderé criticar o disciplinar a nadie, sino a mí mismo; 3. Solo por hoy seré feliz en la certeza de que he sido creado para la felicidad, no solo en el otro mundo, sino en este también; 4. Solo por hoy me adaptaré a las circunstancias, sin pretender que las circunstancias se adapten todas a mis deseos; 5 . Solo por hoy dedicaré diez minutos a una buena lectura; recordando que, como el alimento es necesario para la vida del cuerpo, así la buena lectura es necesaria para la vida del alma; 6 . Solo por hoy haré una buena acción y no lo diré a nadie; 7 . Solo por hoy haré por lo menos una cosa que no deseo hacer, y si me sintiera ofendido en mis sentimientos, procuraré que nadie se entere; 8 . Solo por hoy me haré un programa detallado. Quizá no lo cumpliré cabalmente, pero lo redactaré. Y me guardaré de dos calamidades: la prisa y la indecisión; 9. Solo por hoy creeré firmemente, aunque las circunstancias demuestren lo contrario, que la buena providencia 
Una vez elegido Papa, Juan XxIII (1962c, p. 441) aclaraba que ya habían perdido fuerzas las tendencias filosóficas de los siglos XVIII y XIX que pensaban que la única forma de felicidad posible en este mundo se podía alcanzar por medio de la ciencia y de la razón. Por lo tanto, frente al fracaso de estas filosofías, el Papa (1962g) planteaba una concepción de felicidad en la que la Iglesia:

[...] no ofrece riquezas caducas a los hombres de hoy, ni les promete una felicidad solo terrenal; los hace participes de la gracia divina que, elevando a los hombres a la dignidad de hijos de Dios, se convierte en poderosísima tutela y ayuda para una vida más humana; abre la fuente de su doctrina vivificadora que permite a los hombres, iluminados por la luz de Cristo, comprender bien lo que son realmente, su excelsa dignidad, su fin.

Las vías para la felicidad ultraterrenas fueron mostradas a los cristianos por Jesús y la Virgen. El Pontífice (1959g), de hecho, escribía que Jesús era "vía de santa conversación, verdad de doctrina de vida, vida de felicidad sempiterna” (p. 254) y que separados de Cristo no había paz ni felicidad (Juan XXIII, 1960a, p. 32) ${ }^{15}$. Jesús había ilustrado a todos los fieles del mundo la vía a la felicidad en el Padre Nuestro que enseñaba a los seres humanos a unir perfectamente su voluntad a la del padre (Juan XXIII, 196ld, p.766). Los cristianos podían recorrer esta vía fortalecidos por el auxilio del Espíritu Santo que, "los sostiene en las luchas y los hace sobrepasar felizmente las contradicciones y las dificultades" (Juan XXIII, 1959i, p. 354). También la Virgen tenía un papel en el acompañamiento de los cristianos en esta vía que conducía a la verdadera felicidad y, según el Papa (1959c), había mostrado a Bernadette en Lourdes cómo hacer para recorrerla. La clave consistía en aceptar:

[...] el destino de su vida, no por alcanzar la felicidad en este mundo, sino que para alcanzar la gloria y el gozo celestial. Esta invitación constituye el precioso depósito de

\footnotetext{
de Dios se ocupa de mí, como si nadie más existiera en el mundo; 10. Solo por hoy no tendré temores. De manera particular no tendré miedo de gozar de lo que es bello y de creer en la bondad".

15 En el mensaje para la vigilia de Navidad el Papa (1960a) dijo: "la paz es la feliz heredad de los que cumplen la ley divina [...] sin embargo la pacificación anhelada por la Iglesia no puede, de ninguna manera confundirse con un relajamiento de su firmeza hacia ideologías y sistemas de vida que están en oposición irreductible con la doctrina católica ni significa indiferencia hacia el grito que llega hasta nosotros de las regiones infelices, donde los derechos del hombre son ignorados, la mentira es la base del sistema" (p. 32).
} 
doctrina y de gracias reservados a la práctica de vida cristiana de cada hombre, invitado a salir de la tiniebla para ver la luz. (p. 137)

Los cristianos, apoyados por estas grandes ayudas, a las que se unía también el ejemplo de los santos, debían ya en esta tierra buscar la felicidad teniendo "el alma orientada hacia Dios" (Juan XXIII, 1959l, p. 356) ${ }^{16}$ y esforzándose por santificarse ellos mismos y a los hermanos, mediante la oración, la práctica de las cuatro virtudes cardinales (prudencia, justicia, fortaleza y templanza) y de las obras de caridad $^{17}$. Este esfuerzo no podía dar frutos alejándose de la Iglesia ${ }^{18}$ porque:

[...] quienes pertenecen con realidad y eficacia al cuerpo místico de Jesucristo, que es la Iglesia católica, participan de esa vida, que desde la divina cabeza se difunde hasta cada miembro, y, por razón de ella, quienes obedecen fielmente a todos los preceptos y mandatos de nuestro redentor también en esta vida mortal pueden gozar de aquella alegría que es auspicio y preanuncio de la celestial y sempiterna felicidad. (Juan XXIII, 1959m)

El Papa (1960f) invitaba a los fieles a cultivar la felicidad obtenida, mirando "en las cosas el bien y fijándose en eso, en cambio a buscar el mal y el defecto y, subrayarlo con ligereza, peor aún con malicia" (p. 237). Este "cultivo" no podía limitarse a la esfera individual, sino que la felicidad tenía que convertirse en una fuerza capaz de cambiar el mundo por medio de la búsqueda incansable de la felicidad y salvación del hermano "en cuya persona se ve al Divino Maestro" (Juan XXIII, 1959q, p. 910).

Todos los cristianos estaban llamados a buscar la felicidad terrena y cultivarla siguiendo las recomendaciones de la Iglesia. Sin embargo, tenían que ser conscientes de que la felicidad terrena era:

[...] aún imperfecta. Porque es paz no completamente tranquila, no del todo serena; es paz laboriosa, no ociosa, ni inerte; es, sobre todo, paz militante contra todo error,

16 El Papa (1959l) decía también que "la verdadera felicidad del hombre, la que perdura también en medio de las vicisitudes penosas de la vida, está en el nunca dejar de mirar al fin supremo" (p. 358).

17 Juan XXIII (1962i) añadía que sobre las cuatro virtudes cardinales "se basa como monumento indestructible el honor de una diócesis (¿qué estamos diciendo?) el honor de un pueblo fuerte y digno, cuyo esfuerzo el Señor asegura corona de méritos y asesoría celestial, que sirven para la vida presente y son prenda de felicidad para la futura" (p. 659).

18 Inaugurando las labores del Sínodo Diocesano de Roma Juan XXIII (1960d) dijo: "Queridísimos hijitos, ipermanezcamos fieles a Cristo y a su Iglesia santa y bendita y seremos salvos, y seremos felices!" (p. 235). 
aunque disimulado bajo falsa apariencia de verdad, contra los estímulos y halagos de los vicios, y, en fin, contra toda clase de enemigos del alma, que puedan debilitar, manchar o destruir nuestra inocencia y nuestra fe católica; y también contra los odios, las enemistades, las divisiones que pueden quebrantar o lacerar la misma fe. (Juan XXIII, 1959m) ${ }^{19}$

La plena e imperecedera felicidad estaba en el otro mundo mientras que en este encontraba muchos enemigos que estaban adentro y afuera del alma humana. Los enemigos internos acabamos de mencionarlos, mientras que los externos eran las divisiones en la Iglesia y fuera de ella. El Papa (1959b, p. 132) pronunció una dura crítica a todos aquellos bautizados que se alegraban de las tensiones descritas por la prensa entre los obispos y entre los obispos y el Papa y los llamaba falsos católicos ${ }^{20}$.

Juan XXIII (1959a), además, escribía que también las divisiones entre los cristianos iban en contravía del plan de Dios y de la obra apostólica de san Pablo y, en 1959, afirmó que "los atentados y los esfuerzos de romper la compacidad católica son perjudiciales de la felicidad y del bienestar del mundo concebidos por Jesús como un solo redil bajo la guía de un solo pastor" (p. 72).

En este pontificado, por lo tanto, se utilizó a menudo la palabra felicidad para describir la más alta meta que tenían que alcanzar los cristianos también, aunque casi nunca el Papa usara las bienaventuranzas para describir su concepción de la felicidad cristiana ${ }^{21}$. Esta característica fue pronto reconocida por el ministro de

19 En esta parte del texto, el Papa (1959m) usaba los términos paz y felicidad como sinónimos. Lo demuestra el íncipit de la frase: "Pero esta paz, esta felicidad, mientras recorremos penosamente el camino de nuestro terreno destierro, es aún imperfecta”.

20 En este documento, el Papa (1959b) añadía que el Concordato entre Italia y la Santa Sede de 1929 era: "un hecho que afirmó por Italia la feliz alianza entre Iglesia y Estado" (p. 133).

21 La única citación que encontré de una bienaventuranza está en la encíclica sobre el apostolado misionero en la que se habla de las persecuciones anticatólicas en las tierras de misiones. El Papa (1959p) escribía: "Muchas diócesis y comunidades cristianas de las tierras de misión soportan sufrimientos y persecuciones hasta sangrientas: a los sagrados pastores que dan a sus hijos espirituales el ejemplo de una fe que no se deja doblegar y de una lealtad que jamás falla ni aun a precio del sacrificio de la vida; a los fieles tan duramente probados, más tan amados por el Corazón de Jesucristo que ha prometido la felicidad y una copiosa merced a quienes sufrieren persecuciones por causa de la justicia (cf. Mt 5,10-12), dirigimos nuestra exhortación para que perseveren en su santa batalla: el Señor, siempre misericordioso en sus inescrutables designios, no dejará que les falte el socorro de las más preciosas gracias y de la íntima consolación. Con los perseguidos se halla en comunión de oraciones y de sufrimientos toda la Iglesia de Dios, segura de lograr la esperada victoria”. 
Asuntos Exteriores de Bolivia, José Fellman Velarde (1963), que en el telegrama enviado en ocasión de la muerte del Pontífice escribió:

Tengo sentimiento expresar Vuestra Eminencia sentida condolencia fallecimiento Romano Pontífice Su Santidad Juan XXIII, cuya excelsa misión en Concilio ecuménico en pro pacificación universal y resurgimiento social pueblos constituye luminoso derrotero legado humanidad consecución felicidad y justicia que el pueblo boliviano aprecia devotamente. (p. 519)

\section{Discusión de los resultados}

Considero que la presente investigación contribuye a demostrar la importancia de los conceptos de persona y felicidad en el pensamiento del Papa, a la luz del Concilio Vaticano II. La persona, especialmente su dignidad, es la base de las preocupaciones pastorales de Angelo Roncalli. El Pontífice, de hecho, se hizo constante defensor de los derechos inherentes al hecho de que el ser humano es creado a imagen y semejanza de Dios, retomando así un rasgo peculiar de los pontificados de Benedicto XV, Pío XI y Pío XII. Si Papa Della Chiesa miró con angustia a las violaciones de la dignidad humana en la primera guerra mundial; Achille Ratti escribió unas encíclicas como la Mit brennender Sorge, en las que aclaraba la distancia entre el catolicismo y las ideologías racistas y totalitarias. Eugenio Pacelli trató en todos modos de aliviar el sufrimiento de millones de personas en la segunda guerra mundial, también Angelo Roncalli se puso en la misma línea mirando con creciente preocupación las tensiones provocadas por el enfrentamiento entre Estados Unidos y la Unión Soviética. Por eso, Juan XXIII fortaleció la reflexión pontificia sobre el tema de la dignidad humana por medio de unos importantes documentos como la Mater et magistra y la Pacem in Terris.

Y icómo se defendía la dignidad humana en los años sesenta del siglo XX? Según el Papa, frente a las tensiones de la guerra fría, que alcanzaron su acmé en 1962 con la crisis de los misiles de Cuba, se tenía que trabajar sin parar para construir la paz por medio del diálogo. Esta paz se edificaba en las relaciones internacionales por medio de la actividad mediadora de la ONU; en las dimensiones sociales menos patentes, como la familia y los lugares de trabajo. En el contexto de la 
construcción de un mundo en paz y armonía, la Iglesia tenía un papel importante como fuerza mediadora entre las dos superpotencias y en la sociedad que valorizaría sobre todo Pablo vi con la Ostpolitik, o sea, el diálogo entre la Santa Sede y la Unión Soviética, impulsado por Montini por medio de su secretario de Estado, cardenal Agostino Casaroli, y con su compromiso personal para acercar la Iglesia a los obreros, según una intuición ya puesta en práctica en los años del episcopado ambrosiano (Ferrari, 2017a).

Juan XXIII, entonces, pensaba que la Iglesia podía desempeñar un papel importante en la defensa y promoción de la dignidad de la persona humana; sin embargo, estaba convencido de que necesitaba actualizar unos aspectos de su actividad pastoral y por eso decidió convocar un concilio ecuménico el 25 de enero de 1959. El Papa sentía la necesidad de impulsar esta actualización para permitir que la Iglesia fortaleciera su papel de defensora de la dignidad humana y, por medio de esta acción, permitiera a los hombres y a las mujeres alcanzar la verdadera felicidad. Este gozo, esta alegría no eran los propuestos por el mundo filosófico del siglo precedente, ni los ofrecidos por el sistema capitalista en fuerte expansión en todo el "mundo libre". Era una felicidad distinta y que tenía su mirada bien fija en la doctrina de Jesús y en la promesa cristiana de la vida eterna. La Iglesia tenía el papel de enseñar a los seres humanos de la segunda mitad del siglo xx la vía para alcanzar esta felicidad; no obstante, el Papa se daba cuenta que, tanto en la Europa occidental y los Estados Unidos la predicación católica ya no llegaba a la mayoría de los hombres y mujeres contemporáneos, debido a la secularización de la sociedad como en América Latina y África, la descolonización y emersión de las voces y teologías de las culturas extraeuropeas. Por este motivo, Juan XXIII convocó el Concilio para actualizar y dar al catolicismo nuevos instrumentos para que el mensaje cristiano penetrara en las conciencias y acciones de los coevos seres humano y, por eso, se puede decir que la idea misma del Vaticano II está muy relacionada con la concepción de persona y felicidad planteada por Angelo Giuseppe Roncalli. 


\section{Conclusiones}

Llegando al final de esta investigación se puede concluir que en la reflexión magisterial propuesta por Juan XXIII la persona humana ocupa un lugar central. En este sentido, el Pontífice "se sitúa en la línea tradicional de la Iglesia, de los papas anteriores y muy concretamente de León XIII y Pío XII, pero actualizándola y proyectándola sobre los problemas vitales del mundo presente" (Bernárdez-Cantón, 1964, p. 181), problemas y nuevos retos como el respaldo a la acción promovida por la ONU, la interpretación del movimiento migratorio como derecho derivado de la dignidad humana y la igualdad, si bien con diferentes funciones, entre hombres y mujeres.

Además de estos aspectos importantes, según mi opinión, el rasgo del pontificado de Angelo Giuseppe Roncalli más interesante subrayado por la investigación presentada, es el intento de Juan XXIII de mantener un equilibrio entre el estímulo al progreso industrial y la condena a las concepciones socioeconómicas marxistas y anticlericales.

Frente a un mundo católico, en el que una parte importante condenaba sin muchas reflexiones el ingreso de miles de campesinos en las fábricas y la penetración en este grupo social de la ideología comunista, el Papa trataba de subrayar los aspectos positivos de la industrialización. A pesar de las numerosas condenas pronunciadas por Juan XXIII contra de las tendencias marxistas basadas en la contraposición clasista, del individualismo capitalista y del ateísmo, el Pontífice pedía a todos los católicos que empezaran a reconocer los "signos de los tiempos"22 disintiendo de:

22 La fórmula "signos de los tiempos" encuentra su origen en el capítulo XVI, versículos 2 y 3 del Evangelio según san Mateo en el que Jesús, hablando a los fariseos y saduceos, decía: "Cuando los celajes del atardecer parecen de fuego, ustedes dicen: 'Tendremos buen tiempo'. Y cuando, por la mañana, el cielo está de un rojo sombrío, dicen: 'Hoy tendremos tormenta'. Así que saben interpretar el aspecto del cielo y, en cambio, no son capaces de interpretar los signos de los tiempos". En la Navidad de 1961, Juan XxIII citaba esta enseñanza para afirmar su voluntad de seguir "la recomendación de Jesús cuando nos exhorta a distinguir claramente los signos... de los tiempos (Mt 16,3). Nos creemos vislumbrar, en medio de tantas tinieblas, no pocos indicios que nos hacen concebir esperanzas de tiempos mejores para la Iglesia y la humanidad" (Juan XXIII, 196lc). Según EspinosaArce (2016), "De la palabra de Juan XXIII, se extraen las siguientes consecuencias. En primer lugar, el afirmar que el reconocimiento de la Iglesia de las realidades temporales se realiza a la luz de la fe. Los cambios profundos deben pensarse desde el Evangelio. También se concluye que el discernimiento de los "signos de los tiempos" 
[...] tales profetas de calamidades, avezados a anunciar siempre infaustos acontecimientos, como si el fin de los tiempos estuviese inminente. En el presente momento histórico, la Providencia nos está llevando a un nuevo orden de relaciones humanas que, por obra misma de los hombres, pero más aún por encima de sus mismas intenciones, se encaminan al cumplimiento de planes superiores e inesperados; pues todo, aun las humanas adversidades, aquella lo dispone para mayor bien de la Iglesia. (Juan XXIII, 1962g)

Y según el Papa icuál era la máxima autoridad encargada de interpretar los “signos de los tiempos"? Este papel era desempeñado por la Iglesia católica que, basada sobre una jerarquía establecida por Cristo que veía en su vértice al Papa, era la única institución con las herramientas para desarrollar una acción que respetara la dignidad de la persona humana y permitiera a los seres humanos alcanzar la verdadera felicidad que no estaba en este mundo, sino en el otro.

Esta concepción del Papa era amenazada y debilitada por la secularización de las sociedades y por las crecientes divisiones dentro de la Iglesia, entre quienes estaban a favor de las tendencias sociales novedosas determinadas por el progreso industrial y estaban comprometidas en la defensa de la dignidad humana $\mathrm{y}$, entre quienes tenían miedo de que tal aliciente pudiera dividir a la Iglesia y fortalecer a sus adversarios. Ya durante el pontificado de Roncalli se empezó a ver que en el catolicismo existían distintos modos de interpretar este complejo y, quizá, irrealizable equilibrio entre novedad y tradición y el Papa no logró pacificar los frentes contrapuestos. Las tensiones se exacerbaron en los años siguientes a la muerte de Juan XXIII convirtiéndose rápidamente en uno de los principales motivos del último cisma católico —el del grupo conservador ligado a monseñor Marcel Lefebvre- y de las fracturas que afectaron y siguen afectando el catolicismo después del cierre del Concilio Vaticano II.

Concluyendo, se puede afirmar que los conceptos de persona y felicidad tienen un papel importante en el pontificado de Juan XXIII, el cual profundizó y problematizó la reflexión magisterial sobre estos temas, abriendo a la Iglesia una vía compleja pero obligada a seguir cumpliendo la "gran misión de llevar un acento humano 
y cristiano a la civilización moderna; acento que la misma pide y casi invoca para sus progresos positivo y para su misma existencia" (Juan XXIII, 196la, n.ํ256).

\section{Referencias $^{23}$}

Agustín de Hipona. (390). El sermón de la montaña, vol. I, cap. l. https://www.augustinus.it/spagnolo/montagna/index $2 . h t m$

Batelli, G. (1993). Pio XI e le Chiese non occidentali. La questione dell'universalità del cattolicesimo. Studi Storici, 34(1), 193-218.

Bernárdez-Cantón, A. (1964). Iglesia y Estado en Juan XXIII. Ius Canonicum, 4(7), 165-181.

Blot, D. (2010). El cura de Ars en el magisterio pontificio de san Pío X a Benedicto XVI. Anuario de Historia de la Iglesia, 19, 267-275.

Britto, R. (2010). Common good. A moral category in the social thought of John Paul II. Journal of Dharma, 35(4), 405-420.

Canepa, A. M. (1992). Pius X and the Jews. A reappraisal. Church History, 61(3), 363-372.

Catecismo de la Iglesia católica, 1992, n. .0 1700. http://www.vatican.va/archive/catechism_sp/p3slcl_sp.html Chenaux, P. (2016). Pablo VI y la libertad religiosa. Anuario de Historia de la Iglesia, 25, 193-207.

Coppa, F. J. (2003). Pio IX and the Jews. From "reform" to "reaction" (1846-1878). Catholic Historical Review, 89(4), 671-695.

Coppa, F. J. (2011). The National Edition of the Diaries of Angelo Giuseppe Roncalli. Catholic Historical Review, 97 (1), 81-92.

De Cesaris, V. (2011). L'Eglise de Pie XI et l'antisémitisme fasciste. Revue d'Histoire Ecclésiastique, 106(3-4), 521-545.

Enciclopedia católica online. (2021). Voz "Personalidad". Recuperado de https://ec.aciprensa.com/wiki/ Personalidad

Espinosa-Arce, J. P. (2016). “Signos de los tiempos” en Gaudium et Spes. Redacción, hermenéutica y teología. Espiga, 15(32), 1-15.

Fellman Velarde, J. (1963). Telegrama en ocasión del fallecimiento del Sumo Pontífice Juan XXIII. AAS, LV(5), 519. http://www.vatican.va/archive/aas/documents/AAS-55-1963-ocr.pdf.

Ferrari, F. (2017a). Attivismo, orgoglio e tradizione ambrosiana. I cattolici nelle fabbriche milanesi dal secondo dopoguerra al Concilio Vaticano II. Roma : Studium.

23 Con la sigla AAS se entienden las Actas Apostolicae Sedis. Las traducciones de los textos indicados en idiomas distintos fueron realizadas por el autor. 
Felicidad, empatía y solidaridad personal frente al trauma sociocultural de la pandemia en Italia

Ferrari, F. (2017b). Benedetto XV, l'impero asburgico e la I Repubblica austriaca. En A. Melloni (ed.), Benedetto XV. Papa Giacomo Della Chiesa nel mondo dell' "inutile strage", vol. II (pp. 793-804). Bolonia: Il Mulino.

Ferrari, F. (2018). "I was a stranger and you welcomed me". The Papal Magisterium and Human Mobility from Leo XIII to Paul VI (1878-1978). Journal of Mediterranean Knowledge-JMK, 3(2), 155-177.

Francisco. (2013). Exhortación apostólica Evangelii gaudium del Santo Padre Francisco sobre el anuncio del Evangelio en el mundo actual (24 de noviembre de 2013). http://www.vatican.va/content/francesco/es/ apost_exhortations/documents/papa-francesco_esortazione-ap_20131124_evangelii-gaudium.html

Francisco. (2018). Exhortación apostólica Gaudete et exsultate del Santo Padre Francisco sobre el llamado a la santidad en el mundo actual (19 de marzo de 2018). http://www.vatican.va/content/francesco/es/apost exhortations/documents/papa-francesco_esortazione-ap_20180319_gaudete-et-exsultate.html

García-Alandete, J. (2018). El magisterio de Pío XII sobre psicología y psicoterapia. Espiritu, 67(156), 493-517.

Juan XXIII. (1959a). Homilía en la fiesta de la conversión de san Pablo (25 de enero de 1959). AAS, LI(1), 7074. Texto original en italiano. http://www.vatican.va/archive/aas/documents/AAs-51-1959-ocr.pdf.

Juan XXIII. (1959b). Carta a los obispos de Italia para el aniversario de la firma de los Pactos lateranenses (6 de febrero de 1959). AAS, LI(1), 131-133. Texto original en italiano, http://www.vatican.va/archive/ aas/documents/AAs-51-1959-ocr.pdf.

Juan XXIII. (1959c). Alocución en ocasión del aniversario de las apariciones de la Virgen en Lourdes (15 de febrero de 1959). AAS, LI(1), 135-139. Texto original en italiano. http://www.vatican.va/archive/aas/ documents/AAs-51-1959-ocr.pdf

Juan XXIII. (1959d). Mensaje a los participantes al I Congreso Eucarístico Centroamericano de Guatemala (15 de febrero de 1959). AAS, LI(1), 207. http://www.vatican.va/archive/aas/documents/AAS-511959-ocr.pdf

Juan XXIII. (1959e). Alocución a las representantes del Centro Italiano Femenino (1. de marzo de 1959). AAS, LI(1), 195-197. Texto original en italiano. http://www.vatican.va/archive/aas/documents/AAs-511959-ocr.pdf

Juan XXIII. (1959f). Alocución a la Unión del Clero por el I Centenario de la muerte de san Juan María Vianney (12 de marzo de 1959). AAS, LI(1), 198-202. Texto original en italiano. http://www.vatican.va/ archive/aas/documents/AAS-51-1959-ocr.pdf

Juan XXIII. (1959g). Homilía en la misa Pascual (29 de marzo 1959). AAS, LI(1), 250-257. Texto original en italiano. http://www.vatican.va/archive/aas/documents/AAs-51-1959-ocr.pdf

Juan XXIII. (1959h). Discurso a los miembros de la Confederación italiana de Cultivadores (22 de abril de 1959). AAS, LI(l), Texto original en italiano. http://www.vatican.va/archive/aas/documents/AAS51-1959-ocr.pdf 
Juan XXIII. (1959i). Alocución de a los fieles de Lucca para la canonización de Elena Guerra (27 de abril de 1959). AAS, LI(l), 353-355. Texto original en italiano. http://www.vatican.va/archive/aas/documents/ AAS-51-1959-ocr.pdf

Juan XXIII. (1959l). Alocución a los miembros de las ACLI en ocasión de la fiesta de 1.ํ de mayo de 1959. AAS, LI(l), 355-359. Texto original en italiano. http://www.vatican.va/archive/aas/documents/AAS51-1959-ocr.pdf.

Juan XXIII. (1959m). Carta encíclica Ad Petri Cathedram de nuestro Señor Juan por la divina Providencia Papa xxIII sobre la verdad, unidad y paz que se han de promover con Espíritu de caridad (29 de junio de 1959). https:// w2.vatican.va/content/john-xxiii/es/encyclicals/documents/hf_j-xxiii_enc_29061959_ad-petri.html Juan XXIII. (1959n). Alocución a los caballeros del trabajo, a los maestros del trabajo de Italia y a los trabajadores mayores de industria (17 de octubre de 1959). AAS, LI(1), 821-822. Texto original en italiano. http://www.vatican.va/archive/aas/documents/AAs-51-1959-ocr.pdf

Juan XXIII. (1959o). Alocución a la Unión de los maestros católicos italiano (6 de septiembre de 1959). AAS, LI(l), 703-706. Texto original en italiano. http://www.vatican.va/archive/aas/documents/AAS51-1959-ocr.pdf

Juan XXIII. (1959p). Carta encíclica Princeps pastorum de Su Santidad Juan XXIII sobre el apostolado misionero (28 de noviembre de 1959). http://www.vatican.va/content/john-xxiii/es/encyclicals/documents/ hf_j-xxiii_enc_28111959_princeps.html

Juan XXIII. (1959q). Radiomensaje a los fieles de Cuba (29 de noviembre de 1959). AAS, LI(1), 909-911. http://www.vatican.va/archive/aas/documents/AAS-51-1959-ocr.pdf

Juan XXIII. (1960a). Mensaje a los fieles en ocasión de la Vigilia de Navidad de 1959. AAS, LII (2), 27-35. Texto original en italiano. http://www.vatican.va/archive/aas/documents/AAs-52-1960-ocr.pdf

Juan XXIII. (1960b) Mensaje a los participantes al VII Congreso Interamericano de Educación católica (10 de enero de 1960). AAS, LII(2), 100-103. http://www.vatican.va/archive/aas/documents/AAS-52-1960ocr.pdf

Juan XXIII. (1960c). Radiomensaje a los trabajadores en ocasión de la fiesta de 1. de mayo de 1960. AAS, LII(2), 397-400. Texto original en italiano. http://www.vatican.va/archive/aas/documents/AAs-521960-ocr.pdf

Juan XXIII. (1960d). Discurso de abertura de la II Sesión del Sínodo diocesano de Roma. AAS, LII(2), 231239. Texto original en italiano. http://www.vatican.va/archive/aas/documents/AAs-52-1960-ocr.pdf Juan XXIII. (1960e). Radiomensaje a los feligreses reunidos el en Buenos Aires por el I Congreso mariano interamericano (13 de noviembre de 1960). AAS, LII(2), 980-982. http://www.vatican.va/archive/aas/ documents/AAs-52-1960-ocr.pdf 
Juan XXIII. (196la). Carta encíclica Mater et magistra de su santidad Juan XXIII sobre el reciente desarrollo de la cuestión social a la luz de la doctrina cristiana (15 de mayo de 1961). http://www.vatican.va/content/johnxxiii/es/encyclicals/documents/hf_j-xxiii_enc_15051961_mater.html

Juan XXIII. (196lb). Alocución a los participantes al curso de estudio promovido por la Universidad Católica del Sagrado Corazón en Roma sobre "La mujer y la profesión" (6 de septiembre de 1961). AAS, LIII(3), 610-612. Texto original en italiano. http://www.vatican.va/archive/aas/documents/AAS-531961-ocr.pdf

Juan XXIII. (196lc), Constitución apostólica Humanae Salutis de nuestro santísimo señor Juan por la Divina Providencia Papa XXIII por la que se convoca el Concilio Vaticano II (25 de diciembre de 1961). http://www. vatican.va/content/john-xxiii/es/apost_constitutions/1961/documents/hf_j-xxiii_apc_19611225_humanae-salutis.html

Juan XXIII.(196ld). Alocución por el aniversario de la coronación pontificia (4 de noviembre de 1961). AAS, LIII(3), 764-769. Texto original en italiano. http://www.vatican.va/archive/aas/documents/AAS53-1961-ocr.pdf

Juan XXIII. (1962a). Alocución a los párrocos romanos (22 de febrero de 1962). AAS, LIV(4), 167-175. Texto original en italiano. http://www.vatican.va/archive/aas/documents/AAs-54-1962-ocr.pdf

Juan XXIII. (1962b). Alocución a los miembros de los Comités permanentes de los Entes católicos para la formación profesional (1. ํ de mayo). AAS, LIV (4), 455-461. Texto original en italiano. http://www. vatican.va/archive/aas/documents/AAs-54-1962-ocr.pdf

Juan XXIII. (1962c). Homilía para la fiesta de pentecostés (10 de mayo de 1962). AAS, LIV(4), 437-447. Texto original en italiano. http://www.vatican.va/archive/aas/documents/AAs-54-1962-ocr.pdf

Juan XXIII. (1962d). Alocución a la Unión de los Hombres de la Acción católica italiana (13 de mayo de 1962). AAS, LIV(4), 400-404. Texto original en italiano. http://www.vatican.va/archive/aas/documents/AAs-54-1962-ocr.pdf

Juan XXIII. (1962e). Mensaje de preparación del Concilio Vaticano II (2 de julio de 1962). AAS, LIV(4), 508 517. Texto original en italiano. http://www.vatican.va/archive/aas/documents/AAs-54-1962-ocr.pdf Juan XXIII. (1962f). Radiomensaje de ll de septiembre de 1962. AAS, LIV(4), 682. Texto original en italiano. http://www.vatican.va/archive/aas/documents/AAs-54-1962-ocr.pdf

Juan XXIII. (1962g). Alocución Gaudet Mater Ecclesia en ocasión de la solemne abertura del Concilio Ecuménico Vaticano II (ll de octubre de 1962). http://www.vatican.va/content/john-xxiii/es/speeches/1962/documents/hf_j-xxiii_spe_19621011_opening-council.html

Juan XXIII. (1962i). Alocución a los fieles reunidos a Castel Gandolfo (26 de agosto de 1962). AAS, LIV(4), 656-66l. Texto original en italiano. http://www.vatican.va/archive/aas/documents/AAs-54-1962ocr.pdf 
Juan XXIII. (1963a). Alocución al XXV Congreso Nacional del movimiento de los graduados de la Acción católica italiana (4 de enero de 1963), AAS, LV(5), 89-91. Texto original en italiano. http://www.vatican.va/archive/aas/documents/AAS-55-1963-ocr.pdf

Juan XXIII. (1963b). Homilía en ocasión de la fiesta de la purificación de la Virgen (2 de febrero de 1963), AAS, LV(5), 166-170. Texto original en italiano. http://www.vatican.va/archive/aas/documents/AAS55-1963-ocr.pdf

Juan XXIII. (1963c). Alocuciones a los peregrinos congregados en Roma por la beatificación de Elisabeth Ann Bailey (17 de marzo de 1963), AAS, LV(5), 329. Texto original en italiano. http://www.vatican.va/ archive/aas/documents/AAs-55-1963-ocr.pdf

Juan XXIII. (1963d). Carta encíclica de Su Santidad Juan XXIII Pacem in Terris sobre la paz entre todos los pueblos que ha de fundarse en la verdad, la justicia, el amor y la libertad (1l de abril de 1963). http://www.vatican.va/ content/john-xxiii/es/encyclicals/documents/hf_j-xxiii_enc_ll041963_pacem.html

Juan Pablo II. (1987). Carta encíclica Sollicitudo Rei Socialis del Sumo Pontífice Juan Pablo II al cumplirse el vigésimo aniversario de la Populorum Progressio (30 de diciembre de 1987). http://www.vatican.va/content/ john-paul-ii/es/encyclicals/documents/hf_jp-ii_enc_30121987_sollicitudo-rei-socialis.html

Juan Pablo II. (1985). Carta encíclica Evangelium Vitae del Sumo Pontifice Juan Pablo II sobre el valor y el carácter inviolable de la vida humana (25 de marzo de 1995). http://www.vatican.va/content/john-paul-ii/es/encyclicals/documents/hf_jp-ii_enc_25031995_evangelium-vitae.html

Hout, M. y Greeley, A. (1972). Religion and happiness. En P. V. Marsden (ed.), Social Trends in American Life (pp. 288-314). Princeton: PUP.

La Bella, G. (2018). Paolo vi e l'America latina. Revue d'Histoire Ecclesiastique, 113(3-4), 788-820.

Larrimore, M. (2010). Religion and the Promise of Happiness. Social Research, 77(2), 569-594.

Marianne Siegmund, J. (2019). Pope John XxIII's Mater et Magistra: The encyclical and the Notion of the Common Good. Catholic Social Science Review, 24, 57-73. Texto original en inglés.

Martín Descalzo, J. L. (s. f.). Decálogo de la serenidad de Juan XxIII. Recuperado de https://es.catholic.net/op/ articulos/18664/cat/284/decalogo-de-la-serenidad.html Æmodal

Pablo VI. (1968). Carta encíclica Humanae Vitae de Su Santidad Pablo VI sobre la regulación de la natalidad (25 de julio de 1968). http://www.vatican.va/content/paul-vi/es/encyclicals/documents/hf_p-vi_ enc_25071968_humanae-vitae.html

Pablo VI. (1975). Exhortación apostólica Gaudete in Domino de Su Santidad Pablo vi sobre la alegría cristiana (9 de mayo de 1975). http://www.vatican.va/content/paul-vi/es/apost_exhortations/documents/hf_pvi_exh_19750509_gaudete-in-domino.html

Rendina, C. (1983). I Papi. Storia e segreti. Roma: Newton Compton.

Suenens, L. J. (1964). Pope John XxiII. The Furrow, 15(7), 429-438. Texto original en inglés. 
Felicidad, empatía y solidaridad personal frente al trauma sociocultural de la pandemia en Italia

Tineo, P. (1997). Juan XXIII y el despertar de una nueva época. Anuales de Historia de la Iglesia, 6, 127-154.

Viotto, P. (1998). Tomismo come realismo critico negli scritti di Giovanni Battista Montini/Paolo VI. Rivista di Filosofía Neo-scolastica, 90(1-2), 232-245.

\section{Bibliografía}

\section{Artículos de revistas}

Almeida, J. A. (2012). Juan XxiII, el Papa del Concilio. Revista Latinoamericana de Teología, 29(85), 9-36.

Bianchi, E. C. (1970). John XXIII, Vatican II and American Catholicism. The Annals of the American Academy of Political and Social Science, 387(1), 30-40.

Carlotti, P. (2013). Il magistero dopo la Pacem in Terris. Rivista di Teologia Morale, 179, 333-340.

De Céspedes, C. M. (2001). Palabras expresadas a Luis Armando Bianco, embajador cubano en el Vaticano en medio de la crisis de octubre de 1962. Palabra Nueva, 98.

Chenaux, P. (2019). John XXIII. An unexpected Pope. Revue d'Histoire Ecclesiastique, 114(3-4), 1009-1020.

Echeverri, A. (2014). "Al menos, un poco de aire fresco. Contribución a una relectura de la paz y la libertad religiosa desde la encíclica Pacem in terris”. Franciscanum, 162(57), 133-159.

Galavotti, E. y Ruggieri, G. (2009). I diari di Giovanni XXIII. Concilium, 45(5), 974-1006.

García Cardiñanos, F. (2013). Releyendo Pacem in Terris. Corintios XIII, 148, 65-79.

Guitián, G. (2014). Juan XXIII y la encíclica Pacem in Terris: la relación entre bien común y subsidiaridad. Scripta Theologica, 64(2), 381-399.

Hubert Robinet, A. M. (2012). Juan XXIII y el inicio del Concilio Vaticano II. Cuadernos de Teología-Universidad Católica del Norte, 4(2), 218-241.

Melloni, A. (1992). "Questa festiva ricorrenza”. La preparazione del discorso di Giovanni XXIII di convocazione del Vaticano II. Rivista di Storia e Letteratura Religiosa, 28(3), 607-643.

Piquer, J. (1984). Juan XXIII y Kruschev. Historia y vida, 17(193), 58-69.

Regoli, R. (2012). Pastor et auctor. Gli scritti privati di Angelo Giuseppe Roncalli-Giovanni XXIII. Gregorianum, 93(4), 831-856.

Sale, G. (2013). Il cincinquantesimo aniversario della Pacem In Terris. La Civiltá cattolica, 164, 9-22.

\section{Monografías}

Alberigo, G. (1984). Fede, tradizione, profezia: Studi su Giovanni xxIII e sul Vaticano II. Brescia: Paideia.

Alberigo, G. (2000). Papa Giovanni 1881-1963. Bolonia: EDB.

Balducci, E. (2000). Giovanni XXIII. Casale Monferrato: Piemme.

Benigni, M. y Zanchi, G. (2000). Juan XxIII. Madrid: San Pablo. 
Bolis, E. (2014). Giovanni XxIII y Paulo VI. I Papi del Vaticano II. Atti del Convegno internazionale di studio (Bergamo 12-13 aprile 2013). Roma: Studium.

Chenaux, Ph. (2013). Giovanni XxIII e Paolo VI. I due Papi del Concilio. Roma: LUP.

Copello Faccini, A. y Bonnet, M. P. (2003). Kennedy y Juan XxIII: Constructores de paz. Bogotá: UBJTL.

Cousins, N. (1972). The Improbable Triumvirate: John Fitzgerald Kennedy, Pope John, Nikita Khrushchev. Nueva York: Norton.

Doria, P. (2016). Storia del Concilio Vaticano II: da Giovanni XxIII a Paolo VI (1959-1965). Todi: Tau Editrice.

Festini, F. (2011). La tela di Giovanni. Papa Roncalli e la crisi dei missili a Cuba. Roma: Sisip.

Fondazione per le scienza religiose Giovanni XXIII. (2003). Un cristiano sul trono di Pietro. Studi storici su Papa Giovanni XxIII. Gorle: Servitium.

Franco, M. (2005). Imperi paralleli. Vaticano e Stati Uniti: due secoli di alleanze e conflitto (1788-2005). Milán: Mondadori.

González Balado, J. L. (2005). Vida de JuanxxIII. Madrid: San Pablo.

Lovatti, M. (2019). Giovanni XxIII, Paolo vi y las ACLI. Brescia: Morcelliana.

Maalouf, J. (2009). Escritos esenciales de Juan XXIII. España: Sal Terrae.

Malnati, E. (2011). Mater et magistra di Giovanni XXIII 50 anni dopo. Roma: LEV.

Melloni, A. (2000). Il giornale dell'anima di Giovanni XxIII. Milán: Jaca Book.

Melloni, A. (2009). Papa Giovanni. Un cristiano e il suo concilio. Turín: Einaudi.

Melloni, A. (2010). Pacem in Terris. Storia dell'ultima encíclica di Papa Giovanni. Bari: Laterza.

Merlo, G. G. (2009). L'ora che il mondo sta attraversando. Giovanni xxIII di fronte alla storia. Roma: Edizioni di storia e letteratura.

Neuevecelle, J. (1984). Pio XII y Juan XXIII. En A. Fliche y V. Martin (eds.). Historia de la Iglesia de los orígenes a nuestros días, vol. 27.2. Valencia: Edicep.

Pérez Sánchez, A. (trad.) (2008). Diario del alma de Juan XxIII. España: San Pablo.

Riccardi, A. (1992). Il Vaticano e Mosca. Roma-Bari: Laterza

Riccardi, A. (2014). L'uomo dell'incontro. Angelo Roncalli e la política internazionale. Cinisello Balsamo: San Paolo. 



\title{
5 \\ Persona, convivencia y felicidad. Condiciones ético-políticas y educativas para la construcción de la felicidad*
}

\author{
VÍctor MARTIN-FIORINO** \\ DARWIN MUÑOZ-BUITRAGO***
}

\section{Resumen}

Este trabajo aborda el tema de la felicidad, entendida como realización progresiva de un proyecto de vida valioso, desde las condiciones que dificultan su construcción en contextos de sociedades marcadas por el cansancio, el miedo y la despersonalización. La felicidad es abordada en sus múltiples dimensiones e interacciones, con especial referencia a la dimensión espiritual y la apertura a la trascendencia. Los obstáculos para la construcción de felicidad son vistos

\footnotetext{
* El presente capítulo es un producto de investigación del proyecto de investigación Religión y Sociedad del Grupo Philosophia Personae del Departamento de Humanidades de la Universidad Católica de Colombia.

** Docente e investigador de la Universidad Católica de Colombia. Director del grupo de investigación Philosophia Personae. Doctor en Filosofía. Con estudios posdoctorales en Ética Aplicada. Magíster en Filosofía. Doctor Honoris Causa. Profesor emérito de la Universidad del Zulia, Venezuela. Profesor distinguido de la Universidad Nacional de Cuyo, Argentina. Investigador sénior de la Universidad de Salerno, Italia. Investigador sénior del Ministerio de Ciencia, Tecnología e Innovación. Premio Internacional Miguel Martínez Miguélez a la Excelencia en Investigación. Par académico de Colciencias. Licenciado en Filosofía. Profesor de enseñanza superior en filosofía. vrmartin@ucatolica.edu.co https://orcid.org/0000-0003-4057-7974

***Coordinadorde Docencia delDepartamentode Humanidades dela Universidad Católicade Colombia. Máster Internazionale in Scienze Politiche per la pace e l'integrazione dei popoli, Università Degli Studi di Salerno, Italia. Maestría en Ciencia Política, Universidad Católica de Colombia. Licenciado en Teología de la Pontificia Universidad Javeriana. Baccalaureum in Theologia de la Pontificia Universidad Javeriana. Estudios de Filosofía en la Universidad San Buenaventura de Bogotá. Condecorado con la Orden al Mérito Académico Javeriano de la Pontificia Universidad Javeriana (2006). Premio a la Excelencia Docente, 2008, 2011, 2013, 2014, 2017 y 2019. Premio a la Excelencia Tomasina, 2014. Investigador y par académico reconocido por Colciencias. damunoz@ucatolica.edu.co https://orcid.org/0000-0002-3193-6034
} 
principalmente desde las condiciones de conflictividad y violencia y su tratamiento en las mediaciones educativas orientadas al aprendizaje cooperativo, el ejercicio del diálogo, la resolución de conflictos, la cultura de paz y la construcción de convivencia. El trabajo fundamenta la importancia de transformaciones educativas fundadas en la antropología personalista y propone un abordaje que integra, en una interdependencia constructiva, la felicidad de la persona, la construcción de comunidad y el cuidado de la casa común.

Palabras clave: persona, convivencia, felicidad, cultura de paz, sostenibilidad.

\section{Abstract}

This work addresses the issue of happiness, understood as the progressive realization of a valuable life project, from the conditions that hinder its construction in contexts of societies marked by fatigue, fear and depersonalization. Happiness is addressed in its multiple dimensions and interactions, with special reference to the spiritual dimension and openness to transcendence. The obstacles to the construction of happiness are seen mainly from the conditions of conflict and violence and their treatment in educational mediations oriented to cooperative learning, the exercise of dialogue, the resolution of conflicts, the culture of peace and the construction of coexistence. The work bases the importance of educational transformations based on personalist anthropology and proposes an approach that integrates, in a constructive interdependence, the happiness of the person, the construction of community and the care of the common home.

Keywords: person, coexistence, happiness, culture of peace, sustainability.

\section{Introducción}

El propósito de este capítulo es aportar a la comprensión del papel que desempeñan las condiciones ético-políticas y educativas en la posibilidad de las personas de pensar y realizar de manera efectiva un proyecto de vida feliz, entendido como realización de la persona en el conjunto de las dimensiones de su vida y a lo largo de todo su desarrollo. Para ello se analiza el marco de contextos socioeconómicos 
existentes en relación con los factores de incidencia en los proyectos de vida, considerados en sus dimensiones personales, comunitarias y trascendentes.

Con apoyo en el pensamiento filosófico y como necesaria labor de contextualización de la reflexión sobre la felicidad en las sociedades contemporáneas, este estudio plantea una articulación entre un momento clásico del tema, centrado en Aristóteles, y un momento contemporáneo, desde la antropología personalista. Se pone un interés especial en la relación entre la resolución de conflictos, la construcción de convivencia y la cultura de paz, como plataforma para la felicidad de las personas desde la cual desbloquear y transformar situaciones de incompatibilidad que la obstaculizan. El propósito es incidir en los espacios educativos y políticos, donde se juega la comprensión y la gestión de las formas de interdependencia en cuyo marco las personas buscan ser felices, resolver sus conflictos y armonizar la búsqueda del bien personal con el bien de todos.

El problema a cuya dilucidación se busca aportar es el que se deriva de reducir la felicidad al éxito individual basado en la riqueza, el poder o el prestigio, lo que produce como consecuencia que se considere a la educación como una preparación, principalmente técnica, para el desarrollo de la competitividad, la productividad y los resultados, sin atribuir importancia significativa a la formación humana para la compasión, la solidaridad y la cooperación.

Los objetivos de este trabajo apuntan a proporcionar herramientas para identificar, valorar y gestionar los condicionamientos que obstaculizan el proceso de realización de la felicidad personal y de construcción de comunidad. Para revisar la fundamentación de sus contenidos y sentar las bases para la formulación de estrategias educativas orientadoras, se expone el valor de aprender a resolver los conflictos que se derivan de tales condicionamientos y construir cultura de paz como base de la felicidad.

\section{Metodología}

Desde el punto de vista metodológico, para alcanzar el cumplimiento de los objetivos, el trabajo investigativo se ha centrado en el interés de comprender los 
elementos ético-valorativos referidos a las condiciones necesarias para la felicidad, para lo cual se ha buscado realizar una interpretación crítica de los principales antecedentes del tema en textos de autores reconocidos. Para ello, el itinerario metodológico ha sido el de una investigación cualitativa de carácter documental con enfoque hermenéutico, según los criterios establecidos por Hernández Sampieri (2018).

Desde esta base metodológica y mediante una revisión de los antecedentes y contribuciones previas, el trabajo ha buscado construir una interpretación crítica del tema de la felicidad, en relación con las condiciones para su logro, con mayor atención a las aplicaciones de los resultados obtenidos en las áreas de la ética, la política y la educación, con el fin de realizar aportes a la transformación de aquellos aspectos que se relacionen con el tema tratado.

\section{Resultados}

Los resultados de la investigación han permitido establecer las grandes áreas en las que se despliegan las principales contribuciones del tema estudiado en los ámbitos de la educación, la ética y la política, a partir de los cuales ha sido posible establecer las principales condiciones para la construcción de la felicidad. Estas áreas se relacionan con una visión integradora de las dimensiones de la persona, el espacio de la política y su relación con la construcción de la felicidad de la persona en cuanto ciudadano, la relación entre la felicidad y los límites de la condición humana, el paso de la sociedad política a la construcción de comunidad de personas, las condiciones de las sociedades del riesgo, la necesidad de gestionar los conflictos sin violencia y construir la paz como condición para la felicidad y la importancia del aporte de la antropología personalista.

\section{Ética, felicidad e integralidad de la persona}

La aspiración permanente de los seres humanos a la felicidad se expresa, de un modo progresivo y no exento de dificultades, como proceso de autoconocimiento, autovaloración y autoafirmación de la persona, en convivencia y en apertura 
a la trascendencia. Para comprender y valorar dicho proceso es necesario revisar, especialmente desde los espacios educativos y teniendo en cuenta las orientaciones ético-políticas, el modo en que las personas pueden situarse de modo crítico frente a los principales factores condicionantes, que obran sobre: a) el pensamiento, dificultando el acceso al conocimiento necesario para poder pensar las metas del proyecto de vida; b) el bienestar económico, obstaculizando alcanzar una posición desde la cual se pueda decidir y realizar dicho proyecto; c) desvalorizando los contenidos éticos y espirituales, al absorber la vida de la persona en la productividad y la materialidad.

El estudio crítico de los condicionamientos ético-políticos para alcanzar la felicidad, entendida esta como camino de progresiva realización humana, toma en consideración todas las dimensiones de la persona, desde la seguridad física de la corporalidad hasta la apertura al sentido en la espiritualidad mediante un enfoque integrador. Este enfoque se justifica debido a que por mucho tiempo la visión del ser humano estuvo marcada por diferentes formas de dualismos, desde la contraposición entre forma, materia, alma, cuerpo, res cogitans, res extensa, hasta influir hoy en día en la relación entre lo virtual y lo presencial, la visión del ser humano como un holograma y la felicidad como el modo en que se asume esa representación

El fundamento de la visión integradora es el concepto de persona, cuyo desarrollo tiene una larga historia que va desde Boecio (siglos V-VI) o Ricardo de San Víctor (siglo XII) hasta el personalismo contemporáneo. La evolución de este concepto ha mostrado al ser humano en toda su complejidad y riqueza, desplegada en la multiplicidad e interacción de sus diferentes dimensiones. Esta evolución ha contribuido a enriquecer el debate de la educación de la persona, con argumentos aportados por la ética, la política y el derecho (Culleton, 2010) en relación con lo propio del individuo y lo común (comunidad).

Las diferentes dimensiones de la felicidad que se abordan en este trabajo son expuestas desde las exigencias que el desarrollo de un proyecto de vida valioso plantea a la ética, la política y la educación, sin quedar reducidas a estados de la 
mente. En tal sentido, su campo de reflexión y de aplicación es diverso al de la psicología positiva (Seligman, 2011) y de las orientaciones que conciben la felicidad como un estado de la mente vinculado al placer o al fluir o bien que buscan medirla en relación con índices macroeconómicos o de "inversión prosocial".

En consonancia con la realidad de la persona que se despliega como proceso de múltiples interacciones, la felicidad ha sido vista inicialmente en relación con el cuidado del cuerpo y la salud en cuanto búsqueda de equilibrio, aspecto ya planteado por Aristóteles como condición para ser feliz. En la misma dirección, la afectividad como factor equilibrante sobre la base del relacionamiento positivo con los demás, se ha planteado como elemento que contribuye de modo importante a la felicidad. En la filosofía griega, el papel de estas dos dimensiones como factores de armonización y, en consecuencia, posibilitantes de felicidad; expuesto por Aristóteles, tanto en la Ética a Nicómaco como en la Retórica, ha sido estudiado de modo fecundo por Martha Nussbaum en su obra La terapia del deseo (2001).

En cuanto a la sensibilidad, tercera de las dimensiones de la persona en la que se construye la felicidad, en ella se abre la percepción directa de lo humano sufriente o exultante, así como a la fuerza de la experiencia del arte y la búsqueda de la armonía en la forma. En cuarto lugar, en la racionalidad y mediante el desarrollo de la conciencia, se produce la integración del orden intelectual (ordo intelletii) y el orden del corazón (ordo cordis; "razón cordial") (Cortina, 2011), que capacita a la persona para discernir entre lo que daña y lo que es bueno - para sí, para el otro y para lo común- y obrar en consecuencia.

De modo integrador, la espiritualidad se constituye como espacio para el descubrimiento del sentido y apertura a la trascendencia y actuando de modo articulador con respecto a las demás dimensiones, permite la gestión de la dialéctica entre la resignación y la esperanza que incide de modo determinante en la felicidad. La espiritualidad es decisiva para que, al encontrarse la persona frente a los límites de la razón y de lo comprensible, no sobrevengan la resignación al absurdo y la desesperanza, sino que, desde la esperanza, sea capaz de buscar sentido a la propia vida (Rosas-Jiménez, 2016). 
La construcción de la felicidad remite también a las dimensiones de supervivencia, coexistencia y convivencia, como fases de la trama de interdependencia constructiva que caracteriza la vida humana (Martin-Fiorino, 2017). Estas fases se comprenden en paralelo con las ideas de subsistencia básica, vida como complementación y vida buena como elección. En tal sentido: a) la supervivencia, como nivel básico, se procura atendiendo a la idea de necesidad (mínimos imprescindibles); b) la coexistencia se construye desde la idea de conveniencia (leyes, derechos, deberes); c) la convivencia se logra activando la idea de libertad, en entornos de cuidado mutuo, colaboración y solidaridad. Solo alcanzando este último nivel se puede aspirar a ser feliz.

Desde las dimensiones de la persona es necesario mirar la posibilidad de la felicidad más allá de una cultura y una ética de la supervivencia (Martin-Fiorino, 2014; 2018), que se autojustifican en una visión reductiva de la naturaleza humana. A partir del aseguramiento de la supervivencia, la educación y la política son el camino para la aparición de la dimensión del afecto, productora de seguridad afectiva, y de la conciencia para descubrir el lugar existencial de valores compartidos. La fuente de la seguridad afectiva y existencial está en el "nosotros" de la convivencia (Martin-Fiorino y Holguín, 2018) — representado por la humanidad, la comunidad, la familia - que antecede y sucede al yo, constituyéndolo en acto como realidad relacional.

El eje de sentido que permite comprender la continuidad del proceso de construir la felicidad personal está en la percepción de ese nosotros que le confiere sentido a la supervivencia (descubrirse existiendo gracias a otros) que abre la comprensión del hecho de estar vivo junto a otros como un don (fruto del amor), como el resultado de un esfuerzo compartido con otros (trabajo), como un deber de servicio a los otros (compasión) y una responsabilidad solidaria (para con otros) a través del mutuo cuidado y del hacerse cargo de sí, del otro y de lo común. 


\section{La política: espacio para la felicidad del ciudadano}

Una lectura contemporánea del tema de la felicidad en el pensamiento de Aristóteles (De Luise y Farinetti, 2014) muestra que la felicidad estaba estrechamente vinculada a los valores compartidos en el sistema de convivencia establecido - la polis - y al ejercicio de la ciudadanía, que garantizaba a quienes tenían acceso a ella la posibilidad de ser felices a lo largo de la vida (Aristóteles, 2001). Ello establece ya un nexo entre felicidad personal, convivencia y el largo plazo de una vida, aunque es claro que, en el marco de la sociedad esclavista dominante en esa época, solo una minoría - los varones libres - podía acceder a la condición de ciudadanos y, en consecuencia, tener la posibilidad de ser felices.

Tener el tiempo y la educación necesaria para pensar, contar con ingresos que aseguren la vida y armonizarse con los valores de la cultura eran condiciones para buscar la felicidad. Esta, según Aristóteles (Ética a Nicómaco, III), es el bien que los seres humanos buscan como el fin principal al cual se ordena la vida, el cual, más allá de la dificultad de precisar su contenido, se va logrando teóricamente a través de la educación y prácticamente en la política.

El ser humano, a diferencia de los dioses o las bestias, necesita de la polis para realizar, a través del ejercicio de la ciudadanía, su proyecto de vida buena como contenido efectivo de la felicidad. Es en el marco de la polis donde es posible, a través de la palabra (logos), la deliberación (boúlesis) y la ley (nomos), desmontar los conflictos que obstaculizan la vida buena y el logro de la felicidad, que se obtiene a través de la progresiva construcción de la justicia (diké).

La polis como espacio para la felicidad estaba basada en la articulación de tres conceptos que orientan la conducta de los seres humanos: logos, la conducta pensada, la guía racional, reflexiva de la acción; pathos, la conducta adoptada frente a lo que nos afecta, el modo sensato de reaccionar ante lo que nos pasa y que no controlamos; ethos, la conducta esperada, el obrar bien como fundamento del convivir (Martin-Fiorino, 2000). 
Estos conceptos, que formaban parte de la Paideia como conjunto de ideales de la cultura griega (Jaeger, 1990), nutrían la educación del "hombre de la cultura" (pepaidéumonos: hombre cultivado) del que habla Aristóteles (2001), base previa y necesaria para que puedan existir el hombre de pensamiento (philosophós) y el de la política (polités), este último entendido como el hombre sabio y prudente (fronimós) y también respetuoso de la ley (spoudaios) (Aristóteles, Política, III).

Se trata del "hombre total" del que habla Aristóteles en la Ética a Nicómaco y en la Política, hombre de los valores, de la reflexión y de la convivencia. Desde esas bases se construyó una cultura política según la cual para la realización de la felicidad es necesaria la organización racional de la convivencia entre los ciudadanos en vistas al cumplimiento del valor de la justicia como principio rector del ordenamiento armónico de la vida en común.

La educación es la encargada de formar para la política, es decir, para la gestión del único marco posible para la felicidad centrado en la justicia como virtud política (De Luise y Farinetti, 2014). En Aristóteles, la educación, como espacio para los valores, y la política, en el sentido de saber prudente y justo, son las bases para construir convivencia (polis) como base de la felicidad entendida como la convergencia entre el bien personal y el bien común.

\section{¿Ser felices como humanos o como dioses?}

Contextualizando el pensamiento de Aristóteles cabe destacar la importancia del planteamiento acerca de cómo queremos ser felices: "como hombres" o "como dioses" (De Luise y Farinetti, 2014). A diferencia de su maestro Platón, la noción de "felicidad posible" que sostiene Aristóteles, el "ser felices en los límites", está ligado a cumplir con la obra propia del hombre (ergon anthropinon) (Ética a Nicómaco I, 6), gestación de lo humano en las mediaciones de su existencia que permite considerar la felicidad como algo que se evalúa como proceso a lo largo de toda la vida.

Esta felicidad posible es contraria a la pretensión de ser felices "como los dioses", entendida, ya en Aristóteles, como pretensión de autosuficiencia que no reco- 
noce la necesidad ni el valor de convivir. Se desentiende de la interdependencia constructiva inherente a la vida, puede generar indiferencia e insensibilidad y consecuentemente insolidaridad. A lo sumo, lamentar las desigualdades y, en definitiva, promueve solo la realización individual y competitiva que reposa en el poder (del conocimiento, de la posición).

Traducida a términos contemporáneos, ser felices "como los dioses" tiene también relación con la pretensión de "construir lo humano" en la tecnología o el laboratorio, "desmesura" que plantea sustituir la naturaleza limitada del ser humano por un constructo tecnológico, liberado de limitaciones y "reparable" de modo indefinido. Subyace en esta posición una pretensión, si no de inmortalidad, al menos de a-mortalidad, a partir de un endiosamiento del poder de la tecnología, colocada más allá de todo límite, incluso moral.

El tema de la diferencia con los dioses pudiera evocar algunas provocativas propuestas sobre la transición "de animales a dioses" o sobre el "Homo Deus" como la de Yuval Harari (2017), de la que, sin embargo, es necesario tomar clara distancia. Dicha interpretación, en el marco de una ideología biológica y naturalista, no deja espacio, más allá de los algoritmos (Lafferrière, 2017), para pensar a la persona en un proceso de humanización, con lo que se desvaloriza todo papel de la ética, la espiritualidad o la religión por considerarlas invenciones humanas.

Por otra parte, y desde otra perspectiva, pretender ser feliz como los dioses excluye cualquier papel de la negociación como forma pacífica de resolución de conflictos. En la práctica, esa pretensión conduce a evadir "el trabajo" —necesidad, conveniencia o deber- de tener que negociar los conflictos, lo que la sitúa en contradicción con el avance ético de la humanidad. Como los dioses no están llamados a negociar ni justificar sus acciones, esta visión termina por justificar el abordaje violento de los conflictos como parte de una especie de "lógica de las cosas": imponer la voluntad cuando se tiene el poder o aceptar la sumisión cuando no se lo tiene.

Entre los griegos, este tipo de felicidad "como los dioses" no exigía tampoco respetar la justicia, que en la polis estaba reservada a los iguales (ciudadanos), no a 
los dioses. La justicia es solo humana y, según Aristóteles (2001), está presidida por la "justicia política" entendida como lo justo en su realización concreta en la polis, que se cumple "entre individuos libres e iguales que participan en una comunidad de vida para hacer posible la autarquía” (Ética a Nicómaco, v, 1134).

Precisamente la autarquía, a cuya construcción apunta la justicia política, es la que asegura una de las bases de la felicidad de los ciudadanos. Sobre ello afirmó Aristóteles que "hay que ser una bestia o un dios para no necesitar vivir en la polis" y, con ello, poder ser feliz. La felicidad posible, realizable únicamente en la polis, requiere, a diferencia de lo que ocurre con los dioses, deliberación, convivencia y justicia como capacidades y mediaciones propiamente humanas.

\section{Felicidad: de la polis de ciudadanos a la comunidad de personas}

En relación con la felicidad, en la actualidad se ha hecho más claro que sus protagonistas son seres humanos concretos, no el Estado que decrete la felicidad ni el individuo aislado que la defienda en abstracto. Personas cuyas búsquedas se cumplen en el marco de sociedades de alta conflictividad, marcadas por importantes niveles de desigualdad e inequidad que dificultan la convivencia y condicionan la coexistencia — en muchos casos vistas solo como una obligación legal-, sociedades que con frecuencia hacen crisis ante situaciones en las que está en juego la supervivencia.

Desde la perspectiva de las ideologías centradas en el individualismo o el colectivismo, experiencias frecuentes en las sociedades contemporáneas que se apartaron de la democracia, las exigencias de supervivencia han empujado a plantear políticamente e intentar justificar éticamente formas degradadas de felicidad, ubicadas en los extremos del refugio en el aislamiento o la disolución en la masificación. Absolutizando el papel del individuo o el papel omnipresente del Estado, estas ideologías fracturan tanto la constitutiva identidad relacional de la persona (Marcos y Pérez-Marcos, 2018) como también la libertad de elegir el camino de su realización personal. 
Entre los obstáculos a la construcción de felicidad que, sumados a los que han existido históricamente, se acentúan en la actualidad, entre otros, los altos niveles de dependencia de factores económicos y políticos globales, la presión productiva o de obediencia al Estado, las exigencias de eficacia, los controles de la información, la desaparición del tiempo personal en favor de las urgencias productivas, la obsesión por la imagen y la visibilidad y el vaciamiento de sentido provocado por la desvalorización de la dimensión espiritual.

El nivel de tales obstáculos se visualiza al considerar el proceso de construcción de felicidad que requiere, en primer término, acceso a la educación y al conocimiento considerados como elementos necesarios para pensar y decidir un proyecto de vida valioso (Martínez, 2019). Entendiendo la educación como un proceso a lo largo de toda la vida, se van abriendo en cada etapa, con sus características, potencialidades y limitaciones, valiosos espacios de realización que contribuyen a dar sentido de plenitud a la vida de la persona.

La educación se constituye progresivamente en plataforma para la felicidad en la medida en que ella es capaz de formar para ejercer de modo real, al mismo tiempo reflexivo, prudente y eficaz, la capacidad de elegir, la primera de las capacidades humanas según Amartya Sen (Sen y Nussbaum, 2001). De igual manera, el nivel educativo que alcance la persona hace posible que pueda participar de manera más plena, en condiciones de mayor autonomía y capacidad crítica, en la vida política y el acceso a niveles decisorios para la realización efectiva del derecho al proyecto de vida valioso (Caldera Ynfante, 2018).

\section{Replantear la felicidad desde el riesgo, el poder y las capacidades}

A lo largo de la historia de las sociedades occidentales los factores condicionantes tanto de la vida real de las personas como de las posibilidades de su felicidad han ido transformándose, pero permaneciendo, en la mayoría de los casos, vinculadas al acceso a espacios y oportunidades que solo se plantean en la vida en común. En las sociedades contemporáneas ello se expresa en el aumento de 
imperiosas exigencias de justicia, orientadas a garantizar la participación política, a impulsar la conformación de acuerdos y a trabajar por la erradicación de cualquier tipo de violencia.

En este trabajo se deja solamente señalado el interés de considerar críticamente, en futuras investigaciones, el tema de la felicidad en perspectivas como la psicología positiva (Seligman, 2011), los estudios de la conducta centrados en el cerebro y la mente (Burnett, 2018) o los trabajos sobre la felicidad en perspectiva intercultural (Montoya Vázquez, 2013). El presente estudio delimita su abordaje al terreno del pensamiento filosófico práctico, donde la felicidad aparece en intrínseca asociación con la construcción de comunidad política y se abre a la posibilidad de construir una comunidad ética. Su fase inicial consiste, según Adela Cortina (2017), en la superación de las diversas formas de rechazos, fobias y exclusiones mediante la práctica de nuevas formas de ciudadanía articuladas en torno al papel central de la persona, la compasión y la solidaridad.

En sociedades permanentemente en situación de crisis, la cuestión de las condiciones para pensar, elegir y realizar en la práctica una vida digna y valiosa, es decir, feliz, cobra especial relevancia. Ello puede representar la oportunidad de recuperar capacidad de futuro, entendida como capacidad de construir en la práctica, en condiciones de riesgo y fragilidad, un proyecto de realización personal, convivencia social y sostenibilidad ambiental. Un estudio de Roberta Paltrinieri (2019) resume estos aspectos en el concepto de "felicidad responsable".

La experiencia de las sociedades del riesgo (Beck, 2007) es el horizonte desde el que se plantea, como desafío, la posibilidad de construir una visión de la vida como proyecto de largo plazo, la práctica del cuidado humano y la exigencia imperativa de la sostenibilidad. Se trata de sociedades altamente dependientes de la tecnología y carentes de bases humanistas y espirituales (Palacio Vargas, 2015); en estos contextos, al agudizarse las situaciones de riesgo global —de salud, crisis económica, guerras - entran en crisis las creencias en la seguridad ofrecidas por la tecnociencia, las ideologías o los sistemas económicos. 
Se deriva de ello la necesidad de replantear, especialmente en la educación, las preguntas sobre la seguridad como factor importante para el proyecto de vida de las personas. Ello implica desarrollar y contextualizar el concepto de seguridad humana, especialmente en sus bases éticas y consensuales, como una de las bases de la felicidad. En 2012, la ONU elaboró una iniciativa con orientaciones valiosas sobre el tema, que luego fue contextualizada en estrategias educativas por la Unesco. De igual modo, el papa Francisco ha formulado orientaciones valiosas sobre la relación entre seguridad, espiritualidad y sostenibilidad en la Encíclica Laudato Si'.

Seguridad y poder han tenido desde antiguo una estrecha relación. En el siglo XX, el surgimiento de la biopolítica (Foucault, 1978) ha mostrado los múltiples efectos negativos del uso del poder para el dominio de la vida (Foucault, 1978), principalmente por medio del control de la salud, la alimentación y la seguridad. Ello puso claramente de manifiesto los efectos deshumanizadores de las sociedades del miedo (Bude, 2018), marcadas por la inseguridad y el ejercicio del poder sobre la vida concreta de las personas.

Por diversos factores vinculados, entre otros, a un mayor acceso a la información, las últimas décadas han registrado el avance de una demanda ética global como aspiración a poder organizar la vida de un modo más humano y alcanzar mayores niveles de bienestar. De ello se han derivado, más allá de las expectativas retóricas generadas en el ámbito de las ideologías, amplios cuestionamientos de fondo acerca de la posibilidad real de construir felicidad en el marco de sociedades de supervivencia (Martin-Fiorino, 2018), de la decepción (Bauman, 2016) o del cansancio (Han, 2019).

Bajo la presión de los grandes acontecimientos que marcaron el último tercio del siglo Xx como el inicio de un nuevo "siglo político" (Sapir, 2008), en las primeras décadas del siglo XXI se ha planteado la necesidad de mirar críticamente las consecuencias de la globalización y, en su lugar, reconocer, valorar y reconstruir la interdependencia constructiva como concepto, experiencia y paradigma de la vida (Punset, 2005). Este concepto, tomado de la biología y que se refiere al 
principio colaborativo que dio lugar al comienzo de la vida, permite comprender cuánto se necesitan los seres humanos entre sí y en qué medida necesitan del cuidado mutuo.

\section{El "nosotros" de la felicidad}

Construido durante mucho tiempo desde relaciones de dependencia (económica, política, cultural), el problema de cómo vivir en sociedad irrumpe con fuerza en el siglo XXI como demanda de convivencia. Ello ha dado lugar a un importante esfuerzo teórico-crítico de fundamentación, un ejercicio ético de valoración y, sobre todo, un conjunto de políticas para posibilitar su práctica efectiva bajo participación y control ciudadano.

Principalmente por la presión derivada de la existencia de amplios espacios donde las personas solo pueden aspirar a la supervivencia, el problema de la convivencia interpela al actual debate político, cultural y educativo como exigencia crítica que abarca, entre otros, la necesidad de impulsar la cultura del "nosotros" a partir de acuerdos sobre derechos, deberes y condiciones de mayor bienestar, en especial, para los más vulnerables.

Desde la revalorización del nosotros como situación vital y a partir de la ampliación semántica del "vivir-con", el concepto de convivencia tiene ya un importante, aunque relativamente reciente, recorrido de resignificación y de referencia a prácticas específicas (Jares, 2001; Marina, 2006). El énfasis está puesto especialmente en los aspectos educativos y entre los elementos decisivos se encuentran la resolución pacífica de conflictos, la construcción de condiciones reales de paz, la protección y seguridad de la vida, la construcción de cultura de paz y el mejoramiento de los niveles de desarrollo humano.

La educación es el espacio real y la sede para la transformación de la mente con vistas a la valoración de la convivencia negociada por encima de la confrontación (Unesco, 2015) e impulsando, por medio de iniciativas educativas, que los actores sociales puedan conocerse, comparar y cooperar en la tarea de educar en lógicas y prácticas de cuidado mutuo y cooperación, desmontando las lógicas centradas en 
el poder y la competitividad predominantes en la actual globalización financiera y en los proyectos ideológicos hegemónicos.

Aunque la educación no se ha transformado al mismo ritmo de los cambios sociales ocurridos desde el último tercio del siglo, en sus espacios, en especial en la educación superior, existen ya avances significativos orientados a una educación que pueda confrontar los principales escenarios de deshumanización (Orsalc, 2019) como obstáculos para la libre elección y la realización del proyecto de vida valiosa asumido como felicidad.

A la supervivencia económica entendida como vida en el límite (de grado mínimo) se suma actualmente la supervivencia digital como nueva forma de analfabetismo y degradación de las posibilidades para actualizar el potencial humano de la persona. Como nuevas formas de discriminación y rechazo (desde la aporofobia como rechazo al pobre a la exclusión informática), estas prácticas rompen los lazos del tejido social humano necesario para construir comunidad (Téllez, 2010). En tal sentido, es claro que el "nosotros" personalizado y personalizador que sirve de plataforma para la felicidad no puede alcanzarse en entornos de pobreza, discriminación o indiferencia.

\section{Del conflicto a la negociación: felicidad y paz}

De acuerdo con numerosos estudios (Galtung, 2003; Fisas, 2007), las diferentes formas de deshumanización y de negación del derecho al proyecto de vida valioso que le da contenido a la felicidad personal tienen como base común el irrespeto, la intolerancia y las formas explícitas o implícitas de violencia. De estas se generan lógicas de dominio y prácticas que degradan la vida — de personas, comunidades, naciones y entornos naturales - para favorecer intereses de hegemonía económica o política, afectando posibilidades básicas para la construcción de felicidad.

Desde una fundamentación en la antropología personalista, la educación encuentra un importante espacio para el desarrollo de áreas como el cuidado del lenguaje (orientado a la convivencia), de la mente y del espíritu, que a su vez articulan y 
dan un sentido más profundo, según se ha expresado antes, al cuidado del cuerpo, de las relaciones y del entorno. Ello muestra el importante papel de las éticas del cuidado y la compasión en la educación (Mesa, 2005) para el desarrollo de la vida feliz de las personas.

Como parte del cuidado del lenguaje, la construcción de convivencia exige el claro rechazo del uso de la violencia verbal como herramienta política y, paralelamente, como modo de justificación de dicha violencia mediante el recurso a desvalorizaciones étnicas, culturales o religiosas. Unida a formas de violencia simbólica, la violencia verbal desemboca casi inevitablemente en violencia física, lo que atenta gravemente contra la dignidad de la persona, destruye la posibilidad de la paz e imposibilita alcanzar la felicidad.

No cabe duda de que los debates contemporáneos acerca del contenido de la felicidad se desarrollan en contextos marcados por condiciones de violencia de diversos niveles y múltiples formas, como expresiones de exclusión, desigualdad y discriminación. Por otra parte, las situaciones de persecución, enfrentamiento armado, racismos e intolerancias generan desplazamientos y migraciones forzadas de carácter masivo que representan formas negadoras de la posibilidad de elegir la felicidad, como la desciudadanía (Kliksberg, 2001) o la apatridia (Ávila Hernández et al., 2020) y sus consecuencias que provocan mayor desamparo en poblaciones especialmente vulnerables.

La reflexión y el discurso acerca de la felicidad, en particular en los ámbitos educativos, se confrontan al hecho de que las situaciones negativas descritas han acompañado a los seres humanos a lo largo de gran parte de su historia y han sido consideradas inevitables por teóricos y políticos, dando lugar a una pretendida justificación de concepciones y regímenes autoritarios.

Numerosos estudios demuestran que las teorías sobre el supuesto carácter violento innato del ser humano carecen de toda justificación científica, filosófica o religiosa (Punset, 2001). Desde hace varias décadas, la neurobiología, la psicología, la religión, la ética, la economía, la ecología y otros ámbitos del saber han mostrado que la agresión no es inherente a la naturaleza ni a la condición 
humana. En esa línea, un interesante estudio de Rodríguez Vega (2018) establece una relación positiva entre educar para la paz y la "neurociencia de la felicidad responsable".

De igual modo, dichos estudios muestran la necesidad de desvincular, por una parte, la educación de toda visión agresiva que promueva el éxito social fundado en el poder del conocimiento; en tal sentido, la educación desempeña un papel decisivo para construir felicidad en el largo plazo de la persona, influyendo en su personalidad y sus prácticas desde los primeros años y a lo largo de toda su vida, mediante, entre otros, el aprendizaje cooperativo, las habilidades para el diálogo, el control de las emociones, la empatía y las capacidades de negociación de conflictos. Es importante igualmente que de esos aprendizajes se derive la posibilidad de superar la visión de la economía y los negocios como presencia agresiva en los mercados y se pueda avanzar hacia una economía humana como mediación rehumanizadora.

Para mostrar que la violencia no es un impulso innato, Montagu (1978) afirma que "no aparece espontáneamente en ningún ser humano" (p. 253) y, para desvirtuar cualquier condicionamiento genético, añade que "el tipo de conducta que despliega un ser humano en cualquier circunstancia no está determinado por sus genes [...] sino básicamente por la experiencia vivida en interacción con esos genes" (Montagu, 1978, p. 15-16). En la misma línea, Jares (2001) expone sólidos argumentos que establecen una clara separación entre violencia y naturaleza humana, situando la agresión violenta como respuesta equivocada a conflictos sociales, políticos y económicos: "las explicaciones de las causas y alternativas de solución a las agresiones tenemos que buscarlas preferentemente en los sistemas sociales y culturales en los que desenvolvemos nuestra socialización" (p. 4l).

Tales estudios muestran que, en lugar de violencia, el núcleo de lo humano está en el cuidado, la compasión y la cooperación (Marcos y Pérez Marcos, 2018; Mesa, 2005; Punset, 2001) y que la clave está en saber (capacidades) y querer (decisión política) activarlas: a) a través de la educación, para lograr acuerdos ético-valorativos; b) a través de la política, para impulsar mayor responsabilidad 
en la ejecución de políticas de mejoramiento de las condiciones de vida; c) a través de la economía real, para alcanzar mayor equidad en la distribución de los bienes y la riqueza.

Resulta claro, sin embargo, que para poder construir felicidad se requiere la superación de las situaciones de violencia que degradan a las personas y lo que se haga, especialmente en la educación, para avanzar en la construcción de cultura de paz constituirá una base para un proyecto de vida feliz. Para ello, a partir del reconocimiento de la violencia, es importante realizar un esfuerzo de clarificación conceptual sobre categorías compartidas para orientar, valorar y evaluar las acciones concretas, poniendo en discusión el significado real de conceptos como conflicto, violencia, diálogo, negociación, por una parte, o de posconflicto, paz, reconciliación, justicia, por otra, vinculándolos con indicadores que puedan mostrar que se avanza en la dirección adecuada (Acnur, 2019).

\section{Cultura de paz y felicidad}

Superar la cultura de la violencia e ir más allá de la violentología como área de conocimiento dedicada a describir científicamente la violencia es una tarea de la cultura de paz. Esta tiene particular incidencia en el abordaje de conflictos referidos a situaciones puntuales, en las cuales las herramientas como la mediación y la negociación son una oportunidad valiosa para el aprendizaje de ciudadanía democrática y de responsabilidad social (Unesco, 2015). Su incidencia es también valiosa en el análisis crítico de las condiciones sociales, económicas y políticas que obstaculizan la felicidad.

Es en la educación donde los seres humanos se van gestando a sí mismos en un trabajo de humanización que implica un desarrollo reflexivo de la pregunta sobre por qué y cómo convivir y al mismo tiempo si somos capaces de ser felices en la aceptación y la gestión de los límites y de las posibilidades que la convivencia implica. Como lo indica Hannah Arendt (2000), el primer paso es la disposición afectiva: convivir no por obligación, sino sobre la base del afecto, la compasión 
y el cuidado. Es a partir de esa base que pueden darse una inteligencia para ser felices y un lenguaje que hace posible la felicidad como relacionalidad amorosa.

En relación con la historia - de las sociedades, las comunidades y la propia historia-, para ser feliz la persona necesita reconocer y hacer las paces con su pasado, a través del conocimiento, la aceptación y la superación de las consecuencias que las situaciones de violencia hayan dejado en ella. Dejar de ser y de sentirse víctima, rehacer la posibilidad de ser ciudadano y profundizar en la capacidad de ser persona son pasos necesarios en el proceso de avanzar en la posibilidad de ser feliz.

Las estrategias para ello pueden ser múltiples y abarcan un arco de posibilidades que van desde la búsqueda de argumentos racionales hasta las herramientas que se apoyan en los afectos y emociones, la sensibilidad artística o la espiritualidad. Según Paul Ricoeur (2001), la memoria desempeña un papel importante: como poderosa herramienta de armonización de la vida y, entendida como "justa memoria" — entre los extremos de la venganza y la impunidad- ha ayudado y ayuda efectivamente en la recuperación del horizonte de paz y armonía necesario para la felicidad.

En las representaciones sociales de la felicidad, ser feliz ha sido presentado frecuentemente como tener una vida sin conflictos (personales, sociales, ambientales). Esta forma de situarse ante la conflictividad ha pasado por fases que evolucionaron desde un cierto optimismo, ingenuo o interesado (la "eliminación de los conflictos"), pasando por una visión más realista: la "gestión" de los conflictos, para llegar, más recientemente, a una fase reflexiva y crítica centrada en la "transformación" del conflicto y en el "aprendizaje" que todos los actores y la sociedad pueden extraer de este.

Se trata de un cambio significativo que condujo a asumir que la vida feliz alcanza su contenido en contraste con condiciones de diversidad, complejidad y conflictividad (Domínguez, García Serrano, González Losada y Rodríguez Jiménez, 1996) y en definitiva depende de la progresiva, pero urgente, construcción de una lógica de paz que sustituya la idea de que el otro es una amenaza y construya la 
convicción de que es, en la realidad, un interlocutor y un socio y, potencialmente, un amigo y un hermano (Martin-Fiorino et al., 2019). Sobre este proceso y poniendo énfasis en el papel del afecto en la construcción de felicidad, Montagu (1983) señala que "el afecto es una necesidad fundamental, es la necesidad que nos hace humanos" (p. 28).

\section{Discusión}

\section{La antropología personalista y la felicidad}

La discusión de los diferentes aspectos relativos a las condiciones éticas, políticas y educativas para la construcción de felicidad lleva a afirmar que no puede haber felicidad de la persona sin la apertura al otro en la convivencia, pues en el diálogo es el otro quien me otorga el "permiso para ser feliz". En tal sentido, como lo señalaba Emmanuel Levinas (1992), el otro nos compromete antes de todo pacto. Desde el humanismo personalista, por otra parte, no es posible concebir la felicidad sin la compasión por el que sufre, sin la solidaridad con los más vulnerables y sin el ejercicio del cuidado mutuo.

Desde el personalismo, que desarrolla y contextualiza los aportes de una línea de pensadores que incluye, entre otros, a Martin Buber, Emmanuel Levinas, Jacques Maritain, Emanuel Mounier y Karol Wojtyla (Burgos, 2005; López López, 2012), la búsqueda de felicidad remite a un proceso de realización plena de la persona fundado en su libertad, centrado en su dignidad, sus capacidades cocreativas, su capacidad de realizar su proyecto de vida feliz mediante la construcción de comunidad, desde la valoración de la alteridad, en la orientación al bien común y en el cuidado de la "casa común" como responsabilidad con la vida (Papa Francisco, 2015).

En especial, para el ámbito educativo, los aportes de la antropología personalista han abierto nuevas vías para pensar, practicar y comprometerse con la felicidad como realización de un proyecto de vida valioso y compartido. Importantes documentos recientes de la Iglesia católica han abordado el tema de la felicidad, de un modo que renueva su fundamentación y su contextualización, relacionándolo, 
en el marco de los conflictivos contextos contemporáneos, con la práctica de la fe, el compromiso con la justicia y el cultivo de la esperanza y, en una perspectiva de sostenibilidad humana y cuidado de lo común, con la ecología integral, tal como se plantea en la Encíclica Laudato Si'.

\section{Conclusiones}

Los avances en la consideración de la felicidad desde el personalismo la sitúan como aprendizaje a lo largo de toda la vida, como asunción responsable del cuidado de la vida propia y del otro y como sentido de apertura a la trascendencia. Ello le otorga renovada importancia al tema en las sociedades de la indiferencia, el cansancio o la supervivencia y en situaciones apremiantes de riesgos globales de salud y subsistencia económica.

La educación para la felicidad encuentra en la antropología personalista nuevas alternativas para el desarrollo de las capacidades humanas, la primera de las cuales es la capacidad de elegir. En ese sentido, elegir la felicidad es: a) elegir la convivencia en lugar de la supervivencia y trabajar para ello; b) elegir la paz y la negociación; c) elegir la compasión, la solidaridad y el cuidado; d) elegir la justicia, practicarla y exigirla; e) elegir el amor, para vivir en fraternidad.

La elección de un proyecto de vida valioso sitúa a la ética como núcleo, como autoafirmación de la persona y como tejido de valores compartidos para ser comunidad, niveles ambos determinantes de la felicidad posible. Restaurar la capacidad de elección de los más vulnerables requiere la reconstrucción de condiciones concretas para la reciprocidad mediante el desarrollo de un pensamiento de inclusión, estrategias de cuidado mutuo y prácticas de solidaridad, respondiendo a las exigencias de la dignidad humana desde la compasión, la solidaridad y la cooperación.

Ello requiere igualmente relacionar la construcción de felicidad con actividades concretas realizadas en mediaciones como la universidad, los gobiernos, las empresas y las organizaciones para considerarla en la convergencia de un enfoque 
de necesidades (acceso a condiciones de vida digna), un enfoque de derechos (derecho a una vida valiosa) y un enfoque de proyecto (vida trascendente).

La propuesta de un proyecto cristiano de vida feliz (Martínez, 2018) plantea, en perspectiva contemporánea, los contenidos de una vida sabia, pensada desde los ejes de la relación con Dios y con la verdad, unidos a los de una vida solidaria, centrada en el amor, y una vida de servicio, relacionada con el trabajo creativo, la conciencia responsable y la esperanza creadora.

Todo ello plantea como necesaria una resignificación de la teleología de lo humano, una revisión de sus capacidades para gestionar los conflictos y la construcción práctica de mediaciones para la rehumanización. Los caminos son la educación, creando espacios de valores compartidos; la política, ampliando campos de participación y decisión, y la economía humana, mediante una equitativa redistribución de la riqueza que permita la construcción de los proyectos de vida de las personas en armonía con las dimensiones de lo comunitario, lo social y lo ecológico.

\section{Referencias}

Acnur. (2019). Informe migraciones 2019. Nueva York: Publicaciones Acnur.

Arendt, H. (2000). La condición humana. Buenos Aires: Paidós .

Aristóteles. (2001). Ética a Nicómaco. Madrid: Gredos.

Ávila Hernández, F. et al. (2019). Reflexiones sobre nacionalidad, apatridia y derechos de los niños y niñas. Novum Jus (en prensa).

Bauman, Z. (2016). Ética posmoderna. Buenos Aires: Siglo XXI.

Beck, U. (2007). La sociedad del riesgo. Barcelona: Paidós.

Bude, H. (2017). La sociedad del miedo. Madrid: Herder.

Burgos, J. M. (2005). El personalismo. Madrid: Palabra.

Burnett, D. (2018). El cerebro feliz. Bogotá: Paidós-Planeta.

Caldera, J. (2018). La democracia integral. Bogotá: Ciencia y Derecho.

Cortina, A. (2007). Ética de la razón cordial. Oviedo: Nobel.

Cortina, A. (2013). Aporofobia, el rechazo al pobre. Buenos Aires: Paidós. 
Persona, convivencia y felicidad. Condiciones ético-políticas y educativas para la construcción

Culleton, A. (2010). Tres aportes al concepto de persona. Boecio, Ricardo de San Víctor, Escoto. Revista Española de Filosofía Medieval, 17, 59-71.

De Luise, F. y Farinett, G. (2014). I filosofi parlano di felicità. Turín: Einaudi.

Domínguez, T., García Serrano, A.M., González Losada, C. y Rodríguez Jiménez, F. (1996). Comportamientos no violentos. Propuestas interdisciplinarias para construir la paz. Madrid: Narcea.

Fisas, V. (2002). La pazes posible. Barcelona: Nuevas Ediciones de Bolsillo.

Foucault, M. (2006). La política de la vida. Ciudad de México: Siglo XXI.

Gelardo-Rodríguez, T. (2005). La política y el bien común. Navarra: Gráfica Ed.

Galtung, J. (2003). Pazpor medios pacíficos: pazy conflicto, desarrollo y civilización. Bilbao: Bekaez.

Han, B. C. (2017). La sociedad del cansancio. Barcelona: Herder.

Harari, Y. (2016). Homo Deus. Barcelona: Debate.

Hernández-Sampieri, R. (2018). Metodología de la investigación. Ciudad de México: McGraw Hill.

Jaeger, W. (1990). Paideia. Los ideales de la cultura griega. Ciudad de México: Fondo de Cultura Económica.

Jares, X. (2001). Educación y convivencia. Madrid: Popular.

Kliksberg, B. (2003). La agenda ética pendiente de América Latina. Buenos Aires: Paidós.

Lafferrière, J. (2017). ¿Los seres humanos somos meros "algoritmos"? https://repositorio.uca.edu.ar/ handle/123456789/8948

Levinas, E. (1992). Totalidad e infinito. Salamanca: Sígueme.

López-López, A. F. (2012). Karol Wojtyla y su visión personalista del hombre. Cuestiones Teológicas, 39 (91) $119-137$.

Marcos, A. y Pérez-Marcos, M. (2018) Meditación de la naturaleza humana. Madrid: Biblioteca de Autores Cristianos.

Marina, J. A. (2006). Aprender a convivir. Barcelona: Ariel.

Martin-Fiorino, V. (2017). Construir convivencia. Vida política y políticas de la vida. Foro por la Vida; Convivencia, la Persona y su Entorno. Bogotá: Universidad Católica de Colombia.

Martin-Fiorino, V. (2018). Ser humano y autonomía de la acción. El diseño antropológico del pensamiento aristotélico. Bogotá: Universidad Católica de Colombia.

Martin-Fiorino, V. (2019). Conflicto, convivencia y cultura de paz. La resolución de conflictos en ámbito educativo como preparación para la paz. Revista de Cultura de Paz (3), 1-15.

Martin-Fiorino, V. y Holguín, A. (2017). Hacia un nuevo nosotros: la interculturalidad como espacio para la pregunta por el Otro. Revista de Filosofía, 87 (3), 71-82.

Martínez, H. (2019). Proyecto cristiano de vida feliz. Bogotá: ECOE. 
Mesa, J. A., Restrepo, A., Barrera Parra, J. (2005). La educación desde las éticas del cuidado y la compasión. Bogotá: Pontificia Universidad Javeriana.

Montagu, A. (1981). La naturaleza de la agresividad humana. Madrid: Alianza .

Montoya Vásquez, M. (2013). Oriente y Occidente. Un acercamiento al pensamiento oriental. Revista de Filosofía de la Universidad de Costa Rica, LII (134), 41-51.

Nussbaum, M. (2001). La terapia del deseo. Teoría y práctica de la ética helenística. Barcelona: Paidós.

Palacio-Vargas, C. J. (2015). La espiritualidad como medio de desarrollo humano. Cuestiones Teológicas, $42(98), 459-481$.

Paltrinieri, R. (2019). Felicidad responsable. El consumo más allá de la sociedad del consumo. Buenos Aires: Waldhuter.

Papa Francisco. (2015). Encíclica "Laudato Sì". Vaticano: Secretaría de Publicaciones.

Ricoeur, P. (2001). Historia, memoria, olvido. Madrid: Trotta.

Rodríguez Vega, N. (2018). Educar para la paz: la neurociencia de la felicidad responsable. Buenos Aires: Kairós.

Rosas-Giménez, C. A. (2016). Bioética de la esperanza: claves desde la Laudato Sì. Revista Perseitas 4(2), 185-201.

Sapir, E. (2008). El nuevo siglo XxI. Madrid: El Viejo Topo.

Seligman, M. (2011). La auténtica felicidad. Madrid: Zeta.

Sen, A. y Nussbaum, M. (2006). La calidad de vida. Ciudad de México: Fondo de Cultura Económica. .

Téllez, E. I. (2010). El sentido del tejido social en la construcción de comunidad. Revista Polisemia, 10, 9-23.

Unesco. (2015). Educación para la ciudadanía mundial. París: Documentos Unesco.

Unesco-CRES. (2018). Rol de la educación superior ante los desafíos sociales. Córdoba: Universidad Nacional de Córdoba-Unesco.

\section{Bibliografía}

Anrubia, E. y De Rueda A. (2015) (eds.). Felicidad y conflicto. Granada: Comares.

Cortina, A. (2010). Justicia cordial. Madrid: Trotta.

Fromm, E. (2007). La revolución de la esperanza. Ciudad de México: Fondo de Cultura Económica.

Garnica Ríos, F., Ramírez Orozco, S. y Puentes González, W. (comps.). (2013). La persona: origen de sus propias acciones. Bogotá: Universidad Católica de Colombia.

Irizar, L. (2006). Preámbulos de la esperanza. Bogotá: Universidad Sergio Arboleda.

Koleff, M. (ed.) (2009). Acerca del reconocimiento del otro en la cultura contemporánea. Córdoba: Universidad Católica de Córdoba. 


\section{0 - M A E S T R OS}

Persona, convivencia y felicidad. Condiciones ético-políticas y educativas para la construcción

Martin-Fiorino, V. (2009). Desafíos actuales de la ética aplicada. Maracaibo: Universidad Alonso de Ojeda.

Prieto Galindo, F. (2017). Senderos de la Phrónesis. Bogotá: Aula.

Ricoeur, P. (2010). Ética y cultura. Buenos Aires: Pontificia Universidad Católica Argentina.

Riego de Moine, I. (2007). El sí a Dios en tiempos de poca fe. Córdoba: Emmanuel Mounier Argentina. 


\section{6 \\ Justicia y felicidad: un análisis de su relación desde el denominado "derecho a morir dignamente"

\author{
Édgar Antonio Guarín Ramírez* \\ María CRISTINA ROMERO-SiERRA**
}

\section{Resumen}

Este capítulo es el resultado de una investigación en la que se realizó un estudio analítico de la relación entre felicidad y justicia desde el llamado "derecho a morir dignamente”. A partir del marco teórico aportado por el realismo jurídico clásico y la bioética personalista, y un enfoque metodológico centrado en la persona, se indagó si, en la denominada "muerte digna", confluyen los elementos estructurales de un derecho y, por lo tanto, su reconocimiento constituye una materialización de la justicia y un camino para la realización de la felicidad. Como conclusión se encontró que la "muerte digna" constituye, más una posibilidad humana que un verdadero derecho, y que el argumento que se usa referido a la injusticia que genera la negativa de practicarla, así como el que alude a la infelicidad que genera en la persona enferma el hecho de que se niegue su práctica, son objeto de cuestionamiento.

Palabras clave: justicia, felicidad, muerte digna, derecho, realismo jurídico clásico, bioética personalista.

\footnotetext{
* Docente investigador de la Universidad Católica de Colombia, grupo Philosophia Personae. Director dela línea de investigación en Antropología Filosófica. Filósofo y abogado, especialista en Docencia Universitaria, Derecho Administrativo y Derecho Penal; magíster en Derecho Público y doctor en Derecho. eaguarin@ucatolica.edu.co https://orcid.org/0000-0002-3329-1591

** Abogada. Licenciada y magíster en Derecho Canónico por la Pontificia Universidad Javeriana. Coordinadora de Pastoral de la Universidad Católica de Colombia. mcromeros@ucatolica.edu.co
} 


\section{Abstract}

This article is the result of an investigation in which an analytical study of the relationship between happiness and justice was carried out from the so-called "right to die with dignity". Based on the theoretical framework provided by classical legal realism and personalist bioethics, and a methodological approach centered on the person, it was investigated whether, in the so-called "dignified death", the structural elements of a right converge and, therefore, its recognition constitutes a materialization of justice and a path to the realization of happiness. As a conclusion, it was found that "dignified death" constitutes, more a human possibility than a true right, and that the argument used referring to the injustice generated by the refusal to practice it, as well as the one that alludes to the unhappiness it generates in the person becomes ill the fact that his practice is denied, they are questioned.

Keywords: justice, happiness, right to die with dignity, classic legal realis, personal bioethics.

\section{Introducción}

La cuestión acerca de la relación entre la justicia y la felicidad ha sido abordada desde el pensamiento filosófico clásico grecorromano. Sin embargo, en las últimas décadas ha adquirido una especial actualidad por la rehabilitación de la filosofía práctica —especialmente desde la década de 1970—y por los desarrollos que ha hecho la denominada "psicología positiva" sobre la felicidad, los cuales han impactado de manera directa los ámbitos político y jurídico. El número de estudiantes que se inscriben para la cátedra de la felicidad en Harvard - cerca de 1.400 cada semestre en promedio- y cuya orientación tiene un marcado énfasis venido de la psicología positiva, da cuenta de esa especial trascendencia que hoy en día tiene lo relacionado con la felicidad humana.

Empero, la tendencia positiva de la psicología ha sido objeto de algunas críticas, entre ellas quizá la más importante, el que haya dado lugar a una especie de "ideo- 
logía de la felicidad", con un discurso científico que la acompaña, y cuyos postulados básicos según Cabanas e Illouz (2019), muestran la felicidad con estas características:

[...] como un concepto científico y medible; como algo puramente individualista y centrado en uno mismo; como un proceso continuo e insaciable de crecimiento; como la meta más importante que perseguir en la vida; y, por último, como el criterio más relevante para decidir sobre el valor de la propia biografía y el tamaño de los propios éxitos y fracasos. (Cabanas e Illouz, 2019, p. 152)

Como se señaló, la filosofía y la ciencia del derecho no han estado alejadas de esta tendencia "positiva", especialmente desde que el constitucionalismo empezó a tomar fuerza dentro del saber jurídico. En el seno de las reflexiones se habla de la relación que existe entre la justicia y la felicidad de la persona; relación en la que se ha insistido a lo largo del curso de la historia debido al bien que representa el acto de justicia para la persona que lo recibe. La cuestión es que la felicidad y la justicia son conceptos abstractos, razón por la cual, hoy más que antes, son dotados de múltiples significaciones. A su vez, el concepto mismo de derecho se presenta polisémico. Como lo advierte Tomás de Aquino

[...] Es frecuente que los hombres se desvíen de su primera acepción — se refiere a los términos-, para designar otras cosas, como el nombre de medicina se asignó, en un principio, para designar el remedio que se aplica al enfermo para curarlo. Luego pasó a significar el arte por el que se hacía esto. Así también sucede con el nombre de derecho, que se asignó primero para significar la misma cosa justa. Pero, después, derivó hacia el arte con el que se discierne qué es justo; $y$, ulteriormente, a designar el lugar en el que se otorga el derecho; así, por ejemplo, se dice que alguien compare ante el derecho; finalmente, también denomina derecho a la sentencia que es pronunciada por aquel a cuyo oficio pertenece hacer justicia, incluso a pesar de que lo que decida sea inicuo. (Aquino, 1990, S. T. II-II, q. 57, art. 1, ad. 1)

Esta multiplicidad de interpretaciones ha convertido estos conceptos en concepciones teóricas, limitando con ello la posibilidad de que tengan algún tipo de fundamento en la realidad, situación que se complejiza aún más si se tiene en cuenta que ellos están estrechamente ligados a cuestiones de orden práctico, esto es, relacionadas con el orden de la conducta humana, en donde entran en juego la 
libertad y la dignidad humanas, conceptos que también son dotados de múltiples significaciones ${ }^{l}$.

En este contexto, de particular interés resulta lo sostenido por la Corte respecto del que denomina "derecho a morir dignamente". Para el alto tribunal, la vida no consiste

[...] en la subsistencia vital de una persona, sino que va mucho más allá [...] Esos aspectos adicionales son propios de un sujeto dotado de dignidad que, como agente moral, puede llevar a cabo su proyecto de vida. Cuando ello no sucede, las personas no viven con dignidad. Mucho más si padece de una enfermedad que le provoca intenso sufrimiento al paciente [...]. (Sentencia T-544 de 2017)

Empero, esta forma de entender la eutanasia no ha sido pacífica. Desde la ciencia médica se han levantado voces que asumen una postura crítica frente a las tesis de la Corte. La Asociación Médica Mundial (2020) y la Asociación Española de Bioética y Ética Médica (2020), entre otros entes, han reiterado su compromiso con el respeto por la vida humana, por lo que se han opuesto a la eutanasia y a la presión que reciben los médicos para su práctica, sobre la premisa válida de que la dignidad humana no se anula por el dolor y el sufrimiento. La labor del médico es trabajar por restablecer la salud y, en esa tarea, menguar o eliminar el dolor, y no a quien lo padece. Antropológicamente, el dolor y el sufrimiento humano se consideran parte de la condición humana y, por lo tanto, frente a su aparición, la

\footnotetext{
1 En el curso de la historia los diferentes sistemas éticos surgidos en el seno del pensamiento filosófico se han ocupado de los valores y virtudes - entre ellos la justicia - y su relación con la felicidad humana. Este esfuerzo de la filosofía por fundamentar las normas de la conducta humana a nivel del obrar recto, ha llevado a la formulación de diversas teorías que representan algunas formas de ver, de "ser espectador" - como lo sugiere la etimología de la palabra (del griego theoria) - , en desarrollo del pensamiento especulativo (Rodríguez-Adrados, 1980). En este esfuerzo, han surgido éticas adjetivadas como materiales, que relacionan el bien - y las normas de comportamiento que de él surgen - con un bien supremo para el hombre, de manera que, si hay correspondencia de la conducta con ese bien supremo, dicha conducta se calificará como buena. Dentro de estas teorías cabe resaltar la socrática que establece una unión inseparable entre la condición humana y la justicia (Platón, 1988), así como la aristotélico-tomista, que pone la felicidad como el fin último al que todos los hombres aspiran, y que se materializa en las circunstancias concretas mediante el obrar humano que no daña, sino que preserva y, en donde, tanto la virtud de la prudencia, como la naturaleza social y política del ser humano -y allí la virtud de la justicia - cobran particular importancia para alcanzar la felicidad (Aristóteles, 2000, p. 188). También han surgido éticas adjetivadas como formales que no plantean la existencia de bien supremo al que el hombre deba tender, sino que el obrar se deja en manos de la autonomía de la persona o de la construcción histórica y colectiva, producto de la racionalidad humana. A esta corriente pertenecen la ética kantiana, así como aquellas éticas derivadas de la filosofía analítica.
} 
tarea es dotarlos de sentido. Argumentar en favor de la eutanasia sobre la base del pesar y la lástima que pueda provocar una situación de salud calamitosa, además de ser falaz, de ningún modo es una razón justificativa válida para terminar con la vida de una persona.

También han sido múltiples las reacciones que estos fallos sobre la eutanasia han generado en la esfera jurídica. A juicio de los críticos, son cuestionables las nociones de dignidad, libertad, justicia y felicidad que subyacen a estos pronunciamientos judiciales; también causa interrogante el papel de la Corte como legislador positivo, así como el que asuma la función de regular una materia que, constitucionalmente, exige ley estatutaria. Como lo afirmó el magistrado Mauricio González Cuervo en el salvamento de voto del fallo de tutela T-970 de 2014, esta función reguladora no debe ser asumida por la Corte.

Dentro de las cuestiones que suscitan las reflexiones precedentes, hay algunas relacionadas con la filosofía del derecho. A una de ellas se buscó responder con la investigación realizada, cuyos resultados se presentan en este capítulo: iexiste un derecho a morir dignamente cuya negación constituye un acto de injusticia y, por lo tanto, de afectación de la felicidad de la persona? Los resultados obtenidos en el proceso investigativo se plasman en este capítulo en el que el lector encontrará un análisis de la relación entre justicia y felicidad, a partir del llamado "derecho a morir dignamente”, desde el marco teórico que aporta el realismo jurídico clásico y la bioética personalista.

\section{Metodología}

Metodológicamente se procedió de manera analítica. El método analítico permite desintegrar, descomponer un todo en sus partes para estudiar en forma intensiva cada uno de los elementos que lo integran, así como las relaciones entre sí y con el todo. En la investigación que da lugar en este capítulo, el análisis se hizo respecto de los conceptos de justicia, felicidad y derecho, específicamente referido este último al denominado "derecho a morir dignamente". El uso de esta metodología 
ayuda a conocer mejor los objetos de estudio, su naturaleza y características, para poder, de esta manera, comprender con corrección su sentido y alcance.

En el momento de examinar los significados se buscó cuidar de la relación existente entre ellos, sus conexiones y rasgos distintivos propios, a fin de evitar ideas alejadas de la denotación propia de estos. La descomposición o análisis realizado siguió los lineamientos ofrecidos por el realismo metódico, que da primacía al ser sobre el pensar y, por lo tanto, a la realidad sobre el sujeto que la piensa e interpreta. Esta opción epistemológica hoy se encuentra especialmente rehabilitada en el ámbito académico. Como afirma Arthur Kaufmann (1999):

No es que Aristóteles haya solucionado nuestros problemas actuales, pero el modelo clásico sirve para ordenar argumentos y contraargumentos en los discursos cotidianos y procurar claridad para sí y para los demás, cualquiera sea el nivel en que se argumente. (p. 300)

El uso del método analítico posibilitó avanzar en la seguridad de los resultados obtenidos, sin que ello signifique que la discusión en torno a estas materias está cerrada. Para su aplicación se siguieron los pasos de observación, descripción, examen crítico con ayuda de la hermenéutica, identificación de los referentes de cada concepto, orden y clasificación de estos. La hermenéutica, como aplicación de la razón a la interpretación de realidades y textos, sirvió de ayuda para hallar el referente in re de los términos derecho, justicia y felicidad, a fin de explicarlos de manera adecuada.

Como enfoque de investigación se empleó el denominado "enfoque centrado en la persona”, de raigambre personalista, que da la opción de adelantar investigación científica en el campo de las ciencias de la conducta —entre ellas el derecho-, con rigurosidad, sistematicidad y criticidad, sublimando el valor de la persona en su realidad individual y social, con sus características de singularidad, unicidad, autonomía, dignidad y responsabilidad, así como su carácter relacionalinterpersonal (Rogers, 1980, p. 102). Este enfoque investigativo reviste particular importancia y resulta especialmente útil para investigaciones de carácter filosófico-jurídico que parten de la consideración de la persona como fundamento 
del derecho y, por ende, de la justicia que lo realiza de manera efectiva (Guarín, 2013).

El tipo de investigación desarrollado ha sido de carácter correlacional-explicativo porque abordó los conceptos de derecho — aplicado específicamente a la eutanasia-, justicia y felicidad, propendiendo por hallar la relación existente entre ellos en el contexto particular del saber jurídico, además de generar un sentido de entendimiento de estos, a partir del realismo jurídico clásico y la bioética personalista (Hernández-Sampieri, Fernández y Baptista, 2014).

\section{Resultados}

\section{Justicia y felicidad}

Antropológicamente el encuentro con el otro, con el tú, permite a cada persona darse cuenta del significado de su propio yo. Esa presencia del otro es clave para responder los interrogantes fundamentales de la existencia humana, relacionados con lo biológico, lo psicológico, lo social y lo espiritual, dimensiones que integran la realidad personal del ser humano. La noción de persona está ligada a la unicidad del ser humano, a su individualidad propia, que se revela en la comunión interpersonal. De allí que, no solamente la individualidad propia de cada uno, sino también la dimensión alteritiva, sea fundamental en el ser humano. La persona es el ser de la palabra y de la capacidad de encuentro con el otro y, por ende, de su ser se desprende su naturaleza dialogal (Aquino, 2003, p. 895).

Esa presencia del otro es para la persona, por lo tanto, llamada y exigencia de reconocimiento. Dar al otro lo que es suyo, lo que le pertenece, su derecho, hace parte de esa exigencia y se convierte en una forma de promoverle. (Gevaert, 1987, p. 59)

A ese acto de reconocimiento del derecho ajeno se le conoce históricamente con el nombre de justicia.

La reflexión sobre el hombre hecha desde la antropología filosófica descubre la ineludible dimensión interpersonal del ser humano. Empero, algunas tendencias antropológicas actuales navegan impulsadas por vientos opuestos, apoyadas en una noción del hombre individualista que ha llevado a poner en tela de juicio, 
incluso, la existencia de una naturaleza humana común. Esta absolutización del yo, unida a la lógica de la racionalidad económica propia del neoliberalismo, basada en la eficacia y la productividad, da lugar a una sociedad basada en la competitividad que, a su vez, lleva a un estilo de vida insolidario y consumista, con olvido de la responsabilidad que se tiene frente a los otros (Beorlegui, 2003, p. 503). Como afirma Bauman (2011), "hoy la norma es tener capacidad para consumir, de lo cual emerge un criterio de felicidad que rinde cierto culto a elección en donde tiene poca cabida la deliberación" (p. 140). La forma de gobierno que más sirve a este tipo de sociedad es la democrática, a la que se considera progresista ya que proclama la defensa de las libertades, lo cual le sirve de basamento para soportar el individualismo. Esta democracia

[...] se apoya en fuertes poderes coercitivos, que influyen de modo permanente a través de los medios de comunicación masivos, para que todos piensen, decidan y persigan modelos de identificación existencial dictados por los intereses de las minorías dirigentes. (Beorlegui, 2003, p. 504)

Como se refería en la introducción de este capítulo, esta visión individualista, hedonista y esteticista, a juicio de algunos, ha estado alimentada por una concepción de la felicidad relacionada a la psicología positiva. El profesor Tal Ben-Shahar, doctor en comportamiento organizacional, docente de Psicología Positiva y Psicología del Liderazgo en Harvard, autor de libros como: La búsqueda de la felicidad (2011), Elige la vida que quieres (2014) y el escrito con Angus Ridgway Ser felizes decisión tuya (2018), ha logrado tener con sus textos especial impacto en esta materia, ya que ofrecen alternativas para solucionar problemas de orden emocional, los cuales son relacionados directamente con la felicidad humana. En estos textos se desarrolla la idea de que la felicidad depende mucho del estado de ánimo de la persona, el cual, a la vez, depende de aquello en lo que el ser humano decide concentrarse y de la interpretación que haga de los acontecimientos externos en una actitud que el autor denomina optimalista. Según Ben-Shahar (2018)

El núcleo, la esencia, del liderazgo eficaz es la prosperidad y el crecimiento personales [...] dicho de otro modo, en el mundo desagregado de hoy, donde todos los empleados de una organización tienen la libertad de interpretar por sí mismos lo que se supone 
que deben hacer, la mejor manera de pensar en el liderazgo es vinculándolo con el crecimiento y la prosperidad personales. (p. 19)

A juicio de Cabanas e Illouz (2019), de esta manera de entender la felicidad surge la creencia de que una persona que se siente bien y es feliz es una buena persona, mientras que quien no lo hace es una mala persona, con lo que se establece una relación directa entre lo emocional y lo moral. Así mismo, se establece una relación entre el sentirse bien, el irle bien a la persona en la vida y el ser feliz, de manera que, al que se siente bien le va bien y, por ende, es feliz; a quien no se siente bien no le va a ir bien y, por ende, será infeliz (pp. 154-157). Así pues, se censura a la psicología positiva porque en ella hay lugar a una especie de reducción de la felicidad a aspectos emocionales, relacionados, a su vez, con el bienestar y el éxito en la vida. Esto ha llevado a algunas personas a la idea de que tener padecimientos - como los que se causan por las enfermedades-, no es compatible con la felicidad verdadera y a pensar que sufrirlas afecta de tal forma el bienestar e, incluso, la misma dignidad de la persona — que es asociada directamente con la libertad-, que cuestionan que vivir en medio de esas situaciones sea una "de calidad".

Una visión más holística de la felicidad permitiría incluir dentro de ella, no solamente el éxito, la salud, el bienestar, la capacidad de superar obstáculos, sino el reconocimiento de que dichos obstáculos siempre estarán presentes y que se puede ser feliz en medio de ellos, razón por la cual no afectan la "calidad de vida" de una persona. La felicidad encierra todas las realidades existenciales de la persona y, por lo tanto, pretermitir el sufrimiento puede llevar a las personas a tener poca capacidad de frustración frente a los avatares de la vida. En esta línea de pensamiento, Viktor Frankl (199l), al hablar del sentido de la existencia humana, refiere:

Cuando uno se enfrenta con una situación inevitable, insoslayable, siempre que uno tiene que enfrentarse a un destino que es imposible cambiar, por ejemplo, una enfermedad incurable, un cáncer que no puede operarse, precisamente entonces se le presenta la oportunidad de realizar el valor supremo, de cumplir el sentido más profundo, cual es el 
del sufrimiento. [...] El sufrimiento deja de ser en cierto modo sufrimiento en el momento en que encuentra un sentido, como puede serlo el sacrificio. (p. 113)

Para Frankl, lo que precisa el hombre para ser feliz no es negar ni eludir la existencia de situaciones existenciales que le resultan incómodas y poco placenteras, sino el reconocimiento de estas, y la fortaleza para enfrentarlas².

Esta dialéctica en torno a la felicidad ha permeado también el ámbito jurídicopolítico, especialmente por los desarrollos realizados en el derecho constitucional. La Corte Constitucional colombiana en la Sentencia T-881 puso de presente desde el año 2002 que la dignidad humana - a la que considera principio fundante del ordenamiento jurídico — se encuentra directamente relacionada con el ejercicio de la libertad. Para la Corte, la dignidad está integrada por la autonomía (vivir como quiera), el goce de ciertas condiciones materiales concretas de existencia (vivir bien) y por otros bienes no patrimoniales como la integridad física y la integridad moral (vivir sin humillaciones). Esta relación entre dignidad y libertad ha sido resaltada en otras decisiones como la contenida en la Sentencia C-355 de 2006 que refiere al respeto de la libertad de la mujer que decide abortar, como un acto de consideración a su dignidad. Por esta vía se ha establecido un eslabón que une los conceptos de dignidad y libertad con el de felicidad. En la Sentencia T-673 de 2013, la Corte sostiene que el rechazo a una determinada opción de vida (que hace parte del derecho al libre desarrollo de la personalidad) conlleva el que la persona se sienta insatisfecha, no identificada consigo misma e infeliz, con lo cual se afecta, además, otro derecho: la legítima aspiración a la felicidad (Sentencia T-622, 2016).

Estas premisas han estado presentes en los fallos del Alto Tribunal referidos al respeto por la vida humana, entre ellos, los relacionados con el tema de la eutanasia. El primer acercamiento del alto tribunal sobre el particular se dio en la

\footnotetext{
2 En un documento publicado en la Revista de Psicología Social, Gabriela Rodríguez Hernández (2019) plantea que centrar la felicidad en las emociones positivas y en la satisfacción de la vida corresponde a una perspectiva hedónica de esta, a la cual se contrapone aquella que prioriza una vida significativa, a la que llama perspectiva eudemónica de la felicidad. Los hallazgos obtenidos, a juicio de la autora, contribuyen a explicar por qué la población de México, en la que se aplicó el estudio, muestra altos niveles de felicidad a pesar de que se ubica por debajo del promedio en casi todos los indicadores de calidad de vida.
} 
Sentencia T-493 de 1993 en donde resolvió revocar una providencia del Juzgado Promiscuo de Ituango Antioquia, en consideración a la protección de los derechos del libre desarrollo de la personalidad y de la intimidad personal y familiar de una mujer enferma de cáncer de mama, que rehusó a acceder al tratamiento médico que ordenaba dicha providencia. Posteriormente, cuatro años después, inició la línea jurisprudencial con la Sentencia C-239 de 1997 que le dio a la eutanasia la categoría de derecho fundamental, hasta llegar a la Resolución 825 de 2018, en la que el Ministerio de Salud, siguiendo lo mandado por la Corte Constitucional, reglamenta el procedimiento para hacer efectivo el derecho a morir con dignidad de los niños, niñas y adolescentes.

Según la Corte, el derecho a morir dignamente tiene la categoría de fundamental porque busca garantizar la dignidad del ser humano, y su principal propósito es permitir que el significado de la vida como derecho vaya más allá de la subsistencia vital de una persona, de manera que, cuando por el hecho de padecer una enfermedad que provoca intenso dolor y sufrimiento la persona no puede realizar su proyecto de vida, ella puede disponer de su propia vida (Sentencia T-544, 2017). En el trasfondo de estas afirmaciones está la idea de que la vida digna y feliz se relaciona directamente con la posibilidad de decidir sobre la propia vida, y que dicha dignidad y felicidad riñen con el sufrimiento que provocan las enfermedades terminales.

Algunas corrientes antropológicas posmodernas sirven de arbotante a las tesis que asocian los conceptos de dignidad, libertad y felicidad. Para estas corrientes, los referentes y las explicaciones globales u omniabarcantes de los conceptos dejaron de tener validez y valor explicativo, lo que ha dado origen a un pensamiento "débil" y su interpretación laxa de la existencia (Vattimo, 1983), y "líquido" (Bauman, 2000).

en el que hay lugar a una ruptura con las instituciones y estructuras fijadas, y un marcado acento individualista, temporal, inestable y carente de soportes sólidos. En la sociedad débil y líquida los conceptos se tornan concepciones parciales y provisionales, lo que desemboca en relativismo, hedonismo y esteticismo. (Beorlegui, 2003, p. 504) 
"Además, este tipo de antropología alimenta una apología al libre albedrío que resulta bastante seductora, especialmente para las generaciones emergentes" (Bauman, 201l, p. 53). En este contexto, la justicia y la felicidad se vuelven inseparables, y su eslabón es el respeto por el libre desarrollo de la personalidad de cada individuo, derecho con el que, como se ha indicado, se vincula estrechamente la dignidad humana, lo cual tiene importantes implicaciones para la vida personal y comunitaria, lo cual demanda una comprensión de la realidad de la justicia y de su importancia para la vida social, que vaya más allá de la mera individualidad.

Si bien es cierto que para algunos sectores que apoyan las decisiones del Alto Tribunal, la libertad es el eje gravitacional sobre el que giran todos los demás derechos de la Carta Política de 1991 y, por ende, su indebida limitación atenta con la dignidad propia del ser humano que, en cuanto ser racional, puede decidir sobre su propia vida sin limitaciones, para otros sectores hay problemas con los principios de demostración que son empleados por la Corte, relacionados con los conceptos de derecho, justicia, libertad, dignidad y felicidad. Además, de particular relevancia ha sido la crítica que se ha levantado por la limitación establecida por la Corte al derecho a la objeción de conciencia consagrado en el artículo 18 de la Constitución Nacional, cuyo contenido señala con claridad meridiana que "nadie será molestado por razón de sus convicciones o creencias ni compelido a revelarlas ni obligado a actuar contra su conciencia". No obstante, según el artículo sexto de la Resolución 1216 de 2015 del Ministerio de Salud y Protección Social, el Comité Científico-Interdisciplinario para el Derecho a Morir con Dignidad debe ser conformado por un médico con la especialidad de la patología que padece la persona, diferente al médico tratante, un abogado y un psiquiatra o psicólogo clínico, y ninguno de los tres puede ser objetor de conciencia.

Como afirma Lorca Martín (2013), "conviene tener presente que la felicidad no es solo un objetivo individual, algo reductible exclusivamente al ámbito de lo privado, sino que también es un asunto de interés público" (p. 296).

Todos los seres humanos compartimos una misma identidad esencial y una misma naturaleza, de manera que la sociedad deviene de lo que la persona humana 
es en sí misma y, por lo tanto, la dimensión interpersonal no puede dejarse de lado cuando se trata de abordar la cuestión sobre la felicidad del individuo (Berg, 1964).

Esta socialidad humana abre a un modo de relacionarse que

[...] se manifiesta en la sustitución del instinto y las fuerzas naturales gregarias (inexorables) propias de los animales, $\mathrm{p}$ or una apertura de la ontología de la persona o inclinatio naturalis (corpóreo-espiritual) que se traduce en una comunicación por el conocimiento y el amor. (Hervada, 2000, p. 460)

Esta socialidad es, a su vez, el fundamento de la justicia y, por lo tanto, un aspecto esencial en la consecución de la felicidad. En efecto,

[...] es en esta especial y particular condición del ser humano en donde se funda la justicia, en la cual opera un principio de reconocimiento del otro [...] y, aunque es posible fundar la relación de justicia sobre una base distinta, hacerlo implica el vaciamiento del ser y razón de ser de la misma porque en la relación de justicia se afirma la identidad misma de la persona en cuanto ser capaz de poseerse y tener cosas como suyas, cuyo respeto puede ser exigido a los otros, sin lo cual, no puede haber verdadera sociedad ni convivencia pacífica. (Horta y Guarín, 2018, p. 112)

Esta noción de justicia, que se establece en torno a los derechos de las personas, y sin cuyo respeto se trunca la felicidad humana, va más allá de toda forma de individualismo y conduce a que lo propio de cada persona forme un todo que expresa la unidad ordenada de las muchas partes, en la cual, la pluralidad de los muchos se incorpora a lo uno para alcanzar el bien de todos (Aristóteles, 2000, p. 67).

El objeto propio de la justicia es el derecho. A este objeto la tradición filosóficojurídica clásica denominó ius, y corresponde a aquello que el deudor está llamado a dar al acreedor: "suum cuique tribuere" (Aquino, 1990, S. T. II-II, q. 57, art. 4)3.

3 El derecho —objeto de la justicia - tiene tres características básicas: aliedad, igualdad y externalidad. La primera significa que la justicia es ad-alterum, esto es, tiene por destinatario a otro, a una persona distinta del agente que realiza el acto de justicia. La segunda, que a través del acto justo se le da al otro exactamente lo suyo, ni más ni menos, según lo prescriba el título - natural o positivo- y la medida de dicho derecho. La justicia, por tanto, trasciende el interés personal; en ella la voluntad humana va más allá del propio yo y realiza un bien para el otro (García-Estébanez, 1990, p. 459). La tercera implica que, como la justicia consiste en dar lo que respecta al derecho, solo si la cosa propia de alguien puede ser objeto de actividad de los demás, podrá ser objeto de la justicia. Lo que permanece en la conciencia o en los pensamientos de la persona, lo que se mantiene en la intimidad, no entra en las relaciones con los otros, y, en consecuencia, no es objeto de la justicia (Hervada, 2000a, pp. 82-85). 
Solamente si quien tiene el debitum respecto del derecho no cumple con su obligación de darlo, se precisa la intervención del juez para hacer efectivo dicho derecho porque el derecho preexiste al acto de administración de justicia que realiza el juez. A quien institucionalmente se le ha revestido con el poder de responder a la exigencia real de justicia que reclaman las personas es a los jueces, y lo deben hacer más allá de sus propios intereses, convicciones o tendencias ideológicas (Guarín, 2016, p. 59).

Como sostiene Carlos Cardona (1973): “A ningún hombre sensato le importa nada que sus razonamientos sean técnicamente impecables, formalmente de una lógica rigurosa, si se separa de la realidad, si han perdido el contacto con lo que realmente es" (p. 44). Lo anterior significa, entonces, que la función de administrar justicia tiene una particular importancia en la felicidad humana.

La realización efectiva de los derechos mediante el acto de justicia - ya sea realizado por el deudor de manera no coactiva, o sea imperado por un juez mediante una sentencia-, constituye para el acreedor o titular del derecho un bien que, en cuanto tal, es causa de felicidad. Históricamente se ha establecido una relación inescindible entre el bien y la felicidad ${ }^{4}$.

La dificultad que trae consigo el definir conceptos abstractos como el de felicidad no implica el desconocimiento de su relación con aquello que preserva - el bien-, y con dimensiones básicas, cuya protección corresponde al Estado mediante la garantía de derechos. (Finnis, 2000, p. 210)

Esta protección deviene necesaria para la realización de la persona y, por lo tanto, está en directa relación con el sentido de la felicidad humana. La etimología de la palabra felicidad refiere a dicho sentido. Tanto el griego eudaimonia (buen espíritu) como la voz latina felicitas (fecundidad o fructificación) dan cuenta de esa estrecha relación que, en el curso de la historia, se ha establecido en la felicidad y el bien (Aquino, 1990, S. T. II-II, q. 2. art. 1).

4 No es el objeto de este capítulo reflexionar sobre el "derecho a la felicidad" del que ha hablado la Corte Constitucional en varios fallos, entre ellos: sentencias C-542 de 1993, T-319 de 2019, T-278 de 1994, T-384 de 2018, T-411 de 1994, T-622 de 2016, T-970 de 2001, T-060 de 1995, T-823, 1999. Para ahondar en este aspecto puede leerse el texto de Alvarado (2016) sobre el derecho a la felicidad. 
El bien provoca en el individuo fruición y, por ello, se relaciona —e incluso se ha identificado - con naturalidad el bien con la felicidad (Aristóteles, 2007). Por eso, las reflexiones en torno a la racionalidad práctica hacen énfasis en que el hombre que obra bien forja, con su actuar, su felicidad, lo cual, a su vez, le sirve de basamento para llegar a amar a los demás en quienes proyecta su amor propio (Fromm, 1986). La realización efectiva de los derechos que ha lugar en el acto de justicia representa un bien para la persona titular de estos y, por lo tanto, es un elemento fundamental en la consecución de su felicidad.

En este orden de ideas, la relación entre justicia y felicidad es real, y no meramente lógica mental, porque se puede constatar como un hecho de experiencia. Ahora bien, la cuestión es si, en lo que refiere a la eutanasia o "derecho a morir dignamente", se está frente a un verdadero derecho y, por lo tanto, su aplicación contribuye, por la vía de realización de la justicia, a la felicidad de la persona. De ello se ocupan las siguientes líneas.

\section{La eutanasia: ¿verdadero derecho? 5}

Todo derecho, para ser tal, exige un título y un titular, una medida y un fundamento, que posibilitan su exigibilidad frente a los otros, quienes tienen la obligación de respetarlo. Estos elementos son estructurales de cualquier derecho y, si alguno de ellos falta, no se puede hablar de su existencia. El título es el punto de partida de todo derecho y corresponde a la causa de atribución de la cosa a un sujeto determinado. Sin título no es posible saber cuándo algo es lo justo, es decir, cuándo es un derecho de alguien, de manera que sin título no hay derecho. Hervada (2000), refiere sobre el particular que

[...] puede ser título todo aquello que es capaz de producir la atribución de las cosas y, por lo tanto, contiene un poder o dominio en acto. En breves palabras, los títulos pueden ser: el contrato, la ley, la costumbre, los actos de gobierno y la naturaleza humana. (p. 205)

5 Este apartado sigue de cerca el trabajo de investigación realizado por una de las autoras, la doctora María Cristina Romero, con el fin de obtener el título universitario de abogada en la Universidad Católica de Colombia. 
El título, en cuya virtud algo pasa al dominio de alguien, puede ser natural cuando ese algo en cuya virtud el hombre se torna en dominador, inhiere a su propia realidad personal, o puede ser positivo cuando el dominio es atribuido por la voluntad humana - ley positiva, costumbres, contratos, etc. - . A diferencia del título natural que no es establecido por el hombre sino "desvelado" por él gracias a su condición racional, el título positivo es puesto por el hombre.

Existe la posibilidad de que alguien considere tener un derecho invocando un título no legítimo, lo cual le quita la característica de ser legítimo titular, de lo que se sigue que otra propiedad inherente al título es su legitimidad. La justicia está determinada por esta relación específica que existe entre el sujeto - y el cubrimiento de su deuda-, con respecto al legítimo titular del derecho, quien debe tener un título legítimo para poder exigir la realización de su derecho (Pieper, 2001, p. 108).

Así pues, como acontece en todo derecho, de existir realmente el "derecho a morir dignamente”, de él se exige la presencia de un título legítimo. Ese título puede provenir de la propia realidad personal del ser humano o de la decisión del ser humano, como se indicó. La existencia y validez del título natural, es decir, de aquel que proviene de la condición personal del ser humano, está consagrada en la misma Constitución Política de Colombia que establece en su artículo quinto que "El Estado reconoce, sin discriminación alguna, la primacía de los derechos inalienables de la persona [...]". El verbo que emplea la Carta Política es "reconocer", con lo cual se indica que en Colombia se confiesa la dependencia y subordinación en la que el Estado se encuentra respecto de dichos derechos inalienables, que es base para el ejercicio de la autoridad y la jurisdicción que se ejerce. Así pues, no es el Estado el que crea dichos derechos - entre ellos la vida-, sino que se sujeta a ellos; por ende, su título no es positivo, sino natural. El derecho más elemental y primario es el derecho a la existencia porque es aquello más fundamental del viviente humano, sobre el que se asientan todos los demás derechos (Zabalza-Iriarte, 1993, p. 49). 
Ahora bien, los actos humanos o actos de libertad — llamados así porque en ellos participan las dos potencias superiores del hombre, a saber, su inteligencia y su voluntad-, pueden ir consonancia o en contravía de la inclinación natural del ser humano a preservar su vida en razón de múltiples circunstancias y no por ello se convierten en actos jurídicos; el hombre, producto de su libre albedrío o capacidad de elección — uno de los elementos que integran su libertad— puede pretender muchas cosas, incluso algunas que atentan contra su propio ser, que no necesariamente son derechos porque, para ser tales, se precisa la existencia de un título, tal como se ha indicado. Por ende, si la inclinación natural del ser humano es a la preservación, en el pretendido "derecho a morir dignamente" no existe título natural. La pregunta es si existe un título positivo.

En Colombia, dada la tradición jurídica que ha heredado del derecho romano, el título positivo lo da el legislador y, excepcionalmente, el ejecutivo. Así se encuentra consagrado en la Constitución de 1991. Los jueces no pueden constituir títulos, salvo que la misma ley los faculte para hacerlo, como en el caso de la prescripción adquisitiva de dominio. Esta limitación está en consonancia con el ser y misión de la función judicial, esto es, la de administrar justicia, lo cual exige la preexistencia del derecho, a cuyo servicio están los jueces. La facultad que tienen las cortes constitucionales en el mundo de confrontar una ley con la norma superior les permite ser "legisladores negativos", pero no positivos.

La Corte Constitucional colombiana en la Sentencia C-239 de 1997 fijó algunos criterios para que el Congreso legislara sobre el "derecho a morir dignamente" y estableciera pautas, criterios, procedimientos, etc., a fin de materializarlo. En vista de que el legislativo no expidió tal norma, en la Sentencia T-970 de 2014, la Corte decidió ordenar al Ministerio de Salud que emitiera una directriz y dispusiera de todo lo necesario para que los hospitales, clínicas, IPS, EPS y, en general, prestadores del servicio de salud, cumplieran con las obligaciones relacionadas con la eutanasia, contenidas en dicha decisión. Consecuencia de esa orden de la Corte se expidió la Resolución 1216 de 2015, en virtud de la cual se han practicado varios procesos eutanásicos en el país. 
Además de ser censurada por legislar positivamente y reglamentar situaciones jurídicas asumiendo el ejercicio de funciones que no le son propias, al tribunal constitucional también se le reprocha el no consultar con el constituyente primario. Desde diversos sectores académicos se ha denunciado el hecho de que la Corte Constitucional, en algunos de sus pronunciamientos, ha carecido de las miras necesarias para calcular los efectos de sus sentencias, además de no consultar con el constituyente primario. No es constitucional que el poder constituyente derivado aumente sus poderes para hacerlos equivalentes a los del poder constituyente originario. Así, las cortes constitucionales tienen limitaciones impuestas por el poder constituyente originario, cuyo franqueamiento no les está permitido (Nogueira-Alcalá, 2009). Uno de esos límites es el de no interpretar lo que aparece en el texto constitucional con meridiana claridad, como acontece con el artículo ll de la Carta de 1991, que refiere al derecho a la vida.

En mérito de lo expuesto, la existencia de título legítimo para la eutanasia es cuestionable porque no existe en Colombia una ley proferida por el Congreso de la República - ley que ha de ser estatutaria por su objeto- que avale su práctica y, dado que sin título no hay titular, tampoco podría hablarse de un titular del derecho en la eutanasia. La administración de justicia es un acto segundo porque requiere, previamente, la existencia de un derecho, el cual, a su vez, exige la existencia de un título legítimo que lo origine. Lo primero que debe hacer el juez para decir el derecho es determinar el titular o acreedor, lo que conduce a averiguar, en virtud de qué título la cosa pertenece y está atribuida al acreedor o titular. No es de su resorte crear el derecho (Hervada, 2000a, p. 204).

La condición de titular faculta al titular del derecho para exigir, en el marco de las relaciones interpersonales, su respeto o satisfacción. A esta facultad se le llama derecho subjetivo, que solamente nace sobre la base de la existencia previa de un derecho objetivo, esto es, las cosas corporales e incorporales que, legítimamente, son propias de una persona y que constituyen un bien exteriorizado, alteritivo y exigible por la vía de la coactividad (Zabalza-Iriarte, 1993, p. 79). 
Sin el elemento de exigibilidad no ha lugar el derecho. El derecho subjetivo solo podrá ejercerse allí donde los sujetos tengan cosas suyas, atribuidas por la naturaleza o por atribución de ley positiva legítima y que, en cuanto tal, no puede ir en contra de lo debido al ser humano por naturaleza.

La facultad de exigir o derecho subjetivo aparece en un segundo momento respecto de la deuda. La cualidad de debida es cualidad de la cosa; la misma cosa es la debida y exigible, por lo que ella misma es jurídica, es derecho, es ius (Zabalza, 1993, p. 21).

En el caso de la eutanasia no existe la exigibilidad porque quien la puede practicar (el médico), puede objetar de conciencia. La misma Corte Constitucional ha reconocido este derecho del médico, aunque cada vez con más limitaciones. Frente a la existencia de un derecho legítimo, originado en título legítimo, no cabe objetar de conciencia porque, precisamente, lo que exige la conciencia es actuar en justicia. Fernando Sánchez Torres, expresidente de la Academia Nacional de Medicina, frente a las decisiones de la Corte y de las resoluciones del Ministerio de Salud respecto a la eutanasia, ha manifestado abiertamente que la objeción de conciencia es un derecho del médico y que, por lo tanto, la decisión de un galeno de no realizar dicha práctica constituye un derecho (Sánchez-Torres, 2018). Además de título legítimo y titular, todo derecho tiene una medida. Ella refiere a la delimitación de la cosa debida, a las facultades jurídicas que competen al titular, así como a los presupuestos y requisitos de uso del derecho. "Por medida del derecho se entiende, pues, un conjunto de aspectos del derecho, que corresponden al qué, cuánto, cómo, dónde debe darse para satisfacer el derecho e igualmente en relación con el correcto uso y ejercicio del mismo" (Hervada, 2000a, p. 206). En este entendido se puede decir que no existen derechos ilimitados, ni todos los derechos son iguales, por eso a cada derecho le corresponde su medida y determinarla, en algunos casos, puede ser algo especialmente complejo. Sobre la premisa de considerar la eutanasia como derecho ¿cuál sería su medida? 
En el "derecho a morir dignamente", el "algo" que constituye el ius, es la muerte, y a la muerte se le agrega el calificativo de "digna" para referir a la eliminación de los dolores intensos que produce una enfermedad terminal (Fonnegra, 2006). Realmente la muerte no es un derecho, sino un hecho ineludible e inevitable para quien tiene vida. Empero, en la eutanasia el derecho legítimo es, realmente, a no tener padecimientos, a lo cual ayuda la medicina, cuyo objeto de estudio no es la muerte, sino la salud. Lo que es digno, entonces, no es la muerte sino la vida en los momentos previos a que la muerte acontezca. Allí se puede ver con claridad la medida del derecho a través de los cuidados paliativos y la compañía de los seres queridos. No hay medida del derecho en la muerte, sino en la vida.

Deviene contradictorio pensar que la realización efectiva de ese derecho se realice con la eliminación de la existencia del individuo que sufre, así sea por solicitud de él mismo, a quien la Corte le ha facultado para disponer de su vida, asunto cuestionable jurídicamente si se tiene en cuenta que la libre disposición del cuerpo y de la propia existencia tienen importantes limitaciones en Colombia. Por eso, una persona no puede pedirle a otra que la asesine y pretender que, quien accede a dicho petitum, quede impune.

Aunado a lo anterior está el hecho de que, no en pocos casos, las personas que tienen graves padecimientos tienen limitada su capacidad de juicio, y aún más cuando no cuentan con el afecto de sus seres queridos. Jurídicamente la capacidad constituye uno de los requisitos mínimos de validez de los actos jurídicos. Como se afirma en la Carta de los Agentes Sanitarios (1995),

Cuando las condiciones de salud se deterioran de modo irreversible y letal, el hombre entra en la fase terminal de la existencia terrena. Para él, el vivir se hace particular y progresivamente precario y penoso. Al mal y al sufrimiento físico sobreviene el drama psicológico y espiritual del despojo que significa morir. (p. 115)

Esta dificultad es reconocida por la propia Corte Constitucional al afirmar que frente a la eutanasia

[...] es necesario que se establezcan regulaciones legales muy estrictas sobre la manera como debe prestarse el consentimiento y la ayuda a morir, para evitar que en nombre del 
homicidio pietístico, consentido, se elimine a personas que quieren seguir viviendo, o que no sufren de intensos dolores producto de enfermedad terminal. Esas regulaciones deben estar destinadas a asegurar que el consentimiento sea genuino y no el efecto de una depresión momentánea. (Sentencia C-239, 1997)

Respecto a la eutanasia, quien tiene la obligación de dar el supuesto "derecho" al enfermo es un médico. En Colombia, cualquiera otra persona que acabe con la vida de un enfermo que tiene intensos dolores, así sea por solicitud de este, comete homicidio pietístico y tiene que responder penalmente; pero si se trata de un médico, que por expresa disposición de la ley tiene que "velar con sumo interés y respeto por la vida humana, desde el momento de la concepción”, no hay responsabilidad sino garantía de derechos. Esto es abiertamente inconsistente y paradójico: a aquel a quien se le ha confiado el cuidado de la salud y de la vida de las personas, ahora se le faculta para terminar con ella.

El galeno de la salud Jorge Merchán-Price (2008), al exponer algunas razones por las cuales la práctica de la eutanasia no es propia de la actividad médica, afirma que:

La acción de matar no es un acto médico terapéutico. No restablece la salud y tampoco preserva la vida. La única forma de entender la acción de matar como un acto "terapéutico" es considerando al enfermo no como lo que es, un enfermo, sino como una enfermedad. En ese caso la acción "terapéutica" de matar se constituye en una acción de limpieza social eugenésica y eso simplemente no es aceptable para el médico [...] La misión fundamental y la razón de ser del médico es el respeto por la vida ("biológica") humana. Por eso reza también en el juramento aprobado por la convención de Ginebra que el médico promete "velar con sumo interés y respeto por la vida humana; desde el momento de la concepción y, aún bajo amenaza, no emplear mis conocimientos médicos para contravenir las leyes humanas". Y, sin duda, "matar" es una contravención a las leyes humanas y también a las leyes "jurídicas y constitucionales" de Colombia cuando el bien protegido no tiene el mismo valor que el bien sacrificado [...] Si un paciente cualquiera ingresa al servicio de urgencias por estar mortalmente herido e inconsciente como consecuencia de un acto suicida fallido, y el médico por las razones que expresa la Corte, y además por solidaridad con la intención suicida del paciente, no lo opera y lo deja morir, con seguridad será "linchado" una vez abandone el hospital. Esto demuestra que la sociedad espera que sus médicos restablezcan la salud y preserven la vida de sus pacientes. Los médicos, además, no salvan vidas para luego cerciorarse si el paciente 
cumple con los requisitos legales que posteriormente (unos días más tarde) le permitan matarlo. Pretender que los médicos maten a sus pacientes es lo mismo que desconocer el pensamiento cultural y la moral general de un país como el nuestro. Y desconocer aquello es lo mismo que desconocer el espíritu integral de la Constitución Política de Colombia. Insisto nuevamente, como ya lo hiciera en otra parte, que la Corte Constitucional no es la Constitución. (Merchán-Price, 2008, pp. 47-49)

El análisis de los elementos constitutivos de los derechos realizado hasta ahora ha puesto de presente algunos reparos a la consideración de la eutanasia como verdadero derecho. A ellos se suma otro de no menor importancia y que está relacionado con el fundamento del derecho. Se llama fundamento del ius a aquello en virtud de lo cual alguien puede ser considerado sujeto del mismo (Hervada, 2000a, p. 232) ${ }^{6}$.

El fundamento del derecho no es, entonces, la fuerza o la violencia, ni el conflicto social, ni los tribunales de justicia, ni el mero querer o deseo de los individuos, sino la persona y su especial dignidad. Por lo anterior, el concepto clave de la ciencia del derecho es la persona. La persona es el único ser viviente que tiene la capacidad de captar y descubrir el sentido de las cosas y de dar sentido a sus expresiones y a su lenguaje consciente. "Desde el momento de la concepción hasta la muerte, en cualquier situación de sufrimiento o de salud, es la persona humana el punto de referencia y de medida entre lo lícito y lo ilícito" (Sgreccia, 1994, pp. 73 y 74$)$.

Reconocer en la dignidad propia de la persona el fundamento de todo derecho ha sido lugar común en la tradición filosófico-jurídica que, por ello, ha insistido en la necesidad de respetar la vida física del hombre en toda su integridad, en especial, la vida y salud de cada ser humano. En la exaltación de la dignidad humana coinciden filósofos de diversa orientación como Tomás de Aquino e Immanuel Kant. Para el primero, la persona es el ser más eminente, el más perfecto de toda

6 Antropológicamente, la especial dignidad de la persona se manifiesta en el dominio que tiene sobre sí y sobre las cosas exteriores a las que, sobre la base de un justo título, puede llamar suyas. Por ello, la ontología de la persona que lo revela como un ser de especial excelencia y elevación, esto es, digno. En este sentido, afirma Millán-Puelles (1984): "La palabra persona, va unida desde su origen al concepto de lo sobresaliente o importante" (p. 457). Esto que es sobresaliente en el ser humano — su dignidad— lo convierte en el único ser biográfico: posee su ser y posee cosas, de modo que atacar este dominio es atacar su estatuto ontológico (Horta, 2009, p. 29). 
la realidad por su naturaleza espiritual manifestada en su racionalidad (Aquino, 1990, I. q. 40, art 3); y para Kant, "Mientras los demás seres tienen únicamente un simple valor de medios, la persona, por el contrario, es de suyo —en sí mismaun fin: algo dotado de ese valor intrínseco que se denomina dignidad" (MillánPuelles, 1984, p. 457). Por su especial dignidad, el hombre es capaz de acciones libres (Melendo y Millán-Puelles, 1996).

La Corte Constitucional en varias sentencias ha señalado que el fundamento de todo derecho legítimamente consagrado - especialmente de los derechos fundamentales - es la persona humana, con su especial dignidad ${ }^{7}$. Con base en ello, el fundamento que invoca para el "derecho a morir dignamente" es la libertad como máxima expresión de la dignidad humana. Empero, la dignidad antecede a toda opción en el uso efectivo de su libertad y, por ende, el hombre no es digno porque posea libertad, sino que es libre porque es digno. Es por ello por lo que la dignidad y la libertad no se pueden igualar. La primera antecede a la segunda; si no fuera así, se imposibilitaría juzgar un acto libre como contrario a la dignidad humana (Millán-Puelles, 1976). Esta dignidad, en palabras de Kant (1983) "se halla por encima de todo precio y, por tanto, no admite nada equivalente [...]” (p. 92). Por eso, dignidad es un término que, referido al hombre, indica una especial excelencia y elevación en su ser, que se enuncia con el término persona. "La referencia a la dignidad como una concepción subjetiva y relativa, vivenciada a través del libre desarrollo de la personalidad, le sustrae de su referente a la realidad íntegra del ser humano en su existencia concreta" (Aparisi, 2013, p. 207). Pretermitir este significado de la dignidad es, como señala Francesco D'Agostino, "vaciar de sentido un orden intrínseco" (2002, p. 179), lo cual tiene importantes repercusiones para en la vida personal y, por ende, para el orden jurídico y social. Respecto de esto, Ilva Myriam Hoyos (1999) señala:

La dignidad humana sería poca cosa si la eminencia de todo ser humano no exigiera que otros le traten como realidad incondicionada. La conceptualización que la Corte Constitucional adopta sobre la dignidad hace que el hombre sea considerado fin 
exclusivamente para sí, no en sí mismo, lo que abre la posibilidad de que el hombre puede ser tratado no como persona sino como cosa. Y si la dignidad es absoluta, no hay ninguna justificación, ni siquiera por motivos humanitarios, para que el hombre, cualquier hombre, todo hombre, también el enfermo terminal, sea tratado como medio. (p. 280)

Fundamentar la eutanasia en una dignidad humana igualada y reducida al libre desarrollo de la personalidad es cuestionable también porque, como afirma el científico Francis Collins (2008), existe una dimensión ética de la acción humana libre que se revela cuando el conocimiento se pone en práctica. Es allí cuando la acción libre es juzgada como buena o mala en la medida en que preserve o dañe. La existencia de la libertad revela la dignidad ontológica, pero es su uso lo que da cuenta o no de la dignidad en el obrar que, cuando se despliega en relación con los derechos ajenos, adquiere una dimensión jurídica. En esta línea de pensamiento, Gonzalo Herranz (2004), resultado de un análisis histórico sobre la eutanasia, sostiene que, cuando se empezó a hablar de la eutanasia en términos de "derecho a morir dignamente", su referente fue

Un derecho que asiste a ciertos seres humanos muy desgraciados, que ya no quieren seguir viviendo porque su existencia está degradada, no por el sufrimiento, sino por la decrepitud biológica, la invalidez dependiente, la demencia insensible, la soledad sin consuelo. No se trata ya de librarse del dolor, sino de una vida que se juzga indigna. En el fondo de la nueva demanda late la idea de que el hombre es señor absoluto de su vida y dueño de su propia muerte, árbitro inapelable de la calidad de su propia existencia, dotado del derecho a decidir autónomamente el momento, lugar y modo de ponerle fin. (p. 19)

\section{Discusión de resultados}

Los resultados de investigación presentados en este capítulo han tenido como objetivo contribuir a la dialéctica que existe actualmente respecto de la relación entre la felicidad y la justicia, referida de manera específica a la eutanasia y su consideración como derecho. Las conclusiones extraídas muestran las dificultades que tiene la consideración de la eutanasia como derecho y llevan a plantearse la pregunta sobre qué hacer, entonces, frente a las personas que sufren una enfermedad terminal. 
Actualmente se considera que son cuatro los principios éticos que ceñen la mayor parte de la bioética, y que son comunes virtualmente a todas las culturas y sociedades:

1. Respeto por la autonomía: el principio de que un individuo racional debe tener libertad al tomar decisiones personales, sin que se le coarte indebidamente desde afuera. Justicia: el requerimiento de tratar a todas las personas de manera justa, moral e imparcial. 3. Beneficencia: el mandato de tratar a los demás en su mejor interés. 4. No maledicencia: no dañar a nadie. (Collins, 2008, p. 260)

La Ley 23 de 1981, por su parte, consagra como principios rectores de la labor médica el respeto por la vida y la dignidad humana, pero no hace referencia explícita al principio de autonomía, sino que alude a él cuando habla de otros deberes del médico, como el de la confidencialidad (Rancichi y Gelpi, 1998). Tampoco hay referencia a este principio en la tradición jurídica clásica recogida en El Digesto, en el que se consagraron tres principios o preceptos fundamentales: vivir honestamente, no hacer daño a nadie y dar a cada uno su derecho: "Iuris praecepta sunt haec: honeste viver, alterum non laedere et suum cuique tribuere”. La pública honestidad y el respeto por las buenas costumbres, el no hacer algo que pueda dañar a la otra persona y el respeto por los derechos ajenos se constituían en las máximas o mandatos de optimización de la conducta humana en el orden jurídico.

Fue con el advenimiento de la modernidad que el principio de autonomía empezó a tener importancia e, incluso, prevalencia sobre cualquiera otro. Ahora, en tiempos posmodernos, esto se ha vuelto aún más palmario. La cuestión es si, realmente, la autonomía —entendida en la forma como lo ha venido haciendo la Corte Constitucional - ha de ser el principio rector que rija la conducta ética y jurídica en materia de eutanasia, o ese principio debe ser repensado y redefinido, a fin de hacerlo consonante con los otros tres, esto es, con los principios de no maledicencia, beneficencia y justicia.

La filosofía jurídica realista y la bioética personalista plantean como alternativa frente a situaciones en las que las personas sufren enfermedades terminales, los cuidados paliativos. Esta nueva especialidad de la medicina observa el problema 
generado actualmente en torno a la muerte desde una perspectiva propia y profundamente humana, en la que la dignidad del enfermo y de sus familiares o personas más cercanas, es el motor fundamental para enfrentar el sufrimiento físico y psicológico que una enfermedad terminal pueda generar. Dichos cuidados hacen a las personas más conscientes de que a pesar de que no se puede curar su ser querido, aún lo pueden cuidar y consolar hasta que su vida fenezca de manera natural. Estos cuidados le dan al enfermo unos bienes que superan lo material y le pueden ayudar a dotar de sentido su dolor. Estudios recientes han mostrado que el materialismo está asociado con una menor autopercepción de felicidad y bienestar, y con una mayor propensión a la depresión (López-Casquete, Muñiz-Velásquez y Gómez-Baya, 2018). En situaciones emocionales que llevan a la depresión las personas no se sienten felices y pueden llegar, incluso, a desear no querer vivir, como acontece en la eutanasia. "Existe una relación estadísticamente significativa entre la felicidad y la inteligencia emocional. Esta relación es directamente proporcional" (Pulido-Acosta y Herrera-Clavero, 2018)

Estos cuidados paliativos se implementan como parte del derecho fundamental a la salud de aquellas personas que padecen enfermedades terminales o complejas, tal y como lo señala la Ley 1733 de 2014):

Esta ley reglamenta el derecho que tienen las personas con enfermedades en fase terminal, crónicas, degenerativas e irreversibles, a la atención en cuidados paliativos que pretende mejorar la calidad de vida, tanto de los pacientes que afrontan estas enfermedades, como de sus familias, mediante un tratamiento integral del dolor, el alivio del sufrimiento y otros síntomas, teniendo en cuenta sus aspectos psicopatológicos, físicos, emocionales, sociales y espirituales, de acuerdo con las guías de práctica clínica que establezca el Ministerio de Salud y Protección Social para cada patología. Además, manifiesta el derecho de estos pacientes a desistir de manera voluntaria y anticipada de tratamientos médicos innecesarios que no cumplan con los principios de proporcionalidad terapéutica y no representen una vida digna para ellos específicamente en casos en que haya diagnóstico de 
una enfermedad en estado terminal crónica, degenerativa e irreversible de alto impacto en la calidad de vida (art. 1).

Con la implementación efectiva de los cuidados paliativos se respeta efectivamente la dignidad de la persona humana que sufre en los momentos previos a su muerte, se facilita a los enfermos los servicios médicos que requieren, se preservan los principios de reconocimiento de la vulnerabilidad, autonomía, integralidad, principio de justicia sanitaria, principio de beneficencia y no maleficencia, entre otros. Colombia aún tiene una tarea pendiente con la reglamentación de los cuidados paliativos. Realizarla facilitará que las personas que tienen enfermedades especialmente calamitosas puedan obtener sus medicamentos esenciales a tiempo, una atención especializada, la posibilidad de tener servicios médicos de calidad en casa, para que, de esta forma, la vida del paciente que sufre sea más llevadera para él y para quienes lo cuidan. Así, las prácticas que se están realizando alrededor de la muerte, basadas en el respeto al principio de autonomía del individuo, no quedarían como una opción para aliviar el dolor físico y psicológico de estas personas.

Actualmente emerge con fuerza la idea de que el individualismo falló y que si realmente queremos la felicidad, se precisa del cuidado personal y del cuidado del otro (Molina, 2015). Esto se hace aún más necesario frente a enfermedades dolorosas que pueden llevar a las personas a pensar que su vida no tiene sentido y a optar por terminar con ella. Jurídicamente, existen otras posibilidades que pueden indagarse y difundirse, y que están en consonancia con la justicia, cuya realización es fuente de felicidad humana. La cercanía del otro y su amistad son aspectos claves para que una persona pueda alcanzar la felicidad, incluso en medio del dolor; la amistad es una categoría fundamental empleada por los filósofos para explicar el significado del crecimiento humano, en medio de las vicisitudes de la vida y permite no pasar por encima del sufrimiento, sino atravesarlo y dotarlo de sentido (Echavarría, 2002). 


\section{Conclusiones}

En este capítulo se realizó un estudio analítico de la relación entre felicidad y justicia desde el llamado "derecho a morir dignamente". De la mano del realismo jurídico clásico y la bioética personalista, y con un enfoque metodológico centrado en la persona que reivindica su especial dignidad como fundamento del derecho y de los derechos, se encontró que la denominada "muerte digna" por parte de la Corte Constitucional colombiana constituye, más una posibilidad por la que la persona puede optar en ejercicio de su libre albedrío, que un verdadero derecho, y que el argumento que se usa referido a la injusticia que genera la negativa de practicarla, así como el que alude a la infelicidad que genera en la persona enferma el hecho de que se niegue su práctica, son objeto de cuestionamientos.

En los resultados de investigación se ha señalado cómo la justicia, en cuanto representa un bien para la persona que, siendo legítimo titular de un derecho, lo ve efectivamente realizado, está estrechamente relacionada con la felicidad humana. Sin embargo, dada la especial complejidad que reviste la definición de estos conceptos, hoy existe una manera de entender la felicidad que está relacionada directamente con lo emocional, convirtiéndola en una obsesión, en un "regalo envenenado", tal como lo afirman Cabanas e Illouz (2019), quienes relacionan esta visión con la psicología positiva que habla de la felicidad en términos de bienestar y el éxito en la vida. Estas ideas han servido de soporte para quienes afirman que el sufrimiento producido por enfermedades terminales no es compatible con la dignidad humana y con la felicidad verdadera porque, en esa visión "positiva" de la felicidad, declarar que no se es feliz, por la razón que sea, es vergonzoso.

Empero, una visión más integral de la felicidad permite incluir dentro de ella, no solamente el éxito y el bienestar, sino también el dolor, y la idea de que se puede ser feliz en medio de él, cuando hay cercanía, acompañamiento y amistad. Como sostiene Frankl (1991), lo que precisa el hombre para ser feliz no eludir la existencia de situaciones existenciales que le resultan incómodas y poco placenteras, sino el reconocimiento de estas, y la fortaleza para enfrentarlas. El sufrimiento y la muerte son realidades presentes en la vida de todo ser humano y, por lo tanto, 
afirmar que su existencia mengua la dignidad de la persona y la felicidad rinde tributo a una forma de entender al hombre y su plenitud que puede ser adjetivada de sesgada. La experiencia muestra que también se puede ser feliz en medio de la enfermedad. La dignidad humana se hace valer en los momentos previos a que el hecho natural de la muerte acontezca, mediante la atención y el cuidado del enfermo.

El análisis de los elementos que integran los derechos ha permitido mostrar las limitaciones que tiene la tesis que sostiene que la eutanasia es, realmente, un derecho que tienen las personas "a morir dignamente". Lo que sí constituye un verdadero derecho es la vida: derecho a que nadie atente contra ella o la arrebate. Más que hablar de muerte digna como derecho, se precisa hablar de derecho a que las personas que se encuentran en el ocaso de su vida sean amparadas, protegidas, cuidadas y acompañadas hasta el último instante. Nada que afecte o atente contra la persona y su especial dignidad puede ser considerado derecho, así sea, en ejercicio de su libre albedrío. La protección jurídica que brinda el Estado debe defender la dignidad personal y los derechos (Sepúlveda, 2009, p. 108).

\section{Referencias}

Ahued, R. (2004). El estatuto del embrión humano. Perinatol, 159-161.

Alvarado, J.-T. (2016). iDerecho a la felicidad? Dikaion, 243-265.

Aparisi, A. (2013). El principio de la dignidad humana como fundamento de un bioderecho. Cuadernos de Bioética, 2(27), 201-221.

Aquino, T. (1990). Suma Teológica. Barcelona: Biblioteca de Autores Cristianos (BAC).

Aquino, T. (2003). La monarquía. Al rey de Chipre. En T. Aquino, Opúsculos y cuestiones selectas (pp. 884 956). Madrid: Biblioteca de Autores Cristianos (BAC).

Aristóteles. (2000). La política. (M. B. Jáuregui, trad.). Bogotá: Panamericana.

Aristóteles. (2007). Ética a Nicómaco. Buenos Aires: Colihue.

Asamblea-Nacional-Constituyente. (1991). Constitución Política de Colombia.

Asociación Española de Bioética y Ética Médica. (2018, 19 de octubre). Conclusiones de la Jornada Anual de AEBI y Comunicado de AEBI sobre la Eutanasia. http://aebioetica.org/archivos/Conclusiones_y_comunicado_final.pdf 
Asociación Médica Mundial. (2019, 21 de noviembre). Declaración de la AMM sobre la eutanasia y suicidio con ayuda médica. https://www.wma.net/es/policies-post/ declaracion-sobre-la-eutanasia-y-suicidio-con-ayuda-medica/

Barrera-Herrera, A. y Vinet, E. (2017). Adultez emergente y características culturales de la etapa en universitarios chilenos. Terapia Psicológica, 47-56.

Bauman, Z. (2000). Modernidad líquida. Ciudad de México: Fondo de Cultura Económica.

Bauman, Z. (2011). Trabajo, consumismo y nuevos pobres. Barcelona: Gedisa.

Beauchamp, T. y Childers, J. (1994). Principles of Biomedical Ethics. Nueva York: Oxford University Press.

Ben-Shahar, T. (2011). La búsqueda de la felicidad. Barcelona: Alienta.

Ben-Shahar, T. (2014). Elige la vida que quieres. Barcelona: Alienta.

Ben-Shahar, T. (2018). Ser felizes decisión tuya. Barcelona: Alienta.

Beorlegui, C. (2003). Antropología filosófica. Bilbao: Universidad de Deusto.

Berg, L. (1964). Ética social. Madrid: Rialp.

Cabanas, E. y Illouz, E. (2019). Happycracia. Bogotá: Paidós.

Cárdenas, C. y Guarín, É. (2006). Filosofía y teoría del derecho. Bogotá: USTA.

Cardona, C. (1973). Metafísica de la opción fundamental. Madrid: Rialp.

Castells, M. (2010). Globalización e identidad. Quaderns de la Meditarrania, 254-262.

Collins, F. (2008). Cómo habla Dios. La evidencia cientifica de la fe. Bogotá: Planeta.

Congreso de la República de Colombia. (1981). Ley 23.

Consejo Pontificio para la Pastoral de los Agentes Sanitarios. (115). Carta a los agentes sanitarios.

Corte Constitucional Colombiana. (1993). Sentencia C-542.

Corte Constitucional Colombiana. (1993). Sentencia T-493.

Corte Constitucional Colombiana. (1994). Sentencia T-278.

Corte Constitucional Colombiana. (1994). Sentencia T-4ll.

Corte Constitucional Colombiana. (1995). Sentencia T-060.

Corte Constitucional Colombiana. (1997). Sentencia C-239.

Corte Constitucional Colombiana. (1999). Sentencia T-823.

Corte-Constitucional Colombiana. (2001). Sentencia T-970.

Corte Constitucional Colombiana. (2002). Sentencia T-881.

Corte Constitucional Colombiana. (2006). Sentencia C-355.

Corte Constitucional Colombiana. (2013). Sentencia T-673.

Corte Constitucional Colombiana. (2014). Sentencia T-970. 
Édgar Antonio Guarín Ramírez y María Cristina Romero-Sierra

Corte Constitucional Colombiana. (2015). Sentencia C-143.

Corte Constitucional Colombiana. (2016). Sentencia T-291.

Corte Constitucional Colombiana. (2016). Sentencia T-622.

Corte Constitucional Colombiana. (2017). Sentencia T-544.

Corte Constitucional Colombiana. (2017). Sentencia C-147.

Corte Constitucional Colombiana. (2018). Sentencia T-384.

Corte Constitucional Colombiana. (2019). Sentencia T-319.

D’Agostino, F. (2002). Bioética y derecho. Cuadernos de Bioética, l (2), 96-106. http://aebioetica.org/revistas/1994/1-2/17-18/96.pdf

Echavarría, M. (2002). La primacía del amor: una introducción a la ética de Tomás de Aquino. Madrid: Palabra.

Finnis, J. (2000). Ley natural y derecho natural. Buenos Aires: Abeledo Perrot.

Fonnegra, I. (2006). Morir bien. Bogotá: Planeta.

Frankl, V. (1991). El hombre en busca de sentido. Barcelona: Herder.

Fromm, E. (1986). Ética y psicoanálisis. Ciudad de México: Fondo de Cultura Económica.

García-Estébanez, E. (1990). La virtud de la justicia, introducción a las cuestiones 57 a 60 de la Suma Teológica. En T. Aquino, Suma Teológica (pp. 457-469). Madrid: Biblioteca de Autores Cristianos (BAC).

Gevaert, J. (1987). El problema del hombre. Salamanca: Sígueme.

Gilson, E. (1963). El realismo metódico. Madrid: Rialp.

Guarín, É.-A. (2013). Persona y realización efectiva de los derechos. Iusta, 1(38), 133-134.

Guarín, É.-A. (2016). La libertad de los jueces para fallar en positivo. Bogotá: Ibáñez-Universidad Santo Tomás. Heidegger, M. (2012). Sery tiempo. Madrid: Trotta.

Hernández, C. (2000). Bajo capital social. En Colombia un país por construir. Bogotá: Universidad Nacional de Colombia.

Hernández-Sampieri, R., Fernández, C. y Baptista, P. (2014). Metodología de la investigación. Ciudad de México: McGraw Hill.

Herranz, G. (2004). La metamorfosis del activismo pro eutanasia. Persona y Bioética (22), 16-21. personaybioetica.unisabana.edu.co/index.php/personaybioetica/article/view/894

Hervada, J. (2000). Introducción crítica al derecho natural. Bogotá: Temis-Universidad de la Sabana.

Hervada, J. (2000a). Lecciones propedéuticas de filosofía del derecho. Pamplona: Eunsa.

Horta, E. (2009). Más derecho y menos justicia: reflexiones en torno a una aproximación hacia lo jurídico como relación real desde la experiencia de lo percibido. Iusta (31), 28-4l. 
Justicia y felicidad: un análisis de su relación desde el denominado "derecho a morir dignamente"

Horta, E. y Guarín, É.-A. (2018). La justicia como relación real. En Édgar Antonio Guarín Ramírez, Derecho penal, pazy posconflicto (pp. 99-137). Bogotá: Nueva Jurídica.

Hoyos, I. (1999). Las paradojas de una sentencia que enfrenta la dignidad humana con la estimación relativa de lo digno. Pensamiento y Cultura (2), 269-289.

Kant, E. (1983). Fundamentación de la metafísica de las costumbres. Madrid: Espasa-Calpe.

Kaufmann, A. (1999). Filosofía del derecho. Bogotá: Universidad Externado de Colombia.

López-Casquete, M., Muñiz-Velásquez, J. y Gómez-Baya, D. (2018). Materialismo consumista e infelicidad: una revisión bibliográfica. Arbor, 194 (788).

Lorca-Martín-de-Villodres, M.-I. (2013). Felicidad y constitucionalismo. Revista de Derecho Político (88), 123-336.

Melendo, T. y Millán-Puelles, A. (1996). Dignidad iuna palabra vacía? Pamplona: Eunsa.

Merchán-Price, J. (2008). La eutanasia no es un acto médico. Persona y Bioética, 12, 42-52. http://www. scielo.org.co/scielo.php?script=sci_arttext\&pid=S0123-31222008000100005\& $\operatorname{lng}=$ =n\& $\& n r m=i s o$

Millán-Puelles, A. (1976). Sobre el hombre y la sociedad. Madrid: Rialp.

Millán-Puelles, A. (1984). Léxico filosófico. Madrid: Rialp.

Ministerio de Salud. (2018). Resolución 825. Reglamentación del Derecho a Morir Dignamente de los niños, niñas y adolescentes.

Ministerio de Salud y Protección Social. (2015). Resolución 1216.

Moguillansky, M. (2011). Globalización, cultura y sociedad. Andamios, 323-344.

Molina, F. (2015). Felicidad: lecciones de una nueva ciencia. Sociologías, 17 (40), 416-425.

Nogueira-Alcalá, H. (2009). Consideraciones sobre poder constituyen y reforma de la constitución en la teoría y la práctica constitucional. Ius et Praxis, 15, 229-262.

Pieper, J. (2001). Las virtudes fundamentales. Madrid: Rialp.

Platón. (1980). El Protágoras. Oviedo: Pentalfa Ediciones.

Platón. (1988). La república. Madrid: Gredos.

Pulido-Acosta, F. y Herrera-Clavero, F. (2018). Relaciones entre felicidad, inteligencia emocional y factores sociodemográficos en secundaria. Anuario de Psicología, 48, 34-42.

Rancichi, A.-M. y Gelpi, R.-J. (1998). Análisis de los principios éticos en juramentos médicos utilizados en las facultades de medicina de la Argentina en relación con al hipocrático. Medicina, 58, 147-152.

Rodríguez-Adrados, F. (1980). La lexicografía griega y el diccionario griego-español. Madrid: Instituto de Filología del CSIC. 
Édgar Antonio Guarín Ramírez y María Cristina Romero-Sierra

Rodríguez-Hernández, G. (2019). The eudemonic and hedonic role of happiness in a population with high levels of life satisfaction/El rol eudemónico y hedónico de la felicidad en una población con altos niveles de satisfacción con la vida. International Journal of Social Psychology, 230-255.

Rogers, C. (1980). El poder de la persona. Ciudad de México: El Manual Moderno.

Sánchez-Torres, F. (2018, 3 de septiembre). Por objeción de conciencia aumentan pacientes que esperan eutanasia. (R. radio, entrevistador).

Schwartz, S., Luyckx, K. y Vignoles, V. (2011). Handbook of identity theory and research, e-book. Springer.

Sgreccia, E. (2009). Manual de bioética. Madrid: Biblioteca de Autores Cristianos (BAC).

Vattimo, G. (1983). Elpensamiento débil. España: Cátedra.

Zabalza-Iriarte, J. (1993). El derecho objetivo del 25\%. Bogotá: Universidad Santo Tomás. 



\title{
7 \\ Felicidad y procreación. Reflexiones sobre la maternidad subrogada y la infertilidad
}

\author{
Viviana Reyes-Velandia, Lina María Camelo-CÁrdenas, \\ Claudia Karolina GonzÁlez-Cabrera, Camila Ivanna Rodríguez-Paz \\ y SONIA VANessa POVEDA-SANDOVAL* \\ Diana Constanza Nossa-Ramos** y AlejandRo Castaño-Bedoya**
}

Cuando ni la ciencia ni la biotecnología saben dar razón del ser del hombre, tal ciencia y tal biotecnología corren el cercano riesgo de lesionarlo o al menos de tratarlo como no merece, de cosificarlo. Gamboa (2015, p. 41)

\section{Resumen}

El semillero de investigación Educación, Mujer y Familia del Departamento de Humanidades, tiene como objetivo principal profundizar en el debate antropológico, bioético y sociocultural de realidades que se relacionan con la mujer, la familia y

\footnotetext{
* Las autoras son estudiantes y egresadas de las facultades de Psicología y Derecho de la Universidad Católica de Colombia y están vinculadas en el semillero adscrito al grupo de investigación Philosophia Personae. Agradecemos a otros estudiantes que con sus investigaciones han contribuido al desarrollo del trabajo que se presenta, como Eduardo Caycedo, Diana Erazo, Nasly Monroy, Jefferson Rodríguez, de la Facultad de Derecho y a la egresada de la Facultad de Psicología, Liz Malena Bustos Navarro.

** Abogada de la Universidad Católica de Colombia, magíster en Bioética de la Universidad Católica de Ávila, España. Docente y líder del semillero Educación, Mujer y Familia del Departamento de Humanidades, vinculado al grupo de investigación Philosophia Personae de la Universidad Católica de Colombia. denossa@ucatolica.edu.co https://orcid.org/0000-0002-8600-9473

*** Ph. D. y doctor canónico en Filosofía, magíster de la Universidad del País Vasco. Miembro de la Academia Nacional de Medicina Bioética, Miembro de la Red internacional de Bioderecho (Estados Unidos). Investigador del grupo Phronesis de la Universidad Católica de Colombia. acastano@ucatolica.edu.co https://orcid.org/0000-0001-7327-9098
} 
la educación. Una de esas discusiones, en el ámbito nacional e internacional, es el relacionado con las madres de alquiler y el análisis de las principales causas que originan su práctica. Aunque existen numerosos autores que describen su posible regulación o no en el ámbito legal, el tema de la felicidad que proporcionan la maternidad o la paternidad es una de las principales motivaciones para recurrir a esta técnica de reproducción. De esta realidad surge la pregunta de si existe el seguimiento adecuado y la oferta de respuestas posibles a las parejas que atraviesan por una situación de infertilidad o esterilidad. De este modo, gracias a la interdisciplinariedad del semillero, la formación compartida con el semillero de Bioética y Persona Humana de la Universidad Santo Tomás ${ }^{1}$ y el acompañamiento de los coautores del proyecto Religión y Sociedad ${ }^{2}$, se comparten algunos resultados y propuestas del desarrollo de la investigación, como son la reciente legislación y jurisprudencia sobre infertilidad en Colombia, una mirada en el ámbito psicológico y la enunciación de otras propuestas que pueden desarrollarse en futuras investigaciones.

Palabras clave: maternidad subrogada, adopción, felicidad, infertilidad, esterilidad, duelo.

\section{Introducción}

Hace algún tiempo los medios de comunicación han presentado la maternidad subrogada como una posibilidad para suplir un anhelo de los seres humanos: el de ser padre o madre, solo o con pareja. De ello dan muestra varios personajes famosos que han recurrido a esta técnica de reproducción como Cristiano Ronaldo, Ricky Martin, Miguel Bosé, Kim Kardashian y James Rodríguez, entre otros. El asunto se plantea sencillamente como algo de tipo contractual: una mujer que a cambio de dinero le proporciona un hijo a alguien que puede pagar por ello.

Parece que en estos casos el debate mediático se centra en quién es la madre biológica o quién aporta el óvulo para concebir al bebé gestado; cuánto cuesta la

1 Semillero liderado por el doctor Alejandro Castaño-Bedoya.

2 El proyecto de investigación Religión y Sociedad es dirigido por el doctor Víctor Martin-Fiorino, quien lidera el grupo Philosophia Personae del Departamento de Humanidades. 
madre de alquiler, dónde vive, etc. Pero, quizá, el hecho genera un poco más de alarma cuando se presentan noticias como una de mayo de 2020: en diarios internaciones se dio a conocer que, debido al COVID-19, 35 bebés - de 100 nacidos en Ucrania por maternidad subrogada-, se encontraban en el cuarto de un hotel de Kiev a la espera de la apertura de fronteras para que los padres comitentes - que son los contratantes - pudieran recogerlos (BBC News Mundo, 2020).

En atención a lo anterior se considera que esta situación no puede tratarse de manera frívola; en primer lugar, porque se comprende que la maternidad subrogada contiene aspectos que inciden de manera profunda en la esencia de la persona y su felicidad. Y, en segundo lugar, porque este método de reproducción conlleva unas consecuencias en el campo ético, biológico, legal, social y psicológico, que deben ser analizadas de manera crítica (Jouve, 2018).

Al respecto, algunos filósofos desde Aristóteles, “[...] han puesto énfasis en el hecho (o en todo caso, en lo que creemos que es el hecho) de que por medio de nuestras acciones no solo alteramos estados en el mundo externo" (Castaño-Bedoya, 201l, p. 341), sino que configuramos un carácter determinado.

La presente investigación desarrolló un análisis documental que comprendió el empleo de la expresión maternidad subrogada en libros electrónicos, revistas y te$\mathrm{sis}^{3}$. De este tema se encontraron varios artículos relacionados con su tratamiento legal y regulación a nivel internacional. Posteriormente, con la misma técnica de investigación y en las bases de datos nacionales e internacionales se indagó sobre la maternidad subrogada en Colombia.

Seleccionada, revisada y analizada la información, se puso en evidencia que una de las causas de la maternidad subrogada surge por el tema de infertilidad o esterilidad. De este modo, se planteó la inquietud sobre la existencia de acompañamiento profesional a las parejas que pasan por esta condición. Otra pregunta fue si existía en Colombia una regulación o jurisprudencia sobre el tema, si es considerado un asunto de salud pública y cómo se maneja actualmente. 
Este último es, entonces, el objetivo de la investigación y se considera que por la vigencia y la actualidad del tema brinda un aporte de nuevo conocimiento. Contribuye al campo de la bioética y del derecho, resaltando el concepto de persona como unidad sustancial, poseedora de una dignidad que la enaltece y prohíbe cualquier caso de instrumentalización (Villa, 2010 citada por Jouve, 2018).

\section{La maternidad subrogada}

Se considera que la maternidad y la paternidad pueden vivirse desde dos puntos de vista. Primero, se entiende al hijo como un don, un regalo que se acoge; o, por el contrario, un hijo es un deseo que también puede exigirse como un derecho. Ante esta segunda postura, la tecnología muestra que existen diferentes propuestas para lograrlo, como los métodos de fecundación artificial hasta la maternidad subrogada.

Esta última consiste en que una mujer queda embarazada y gesta un bebé para otras personas que, por alguna situación, no pueden hacerlo por sí mismas. Ese bebé puede ser fruto del óvulo y el espermatozoide de los padres, conservando la herencia genética de los dos progenitores (subrogación gestacional) o, bien, puede obtenerse del óvulo de la madre sustituta con los espermatozoides del padre biológico o de un donante (denominada tradicional). Esta gestación puede ser de tipo altruista o lucrativa, dependiendo de la existencia de remuneración o no a la madre gestacional (Agencia Española de Gestación Subrogada, s. f.).

La primera subrogación legal de tipo tradicional se presentó en Estados Unidos en el año 1976, cuando el abogado Noel Keane y el médico Warren Ringold, crearon la agencia Surrogate Family Service. En este lugar, algunas mujeres se ofrecían a gestar bebés para las familias que no podían tener hijos, mediante la técnica de inseminación artificial (Bartolini, Pérez y Rodríguez, 2014). Debido a estas prácticas, al abogado Keane se le atribuye y acuña el término de maternidad subrogada y gestación altruista (Bartolini, Pérez y Rodríguez, 2014).

En la década de 1980 se conoció a nivel internacional el caso de Baby M, en el cual, Elizabeth, la madre sustituta, recibió 10.000 dólares por la gestación de un niño 
para el señor Stern y su esposa; el contrato contemplaba la inseminación artificial, la renuncia filiatoria y el certificado de nacimiento como hijo del señor Stern (Ávila, 2017). Sin embargo, cuando nació la niña, en 1986, Elizabeth y su esposo no hicieron entrega de la menor, lo que llevó la situación a un plano judicial. El Tribunal Supremo de Nueva Jersey, aunque no validó el contrato, concedió la custodia a los señores Stern, en atención al derecho de la menor, pues ellos le podían brindar un mejor ambiente. La madre sustituta solamente tendría derecho a visitas periódicas (Ávila, 2017).

De la subrogación gestacional (óvulo y esperma de los padres), el primer caso se presentó en Estados Unidos entre los años 1985 y 1986, cuando una mujer con histerectomía contrató a una madre sustituta para tener un niño. Y en 1989 nació en Inglaterra otro niño mediante gestación altruista (Aznar y Tudela, 2018).

\section{Regulación}

Existen varias maneras de clasificar la regulación de la maternidad subrogada en el mundo. Están los países que la prohíben, los que la aceptan de modo altruista y los que la admiten de manera amplia (Ávila, 2017).

Vale la pena citar que el Parlamento Europeo, en el año 2015, rechazó la maternidad subrogada como método de reproducción al considerar que atenta contra la dignidad de la mujer. En 2016, el Consejo de Europa prohibió la posibilidad de reglamentarla en toda la Unión Europea (Lázaro, 2019). En consecuencia, el primer grupo de países que la prohibió fue Alemania, Austria, España, Francia, Italia y Suiza. Otros países fuera de la Unión Europea que no permiten su práctica son Arabia Saudita, China, Japón, Pakistán y Turquía. En Estados Unidos, los estados de Dakota del Norte, Nueva York, Columbia, Michigan e Indiana, tienen una prohibición expresa (Aznar y Tudela, 2018).

En otros países como Reino Unido (desde 1985), Grecia (2002), Brasil (2015) y Portugal (2016) está regulada de manera altruista (Albert, 2018). Sin embargo, en Grecia se contempla la posibilidad de compensación a la gestante (Salgado y Salvador, 2019). Y, en Canadá, se prevé el costo de "[...] tratamiento reproductivo, 
que oscila entre $8.000 €$ y $15.000 €$ o en USD entre 9.000 y 18.000 , los gastos de abogados, agencia, seguros, etc." (Rodrigo, 2019).

Los países que permiten la maternidad subrogada de manera amplia son Georgia, Rusia y Ucrania; los estados de Sinaloa y Tabasco en México. Existen otros países que no tienen una legislación que la prohíba o admita, como en el caso colombiano.

\section{Maternidad subrogada en Colombia}

En la Sentencia T-968, la Corte Constitucional mencionó que: "La doctrina ha llegado a considerar la maternidad sustituta o subrogada como un mecanismo positivo para resolver los problemas de infertilidad de las parejas, $y$ ha puesto de manifiesto la necesidad urgente de regular la materia [...]" (Corte Constitucional, 2009). Sin embargo, se evidencia que la Corte no contempló otras fuentes doctrinales como las relacionadas por Marta Albert (2018), Nicolás Jouve (2018), Antonio Casciano (2018), Mónica Bascuñana (2018), entre otros, que, a diferencia de esta posición, advierten las graves consecuencias a nivel social, psicológico, jurídico y ético puede tener la maternidad subrogada.

Continuando con la sentencia en referencia, la Corte advirtió que la regulación sobre la maternidad subrogada debe contener los siguientes requisitos:

1. Que la mujer contratante no pueda concebir.

2. Queserealiceuna subrogacióngestacional(cigotodelos padrescontratantes).

3. Que sea altruista, sin interés económico por parte de la gestante.

4. Que la gestante cumpla con requisitos como mayoría de edad, tenga buena condición de salud psicológica y física y que ya haya tenido hijos.

5. Que la gestante se someta a exámenes físicos y psicológicos previos, durante y después del embarazo.

6. Que se preserve la identidad de las partes. 
7. Que una vez firmado el consentimiento informado y trasplantado el cigoto, no se retracte de la entrega del menor.

8. Que los padres biológicos no rechacen al hijo bajo ninguna circunstancia.

9. Que la muerte de los padres biológicos antes del nacimiento no deje desprotegido al menor.

10. Que, en caso de aborto, la gestante tenga prescripción médica (Sentencia T-968 de 2009).

En este mismo sentido indicó que, en el momento de realizar el contrato de gestación subrogada, se deben tener en cuenta varias condiciones con el fin de garantizar que los padres biológicos del menor sean los donantes de los óvulos y espermatozoides, es decir, lo que se busca es que la madre sustituta no tenga material genético con el nasciturus y, de esta manera, se les otorguen a los contratantes los derechos constitutivos de una relación filial.

En lo que tiene que ver con la propuesta de la Corte Constitucional para legislar sobre el tema de la maternidad subrogada, en Colombia se han presentado varias iniciativas. Por ejemplo, el Proyecto de ley 037 de 2009, por medio del cual se establecieron procedimientos para permitir en todo el territorio nacional la práctica de la gestación sustitutiva mediante las técnicas de reproducción humana asistida ${ }^{4}$. El proyecto no fue aprobado.

En 2016 se presentó un nuevo Proyecto de ley ordinaria con el número 202 ante la Cámara de Representantes del Congreso, que pretendía prohibir la práctica de la maternidad subrogada al ser una categoría de trata de personas y explotación de la mujer con fines reproductivos. El proyecto fue archivado el 21 de junio de 2016, según lo dispuesto en el artículo 190 de la Ley 5 de 1992.

4 Gamboa (2015) realiza unas críticas a este Proyecto de Ley 037 de 2009, al considerar que no diferencia la esterilidad de la infertilidad. Además, citando Rodríguez-Luño, menciona: "las técnicas de reproducción humana asistida no son una ayuda profesional al acto conyugal, sino una sustitución para crear un ser humano" (p. 45). Advierte que tampoco tiene en cuenta las consecuencias médicas y éticas de la fecundación artificial, ni contempla la adopción. Otro aspecto es el tema de la filiación y la estabilidad familiar, la custodia y las consecuencias psicológicas que no son tratados en la propuesta de ley. 
Posteriormente, se presentó el Proyecto de ley estatutaria 186 de 2017, para prohibir la maternidad subrogada con fines lucrativos y crear controles para prevenir esta práctica; pero fue retirado en abril de 2018, como quiera que el Consejo Superior de Política Criminal consideró que no existían — similar que en 2016-, fundamentos empíricos para analizar la propuesta.

Actualmente, cursa el Proyecto de ley estatutaria 118 de 2019 en el Senado, que busca prohibir la maternidad subrogada con fines de lucro y establecer los parámetros generales para la práctica de la maternidad subrogada con fines altruistas. A la fecha, el proyecto se encuentra pendiente de discutir en primer debate del Senado (Congreso de la República de Colombia, Senado, proyectos de ley 2018-2022).

\section{Infertilidad-esterilidad}

Al indagar por las causas de la maternidad subrogada, se puede observar que en un principio se dio por situaciones de infertilidad en la pareja (Jouve, 2017). Sin embargo, en la práctica actual se da en mujeres solas o con pareja; solteros, estériles o no; parejas heterosexuales u homosexuales. Hay casos en que una mujer no quiere gestar un bebé por estética, debido a los cambios en su cuerpo que puede tener el embarazo; por razones laborales; por cuestiones genéticas que puedan perjudicar el feto; o porque las parejas tienen embriones congelados (Ávila, 2017).

Cuando se analiza el tema de la infertilidad de la pareja, también requisito propuesto por la Corte Constitucional, surgen varias preguntas: iexiste un acompañamiento a las parejas y a las familias infértiles? ¿Esterilidad e infertilidad son lo mismo? ¿En Colombia existe alguna legislación al respecto? ¿Qué propuestas distintas a la reproducción asistida y a las madres de alquiler existen actualmente para quienes enfrentan en su vida una situación de infertilidad?

Para la Organización Mundial de la Salud la infertilidad es considerada una enfermedad del sistema reproductivo, que se refleja en la incapacidad de lograr un embarazo después de un año o más de relaciones sexuales sin utilizar ningún método de planificación. Aunado a lo anterior, la infertilidad también se entiende 
como la incapacidad de llevar un embarazo a término, es decir, se da la concepción, pero no se concluye el proceso de gestación (Gamboa, 2015). La esterilidad en cambio es: "la incapacidad total para la reproducción, en el varón para fecundar, en la mujer para concebir o de la pareja para lograr una gestación por incompatibilidad" (Gamboa, 2015, p. 44).

Las causas de esterilidad e infertilidad pueden ser variadas: en las mujeres se presentan alteraciones del cuerpo que impiden el recorrido de los espermatozoides al óvulo, las endometriosis sintomáticas o asintomáticas, alteraciones en las trompas de Falopio, la tendencia a posponer los embarazos después de los 35 años, disfunción hormonal y otras de tipo emocional y psicológico como el estrés ${ }^{5}$. En los hombres también pueden presentarse afectaciones hormonales, afectaciones en los testículos, algunas veces por enfermedades de transmisión sexual, ausencia o exceso de esperma, enfermedades que impiden la eyaculación, o aspectos externos como alcohol, drogas, toxinas (Edwards, 2012, entrevista a María Luisa di Pietro).

\section{El acompañamiento psicológico}

En lo que tiene que ver con esta dimensión, la infertilidad y la esterilidad pueden tener un impacto a nivel individual y de pareja. En ocasiones, se considera una crisis vital que afecta el equilibrio emocional y que se incrementa, además, por el no poder concebir un hijo de forma natural; esto genera un gran desgaste mental pues constantemente se repite un ciclo de esperanza que termina siendo ilusorio.

En muchos casos, la sociedad acompaña a quien pasa por un proceso de duelo por la pérdida de un ser querido o de algo significativo, pero con la infertilidad es diferente, ya que lo que se pierde es algo que nunca existió y el núcleo más cercano

5 Para Díaz (2015) “[...] cada vez comienzan a ser más evidentes las complejas relaciones existentes entre los factores psicológicos y la fertilidad. El estrés empieza a ser reconocido en la bibliografía científica como un factor que en algunas ocasiones puede influir negativamente en la capacidad reproductiva de los seres humanos, hasta el punto de que probablemente puede convertirse en determinante como elemento mediador en el caso de al menos el 5\% de los problemas de esterilidad de origen desconocido" (p. 106). 
a la pareja, como son los padres y amigos, a veces desconocen que la persona infértil está pasando por una crisis vital.

La infertilidad es una pérdida que implica un desgaste económico y psicológico. Las parejas invierten tiempo y recursos económicos, físicos y emocionales en tratamientos reproductivos, que les generan dolor físico y la constante invasión a la privacidad de su vida sexual. Los sentimientos de desesperanza, tristeza, ansiedad y confusión se relacionan con la infertilidad. Algunos estudios revelan que las alteraciones emocionales pueden ser: "sentimientos de inadecuación, desesperación, pena, envidia y celos hacia la mujer embarazada, miedo, pérdida de la libido, impotencia, inestabilidad emocional, pérdida de la autoestima, culpa, depresión e ideación suicida" (Palacios y Jadresic, 2000).

En la infertilidad también se lleva un duelo que, en muchas ocasiones, no es elaborado adecuadamente. El duelo puede entenderse como un proceso en el que la persona acepta la pérdida de alguien o la pérdida de algo que era muy deseado o querido ${ }^{6}$. En los casos de infertilidad y esterilidad es importante acompañar el proceso para que la persona pueda reconocer el dolor de no poder concebir y recuperar una imagen corporal sana de sí misma. Así, cuando un hombre o mujer no logran conseguir esa tan anhelada paternidad o maternidad, deben pasar por "un proceso doloroso que genera emociones similares a las observadas en cualquier duelo, pero donde 'lo perdido' no es algo que alguna vez se tuvo" (Iacobelli, Martínez, Correa, Castro, Yunis y Vlastelica, 2018).

Otro factor importante es la sociedad y el núcleo más cercano a la pareja, o a la persona que tiene el deseo de ser madre o padre. Muchas veces su propia familia está recordándoles el hecho de no haber tenido hijos. Por lo tanto, no existe el apoyo psicológico necesario para poder resignificar la situación de infertilidad y esterilidad, pues el deseo de convertirse en madre o padre puede configurarse en un proyecto de vida biológico, psicológico y social. 
Sin lugar a dudas, el hecho de no poder tener hijos en el momento en el que se tiene el deseo de ser padres causa cierta frustración y sorpresa, y altera la proyección de la persona. También implica la toma de decisiones y la reconfiguración para asumir el nuevo proceso vital. Esto lo confirma Díaz (2015) al señalar que "cuando una persona se encuentra con dificultad para procrear sufre una herida al ego, en el sentido de no poder realizar un deseo, que está interiorizado por naturaleza y socialmente" (p. 105).

La infertilidad es una eventualidad que es difícil de aceptar, por esto, el acompañamiento profesional puede orientarse a que las parejas y personas que quieren ser padres y madres sepan diferenciar entre deseo y demanda, pues para Díaz (2015) “[...] la demanda puede estar influida por muchos factores, como presiones sociales, biomédicos o utilizar los recursos de la tecnología a la mano hoy día [...]" (p. 106).

\section{Acompañamiento legal}

En el Congreso de la República de Colombia han cursado distintos proyectos de ley de iniciativa parlamentaria encaminados al reconocimiento de la infertilidad como una enfermedad, y a su vez, la inclusión de su tratamiento en el Plan Obligatorio de Salud ${ }^{7}$. Finalmente, se promulgó la Ley 1953 del 20 de febrero de 2019, por medio de la cual se establecen los lineamientos para el desarrollo de la política pública de prevención de la infertilidad y su tratamiento dentro de los parámetros de salud reproductiva. En su artículo 3 ordenó al Ministerio de Salud y Protección Social (MSPS), que creara la política pública sobre infertilidad. El ministerio, dando cumplimiento, profirió la Resolución 0228 del 20 de febrero de 2020, un año después de promulgada la ley.

Para comentar las principales características de la ley en mención se puede afirmar que en Colombia la infertilidad se define como una "enfermedad del sistema reproductivo" que impide lograr un embarazo, pese a intentos, en un periodo 
superior a 12 meses (art. 2). En otros países, como Italia, la infertilidad más que una enfermedad es un problema de salud individual y pública, que debe enfocarse en la prevención (Edwards, 2012) ${ }^{8}$.

El artículo 3 de la ley también manifiesta que la política pública a desarrollar debe contener unos componentes como el investigativo, que plantea el "fomento de la investigación científica, en los sectores públicos y privados, sobre las diversas causas de la infertilidad y los tratamientos que podrían coadyuvar a prevenirla, tratarla y curarla" (Ley 1953 de 2019). Así, la investigación se considera fundamental, de tal modo que se vuelve "[...] una tarea urgente y necesaria porque tal vez sea la piedra angular para salirle al paso a la pléyade de problemas éticos que las técnicas de reproducción asistida (TRA) llevan consigo" (Gamboa, 2015, p. 44).

El componente preventivo ${ }^{9}$ y el educativo ${ }^{10}$ se relacionan con lo expuesto por la endocrinóloga italiana María Luisa di Pietro, quien advierte que la prevención de la infertilidad no se da exclusivamente en la salud física y psicológica, sino que debe contar con la dimensión ética, pues para la autora, la promoción de la salud no es meramente informativa, sino que debe "[...] incentivar que las personas no hagan cosas que vayan en contra de su salud y que tomen opciones que la favorezcan. En eso radica la ética, en que la persona elija actuar de esa manera preventiva de riesgos" (Edwards, 2012).

En lo que tiene que ver con el diagnóstico y el tratamiento oportuno, la ley propone "establecimiento de esquemas de atención, diagnóstico y tratamiento oportuno frente a la patología infertilidad; así como fomento de la formación de

8 Ley italiana 40 de 2004 acerca de Reglas sobre procreación médicamente asistida, publicada en el Boletín Oficial 45 de 24 de febrero de 2004.

9 Busca el desarrollo integral e interdisciplinar de estrategias de promoción y prevención de la infertilidad y las enfermedades asociadas a esta.

10 La educación sexual y reproductiva incluye la información sobre infertilidad y su abordaje terapéutico en temas como: hábitos de vida saludables que actúan como factores protectores de la infertilidad sobreviniente, la relación entre las causas de la infertilidad y otras patologías asociadas, los programas y tratamientos de infertilidad. 
profesionales de la salud en el área de la infertilidad, desde una perspectiva integral" (Ley 1953 de 2019, art. 3).

Y este último, pero no menos importante, es el componente de la adopción que promueve el "establecimiento de lineamientos sociales y legales de priorización que permitan garantizar el derecho a formar una familia a partir de la institución de la adopción a las personas diagnosticadas como infértiles" (Ley 1953 de 2019, art. 3).

La adopción constituye una medida indispensable de protección a la niñez, regulada por la Ley 1098 de 2006. Este componente se orienta a las personas infértiles, para que contemplen la crianza de un niño y adolescente, garantizándoles así (a los menores), el derecho a tener una familia. Albert, citando Talavera (2018), menciona que respecto a la adopción siempre debe primar el interés del menor. Esto para afirmar que no es traslado de deseo a un hijo lo que mueve a la adopción, sino un acto de justicia con un niño o joven que necesita una familia:

[...] ni siquiera en la filiación adoptiva, concebida a imagen de la filiación natural, la voluntad de ser padres ha sido nunca determinante, con toda la trascendencia que reviste en este proceso, ya que el fin último de esa institución es garantizar el interés superior del menor frente a cualquier otro y eso debe basarse en criterios objetivos (proceso de idoneidad) y no en criterios subjetivos o psicológicos, como la voluntad de querer ser padre o madre. (p. 86)

Aunado a lo anterior, la ley ordenó al MSPS reglamentar el acceso a los tratamientos de infertilidad mediante técnicas de reproducción humana asistida o terapias de reproducción asistida (TRA) en el plazo de un año a partir del establecimiento de la política pública de infertilidad. Dicha reglamentación debería hacerse conforme a los lineamientos técnicos para garantizar el derecho con recursos públicos, "bajo el enfoque de derechos sexuales y reproductivos contenidos en el modelo del Plan Decenal de Salud Pública” (Ley 1953 de 2019).

Además de lo anterior, se establecieron los criterios que el MSPS debe tener en cuenta para la reglamentación de los tratamientos de infertilidad mencionados ${ }^{11}$.

11 Para la Corte Constitucional los aspectos a estipular son: "(a) determinar los requisitos de acceso a los tratamientos, entre los cuales se encuentran, "edad, condición de salud de la pareja infértil, números de ciclos de baja o alta complejidad que deban realizarse conforme a la pertinencia médica y condición de salud, capacidad eco- 
Por último, dispuso algunas medidas que faciliten la aplicación de la norma, entre las cuales se encuentran la creación de un registro único en los centros de atención especializada que lleven a cabo tratamientos de fertilidad, por lo cual le otorga al Ministerio de Salud y a la Superintendencia Nacional de Salud la facultad de inspección, vigilancia y control sobre dichas instituciones. También, permitió la conformación de asociaciones público-privadas para garantizar la atención y las condiciones técnicas idóneas para cumplir con los propósitos de la iniciativa legal (art. 6) $)^{12}$.

Por otro lado, la Resolución 228 de 2020 tiene por objeto establecer los lineamientos que permitan el desarrollo de una política pública, previniendo la infertilidad y su tratamiento dentro de los parámetros de salud reproductiva. También inició el diseño y formulación de la propuesta de política, convocando a las diferentes direcciones y equipos técnicos de este ministerio, así mismo involucró a la academia, las sociedades científicas y expertos temáticos seleccionados ${ }^{13}$.

En las consideraciones de la resolución se señaló la importancia de la decisión, amparada en el artículo 49 de la Constitución Política, la Ley 1751 de 2015, la Política Nacional de Sexualidad, Derechos Sexuales y Derechos Reproductivos 20142021 y la agenda 2030 de los Objetivos de Desarrollo Sostenible ( 3 y 5). Además, en el anexo de la resolución se trataron los factores de infertilidad asociados a los estilos de vida, elementos ambientales y biológicos.

nómica de la pareja o nivel de Sisbén, frecuencia, tipo de infertilidad", (b) definir los mecanismos de protección individual para garantizar las necesidades en salud; y la infraestructura técnica requerida para la prestación del servicio y (c) establecer los demás criterios que considere necesarios para la aplicación de la ley, en el marco del interés general y la política pública" (art. 4).

12 Para el momento de la investigación aún no se había publicado esta política pública de infertilidad, por lo cual elevamos un derecho de petición ante el Ministerio de Salud y Protección Social, el día 19 de febrero de 2020, bajo el radicado 202042400257372. Se obtuvo respuesta el 3 de marzo de 2020 con el radicado 202021000314501. Dicha respuesta contenía la copia original de la Resolución 228 del 20 de febrero de 2020.

13 Entre el 30 de agosto y el 13 de septiembre de 2019 el proyecto de resolución que adopta la política fue publicado en la página web del ministerio para consulta pública de acuerdo con lo estipulado por el Decreto 1081 de 2015, modificado por el Decreto 1609 del mismo año (rad. 202021000314501, 2020). Posteriormente, inició una fase de análisis y ajuste de acuerdo con las observaciones allegadas, y una vez adelantado este proceso, inició la revisión y aprobación por la Dirección Jurídica del Ministerio de Salud (rad. 202021000314501, 2020), surtida esta etapa, se logró la firma y se expidió con éxito el día jueves 20 de febrero la Resolución 228 de 2020. 
En lo que respecta a los componentes, apenas enunciados en la Ley 1953 de 2019, la resolución expuso de manera más amplia cada uno de ellos. Por ejemplo, en el investigativo señalaron dos líneas de acción: a) la investigación en prevención y tratamiento de la infertilidad y b) la gestión de la información y del conocimiento en prevención y tratamiento para la infertilidad. En el componente educativo se resaltó "la educación integral de la sexualidad", que abarca desde la infancia hasta el adulto joven. El hogar y el colegio "son los escenarios ideales para la promoción de estilo de vida saludables” (MSPS, 2020).

El tercer componente incluyó tres líneas de acción en lo que respecta a la prevención: a) del riesgo asociado a los estilos de vida, b) de las causas asociadas a factores ambientales y c) de las causas asociadas a factores biológicos. El componente relacionado con el diagnóstico y tratamiento oportuno, tuvo en cuenta su realización a partir de la atención primaria en salud.

Los hallazgos de la investigación muestran que este componente descrito en la resolución sí comprende "la intervención de un equipo interdisciplinario con el fin de brindar soporte frente a posibles efectos emocionales, provocados por las formas de asumir la infertilidad y las consecuencias del tratamiento" (MSPS, 2020). Las líneas de acción son: a) integralidad de la atención en salud, que comprende valoración para el diagnóstico y tratamiento de la infertilidad; b) gestión de prestación de servicios a quien se le ha diagnosticado infertilidad. La adopción como último componente de la resolución no es diferente ni profundiza lo señalado en la Ley 1953 de 2019.

Al día siguiente de la resolución expedida por el MSPs, la Corte Constitucional mediante la Sentencia SU074 de 2020 dio a conocer su decisión con lo referente a los tratamientos de infertilidad en Colombia, dando respuesta así a cinco acciones de tutela que fueron analizadas de forma conjunta. En dichos mecanismos de protección se solicitó el amparo de derechos fundamentales a varias mujeres 
infértiles y de escasos recursos, a quienes les fue negada la posibilidad de adelantar tratamientos de fertilización in vitro ${ }^{14}$.

En esta misma sentencia, la Corte afirma que el derecho de acceso a los servicios de salud reproductiva, incluye: a) educación e información sobre todos los métodos anticonceptivos disponibles, acceso a estos; b) acceso al aborto en los casos de despenalización; c) acceso a cuidado obstétrico oportuno, de calidad y libre de violencia; d) prevención y tratamiento de las enfermedades que causan infertilidad; y e) acceso a la tecnología para superar la infertilidad, abierta a las técnicas de reproducción asistida.

En el numeral 159 de la sentencia unificada, la Corte expuso las condiciones y los requisitos necesarios para que una pareja pueda acceder a este beneficio, por parte de su EPS y del Estado colombiano:

a. La persona o pareja que vaya a solicitar el tratamiento debe tener una edad viable que pueda garantizar, al menos en parte, el éxito del tratamiento in vitro.

b. Dicho tratamiento debe ser previamente ordenado por un médico certificado adscrito a la EPS de los solicitantes.

c. El número máximo de intentos que puede sufragarse es de tres ciclos.

d. Certificar la falta de recursos para sufragar el tratamiento, aunque los solicitantes deben realizar un aporte proporcional a sus capacidades económicas.

e. Que no tengan hijos ni se haya practicado un tratamiento de fecundación in vitro previamente.

La Corte finalmente ordenó a la Administradora de los Recursos del Sistema de Seguridad Social (Adres), la creación de un proceso por medio del cual las personas puedan acceder a este tratamiento de forma fácil y rápida. Concluyó su sen-

14 Ya en la Sentencia T-528 de 2014, la Corte había exhortado al Ministerio de Salud y Protección a revisar la situación de personas que enfrentan la infertilidad, pero que no cuentan con recursos para acceder a técnicas de reproducción humana asistida. Además, se solicitó que se iniciara “[...] una discusión pública y abierta de la política pública que incluya en la agenda la posibilidad de ampliar la cobertura del Plan Obligatorio de Salud a dichas técnicas científicas" (Corte Constitucional, 2014). 
tencia sugiriendo al Ministerio de Salud que en el momento de la reglamentación tuviera en cuenta: a) la implementación del sistema de turnos para acceder a las técnicas de reproducción asistida, y b) la estipulación de criterios de priorización como el nivel de afectación de los derechos fundamentales, el orden de las solicitudes, prelación de quienes no han tenido acceso a dichas técnicas, prioridad a los pacientes con mayor edad (Sentencia SU-074 de 2020).

\section{Felicidad e infertilidad, otras propuestas de acompañamiento}

Efectivamente, para algunas personas, el anhelo de vivir su maternidad y paternidad hace parte del proyecto de vida, por ello se entiende que alcanzarlo como se ha soñado brinda felicidad y plenitud. Es necesario comprender todas las implicaciones emocionales y psicosociales que conlleva el no poder desarrollarla cuando se quiere, pero es aún más necesario entender que la vida de un hijo es un don. El deseo de maternidad y paternidad es diferente al derecho a tener un hijo, como quiera que "[...] los deseos de paternidad tienen como límite la dignidad de las personas y la protección de sus derechos fundamentales" (Aznar y Tudela, 2018, p. 102). Los autores comprenden que este deseo no puede llegar a instrumentalizar a las personas, porque "[...] si fuera un derecho exigible llamar a la existencia a otro ser humano, también existiría el derecho contrapuesto a poder quitársela” (Sentencia SU-074 de 2020).

Se considera que llegar a comprender una situación de infertilidad desde ese punto de vista requiere de un acompañamiento psicológico y clínico adecuado. Por esta razón, es relevante la asesoría de profesionales que perciban la infertilidad como incapacidad dolorosa (Edwards, 2012). Pero, además, es necesario contar con profesionales de la salud que, con un buen diagnóstico, identifiquen las causas de la infertilidad que pueden tratarse con procedimientos hormonales, quirúrgicos o desbloqueos emocionales. Esto les permitirá a los pacientes la búsqueda de soluciones que curen directamente la infertilidad.

Ahora bien, en caso de agotar todas las posibilidades o por ejemplo en los casos de esterilidad, un profesional puede acompañar la aceptación de esta situación 
que, como vimos, requiere de un proceso de duelo. Se considera y propone que este acompañamiento no debe asumirlo solamente la pareja, sino su núcleo familiar más cercano. Porque para los familiares de la pareja también debe ser difícil saber y aceptar que no pueden ser abuelos, tíos, etc.

\section{Redes de acompañamiento}

Del rastreo documental se encontraron redes para mujeres infértiles, que ofrecen espacios para hablar de su situación, para resolver preguntas con expertos, brindan grupos de apoyo, tutores emocionales, asesoría jurídica, testimonios y la invitación a participar activamente en la red. Un ejemplo de ellas es la Asociación Red Nacional de Infértiles, que se define como:

Un grupo de mujeres que hemos tenido la suerte de conocernos a través de internet durante nuestra dura lucha contra la infertilidad. Cuando el dolor de la infertilidad nos ha atrapado y no hemos tenido a nadie con quién hablar que nos entendiera, hemos recurrido a la red buscando consuelo y nos hemos encontrado. Y eso nos ha cambiado la vida. Compartir nuestro dolor, pena, angustia, sufrimiento y por qué no, situaciones divertidas, ha hecho que nuestro camino sea muy muy diferente. (s. f.)

En el blog La vida sin hijos, maternidad invisible también se encuentran herramientas y recursos de acompañamiento a la infertilidad, retiros para asumir el duelo, seminarios, libros, un espacio para testimonios e, incluso, experiencias de frustración tras el uso de técnicas de reproducción asistida fallidas. Este blog está vinculado a Gateway Women, la red global de amistad y apoyo para mujeres sin hijos.

Varios testimonios de las páginas mencionadas señalan que la oportunidad de compartir y expresar sus sentimientos les ayudan a asumir sus proyectos de vida y a no sentir que están pasando solas por una situación dolorosa.

Cuando se indagó por la existencia de redes para hombres similares a estas, se encontró que, en estos casos, el tema de la esterilidad no se ha estudiado de manera suficiente. Podría preverse un acompañamiento específico en el componente psicológico, médico e investigativo. A diferencia de las redes para mujeres, los hombres no tienen esos espacios de comunicación, esto puede darse por la di- 
ferencia que existe entre hombres y mujeres para expresar sus sentimientos y emociones, o porque culturalmente es un tema difícil de abordar (Pinto, 2019). Esta visión de la infertilidad en los hombres también puede convertirse en otro campo de estudio y propuesta de investigación.

\section{Maternidad y paternidad espiritual}

El tema de la maternidad y paternidad no existe solamente de manera biológica, hay una dimensión trascendente que se puede denominar espiritual. El humanismo cristiano presenta una amplitud de esa gestación que se manifiesta principalmente en la educación (Jiménez, 2015). También, Benedicto XVI, lo recuerda así:

La Iglesia presta mucha atención al sufrimiento de las parejas con infertilidad, se preocupa por ellas y, precisamente por eso, alienta la investigación médica. Sin embargo, la ciencia no siempre es capaz de responder a los deseos de numerosas parejas. Por eso quiero recordar a los esposos que viven la condición de infertilidad, que su vocación matrimonial no se frustra por esta causa. Los esposos, por su misma vocación bautismal y matrimonial, siempre están llamados a colaborar con Dios en la creación de una humanidad nueva. En efecto, la vocación al amor es vocación a la entrega de sí, y esta es una posibilidad que ninguna condición orgánica puede impedir. Por consiguiente, donde la ciencia no encuentra una respuesta, la respuesta que ilumina viene de Cristo. (2012)

Además, no puede desconocerse el desarrollo de la maternidad y la paternidad espiritual en las personas consagradas que dedican su vida a cuidar, educar, ayudar a "los enfermos, los minusválidos, los abandonados, los huérfanos, los ancianos, los niños, los jóvenes, los encarcelados y, en general, los marginados" (Juan Pablo II, 1988). Incluso, existen personas no consagradas a la vida religiosa que se han dedicado a la formación, al servicio y al cuidado de otros, en ejercicio de esa vocación que no se elimina por el hecho de la imposibilidad de la generación biológica.

\section{Discusión de resultados}

En 1976, en Estados Unidos, se presentó el primer contrato de gestación por subrogación, con el objetivo de ayudar a las parejas que presentaban alguna 
situación de infertilidad. Actualmente, se sigue practicando no solo por esta causa, sino por otras razones de tipo estético, genético, médico, entre otros. La regulación de las madres de alquiler varía según el país: en algunos está ampliamente reglamentada y permitida; en otros, la maternidad subrogada se admite de manera altruista; otro grupo de países la tienen completamente prohibida y, por último, otros en los que no está autorizada ni prohibida por la ley.

En Colombia, la Corte Constitucional en la Sentencia T-968 de 2009 aceptó esta práctica reproductiva y estipuló los requisitos para que pueda llevarse a cabo. Algunas de las condiciones del contrato son la imposibilidad de procrear de los contratantes; la subrogación gestacional, es decir, la carga genética es de la pareja y no de la gestante; el altruismo; la preservación de identidad de las partes; la no retractación de la entrega del menor y la posibilidad del aborto en los casos despenalizados por la misma Corte Constitucional, entre otros. A nivel legislativo, desde 2009 se han presentado distintos proyectos de ley para regularla, sin promulgación hasta la fecha.

Ahora bien, volviendo a las causas de la maternidad subrogada, ya se mencionó que una de ellas es la infertilidad de la pareja. Dicha situación puede considerarse una enfermedad del sistema reproductivo o como un asunto de salud pública, dependiendo la regulación de cada país. La literatura hace distinciones entre la infertilidad, como la incapacidad de llevar a término un embarazo y la esterilidad como la imposibilidad de concebir un bebé.

En el ámbito legal se observa que las tres ramas del poder público han hecho pronunciamientos respecto al tema de la infertilidad, a través de la ley expedida por el Congreso, la resolución del ministerio y la sentencia unificada de la Corte. Pero vale la pena mencionar con Gamboa (2015), que las técnicas de reproducción asistida no son la única opción para parejas que atraviesan por una situación de infertilidad. Di Pietro señala, además, que ante un matrimonio que no logra concebir, es relevante un buen diagnóstico médico, porque como primera opción se ofertan las TRA que no son un tratamiento porque no curan la causa de la 
infertilidad, sino que, "[...] solo sustituyen la capacidad generativa de vida de la pareja" (Edwards, 2012).

Siguiendo este orden, la Ley 1953 de 2019 y la Resolución 228 de 2020, expedida por el MSPS, señalaron varios componentes para prevenir, educar, diagnosticar oportunamente y tratar la infertilidad. Esto porque se entiende que existen modos, condiciones y estilos de vida de las personas que pueden originarla. Por ejemplo, para Di Pietro, la prevención y educación sobre la infertilidad no es una tarea fácil, pero sostiene que debe trabajarse con población joven y universitaria, concienciándola respecto a que "todo lo que se hace contra la propia salud entre los 19 y los 25 años genera problemas en la edad adulta” (Edwards, 2012) ${ }^{15}$.

En cuanto al diagnóstico y tratamiento oportuno de la infertilidad realizado desde la atención primaria en salud, se propone tener un plan integral de cuidado y tratamiento que incluya la intervención de un equipo interdisciplinario con el fin de brindar soporte a los efectos emocionales, provocados por las formas de asumir la infertilidad y su tratamiento, como se mencionó. La investigación en este campo tiene diferentes ámbitos, como por ejemplo la salud psíquica, estilos de vida como alimentación, alcohol, drogas, el efecto de las vacunas, la curación de enfermedades de transmisión sexual, el efecto del uso de anticonceptivos (Edwards, 2012).

Se nota, entonces, que la ley y la resolución del MSPS hacen énfasis en el acompañamiento especializado a quienes atraviesan esta situación, mientras que la Corte Constitucional en la Sentencia 074 de 2020 se centra en los requisitos para acceder a los mecanismos de reproducción asistida.

Otro tema que aborda la Resolución 228 del ministerio es el de la adopción, que propone orientar a las personas infértiles para que reciban la información

15 María Luisa di Pietro señala que las conductas personales y prevenibles que pueden influir en la infertilidad son: "el incremento de las enfermedades de transmisión sexual, que muchas veces son consecuencia de relaciones sexuales precoces o de una vida sexual promiscua. También la utilización de contraceptivos, sobre todo los antiimplantatorios, como la píldora del día después y el DIU —el dispositivo intrauterino- por su acción en el endometrio. Otro factor, sobre todo en los hombres, es el consumo de cigarro, de drogas y alcohol. En ellos también afecta la contaminación ambiental, que es responsabilidad tanto de la persona como de la sociedad" (Edwards, 2012, entrevista a María Luisa di Pietro). 
suficiente "y sean considerados como alternativa para la crianza de un niño o un adolescente" (MSPS, 2020, p. 13), a quien el Estado le debe proteger "el derecho de crecer en el seno de una familia" (MSPS, 2020, p. 13)

En este componente, mientras que la Ley de 2019 y la Resolución 228 de 2020 la enuncian, se observa que la sentencia unificada de la Corte 2020 no hace una propuesta o mención al respecto; así como tampoco le ordena al ministerio regularla dentro de su política pública de prevención. La Corte, en cambio, se limita a exponer los requisitos para acceder a las técnicas y señala propuestas de criterios de priorización.

Ahora bien, cuando se da una situación de infertilidad incurable o se encuentra ante la esterilidad, se entiende como una circunstancia dolorosa que debe ser acompañada por profesionales y que, para hacer un proceso de duelo completo, debería involucrarse al núcleo más cercano de la pareja. También se encuentran varias redes de apoyo a mujeres infértiles que brindan atención, cuidado, herramientas y espacios de comunicación. Mientras tanto, la infertilidad masculina debe desarrollarse en materia de investigación, acompañamiento y cuidado psicológico, pues, por cuestiones culturales es un tema poco mencionado.

La maternidad y paternidad no se agotan en el aspecto biológico; hay una dimensión espiritual que se refleja en el cuidado y educación de quienes están bajo el amparo de otros. Los religiosos, matrimonios o varias personas solteras desarrollan la maternidad y paternidad espiritual a través del servicio. Otros, la desarrollan con la adopción, que es exclusivamente la oportunidad de darle a un menor la familia que merece tener y que le fue negada.

Desde el Magisterio Pontificio, el papa Francisco (2016) en su Exhortación Apostólica Amoris Laetitia, habla de la fecundidad ampliada y pone énfasis en que la adopción es el "camino para realizar la maternidad y la paternidad de una manera muy generosa” (p. 179). El papa continúa diciendo: "[...] quiero alentar a quienes no pueden tener hijos a que sean magnánimos y abran su amor matrimonial para recibir a quienes están privados de un adecuado contexto familiar" (2016, p. 179). 


\section{Conclusión}

Existen diferentes aspectos de la vida humana que, aunque social y legalmente sean permitidos, requieren de un amplio análisis de tipo ético, porque implican a la persona y todas sus dimensiones. Uno de esos ejemplos es la maternidad subrogada, que se da, en algunos casos, por temas de infertilidad de la pareja contratante. Se propone así, que, en el componente investigativo, se continúen esfuerzos por profundizar en el acompanamiento clínico y psicológico a las parejas, a sus núcleos familiares y un tratamiento específico para los hombres infértiles.

En este trabajo se analizó, entonces, la felicidad que puede traer ser padre o madre y, la afectación a todo el proyecto de vida que puede generar el no poder lograrlo. Sin embargo, hay puntos que deben ser investigados en el tema de la felicidad, ya no de los padres comitentes, sino de la otra cara de la moneda: la madre gestante y su entorno familiar.

Por último, el tema de la maternidad subrogada altruista debería abordarse y analizarse desde el derecho comparado, puesto que, en otros países donde se permite este tipo de subrogación, el "turismo reproductivo" es una realidad innegable, muchas veces registrado por las mismas agencias de fertilidad. El altruismo en la maternidad subrogada es otro aspecto que se prevé en las legislaciones y que podría generar graves situaciones jurídicas y sociales en un futuro. Así lo afirma Ignacio Aréchaga: "no se sabe de altruistas europeas ricas que se presten a ser madres subrogadas para una pareja de campesinos indios pobres" (citado por Aznar y Tudela, 2018, p. 105), esto significa que, bajo este altruismo, se esconde una verdadera explotación de la mujer en países con dificultades económicas.

\section{Referencias}

Agencia Española de Gestación Subrogada. (s. f.). ¿Qué es la maternidad subrogada? http://aeges.es/ maternidad-subrogada/

Albert, M. (2018). La maternidad altruista y la maternidad subrogada. En N. Jouve (ed.), La maternidad subrogada. Qué es y cuáles son sus consecuencias (pp. 115-145). Madrid: Sekotia. 
Felicidad y procreación. Reflexiones sobre la maternidad subrogada y la infertilidad

Albert, M. (2018). Distorsión de la maternidad y la paternidad. En Actas del Congreso Internacional. 8-10 de noviembre de 2018. Mayo del 68. I. Una época de cambios, un cambio de época (pp. 79-100). Madrid: Editorial Universidad Francisco de Vitoria.

Ávila, C. (2017). La maternidad subrogada en el derecho comparado. Cadernos de Dereito Actual (6), 313344. http://www.cadernosdedereitoactual.es/ojs/index.php/cadernos/article/view/101/124

Baena, G. M. E. (2017). Metodología de la investigación (3. ․ ed.). Ciudad de México: Grupo Editorial Patria. http://www.biblioteca.cij.gob.mx/Archivos/Materiales_de_consulta/Drogas_de_Abuso/Articulos/ metodologia\%20de\%20la\%20investigacion.pdf

Bartolini, M., Pérez, C. y Rodríguez, A. (2014). Maternidad subrogada: explotación de mujeres con fines reproduc tivos. Ciudad de México: Ediciones Capricho.

BBC News Mundo (2020). Coronavirus. Los bebés nacidos por gestación subrogada varados en un hotel en Ucrania. BBC. https://www.bbc.com/mundo/noticias-internacional-52679424

Benedicto XVI. (2012). Discurso a los participantes en la Asamblea de la Pontificia Academia para la Vida. http://w2.vatican.va/content/benedict-xvi/es/speeches/2012/february/documents/hf_ben-xvi_spe 20120225_acdlife.html

Cabodevilla, I. (2007). Las pérdidas y sus duelos. Anales del Sistema Sanitario de Navarra, 30 (3), 163-176. http://scielo.isciii.es/scielo.php?script=sci_arttext\&pid=S1137-66272007000600012\& $\& \operatorname{lng}=e s \& t \ln =$ es.

Cabrera, L. (2019). El consentimiento libre: la trampa de la explotación femenina en la maternidad subrogada. Revista Chilena de Derecho, 46 (2), 527-553. https://dx.doi.org/10.4067/S0718-3437201 9000200527

Cámara de Representantes. (2017). Proyecto de Ley 186 de 2017. https://www.camara.gov.co/sites/default/files/2017-11/P.L.E.186-2017C\%20\%28MATERNIDAD\%20SUBROGADA\%29.pdf

Castaño, A. (2011). La conducta como elemento configurador en el concepto de derecho. Su ámbito de aplicación como el primer analogado en la filosofía práctica. Díkaion, 20(2). https://dikaion.unisabana.edu.co/index.php/dikaion/article/view/2059

Congreso de la República. (s. f.). Proyectos de ley desde el 2018-2022 n.․118. http://leyes.senado.gov co/proyectos/index.php/proyectos-ley/cuatrenio-2018-2022/2019-2020/article/l18-por-medio-dela-cual-se-prohibe-la-maternidad-subrogada-con-fines-de-lucro-y-se-establecen-los-parametrosgenerales-para-la-practica-de-la-maternidad-subrogada-con-fines-altruistas

Congreso de la República de Colombia. (2019). Ley 1953 de 2019. Por medio de la cual se establecen los lineamientos para el desarrollo de la política pública de prevención de la infertilidad y su tratamiento dentro de los parámetros de salud reproductiva. https://dapre.presidencia.gov.co/normativa/ normativa/LEY\%201953\%20DEL\%2020\%20DE\%20FEBRERO\%20DE\%202019.pdf 
Congreso de la República de Colombia. (s. f.). Proyectos de Ley 107 de 2009 Cámara, 109 de 2013 Cámara y 123 de 2016 Senado, 082 de 2015 Cámara. http://www.senado.gov.co/index.php/az-legislativo/ proyectos-de-ley

Constitución Política de Colombia. (1991). http://www.secretariasenado.gov.co/senado/basedoc/constitucion_politica_1991.html

Corte Constitucional. (2009). Sentencia T-968. https://www.corteconstitucional.gov.co/ relatoria/2009/T-968-09.htm

Corte Constitucional. (2014). Sentencia T- 528. https://www.corteconstitucional.gov.co/ relatoria/2014/t-528-14.htm

Corte Constitucional. (2020). Sentencia SU074. https://www.corteconstitucional.gov.co/relatoria/2020/su074-20.htm

Díaz, N. (2015). Aspectos psicológicos en infertilidad y gestación subrogada. Revista Mexicana de Medicina de la Reproducción, 8(2), 101-129.

Edwards, L. (2012). La infertilidad se puede prevenir. Hacer Familia 194. Entrevista a María Luisa Di Pietro. http://hacerfamilia.cl/2012/11/la-infertilidad-se-puede-prevenir/\#:: :text=De\%20acuerdo\%20 a\%20los\%20datos, de $\% 20$ causas $\% 20$ masculinas $\% 20 y \% 20$ femeninas

Gaceta del Congreso Senado y Cámara. (2019). Proyecto de ley estatutaria número 118 de 2019, por medio de la cual se prohíbe la maternidad subrogada con fines de lucro y se establecen los parámetros generales para la práctica de la maternidad subrogada con fines altruistas. http://www.secretariasenado.gov.co/legibus/legibus/gacetas/2019/GC_0789_2019.pdf

Gamboa, G. (2015). Investigación en fertilidad: una perspectiva bioética. Medicina U. P. B., 34 (1), 40-48. https://www.redalyc.org/pdf/1590/159046025006.pdf

Iacobelli, V., Martínez, A., Correa, C., Castro, M. I., Yunis, Y. y Vlastelica, J. (2018). Adopción y duelo por infertilidad. Un modelo de trabajo. Revista de Familias y Terapias 27, (45) 79-92. https://doi. org/10.29260/DFYT.2018.45D

Jiménez, L. (2015). El genio femenino. En UCAV (ed.), La misión de la mujer: recopilación de textos de Lydia Jiménez y Gerhard L. Müller, en el V Centenario del nacimiento de Santa Teresa de Jesús, doctora de la Iglesia (pp. 11-32). Ávila: Editorial Universidad Católica de Ávila.

Jouve, N. (2017). Perspectivas biomédicas de la maternidad subrogada. Cuadernos de Bioética. Volumen XXVIII (93). 153-162. http://aebioetica.org/revistas/2017/28/93/153.pdf

Jouve, N. (2018). El significado de la maternidad y de la familia. En N. Jouve (ed.), La maternidad subrogada. Qué es y cuáles son sus consecuencias (pp. 11-47). Madrid: Sekotia.

Juan Pablo II. (1988). Mulieris Dignitatem, Carta apostólica sobre la dignidad y la vocación de la mujer con motivo del Año Mariano. 
Felicidad y procreación. Reflexiones sobre la maternidad subrogada y la infertilidad

Lamm, E. (2013). Gestación por sustitución. Ni maternidad subrogada ni alquiler de vientres. Barcelona: Editorial Universitat de Barcelona. http://diposit.ub.edu/dspace/bitstream/2445/115984/1/978844 7537730\%20\%28Creative\%20Commons\%29.pdf

Lázaro, C. (2019). El concepto de persona como elemento clave de la identidad europea. Cuadernos Europeos de Deusto, núm. esp. 02, 89-201. http://ced.revistas.deusto.es/article/viewFile/1555/1897

Palacios, E. y Jadresic, E. (2000). Aspectos emocionales en la infertilidad: una revisión de la literatura reciente. Revista Chilena de Neuropsiquiatría, 38 (2), 94-103. https://dx.doi.org/10.4067/ S0717-92272000000200004

Papa Francisco. (2016). Exhortación Apostólica Amoris Laetitia. Numerales 178-184. http://www.vatican. $\mathrm{va} /$ content/francesco/es/apost_exhortations/documents/papa-francesco_esortazione-ap_20160319_ amoris-laetitia.html

Parlamento Italiano. (2004). Ley 40 del 19 de febrero. Reglas sobre procreación médicamente asistida. http://www.parlamento.it/parlam/leggi/04040l.htm

Pinto, G. (2019). Dejemos de hablar solo de infertilidad femenina: el riesgo entre los hombres ha crecido nueve puntos en una década. El Diario. https://www.eldiario.es/sociedad/fertilidad_masculina-espermatozides-infertilidad-ciencia_0_870713345.html

Rodrigo, A. (2019). Gestación subrogada en Canadá: legislación y precio. https://babygest.com/es/ canada/

Salgado, S. y Salvador, Z. (2019). Gestación subrogada en Grecia: legislación, registro del bebé y precio. https://babygest.com/es/grecia/

Talavera, P. (2017). Maternidad subrogada: ficción jurídica contra verdad biológica. Revista Derecho y Genoma Humano, (46), 218-219.

Valencia, A. (2019). ¿Deberían pagar cárcel quienes practiquen el "alquiler de vientres" en Colombia? https://www.asuntoslegales.com.co/actualidad/deberian-pagar-carcel-quienes-practiquen-el -alquiler-de-vientres-en-colombia-2814576

Villa, M. (2010). La vida humana en la encrucijada. Pensar la bioética. Madrid: Ediciones Encuentro.

\section{Bibliografía}

Bascuñana, M. (2018). Gestación subrogada: aspectos emocionales y psicológicos en la mujer gestante. Dilemata. Revista internacional de Éticas Aplicadas (28), 41-49. https:/www.dilemata.net/revista/index. $\mathrm{php} /$ dilemata/issue/view/29

Cáceres, M. (2018). Legislación comparada sobre gestación subrogada en el continente americano. Biblioteca del Congreso Nacional de Chile. Asesoría Técnica Parlamentaria. https:/obtienearchivo.bcn.cl/obtiene archivo?id=repositorio/10221/26024/1/BCN_gestacion_subrogada.pdf 
Carreño, J., Sánchez, C. y Morales, F. (2016). La psicología y la infertilidad; una experiencia institucional para establecer una línea de investigación. Integración Académica en Psicología, 4 (10), 63-72.

Casciano, A. (2018). La subrogación en la maternidad. fenomenología de una interacción humana despersonalizadora. Cuadernos de Bioética 29 (95), 39-56. http://aebioetica.org/revistas/2018/29/95/39.pdf

García, R. y Herrero, M. (2018). Maternidad subrogada: dilemas éticos y aproximación a sus respuestas jurídicas. Anales de la Cátedra Francisco Suárez 52, 67-89. Doi:10.30827/acfs.v52i0.6551

González, N. y Albornoz, M. (2016). Aspectos transfronterizos de la gestación por sustitución. Anuario Mexicano de Derecho Internacional, 1 (16), 159-187. Doi: http://dx.doi.org/10.22201/ iij.24487872e.2016.16.524

Guerra-Palmero, M. (2017). Contra la llamada gestación subrogada. Derechos humanos y justicia global versus bioética neoliberal. Gaceta Sanitaria, 31 (6), 535-538. https://dx.doi.org/10.1016/j. gaceta.2017.05.009

Pérez, B. y Santos, L. (2019). Gestación subrogada. Ser padres, ¿derecho o deseo?: reportaje en profundidad. (Trabajo fin de grado inédito). Sevilla: Editorial Universidad de Sevilla. https://idus.us.es/ handle/11441/91663 


\section{平 UNIVERSIDAD CATĆLICA \\ de Colombia
Vigilada Mineducación}

Sapientia aedificavit sibi domun

Editado por la Universidad Católica de Colombia en abril de 2021, en tipografías California y American Type,

tamaño 11 pts.

Publicación digital

Hipertexto Ltda.

Bogotá, D. C., Colombia 
El libro analiza la relación entre las personas y la felicidad desde las múltiples dimensiones de la existencia humana. Por la rigurosidad de sus reflexiones, resultado de una ardua investigación, se constituye en un valioso aporte a las diferentes áreas de conocimiento dentro de las humanidades. En el campo educativo, mediante una hermenéutica del ethos y de la gracia, se propone que las universidades católicas reivindiquen las bienaventuranzas como compromiso social radical. Se fundamenta una propuesta político-educativa que desarrolle aquellas capacidades humanas necesarias para construir un proyecto cristiano de vida feliz. Desde la antropología filosófica se presenta a la persona como ser capaz de dotar de sentido su modo de estar en el mundo, más allá de la búsqueda de la propia felicidad. Por otra parte, con un acercamiento ético se aborda el trauma sociocultural que deja la pandemia del COVID-19, rescatando la empatía y la solidaridad como camino de reencuentro con la felicidad. También, en el área de las ciencias históricas se muestra cómo los conceptos de persona y felicidad son relevantes en el pensamiento de Juan xxIII y constituyen un aspecto importante para entender el desarrollo del Magisterio Pontificio y del catolicismo contemporáneo. Por último, desde la bioética y el bioderecho se realiza un aporte novedoso al área de las humanidades, al abordar la relación entre la felicidad y la justicia desde el llamado "derecho a morir dignamente" y el debate sobre la maternidad subrogada.

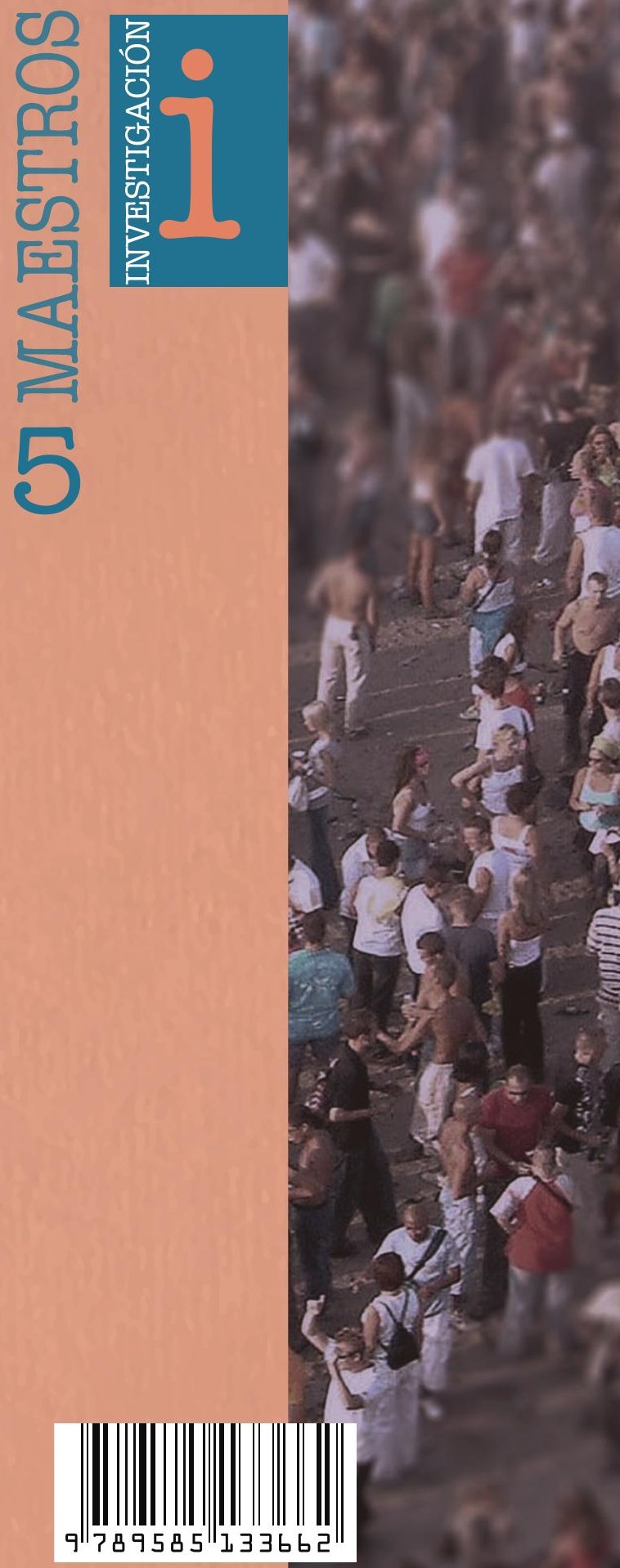

